UNIVERSIDADE DE SÃO PAULO

FACULDADE DE FILOSIFIA LETRAS E CIÊNCIAS HUMANAS

DEPARTAMENTO DE LETRAS MODERNAS

PROGRAMA DE PÓS-GRADUAÇÃO EM LÍNGUA ESPANHOLA E LITERATURAS ESPANHOLA E HISPANO-AMERICANA

Priscila Oliveira Vieira

¿“Español sin fronteras"?

Ou entre as fronteiras projetadas pelo imaginário e pelo real? 
UNIVERSIDADE DE SÃO PAULO

FACULDADE DE FILOSIFIA LETRAS E CIÊNCIAS HUMANAS

DEPARTAMENTO DE LETRAS MODERNAS

PROGRAMA DE PÓS-GRADUAÇÃO EM LÍNGUA ESPANHOLA E LITERATURAS ESPANHOLA E HISPANO-AMERICANA

\title{
¿"Español sin fronteras"? \\ Ou entre as fronteiras projetadas pelo imaginário e pelo real?
}

\begin{abstract}
Priscila Oliveira Vieira
Dissertação apresentada ao Programa de Pós-Graduação em Língua Espanhola e Literaturas Espanhola e Hispano-Americana do Departamento de Letras Modernas da Faculdade de Filosofia, Letras e Ciências Humanas da Universidade de São Paulo, para obtenção do título de Mestre em Língua Espanhola.
\end{abstract}

Área de concentração: Línguas Estrangeiras Modernas - Espanhol Orientadora: Profa. Dra. María Teresa Celada.

SÃO PAULO

2012 


\section{AUTORIZO A REPRODUÇÃO E DIVULGAÇÃO TOTAL OU PARCIAL DESTE TRABALHO, POR QUALQUER MEIO CONVENCIONAL OU ELETRÔNICO, PARA FINS DE ESTUDO E PESQUISA, DESDE QUE CITADA A FONTE.}

Catalogação na Publicação Serviço de Biblioteca e Documentação

Faculdade de Filosofia, Letras e Ciências Humanas da Universidade de São Paulo

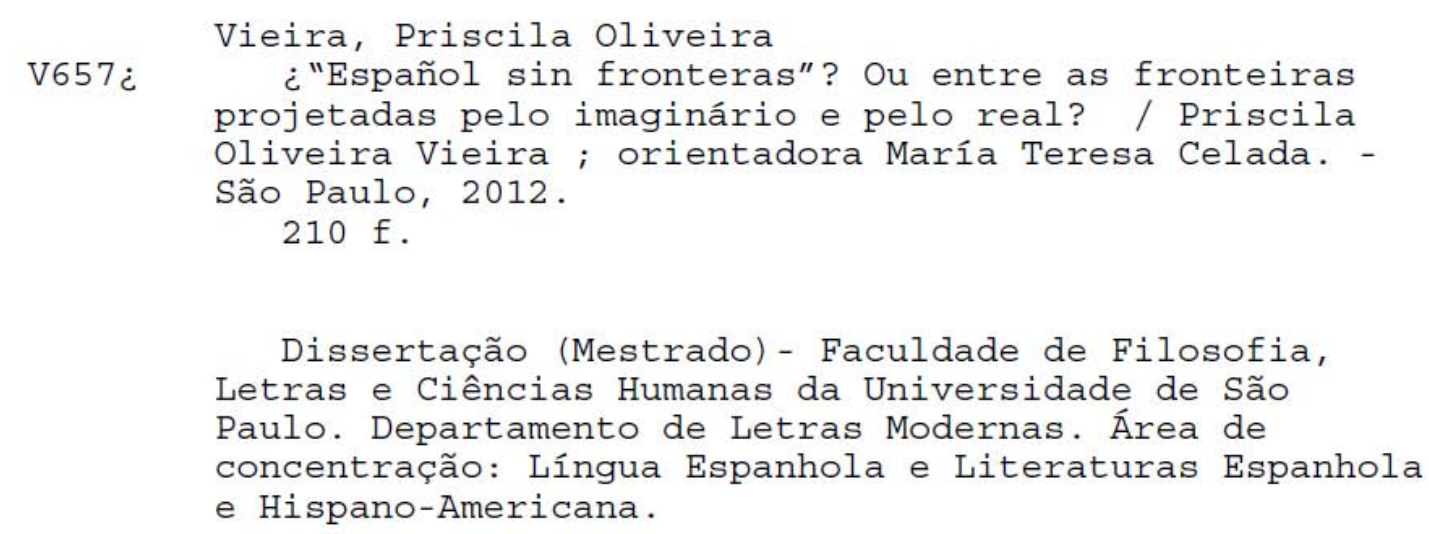

1. CH791.13.1.2.. 2. CH792.7.1.3..3.

CH751.4.20.2.3.. I. Celada, María Teresa, orient. II. Título. 


\section{SUMÁRIO}

$\begin{array}{ll}\text { Introdução } & 12\end{array}$

1. As urgências de nossa prática 12

1.1. Entendendo o nosso mal-estar: como ele irrompe na escola? 13

1.2. À luz da teoria, nosso mal-estar nos sinaliza uma hipótese 17

2. Delimitação de nosso objeto 19

3. Sobre as partes desta dissertação 23

PARTE 1 - Abrindo ARQUIVOS SOBRE O ENSINO DA LE NO BRASIL 26

Capítulo 1 - O arquivo dos documentos jurídicos e a LE na educação brasileira 27

1. Reformas e decretos 29

2. As LDBs de 1961 a 1996

3. A Lei 11.160 de 2005

Capítulo 2 - $\mathrm{O}$ arquivo dos instrumentos linguísticos: a fundação e a mobilização de sentidos para o ensino da LE no Brasil

1. A fundação de uma memória para a LE $\quad 70$

2. A memória sobre a LE e sua inflexão no processo de ensino-aprendizagem 80

2.1. O Manual de Español de Becker

2.2. O Español Básico de Álvarez Calleja $\quad 85$

2.3. O Curso Práctico de Español de Francisco Frigério 92

2.4. A coleção Vamos a Hablar, publicada pela editora Ática 97

3. Rumo a um Español sin fronteras 103

PARTE 2 - COM FOCO EM “ESPAÑOL SIN FRONTERAS” 107

Capítulo 3 - Como se projeta um “Español sin fronteras” em cada edição 108

1. Com foco no título Español sin fronteras 112

1.1. O título e sua dupla determinação 112

1.2. O título como indício 116

2. O título em novas relações de sentido 118

2.1. Primeira edição: Estudar espanhol por quê?/Porque pode despertar o interesse 119

2.1.1. A relação com as capas $\quad 119$

2.1.2. A relação com a apresentação 126

2.1.3. Rumo à $2^{\mathrm{a}}$ edição 134

2.2. Segunda edição: Estudar espanhol por quê?/Porque é uma língua de acesso à cultura de "mundos que nos hermanan" 
2.2.2. A relação com a apresentação 138

2.2.3. Rumo à $3^{\mathrm{a}}$ edição 146

2.3. Terceira edição: Estudar espanhol por quê?/Porque é uma língua veicular no mundo da globalização

2.3.1. A relação com as capas $\quad 147$

2.3.2. A relação com a apresentação 149

Capítulo 4 - "Español" entre "fronteras" 153

1. A apresentação e as condições de produção 155

2.Na materialidade linguística: entre um 'pero' e um 'sino' 156

3. No real: "Español" entre "estar ou não estar" filiado ao estatuto disciplinar, "Eis a questão!' uma disciplina, eis a questão!

Considerações Finais

Referências Bibliográficas

$\begin{array}{ll}\text { Anexos - Parte A } & 188\end{array}$

Anexo A 188

Anexo B $r$

Anexo C 196

Anexo D 199

Anexo E 201

$\begin{array}{ll}\text { Anexo F } & 203\end{array}$

$\begin{array}{lr}\text { Anexos - Parte B } & 204\end{array}$

Anexo G 204

Anexo H 205

Anexo I 206

$\begin{array}{ll}\text { Anexo J } & 207\end{array}$

Anexo K 208

Anexo L 209

$\begin{array}{ll}\text { Anexo M } & 210\end{array}$ 


\section{FOLHA DE APROVAÇÃO}

Priscila Oliveira Vieira

¿ "Español sin fronteras"? Ou entre as fronteiras

projetadas pelo imaginário e pelo real?

Dissertação apresentada ao Programa de Pós-Graduação em Língua Espanhola e Literaturas Espanhola e Hispano-americana do Departamento de Letras Modernas da Faculdade de Filosofia,Letras e Ciências Humanas da Universidade de São Paulo, para obtenção do título de Mestre em Língua Espanhola.

Área de concentração: Línguas Estrangeiras Modernas - Espanhol

Aprovado em:

\section{BANCA EXAMINADORA}

Profa. Dra. María Teresa Celada

(Orientadora)

Profa. Dra. Cláudia Regina Castellanos Pfeiffer (UNICAMP)

Profa. Dra. Neide Maia González (DLM/USP)

\section{SUPLENTES:}

Profa. Dra. Mónica Zoppi-Fontana (UNICAMP)

Profa. Dra. María Zulma M. Kulikowski (DLM/USP)

Profa. Dra. Mônica Ferreira Mairink O'Kuinghttons (DLM/USP) 
Aos meus pais que, com amor e paciência, sempre me ajudam a transpor as diferentes "fronteiras" da vida. 


\section{Agradecimentos}

Primeiramente, agradeço a Deus, pela vida, pela saúde, pelo caráter e pelas pessoas especiais que colocou em meu caminho.

A Maite Celada, pela confiança e dedicação "sem fronteiras", pela orientação cuidadosa, por todos os conhecimentos e saberes que comigo compartilhou, abrindo-me sentidos que, certamente, permitiram evoluir tanto no âmbito acadêmico, quanto no profissional e no pessoal.

A Neide Maia González, pelas contribuições valiosas de suas aulas durante minha formação em Letras e pela presteza e honra em conceder-me uma entrevista que, seguramente, será produtiva, também, para pesquisas futuras.

A Claudia Pfeiffer que, com sua leitura atenta e seu amplo conhecimento em Análise do Discurso, ajudou-me a aprofundar minhas análises e a repensar os sentidos de minha própria escrita.

A Josephine Sánchez Hernández, pelo carinho e prontidão com que sempre respondeu minhas dúvidas referentes à coleção Español sin fronteras, contribuindo, assim, para a precisão das informações que apresentamos sobre a mesma.

A Mirtha Daisy Bustos, por me "abrir as portas" para o universo do ensino da língua espanhola no contexto escolar com muita receptividade e compartilhar suas experiências e inquietudes em relação ao estatuto peculiar dessa língua nas escolas.

Às amigas: Amanda Valentin, a amiga de sempre e sempre amiga, imprescindível para compartilhar alguns sentidos cujos efeitos apenas ela é capaz de compreender; a Ariane Klebis, que com sua serenidade é sempre o meu alento e a Juliana Zunhiga, pelo carinho e admiração que sempre demonstrou.

A todos os meus alunos, inclusive e especialmente, aos que questionavam e/ou ainda questionam o ensino da língua espanhola e, assim, impulsionam minhas pesquisas e reflexões sobre o estatuto dessa língua, enquanto disciplina, nas escolas.

A minha família de convívio diário, ao Roberto (meu alicerce), a Gracinda (meu ponto de (des)equilíbrio) e, também, a Paula (que como típica geminiana consegue ser, ao mesmo tempo, meu oposto e meu complemento).

Aos familiares não tão próximos, mas que nunca deixam de acreditar, de torcer e de me apoiar: Maria, Maria de Lourdes, Gorete, Viviane e Vanessa. E, àqueles que estão a uma distância eterna, mas a uma presença constante: Antônio, Laura e Joaquim (em memória).

E, finalmente, ao Eduardo pela paciência, pelo carinho, pela companhia, pela bondade e pela calma que, a cada dia, faz com que o nosso amor seja, simultaneamente, a "estrutura" e o "acontecimento" de nossa união. 
A preocupação de si é uma espécie de ferrão que deve ser fincado aí, na carne dos homens, que deve ser cravado em sua existência e que é um princípio de movimento, um princípio de inquietação permanente ao longo da existência.

(Michel Foucault) 


\section{RESUMO}

VIEIRA, P. O. ¿"Español sin fronteras”? Ou entre as fronteiras projetadas pelo imaginário e pelo real? 204f. Dissertação (Mestrado) - Faculdade de Filosofia, Letras e Ciências Humanas, Universidade de São Paulo. São Paulo, 2012.

Neste trabalho, partimos da hipótese de que a língua espanhola (LE) aparece vinculada a um imaginário a partir do qual se materializam determinados enunciados, recorrentes em certas práticas discursivas do espaço escolar, que atribuem a essa língua um estatuto o qual caracterizamos como "não disciplinar". Assim, objetivamos analisar os sentidos que compõem esse imaginário no espaço de enunciação escolar por meio da análise de um elemento importante no processo de ensino-aprendizagem dentro desse espaço: o livro didático. Para tanto, selecionamos como objeto central de nosso estudo uma coleção didática de LE de presença expressiva no ensino fundamental: a coleção Español sin fronteras $(E S F)$, lançada em 1996 e reeditada em 2002 e em 2007, pela editora Scipione. Adotamos a vertente teórica da Análise do Discurso de linha francesa e, dessa perspectiva, colocamos a referida coleção em relações de sentido com suas condições de produção, num sentido amplo; portanto, essa análise abrange, também, o gesto de estabelecer relações com séries de sentidos constituídas no funcionamento da memória discursiva sobre o espanhol no Brasil e, de maneira específica, no que se refere a seu ensino-aprendizagem no espaço escolar.

Para desenvolver essa análise, organizamos esta dissertação em duas partes. $\mathrm{Na}$ primeira delas, analisamos como a LE é significada no arquivo jurídico, num recorte que atende, especificamente, ao ensino de línguas estrangeiras na escola e, estritamente, à língua espanhola. Além disso, identificamos séries de sentidos no funcionamento da memória discursiva sobre a LE e as interpretamos com base em textos introdutórios (paratextos) de certos instrumentos linguísticos, parte dos quais, acreditamos que também tenham tido uma presença expressiva no ensino dessa língua, entre os anos de 1930 a 1980, no espaço escolar. Na segunda parte, enfocamos nosso objeto central, a coleção $E S F$, em suas reedições - a partir de três de seus elementos paratextuais (título, capas e apresentações) - a fim de analisar como a LE é (re)significada.

Por meio do estudo realizado nessas duas partes poderemos, de um lado, observar que na constituição da memória discursiva sobre o ensino-aprendizagem de espanhol no Brasil predominaram, historicamente, os sentidos de facilidade e de informalidade; e, de outro, considerar que tais sentidos nos permitiriam compreender por que, no espaço de enunciação escolar, mesmo em tempos nos quais essa língua é apregoada como veicular, ela não se filia a um estatuto disciplinar - não conseguindo, portanto, ocupar o lugar de uma disciplina nesse espaço.

Palavras-chave: espanhol, instrumentos linguísticos, escola, disciplina, memória discursiva. 


\section{Abstract}

VIEIRA, P. O. "Spanish without borders"? Or between the borders projected by the imaginary and the real? 204p. Master's degree dissertation - Faculdade de Filosofia, Letras e Ciências Humanas, Universidade de São Paulo. São Paulo, 2012.

We start this work from the assumption that the Spanish language (SL) is connected to the imaginary in which some statements repeatedly materialize themselves in certain discursive practices in school, giving to this language the status that we carectarize as "non academic". According to this, we intend to analyze the senses that compose this imaginary in the school enunciation through an important element in the teaching-learning process: the textbook. To do so, we select as our study central object a SL collection of teaching materials which has expressive presence in primary school in Brazil: the Español sin fronteras $(E S F)$ "Spanish without borders" - collection, released in 1996 and republished in 2002 and 2007, by Scipione publishers. We adopt the French Discourse Analisis theory and, from this perspective, we put the referred collection in relation with its production conditions, in a broad sense; therefore, this analysis also covers the gesture of stablishing relations with senses series constituted in the functioning of discoursive memory about Spanish in Brazil, and in a specific way, referring to its teaching-learning process in school.

To develop this analysis, we organize this dissertation in two parts. In the first one, we analyse how the SL signifies in the legal files, in a selection that refers specifically to teaching foreign languages in school and restrictively to the Spanish language. Besides, we identify senses series in the functioning of discoursive memory about SL and we interpret them on basis of introductory texts (paratexts) in certain language instruments, some of what we believe that have also had expressive presence in teaching this language at school between the 1930s and 1980s. In the second part we focus on our central object, the ESF collection, in its republished versions - our starting point being its three paratexts (title, covers and introduction) - in order to analyse how the SL is (re)signified.

Through the study performed in the two first parts we will be able, on the one hand, to observe that in the constitution of the discoursive memory about the Spanish teachinglearning process in Brazil, the senses of informality and being easy have historically predominated; and on the other hand we consider that such senses would allow us to understand why, in the space of school enunciation, even in times in which this language is proclaimed as a vehicular one, it does not affiliate itself to a school subject status - and because of that it does not get to occupy the place of a school subject in this space.

Key words: Spanish, language instruments, school, school subject, discoursive memory. 


\section{INTRODUÇÃO}

Consideramos pertinente começar esta Introdução esclarecendo que, neste espaço, apresentaremos o histórico a partir do qual nos colocamos a questão que impulsiona nossa pesquisa. Esse será o primeiro item e o segmentaremos em duas partes para facilitar a leitura. A partir dele, estaremos em condições de delimitar nosso objeto, no item 2, e de determinar quais serão as partes desta dissertação, no item 3 .

\section{AS URGÊNCIAS DE NOSSA PRÁTICA}

“Por que estudar espanhol, professora? Nem no vestibular cai!". Essa é a pergunta que ecoa para nós desde o começo de nossa prática docente, com alunos do ensino fundamental II da rede particular de ensino da cidade de São Paulo, em $2007^{1}$, e que sempre nos causa certo desconforto. Desconforto este que, a partir das reflexões de Freud (1997), passamos a designar como um mal-estar.

$\mathrm{Na}$ tentativa de interpretar esse mal-estar à luz da teoria que nos servirá de base neste trabalho, a Análise do Discurso (doravante AD), começamos por ponderar que a língua espanhola (doravante referida, também, como LE), observada no espaço de enunciação ${ }^{2}$ escolar e ocupando, neste, o lugar de uma disciplina da grade curricular do ensino fundamental II, parecia - explorando a formulação de Eni Orlandi - "não se ajeitar nas

\footnotetext{
${ }^{1}$ Dentre as escolas nas quais lecionamos desde 2007, consideramos válido citar aquelas em que trabalhamos com alunos de ensino fundamental II em ordem cronológica: Colégio Tutto Amore, Colégio São José do Maranhão (2007), Escola Diocesana Virgem do Pilar (2007-2010), Colégio Passalacqua (que faz parte do sistema Vicentino composto por cinco colégios em São Paulo e em Jundiaí - em 2010) e Colégio Mary Ward (desde 2011).

${ }^{2}$ Mobilizaremos esse conceito em nossa pesquisa com base em Guimarães (2005, p. 18-19) e o apresentaremos em nosso Capítulo 1.
} 
evidências e no lugar já feito" que supõe o estatuto disciplinar ${ }^{3}$. Ou seja, na posição de docentes de uma prática que se inscreve no espaço de enunciação da escola, deparamo-nos, constantemente, com uma resistência que nos incomoda e nos desestimula e que se configurou como o disparador do projeto de pesquisa que desenvolvemos neste trabalho.

\subsection{Entendendo o nosso mal-estar: como ele irrompe na escola?}

Conforme o exposto, o que nos impulsiona é o interesse em entender a irrupção desse enunciado "Por que estudar espanhol, professora?" que, com a força do real, desestrutura nossas aulas e - pensando em nosso lugar de docentes - afeta as projeções imaginárias relacionadas com o que é ser professor, o que é uma disciplina e o que é ensiná-la na escola regular, o que é ensinar uma língua estrangeira que consideramos importante no contexto político-econômico brasileiro ${ }^{4}$ e assim por diante. A esse respeito, é preciso considerar que, nas práticas escolares, esse enunciado a partir do qual os alunos questionam a presença da LE na escola entra em relação com uma série de outros enunciados recorrentes, produzidos pelos docentes de LE e que se caracterizam por apresentar um tom de "queixa". Assim, observamos que em diversas interlocuções mantidas no espaço escolar, esses professores expressam o mal-estar, ao qual aqui nos referimos, tanto com relação à falta de interesse e, até mesmo, à resistência ao estudo dessa língua por parte de seus alunos, quanto com respeito a certas

\footnotetext{
${ }^{3}$ Esclarecemos que essa formulação de Orlandi é apresentada na "Nota ao leitor" que a autora escreve para a tradução que realizou da obra $O$ discurso: estrutura ou acontecimento, de Michel Pêcheux (em nossas referências bibliográficas, cf. Pêcheux, 2006). A observação realizada pela autora refere-se ao estatuto da AD, porém nos apropriamos dela porque seu modo de dizer é altamente produtivo para pensar nossa questão.

${ }^{4} \mathrm{~A}$ respeito das antecipações imaginárias às quais fazemos referência, consideramos relevante expor que, no começo de nossa graduação, em 2003, na Faculdade de Filosofia, Letras e Ciências Humanas da Universidade de São Paulo, um dos fatores que nos motivou a escolher o espanhol para nossa formação teve a ver, justamente, com as antecipações segundo as quais essa era uma língua que estava em expansão no mercado de trabalho nacional e que começava a ter um reconhecimento político-econômico muito forte, especialmente devido ao Mercosul e às relações comerciais entre o Brasil e os países hispano-americanos. Logo, ao verificarmos que, anos depois, esse reconhecimento ainda não havia chegado às salas de aula, passamos por muitas angústias e desconfortos.
} 
práticas instaladas nas instituições de ensino que, também, consideramos relevante destacar ${ }^{5}$.

Dentre essas práticas, enfocamos as reuniões pedagógicas e os conselhos de classe, nas quais destacamos dois enunciados recorrentes em relação à disciplina de espanhol, a saber: “Mas até ${ }^{6}$ em espanhol esse aluno não conseguiu nota!" e "Por que tantos alunos com notas baixas em espanhol, o que aconteceu, professor(a)?". No primeiro enunciado, os sentidos projetados pelo fragmento "até em espanhol" apontam a inclusão dessa língua, enquanto uma disciplina da escola, numa série de sentidos disfóricos. Interpretamos, ainda, que esta última é reforçada pelo fato de que o enunciado que a projeta é introduzido mediante o conector "mas" - o que funciona como indício de um embate na interlocução -, que coloca em dúvida a possibilidade de que o aluno não atinja o desempenho mínimo na disciplina de língua espanhola - dúvida esta que, de nosso ponto de vista, não observamos em relação a outras disciplinas. Já, no segundo enunciado, identificamos um tom de certa reprovação do professor quando um número excessivo de alunos não atinge o desempenho mínimo em espanhol.

Ante as reflexões que desenvolvemos, cabe observar que, em contrapartida, quando muitos alunos apresentam um desempenho baixo em outras disciplinas, como, por exemplo,

\footnotetext{
${ }^{5}$ A partir da observação de diversas práticas discursivas no espaço escolar, consideramos que podemos avaliar o que detectamos como uma falta de interesse pelo estudo dessa língua como um aspecto que não é pontual, isto é, específico de nossos alunos e de nossa experiência docente ou relacionado a um grupo determinado de alunos devido a aspectos tais como faixa etária ou características sócio-econômico-culturais. Entretanto, também ponderamos que não devemos caracterizar esse aspecto como um fato homogêneo, e sim como uma tendência, que acreditamos ser verificada, sobretudo, no Estado de São Paulo. Nesse sentido, vale a pena observar que na dissertação de mestrado de Silva (2009), da Universidade de Taubaté, que leva o título de Motivação para aprendizagem de Espanhol/Língua Estrangeira em turmas de Ensino Médio, a autora também parte da inquietação suscitada pelo "desinteresse" em relação ao estudo da língua espanhola que observa entre seus alunos. Em seu caso, à diferença do nosso, trata-se de alunos do Ensino Médio e de escolas da rede pública. Ante tal inquietação, que também - segundo afirma a docente - desestruturava suas aulas e a desmotivava, Silva objetiva trabalhá-la e analisá-la a partir de um enfoque diferente do nosso. Assim, desenvolveu técnicas de ensino a fim de que "o aluno fosse capaz de reconhecer a importância da língua espanhola em sua formação e de ter claras as razões pelas quais a disciplina foi incluída em sua grade curricular" (cf. SILVA, ibid., p.8) e, dessa forma, passasse a se interessar pelo estudo da mesma. Trazemos o caso dessa pesquisa para observar que os sentidos de nosso mal-estar ecoam no espaço de enunciação escolar - no caso, no contexto do ensino médio, de outra cidade do Estado de São Paulo e no âmbito da rede pública.

${ }^{6}$ A respeito do termo "até" empregado em enunciados recorrentes nas práticas institucionais as quais nos referimos é pertinente considerar as reflexões de Silva (1996, p. 153-154). Consoante a pesquisa dessa autora, poderíamos considerar a definição com a qual ela trabalha de que o "até" introduz o um "termo ínfimo de alguma série". Ao colocar essa interpretação em relações de sentido com o enunciado que enfocamos - "Mas até em espanhol o aluno não conseguiu nota!" - , entendemos que, no espaço de enunciação vinculado às práticas escolares, a língua espanhola é antecipada como uma disciplina de caráter ínfimo na "série" das que compõem a grade curricular.
} 
matemática, física, português, ciências, etc., percebemos que tal fato é interpretado como uma especificidade do grupo de alunos daquela sala ou associado à falta de estudo por parte dos mesmos. Nesse sentido, ponderamos que nos enunciados apresentados, com relação ao caso do espanhol como disciplina escolar, materializa-se uma antecipação imaginária projetada pelo corpo gestor das instituições - diretores e coordenadores - com relação a essa língua: a de que, em espanhol, diferentemente de outras disciplinas, todos os alunos ou a grande maioria deles, independentemente de suas dificuldades ou de seu estudo, conseguiriam atingir, pelo menos, o desempenho mínimo.

Ainda no âmbito das práticas escolares, abordaremos, também, um gesto, que entra em relação de sentidos com os enunciados que apresentamos e analisamos no parágrafo anterior. Referimo-nos a uma ação que observamos com regularidade por parte do corpo gestor das instituições, de considerar que "o desempenho insuficiente do aluno na disciplina de espanhol não deve ter um peso para contribuir a sua retenção.”. Trata-se de uma tendência observada, em relação aos diretores e coordenadores, a "sugerir" que o aluno seja aprovado nessa disciplina pelo conselho escolar (composto por todos os professores que lecionam para aquele aluno e pelos coordenadores e/ou diretores), quando o mesmo não atinge a média anual em um número maior de disciplinas do que o aceito pela instituição; assim, em vez de ser retido diretamente, é dada a ele a possibilidade de participar do processo de recuperação ${ }^{7}$.

A esse respeito e considerando as outras línguas da escola, cabe observar que, em nenhum caso, esses gestos que relacionamos à LE são verificados em relação à língua portuguesa. Já para abordar, especificamente, a língua estrangeira, precisamos esclarecer que,

\footnotetext{
${ }^{7}$ Consideramos relevante explicar em detalhe o funcionamento ao qual nos referimos. Muitas instituições de ensino determinam, em seus regimentos internos, um limite de disciplinas em que o aluno pode ficar abaixo da média prevista no final do ano letivo. Pensemos no caso em que esse número seja de quatro disciplinas e que a média anual mínima para aprovação seja 6,0; se um determinado aluno não atingir essa média em cinco disciplinas - por exemplo, português, ciências, história, geografia e espanhol - ele estaria retido. É justamente nesses casos que a equipe de coordenação e/ou gestão "sugere" ao conselho a aprovação do aluno na disciplina de espanhol, de modo que ele não seja diretamente retido e possa tentar recuperar a nota nas outras quatro disciplinas. Sendo uma "sugestão" proposta por uma instância hierárquica superior, a tendência é que os demais professores votem a favor.
} 
de forma geral e por funcionamento de um pré-construído, é a língua inglesa a que ocupa o estatuto de estrangeira na escola (cf. SOUSA, 2007); e, quando ela aparece junto com a LE no leque de disciplinas nas quais um aluno teve um desempenho baixo, a tendência que observamos acima se mantém, ou seja, "sugere-se" que a aprovação por conselho seja na disciplina de LE. Isso acontece a despeito do fato de que tanto o inglês quanto a LE são línguas estrangeiras e, portanto, disciplinas que integram a parte diversificada do currículo, conforme dispõe a LDB de 1996.

Ante tais reflexões, pareceu-nos pertinente estabelecer uma relação com a pesquisa desenvolvida por Carvalho (2010). O estudo dessa autora partiu da hipótese central de que o sujeito - no seu caso, o aluno da educação básica da rede pública de ensino - é interpelado por diferentes discursos (midiáticos, publicitários, político-econômico, cultura) e passa por um processo de identificação com relação ao "nativo" da língua inglesa e que nos referidos discursos aparece vinculado ao imaginário de sucesso profissional e econômico. Assim interpelado, Carvalho (ibidem.) identifica que esse sujeito expressa vontade e interesse de aprender essa língua. Vinculando o estudo dessa pesquisadora ao exposto em relação às condições da LE em determinadas práticas escolares, formulamos duas considerações. A primeira é a de que o sujeito - em nosso caso, o aluno da educação básica da rede particular de ensino e, também, da rede pública, se pensarmos na pesquisa que citamos de Silva (2009) não demonstra essa mesma identificação e interesse pelo estudo da LE. E, a segunda é que, de nosso ponto de vista, no âmbito escolar, as discursividades referentes à língua inglesa, detectadas por Carvalho (ibidem), não interpelam apenas o aluno, mas também a equipe gestora e coordenadora. Assim, com base no que apresentamos em relação ao fato de que embora a LDB de 1996 determine o ensino de uma língua estrangeira moderna a partir da quinta série sem especificar qual, entendemos que o gesto dos gestores e coordenadores de “sugerir" a aprovação em espanhol - e não em inglês -, nos casos em que o aluno não 
apresentou um desempenho mínimo, dá corpo à identificação imaginária com o inglês que justamente mantém essa língua enquanto "a língua estrangeira” da escola.

Essa consideração reforça nossa hipótese de que a língua espanhola parece não estar filiada, nas escolas, aos mesmos sentidos das demais áreas de estudo, sentidos estes que conferem a essas áreas o estatuto de disciplina. As reflexões que formulamos ao longo deste subitem nos permitiram esboçar, a partir de enunciados e gestos recorrentes nas práticas escolares, os principais indícios pelos quais o mal-estar, que apresentamos como impulsionador deste estudo, irrompe no espaço da escola. Passaremos, agora, a realizar uma abordagem teórica desse mal-estar que nos permita elaborar uma hipótese a respeito do mesmo.

\section{2. À luz da teoria, nosso mal-estar nos sinaliza uma hipótese}

Começamos por apresentar uma formulação de Orlandi que nos ajudará neste ponto:

Certamente haverá muitos sentidos a dar à noção de política linguística. E esses sentidos vão desde a tematização mais formal do planejamento de uma política linguística explícita assumida claramente como organizacional, até a observação de processos institucionais, menos evidentes, inscritos de forma implícita nos usos diferenciados (e diferenciadores) da linguagem. (ORLANDI, 1988a, p. 7, grifos nossos)

Sem deixar de levar em conta a linha de sentidos presente na primeira parte dessa definição - segundo a qual é preciso considerar "o planejamento de uma política linguística explicita assumida claramente como organizacional" -, acreditamos que a série de enunciados e gestos abordados no item anterior - que funcionam como indícios de que a língua espanhola "não se ajeita nas evidências e no lugar já feito" (cf. ORLANDI, 2006, p. 7) de uma disciplina entra em clara relação com o que a autora entende como uma política que deve ser interpretada mediante a observação de "processos institucionais" que estão inscritos nos usos diferenciados (e diferenciadores) da linguagem e que, em nosso caso específico, diríamos que 
estão inscritos nas práticas mediante as quais é administrado ou gerenciado o funcionamento das disciplinas (e das línguas) - práticas que acabam tendo um efeito sobre as próprias disciplinas e sobre o modo como a instituição as significa.

Sousa (2007, p. 13) - como já adiantamos - destaca que, embora a LDB de 1996 não especifique qual língua estrangeira moderna deve ser ensinada nas escolas e determine que sua escolha deve ficar a cargo da "comunidade escolar"», na prática, a língua inglesa monopoliza, de maneira implícita, este lugar na grade curricular da maioria das instituições de ensino regulares. A pesquisadora ${ }^{9}$ entende que isto se deve ao funcionamento de um préconstruído segundo o qual o inglês é considerado a língua "para comunicação internacional" por ser filiado a uma série de sentidos: língua de negócios, língua obrigatória, língua de acesso ao mercado de trabalho, língua franca, língua universal, etc. ${ }^{10}-$ sentidos estes que lhe atribuem o estatuto de língua veicular (cf. GOBARD; DELEUZE e GUATARI apud CELADA, 2002, p. $27^{11}$ ). Esse aspecto, de nossa perspectiva, permite-nos, em primeiro lugar, observar que seu estatuto, como disciplina, não é problematizado nem por parte das autoridades escolares, nem por parte do corpo docente nem pelos alunos e pais (todos os que comporiam a comunidade escolar); e, em segundo lugar, interpretar que a força desse préconstruído relacionado à língua inglesa é mais um dos fatores que contribuem para que a língua espanhola ocupe, na escola, um lugar que caracterizamos como “não-disciplinar”, visto que o lugar “disciplinar” concedido à língua estrangeira já está preenchido.

\footnotetext{
8 Antecipamos que a LDB de 1996 será analisada no Capítulo 1 desta dissertação e que abordaremos a indeterminação projetada pelo termo "comunidade escolar".

${ }^{9}$ Ibidem.

${ }^{10}$ Ibidem.

${ }^{11}$ As obras que Celada (ibidem) mobiliza dos referidos autores são, respectivamente: GOBARD, H. (1972). De la véhicularité de la langue anglaise (de l'anglais langue étrangère à l'anglais naturalisé). In: Les Langues Modernes, jan., p. 59-66. E DELEUZE. G; GUATTARI, F. (1977). "O que é uma literatura menor?" In: Kafka. Por uma literatura menor. (Trad. por Júlio Castañon Guimarães.) Rio de Janeiro: Imago. (Original em francês: Kafka. Pour une littérature mineure. Paris: Editions de Minuit, 1975.).
} 


\section{A DELIMITAÇÃo DE NOSSO OBJETO}

A interpretação de várias das razões que desatam o que designamos como mal-estar, considerando aspectos das condições de produção do espanhol em contexto escolar, sinalizounos a hipótese que, neste ponto, retomamos: a de que a língua espanhola, na escola, diferentemente da inglesa e de outras áreas de estudo, não estaria vinculada a sentidos que lhe atribuam um lugar disciplinar ou que garantam seu estatuto como disciplina. Por isso, essa língua é, frequentemente, submetida a questionamentos e, até mesmo, à manifestação de diversas formas de resistência por parte dos sujeitos que habitam esse espaço, fundamentalmente, alunos, gestores e coordenadores - situações estas que justamente alimentam o já referido mal-estar em outro sujeito desse mesmo espaço: o professor ${ }^{12}$.

Diante da formulação dessa hipótese e da compreensão de processos que a mesma nos possibilita, decidimos iniciar a presente pesquisa com o objetivo de compreender a quais sentidos, de forma específica, a língua espanhola está filiada no espaço de enunciação escolar, de modo que ela, para usar uma forma expressiva, não "tenha cacife" para funcionar como uma disciplina nesse espaço. Esse objetivo se encaixa num horizonte maior que implica contemplar o processo de constituição de sentidos (e os movimentos de apagamento, de deslocamento, de cristalização que essa constituição abrange) no funcionamento da memória discursiva sobre o espanhol no Brasil.

Neste trabalho, olharemos para esse horizonte mais geral, porém, no que se refere a trabalhar com os sentidos aos que se filia o espanhol no espaço escolar, consideramos que uma análise de livros didáticos poderia ser produtiva, uma vez que segundo Souza (1999a, p. 27), dentro da escola:

\footnotetext{
${ }^{12} \mathrm{Na}$ verdade, nestas alturas, já seria necessário reconhecer que esse mal-estar também estaria nos próprios alunos que não conseguem dar imaginariamente a essa língua um lugar pelo qual sintam que vale a pena o trabalho de se submeter a seu estudo.
} 
O caráter de autoridade do livro didático encontra sua legitimidade na crença de que ele é depositário de um saber a ser decifrado, pois supõe-se que o livro didático contenha uma verdade sacramentada a ser transmitida e compartilhada. Verdade já dada que o professor, legitimado institucionalmente autorizado a manejar o livro didático, deve apenas produzir, cabendo ao aluno assimilá-la. (grifos nossos)

A autora acrescenta que esses livros têm sido, tradicionalmente, o principal mediador do ensino promovido pela instituição-escola. ${ }^{13}$ Levando em conta esse caráter do livro didático, definimos que este será nosso posto de observação central mediante a análise dos elementos paratextuais - pensados, em parte, como "discursos sobre" conforme Mariani (1998, p. 60 apud RODRIGUES, 2010, p. 199) -, pois acreditamos que poderemos analisar dizeres sobre a LE e identificar os sentidos com os quais ela é significada em diferentes condições de produção.

Assim sendo, escolhemos como elemento estruturador de nosso corpus as três edições de uma coleção de livros didáticos de espanhol - Español sin fronteras - publicada pela editora Scipione e escrita por autoras com formação superior em universidade brasileira Josephine Sánchez Hernández e María de Los Ángeles Jiménez García. É válido acrescentar que priorizamos a escolha deste material com base em três critérios principais: o primeiro seria o fato de ter sido publicado por uma editora nacional; o segundo o de ter sido escrito por autoras com formação superior e com experiência docente no Brasil; e o terceiro critério foi o fato de esta coleção ter sido, durante muitos anos, uma das mais vendidas no Brasil, tanto para escolas de ensino regular, quanto para centros de idiomas, sendo adotada não apenas para o ensino fundamental II, mas também para o ensino médio ${ }^{14}$, além de ter passado por reedições e ser publicada até os dias de hoje. Este último aspecto foi relevante para a escolha da coleção Español sin fronteras, pois acreditamos que o fato de que a mesma tenha tido mais de uma edição nos permitirá observar - na série de elementos paratextuais que abordaremos - como a

\footnotetext{
${ }^{13}$ Cf. SOUZA, ibidem, p. 94

${ }^{14} \mathrm{~A}$ informação com relação à vendagem desse livro foi obtida através de uma consulta enviada à equipe editorial de livros didáticos da editora Scipione, com a então editora responsável Lidiane Olo. (Informação pessoal recebida de lidiane.olo@ scipione.com.br em 20 mar. 2008.)
} 
língua espanhola foi sendo (re)significada ao longo do processo de reformulação dessa coleção, lançada em 1996 e reeditada em 2002 e $2007^{15}$.

Ao fazer esse primeiro recorte, percebemos que realizaríamos em nossa pesquisa um processo de abertura de arquivo, interpretando o termo arquivo à luz de Pêcheux (2010, p. 51) que o define "no sentido amplo de "campo de documentos pertinentes e disponíveis sobre uma questão"”. Em nosso caso, a questão, conforme já apresentamos, seria detectar os sentidos atribuídos à LE em domínios discursivos relativos ao espaço escolar e tentar compreender o processo pelo qual esta se filia em tal espaço a um estatuto que caracterizamos como "nãodisciplinar"; assim, nosso "campo de documentos" seria, fundamentalmente, uma coleção didática de LE escolhida com base nas justificativas que já apresentamos. No entanto, por trabalhar essa coleção a partir da vertente teórica da AD, estávamos cientes de que teríamos que analisá-la como um objeto discursivo, o que - a partir das considerações de Orlandi (2007a, p. 30) - implica que deveríamos contemplar dois aspectos fundamentais:

a) o primeiro é que todo objeto discursivo é composto por dizeres que não são apenas mensagens a serem decodificadas, mas efeitos de sentidos produzidos em condições determinadas e que podem ser percebidos a partir de sua relação com a exterioridade, isto é, com suas condições de produção ${ }^{16}$;

b) o segundo é que esses sentidos têm a ver com o que é dito ali, mas também em outros lugares, assim como com o que não é dito e com o que poderia ser dito. Ou seja, com todos os dizeres e sentidos que compõem a memória discursiva ${ }^{17}$.

Portanto, considerando que o objeto fundamental de nosso arquivo, concebido enquanto discursivo, deveria entrar em relação com as condições de produção e com os sentidos da memória discursiva sobre o espanhol no Brasil - nesse horizonte mais amplo que

\footnotetext{
${ }^{15}$ Esclarecemos que no final de 2011 foi publicada uma $4^{a}$ edição da coleção $E S F$, porém como já estávamos na fase final de nossa pesquisa, não a analisamos nesta dissertação.

${ }^{16}$ ORLANDI, Ibidem.

${ }^{17}$ ORLANDI, Ibidem.
} 
sinalizamos ao iniciar este item - percebemos a necessidade de enfocar outros livros e “materiais didáticos" abordando-os como instrumentos linguísticos (cf. AUROUX, 1992 e DINIZ, 2010). Por isso, analisaremos aqueles livros (e materiais didáticos) aos que conseguimos ter acesso, produzidos entre as décadas de 20 e de 80 e que inferimos que tenham tido relevância para o ensino-aprendizagem dessa língua na escola brasileira. Além disso, colocaremos esse arquivo (os dos instrumentos linguísticos) em relação com outro: o dos documentos jurídicos relativos ao ensino das línguas estrangeiras na escola. Com a análise destes objetivamos ter acesso às condições de produção que viabilizaram a inserção da língua espanhola no espaço escolar bem como aos sentidos projetados sobre essa língua e os efeitos produzidos para que a mesma entrasse nesse espaço. Já com a análise dos instrumentos linguísticos de língua espanhola publicados anteriormente à coleção Español sin fronteras, objetivamos ter acesso aos sentidos que começaram a circular no espaço escolar brasileiro por meio da prática de ensino-aprendizagem formal dessa língua - abordando, assim, o funcionamento da memória discursiva sobre a LE no Brasil. Mediante o trabalho de análise de ambos arquivos e das relações que possamos estabelecer estaremos interpretando as condições de produção da coleção, que será o objeto central de nosso corpus.

Este trabalho consistirá, portanto, a partir dessa perspectiva, em produzir um gesto de interpretação que relacione esses dois arquivos: o dos documentos jurídicos e os dos instrumentos linguísticos - explorando, neste caso, elementos paratextuais tanto dos instrumentos produzidos entre os anos 20 e os anos 80 quanto do que definimos como nosso objeto central: a coleção didática Español sin fronteras, lançada nos anos 90 e publicada até os dias atuais. E, ainda, a pergunta "Por que estudar espanhol, professora?", pronunciada no real de nossa prática docente, estará em nosso horizonte de forma que os resultados desta pesquisa nos permitam compreender melhor os sentidos de nossa questão disparadora: o malestar que vivenciamos em nossa prática cotidiana. 


\section{SOBRE AS PARTES DESTA DISSERTAÇÃO}

A partir da delimitação de nosso objeto - a coleção didática de LE, Español sin fronteras - e da configuração de nosso corpus (no qual mobilizaremos, fundamentalmente, dois arquivos), dividimos nossa dissertação em duas partes. Antes de passar a descrevê-las, é preciso dizer que a estrutura da mesma foi pensada discursivamente, a partir de nosso lugar teórico, e que a mobilização dos conceitos será realizada de acordo com as necessidades que nos provoca nossa análise. Na primeira, cujo título é "Abrindo arquivos sobre ensino de LE no Brasil”, mobilizaremos dois arquivos a fim de analisar as condições de produção relacionadas ao ensino da LE nas escolas e o funcionamento da memória discursiva sobre essa língua nesse espaço de enunciação. Por sua vez, essa primeira parte nos permitirá analisar as condições de produção da coleção que será objeto central na segunda parte, cujo título é "Com foco em 'Español sin fronteras"'. Nesta, que continua o gesto de abertura do arquivo dos instrumentos linguísticos analisados na primeira parte, interpretaremos os sentidos projetados sobre essa língua e suas ressignificações, a partir da abordagem de elementos paratextuais (título, capas e apresentação) das três reedições da já referida coleção didática, Español sin fronteras, presente no espaço escolar contemporâneo.

A primeira parte está composta por dois capítulos. No Capítulo 1, analisaremos - com base, fundamentalmente, numa pesquisa já desenvolvida na área da $\mathrm{AD}$ - documentos jurídicos relativos ao ensino de línguas estrangeiras, especialmente da LE, nas escolas brasileiras. No trabalho de colocar em relação de sentidos o texto jurídico com outros discursos, mobilizaremos estudos de historiadores, de estudiosos do campo da educação e, também, uma entrevista que realizamos, em 2011, à profa. Dra. González ${ }^{18}$. Neste caso, vale

\footnotetext{
${ }^{18}$ Esclarecemos que nossa entrevistada, Neide Maia González, é professora doutora aposentada da Faculdade de Filosofia Letras e Ciências Humanas da Universidade de São Paulo, onde foi docente do Curso de
} 
esclarecer que a renomada docente e pesquisadora da área de Língua Espanhola viveu parte da época na qual essa língua fazia parte da grade curricular e, portanto, vivenciou a relação com a mesma no real do espaço escolar. A entrevista inclui relatos relevantes para a análise e que são feitos à luz da experiência de uma docente e pesquisadora - fato que os torna especialmente significativos. No Capítulo 2, abordaremos as introduções e/ou os textos introdutórios de instrumentos linguísticos relativos à LE, produzidos desde a década de 20 até a década de 80, com o intuito principal de observar como a língua espanhola é, nesse discurso, significada.

Já, a segunda parte está composta por outros dois capítulos: o terceiro e o quarto. No Capítulo 3, objetivamos analisar como a dupla determinação que identificamos na materialidade linguística do enunciado Español sin fronteras, título da coleção didática que focalizaremos, será (re)significada em cada uma de suas três edições. Para tanto, colocaremos esse título em relação de sentidos com as capas e com fragmentos das apresentações das três edições de $E S F^{19}$. E, no Capítulo 4, o último desta dissertação, focalizaremos a apresentação da terceira edição. Este capítulo, pela retomada que fará de conceitos teóricos e de aspectos relativos ao funcionamento da memória discursiva sobre o espanhol na escola brasileira, terá um caráter conclusivo não apenas com relação à análise que faremos da ESF mas também às

\footnotetext{
Letras/Habilitação Espanhol, no qual formou professores e pesquisadores de língua espanhola desde 1972 até 2008 (com uma interrupção de quatro anos no meio). Hoje continua atuando em nível de pós-graduação, sendo responsável pela formação de grande quantidade de mestres e doutores. Em relação a sua trajetória profissional destacam-se, também, as seguintes atuações: foi tradutora pública e de obras literárias; realizou e realiza pesquisas no campo dos estudos sobre o funcionamento da língua espanhola (no contraste com o português brasileiro), da aquisição de língua espanhola por brasileiros; de teoria e da prática da tradução e de políticas linguísticas, sobretudo com relação ao ensino da língua espanhola no Brasil; é coautora das Orientações Curriculares para o Ensino Médio (Linguagens, Códigos e suas Tecnologias: Conhecimentos de Espanhol, MECSEB, 2006); tem se dedicado à análise crítica de materiais didáticos para o ensino de espanhol (Ensino Fundamental e Médio); e foi representante da área de línguas estrangeiras na Comissão Técnica do PNLD 2012, Ensino Fundamental. (Parte destas informações foi obtida a partir da Currículo Lattes da referida professora, Disponível em < http://buscatextual.cnpq.br/buscatextual/visualizacv.do?metodo=apresentar\&id=K4796121H0 $>$ Acesso em 26 abr.2012)

Cabe esclarecer que o total da entrevista, pela qual aproveitamos para agradecer especialmente à Profa. González, é muito rico e produtivo para conhecer aspectos do funcionamento da memória discursiva sobre o espanhol no Brasil. De fato, ele não será explorado integralmente nesta dissertação e ficará como um texto passível de ser retomado em novos estudos.

${ }^{19}$ Esclarecemos que, doravante, também utilizaremos essa sigla, composta pelas letras iniciais dos sintagmas do título dessa coleção para nos referirmos a mesma.
} 
considerações que encerrarão a primeira parte, permitindo, inclusive, que retomemos a questão colocada nesta Introdução.

Concluiremos nosso trabalho com as Considerações Finais. $\mathrm{Na}$ sequência apresentaremos as Referências Bibliográficas e, por fim, a seção de Anexos, organizada da seguinte maneira: a parte A compreenderá as normas utilizadas para a transcrição da entrevista e a própria entrevista realizada com a profa. Dra. González e as introduções e textos introdutórios dos instrumentos linguísticos publicados até a década de 80 que serão objeto de análise no Capítulo 2. Já a parte B estará composta pelas capas e pelas apresentações das três edições da coleção Español sin fronteras, cujas análises serão abordadas na segunda parte desta dissertação. 


\section{PARTe I}

\section{ABRINDO ARQUIVOS SOBRE O ENSINO DE LE NO BRASIL}

Esta primeira parte destina-se à análise de textos que nos permitirão abordar aspectos das condições de produção da coleção didática Español sin fronteras $(E S F)$, objeto central de nosso corpus. Dessa forma, também poderemos interpretar o funcionamento dos sentidos na memória discursiva sobre o espanhol no Brasil - nesse horizonte mais amplo que nos propomos pesquisar nesta dissertação - e, especificamente, no espaço escolar.

Como já dissemos na Introdução, mobilizaremos dois arquivos e, por isso, trabalharemos com dois capítulos. No primeiro deles, analisaremos documentos jurídicos sobre o ensino de línguas estrangeiras, e, especificamente, da língua espanhola na escola brasileira. Já no segundo, passamos a abrir o arquivo dos instrumentos linguísticos sobre LE, produzidos no Brasil, e analisamos as introduções de alguns deles, todos os quais inferimos que tiveram uma certa relevância no contexto educacional brasileiro. 


\section{Capítulo 1}

\section{O ARQUIVO DOS DOCUMENTOS JURÍDICOS E A LE NA EDUCAÇÃO BRASILEIRA}

Consoante ao apresentado na Introdução desta dissertação, este capítulo tem como objetivo analisar as condições de produção envolvidas no processo no qual as línguas estrangeiras e, especialmente, a língua espanhola passaram a fazer parte do currículo oficial das escolas brasileiras. Além disso, serão analisados os sentidos projetados sobre essa língua em sua relação com o espaço de enunciação escolar.

Para tanto, abordaremos a análise de fragmentos dos documentos jurídicos, ou seja, os textos com os quais se constroem e se impõem as leis (cf. RODRIGUES, 2010, p. 194). Em meio ao conjunto de documentos do arquivo jurídico, é válido enfatizar que, segundo nosso objetivo, selecionamos aqueles relacionados ao ensino das línguas estrangeiras no Brasil e, especialmente, ao ensino da língua espanhola. E, com base na pesquisa realizada por Rodrigues (2010), seguiremos dois recortes para guiar a análise que nos revelará diferentes movimentos relacionados aos processos de inclusão/exclusão das línguas estrangeiras na escola. $^{20}$

No primeiro deles, item 1., entram os decretos que foram produzidos a partir de diferentes reformas ocorridas entre o período de 1757 a $1942^{21}$, a fim de normatizar o ensino de línguas estrangeiras em contexto formal e de determiná-las no arquivo jurídico, conforme a

\footnotetext{
${ }^{20}$ Assim, pelo gesto de leitura que já implicam esses recortes, mostramos que nosso trabalho toma como base a concepção de arquivo da AD. Segundo Guilhamou e Maldidier (2010, p.162), o mesmo nunca é dado a priori e a identificação puramente institucional (a partir de datas, nomes ou chancelas) dos documentos que o compõe não é suficiente. Assim sendo, a organização de um arquivo a partir da teoria discursiva dá-se mediante gestos de leitura que acabam revelando o que esses autores (ibidem.) chamam de história social dos textos.

${ }^{21}$ Salientamos que, embora o período que determinamos para nosso estudo seja extenso, recortaremos apenas os decretos que apresentaram alguma normativa relacionada ao ensino de línguas estrangeiras e não todos os documentos jurídicos referentes à educação no Brasil.
} 
análise desenvolvida por Rodrigues ${ }^{22}$. É válido esclarecer que, segundo a autora, os decretos se configuram como normas jurídicas que não são aprovadas pelo Congresso Nacional (Poder Legislativo, composto por senadores e deputados), isto é, são diretamente impostas pelo Presidente da República (Poder Executivo) em exercício. A análise desses decretos permitirnos-á identificar um movimento que exploraremos durante nossas análises e que compreendemos a partir de processos políticos de suas inclusões e exclusões no currículo escolar oficial.

Já no segundo recorte, item 2., estão incluídas as LDBs que, de acordo com Rodrigues $^{23}$, diferentemente dos decretos, são textos que tramitaram e foram aprovados no Congresso Nacional, recebendo a sanção presidencial apenas após esse processo de tramitação em Congresso. É relevante considerarmos também que a primeira LDB, promulgada em 1961, diferencia-se dos decretos que compõem nosso primeiro recorte não apenas por ter sido um texto jurídico que tramitou e foi aprovado em Congresso Nacional, mas por configurar-se, conforme Silva (2010, p. 170) e conforme Rodrigues ${ }^{24}$, como um acontecimento discursivo. Para Silva ${ }^{25}$, essa LDB representa um acontecimento discursivo por ter sido marcante na relação Estado/Sociedade/Nação uma vez que representou a legitimação/materialização da educação e da língua nacional pelo Estado. Segundo as análises desenvolvidas das Constituições Federais de 1891 até 1946, o pesquisador pôde verificar que havia, na materialidade discursiva das mesmas, um dualismo entre a centralização e a descentralização da educação, ou seja, deixava-se a educação a cargo da União e dos Estados ao mesmo tempo ${ }^{26}$. Já, a partir da análise da LDB de 1961, o autor conclui que esse dualismo é desconstruído uma vez que:

É o momento que o Estado assume o papel de

\footnotetext{
${ }^{22}$ Ibidem.

${ }^{23}$ Ibidem., p. 17

${ }^{24}$ Ibidem., p. 298

${ }^{25}$ Ibidem

${ }^{26}$ Ibidem. p. 149.
} 
articulador/organizador/definidor não de um nível/ramo/tipo de instrução ou ensino, mas da educação. Assim, pela primeira vez, o Estado brasileiro não só legitima sua competência para traçar a educação nacional, mas efetiva esta competência. ${ }^{27}$

Por outro lado, para Rodrigues (2010, p. 298), a LDB de 1961 também pode ser entendida como um acontecimento discursivo, mas por ter reorganizado a memória sobre o ensino de línguas no espaço escolar brasileiro. Essa reorganização, que se iniciou com a LDB de 1961 e que teve continuidade com as LDBs posteriores de 1971 e 1996, ocorreu, segundo a autora $^{28}$, a partir de dois processos que exploraremos ainda neste capítulo: um de apagamento e outro de indeterminação ${ }^{29}$, sendo ambos relacionados às línguas estrangeiras nos documentos jurídicos.

É pertinente mencionar que, ademais da pesquisa sobre os documentos jurídicos relacionados ao ensino de línguas no Brasil realizado por Rodrigues ${ }^{30}$, pautar-nos-emos, também, em estudos desenvolvidos por outros autores, como Picanço (2003) - na área da educação -, Eckert-Hoff (2010) - sobretudo no que se refere à língua alemã como de imigração - e Souza (2005) - que trabalha na área do discurso, também em questões muito próximas as destas dissertação. Além disso, na análise de nosso corpus, mobilizaremos fragmentos da entrevista que, como já dissemos em nossa Introdução, foi realizada a González em 2011.

\section{REFORMAS E DECRETOS.}

Neste primeiro item enfocaremos as reformas - e os decretos que as materializaram

\footnotetext{
${ }^{27}$ Ibidem., p. 150.

${ }^{28}$ Ibidem.

${ }^{29}$ Tais movimentos serão explicitados e analisados no item 3 deste capítulo.

${ }^{30}$ Ibid.
} 
juridicamente - cujos objetivos eram determinar as línguas estrangeiras ${ }^{31}$ no espaço de enunciação da escola. De acordo com Rodrigues (2010, p. 39-45), é no período colonial, mais especificamente no ano 1757, que se verifica uma preocupação especial com relação ao ensino de línguas na educação pública brasileira, oficializada por meio de uma normativa chamada de Diretório dos Índios, datada de 3 de maio do mesmo ano e escrita por Sebastião José de Carvalho e Melo que, futuramente, receberia o título de Marquês de Pombal. Ainda segundo a estudiosa, esse Diretório teve grande relevância porque, após duzentos e dez anos de uma educação organizada pelos jesuítas, obrigou o então Estado Português a reorganizar a educação em seus domínios, tanto na metrópole, como em suas colônias na América ${ }^{32}$ e, também e principalmente, porque impôs a língua portuguesa a estas.

Consideramos válido enfatizar esse aspecto do referido Diretório, ou seja, o de institucionalizar e oficializar de modo impositivo por meio de um ato político-jurídico, a língua que devia ser falada, ensinada e escrita (a língua portuguesa) nos moldes da gramática vigente na Corte (cf. MARIANI, 2004, p. 33). Nas análises desenvolvidas por Mariani, a autora destaca ainda que esse Diretório buscava "colocar em silêncio" a língua geral ${ }^{33}$

\footnotetext{
${ }^{31}$ Com relação ao termo "línguas estrangeiras", consideramos válido desestabilizar as evidências discursivas que o mesmo pode produzir. Para tanto, recorremos aos estudos de Mariani $(2004$, p. 28) sobre o período colonial no qual a autora observa que havia um encontro da língua do colonizador (que veio a tornar-se a língua oficial do Brasil) com outras línguas, a saber: as europeias, africanas e indígenas. Ante esse contexto, a autora (ibid. p. 55) pondera que cada uma dessas línguas será, conforme as circunstâncias, língua primeira (ou materna) ou língua segunda (ou estrangeira). Ou seja, ao mesmo tempo em que se poderia considerar a língua brasílica (ou língua geral) como a materna para bandeirantes, mamelucos e índios, dever-se-ia considerá-la estrangeira para os padres jesuítas e alguns administradores locais. Inversamente, a língua portuguesa também poderia ser materna ou estrangeira de acordo com a circunstância. Nesse sentido, estamos cientes desse contexto e também de que mesmo após a força coerciva do Diretório dos Índios que institucionalizou a língua portuguesa como língua oficial do Brasil colônia e que segue sendo a língua oficial do Brasil atual, as outras línguas continuaram e continuam a circular nesse espaço de enunciação. Portanto, quando utilizamos o termo línguas estrangeiras estamos considerando as outras línguas que são ensinadas nas escolas, mas que não são a língua imposta como oficial e nacional ao Brasil, isto é, a portuguesa.

${ }^{32}$ Ibidem., p. 43.

${ }^{33}$ Mariani (ibidem., p. 22) considera, com base na obra de Aryon Rodrigues - As línguas brasileiras. São Paulo: Loyola, 1986 -, como língua geral o chamado tupi Jesuítico, ou seja, aquele resultante do uso e transformação que os missionários fizeram da língua tupinambá usada na costa, para fins catequéticos. Nesse sentido, essa definição nos leva a entender, ainda, com base em Orlandi (1996), que se trata de uma língua imaginária fixada em sistematizações gramaticais apriorísticas. O texto de Orlandi que lhe permite essa reflexão é: ORLANDI, Eni P. La langue brésiliénne (des effects de la colonisation sur la langue). In: Du dire et du Discours, hommage a Denise Maldidier. NORMAND, Claudine e SITRI, Frederic (Org.). Número Especial de LINX. Nanterre: Université Paris X, Centre de Recherches Lingusitiques, 1996.
} 
(segundo a própria autora, o "português-brasileiro") e seus falantes, ou seja, os índios. O mesmo se verifica na análise que Guimarães (2000, p. 169-179) desenvolve sobre a língua nacional nas Constituições brasileiras. A partir de sua análise, o autor conclui que as línguas indígenas eram reconhecidas pela Constituição, porém esse documento oficial não as considerava como línguas do/para o Estado. Assim sendo, o pesquisador pondera que estar no Brasil, como (índios) falantes dessas línguas, mesmo que desde o nascimento, não significava a inserção destes no Estado - ponderação que lhe permite concluir (GUIMARÃES ${ }^{34}$ ) que, para ser considerado brasileiro, era necessário falar a língua portuguesa.

Nesse sentido, podemos entender como essa política, iniciada a partir do Diretório e continuada com a Constituição de 1988, deu início à organização de uma divisão e disputa de línguas no espaço de enunciação brasileiro, em que, com base em Guimarães ${ }^{35}$, a língua do Estado deveria ser uma língua de civilização ${ }^{36}$, no caso a portuguesa, e a multiplicidade, isto é, as línguas indígenas e, com a chegada dos escravos, também as línguas africanas ficariam no plano "cultural", enquanto caracterização antropológica que identifica povos diferentes e suas especificidades. $\mathrm{O}$ autor sintetiza suas conclusões afirmando que, para o Estado, a língua indígena é um elemento de museu ${ }^{37}$.

A respeito das questões mobilizadas, Rodrigues (2010, p. 44) esclarece, com base em

\footnotetext{
${ }^{34}$ Ibidem, p. 178.

${ }^{35}$ Ibidem.

${ }^{36}$ É relevante considerar que além das línguas dos indígenas e dos africanos, a partir de 1818, há, também, as línguas europeias, trazidas pelos imigrantes quando se inicia o processo de imigração para o Brasil. Segundo Guimarães (2005, p. 25), a relação do português com essas línguas europeias de imigração não poderia ser pensada da mesma maneira que sua relação com as línguas indígenas e africanas, isto é, língua de civilização (para o português) versus língua de cultura (para as indígenas e africanas) uma vez que, segundo o autor:

A diferença é o modo de relação. As línguas indígenas e africanas entram na relação como línguas de povos considerados primitivos a serem ou civilizados (no caso dos índios) ou escravizados (no caso dos negros). Ou seja, não há lugar para essas línguas e seus falantes. No caso da imigração, as línguas e seus falantes entram no Brasil por uma ação de governo que procurava cooperação para desenvolver o país. E as línguas que vêm com os imigrantes eram, de algum modo, línguas nacionais ou oficiais nos países de origem dos imigrantes. Essas línguas são línguas legitimadas no conjunto global das relações de línguas, diferentemente das línguas indígenas e africanas. As línguas dos imigrantes eram línguas de povos considerados civilizados, em oposição às línguas indígenas e africanas.
} ${ }^{37}$ Cf. GUIMARÃES, ibidem. 
Oliveira $^{38}$, que essa (re)organização da educação e, como mostramos aqui, também das línguas e de uma política linguística, proposta pelo Diretório dos Índios, foi oficializada por meio do Alvará de 28 de junho de 1759, que apresentava duas mudanças significativas: uma que estabelecia a criação de Aulas Régias em que professores eram selecionados, a partir de um processo oficial, e deveriam seguir um currículo e utilizar materiais indicados pelo Estado ao ministrar suas aulas; e outra que dividia os "Estudos Menores"39 em dois níveis: “o primeiro representado pelas Aulas Régias de Ler, Escrever e Contar em língua portuguesa e o segundo pela Gramática Latina, Grega, Hebraica e a Retórica. Essa divisão em níveis deu margem para que, em 1761, fossem criados os chamados "Colégios Nobres" em Lisboa, que agregaram ao segundo desses níveis algumas línguas vivas ${ }^{40}$, como o francês, o italiano e inglês (cf. RODRIGUES, 2010, p.45). Por fim, Rodrigues ${ }^{41}$ menciona que a permanência das línguas vivas nos currículos de ensino escolar foi reforçada pela reforma dos "Estudos Maiores"42, de 1772, na qual se passava a indicar o francês e o inglês como matérias recomendadas para ingresso no Curso Médico ${ }^{43}$.

Observamos, portanto, que no período colonial o panorama das línguas estrangeiras nas escolas brasileiras estava definido da seguinte maneira: havia cinco línguas estudadas nas escolas: três classificadas como clássicas (o latim, o grego e o hebraico) e duas classificadas como vivas (o inglês e o francês), com a possibilidade do estudo do italiano também. Assim

\footnotetext{
${ }^{38}$ A obra à qual Rodrigues (2010, p. 44) cita em sua pesquisa é: OLIVEIRA, L. E. (2002) Considerações sobre as figuras dos professores régios de línguas clássicas e modernas: notas para o estudo das origens da profissão docente no Brasil (1759 - 1809). In: Revista do Mestrado em Educação. Vol. 5, jan/2002. São Cristóvão: Universidade Federal do Sergipe, p. 103-124.

${ }^{39}$ Os "Estudos Menores" correspondem ao que, na atualidade, chama-se educação básica.

${ }^{40}$ É válido salientar que quando nos referimos a "línguas vivas" ou "línguas modernas", como aparecerá adiante, estamos sendo fiéis aos termos empregados nos referidos documentos oficiais e cujos excertos são apresentados nas pesquisas dos autores os quais citamos como referência.

${ }^{41}$ Ibidem.

${ }^{42}$ Os "Estudos Maiores" correspondem ao que, na atualidade, chama-se Ensino Superior.

${ }^{43}$ É mister esclarecer que segundo Rodrigues (ibidem, p. 45):

[...] apesar do lugar de destaque de que essas línguas passaram a desfrutar no ensino superior já no final do século XVIII, data apenas de 14 de julho de 1809 o documento legal que institui as primeiras cadeiras de francês e inglês para professores régios no Rio de Janeiro: a Decisão $\mathrm{n}^{\circ} 29$, assinada pelo rei D. João VI no período em que a corte portuguesa se estabeleceu no Brasil.
} 
sendo, é válido remeter à inferência de Picanço (2003, p. 28) de que, naquele contexto em que havia apenas poucas escolas privadas e os chamados Professores Régios, aos quais poucos tinham acesso, o ensino-aprendizagem de línguas estrangeiras era considerado como uma prática de erudição, a fim de formar a cultura de elite do país que almejava uma formação superior.

Retomando Rodrigues (2010, p. 47) e as considerações que essa autora faz com base nos estudos de Ribeiro ${ }^{44}$ (1978, p. 29), já na primeira metade do século XIX, após a vinda da família portuguesa para o Brasil e a independência do país, esse panorama começa a sofrer uma lenta reestruturação, uma vez que se criam as primeiras escolas públicas de ensino secundário: o Ateneu, fundado em 1825 no Rio Grande do Norte, os Liceus da Bahia e da Paraíba, de 1836, e o Collegio de Pedro Segundo, em 1837, no Rio de Janeiro. Rodrigues ${ }^{45}$ destaca ainda que, dentre essas três escolas, a que obteve maior relevância no contexto educacional brasileiro do período imperial foi o Collegio de Pedro Segundo, e Picanço ${ }^{46}$ justifica esse fato com base em um outro: o de que essa instituição de ensino foi a primeira escola pública de nível médio e que passou a ser modelo para as demais de nível secundário com relação a uma uniformização dos conteúdos e das disciplinas.

O currículo do Collegio de Pedro Segundo, por ser baseado no ensino clássico e humanista do modelo francês, incluía, em 1838, à semelhança da proposta do Diretório dos Índios, duas línguas clássicas (o latim e o grego) e duas línguas modernas (o francês e o inglês), sendo cada uma das modernas estudada por dois anos: o inglês no $3^{\circ}$ e $4^{\circ}$ e o francês no $4^{\mathrm{o}}$ e $5^{\mathrm{o} 47}$. Com base nessa pesquisa, Rodrigues ${ }^{48}$ conclui que a presença dessas línguas estrangeiras na grade curricular do Collegio de Pedro Segundo representava uma legitimação

\footnotetext{
${ }^{44}$ A obra de Ribeiro a qual Rodrigues (2010, p. 47) mobiliza é: RIBEIRO, M. L. S. (1978). História da educação brasileira: a organização escolar. São Paulo: Cortez\&Moraes.

${ }^{45}$ Ibidem.

${ }^{46}$ Ibidem.

${ }^{47}$ Cf. RODRIGUES, ibidem, p. 49.

${ }^{48}$ Ibidem., p. 51
} 
destas como disciplinas e, a partir de sua conclusão, retoma e corrobora a inferência proposta por Souza ${ }^{49}$ segundo a qual "a fundação da noção de língua estrangeira no imaginário brasileiro iniciou-se no período imperial”, uma vez que no currículo disciplinar opunham-se, “de maneira oficial”, essas línguas à língua tida como nacional, o português. A respeito desse momento de legitimação das disciplinas, principalmente das línguas estrangeiras, Rodrigues (2010, p. 52) salienta, ainda, o decreto de N. 62 de $1^{\circ}$ de fevereiro de 1841, a partir do qual se inseriu o estudo do alemão em caráter obrigatório.

Dando continuidade à análise de decretos relacionados ao ensino de línguas estrangeiras nas escolas brasileiras, a autora $^{50}$ enfoca o de N. 981, de 1890, assinado aproximadamente um ano após a Proclamação da República pelo General Manoel Deodoro da Fonseca. Esse documento regulava o ensino primário e secundário no Distrito Federal naquele momento a cidade do Rio de Janeiro -, porém, como o Collegio de Pedro Segundo (que a partir desse decreto passou a chamar-se Gymnasio Nacional) era a única instituição pública de ensino secundário a ser mantida e regida pelo governo nacional, reforçou-se a prática que havia se instaurado desde sua criação no período imperial: de tomá-lo como modelo a ser seguido não apenas por instituições do DF para esse nível de ensino, mas também por quaisquer instituições públicas ou privadas dos demais Estados do país. A respeito das línguas estrangeiras, esse decreto inseriu o estudo de uma língua estrangeira - o francês - também no nível primário e dispôs que, ao longo dos sete anos do nível secundário, essa língua seria de estudo obrigatório nos três primeiros anos e, no $3^{\circ}, 4^{\circ}$ e $5^{\circ}$ anos os alunos poderiam escolher também entre o inglês ou alemão. Logo, essas duas línguas, que antes eram de estudo obrigatório, passam a optativas, restando apenas o francês com o estatuto de obrigatoriedade. 
Com relação às reformas subsequentes ${ }^{51}$, ocorridas entre 1892 e 1925 , Rodrigues ${ }^{52}$ faz apenas uma menção a fim de enfatizar que o lugar das línguas estrangeiras na escola e nos documentos jurídicos continuou sofrendo alterações e instabilidades. Nesse sentido, a partir das análises que apresentamos, com base fundamentalmente na pesquisa realizada por essa autora, concluímos que a série de reformas, ocorridas na educação brasileira, seguiu a tendência de um movimento que podemos designar, num primeiro momento, como de vai-evem em relação às línguas estrangeiras e à sua presença/ausência nos currículos escolares até o ano de 1925. De fato, por efeito do político (cf. GUIMARÃES, 2005, p. 15-19 ${ }^{53}$ ), estamos diante de movimentos de inclusão e de exclusão na grade curricular, que envolveram, ainda, o aumento e a diminuição do tempo de estudo e a alteração do caráter de obrigatório para optativo ou facultativo e vice-versa pelos quais essas línguas passaram ao longo das reformas materializadas juridicamente nos decretos que apresentamos. Em meio a esse jogo de forças que implica movimentos de inclusão e exclusão, no ano de 1929 o quadro de disciplinas oferecia quatro, em vez de duas línguas estrangeiras. Conforme Picanço (2003, p. 28) em grau de importância e número de anos de estudos, o francês figurava em primeiro lugar, seguido do inglês - ambos em caráter obrigatório - e, em caráter optativo, o alemão e o italiano que fora inserido em 1929 e permaneceu no currículo oficial até 1931. Entretanto, outra reforma ocorrida nesse mesmo ano, determinará novas mudanças com relação às línguas estrangeiras na grade curricular das escolas brasileiras.

Segundo Rodrigues (2010, p. 63), é com Getúlio Vargas no poder que ocorrem essas novas mudanças que a autora considera significativas na educação nacional. Tais alterações são produzidas pela chamada Reforma Francisco de Campos, materializada pelo Decreto N. 19.890 (de 18 de abril de 1931), e, também, pela criação de um Ministério da Educação e

\footnotetext{
${ }^{51}$ As referidas reformas ocorreram, respectivamente, conforme Rodrigues (ibidem, p. 62) em 1892, 1898, 1901, 1911,1915 e 1925.

${ }^{52}$ Ibidem, p. 62

${ }^{53}$ Esclarecemos que para trabalhar o conceito de político, Guimarães (ibidem) mobiliza as interpretações de Rancière na filosofia, a partir da seguinte obra: RANCIÈRE, J. (1005) La mésentente. Paris, Galilée.
} 
Saúde Pública. A autora justifica a relevância dessa Reforma a partir dos estudos de Zotti ${ }^{54}$, que consideram esse texto jurídico como um marco do início do processo de centralização da educação por parte do governo. Esse decreto, conforme interpreta Rodrigues ${ }^{55}$, dividiu o ensino em duas etapas: uma chamada fundamental, com cinco anos de duração; e outra chamada complementar, com dois anos de duração e com ênfase em áreas específicas (jurídica, medicina, farmácia, etc.). Esta segunda etapa era considerada obrigatória para aqueles que desejassem cursar o ensino superior.

Na etapa fundamental, legitimavam-se três línguas estrangeiras: o francês (com duração de estudo de quatro anos), o inglês (com duração de estudo de três anos) e o alemão (em caráter facultativo, e com duração de estudo de dois anos). Já na etapa complementar, o francês deixava de ser uma língua de estudo obrigatório, permanecendo apenas o inglês ou o alemão e somente em áreas relacionadas à medicina ${ }^{56}$. Picanço (2003, p. 28) acrescenta, ainda, que é neste período que o italiano, antes língua de ensino facultativo, deixa de integrar o currículo oficial escolar.

Mais de dez anos após a reforma de 1931 e ainda sob o governo de Vargas, Rodrigues $^{57}$ analisa a publicação de um novo decreto, em 1942, chamado também de Lei Orgânica do Ensino Secundário que fez parte da Reforma Capanema, conduzida pelo Ministro de Educação e Saúde, Gustavo Capanema. Esse ministro reestruturou a educação nacional da seguinte maneira:

[...] os níveis escolares passaram a se dividir em Primário - que compreendia os primeiros anos de escolaridade das crianças, dos 7 aos 11 anos - e Secundário. Este último continuava partido em dois ciclos: o primeiro, denominado ginasial, que se seguia ao primário, tinha quatro anos de duração; o segundo possuía três anos de duração e dividia os estudantes de acordo com suas preferências acadêmicas entre os cursos clássico e

\footnotetext{
${ }^{54}$ A obra de Zotti referida por Rodrigues é: ZOTTI, S. A. (2006). O ensino secundário nas Reformas Francisco Campos e Gustavo Capanema: um olhar sobre a organização do currículo escolar. In: Anais do IV Congresso Brasileiro de História da Educação. Goiânia: Universidade Católica de Goiás / SBHE. Disponível em: <www.sbhe.org.br/novo/congressos/cbhe4/individuais-coautorais/eixo01.htm> Acesso em: 22 jan. 2011.

${ }^{55}$ Ibidem., p. 65.

${ }^{56}$ Cf. RODRIGUES, ibidem.

${ }^{57}$ Ibidem p. 71.
} 
científico (RODRIGUES, 2010, p. 71).

Assim sendo, conforme a pesquisadora ${ }^{58}$, no período ginasial oferecia-se o francês durante os quatro anos e o inglês durante três. E, no segundo ciclo, dividido de acordo com a área de interesse acadêmico dos discentes, oferecia-se o francês ou o inglês, por dois anos, aos que cursassem a modalidade clássica e científica. Como diferencial, as línguas clássicas, latim e grego, poderiam ser cursadas apenas pelos discentes do curso clássico e, pela primeira vez, o espanhol passa a ser oferecido, por um ano, aos que cursassem ambas as modalidades.

A esse respeito, ou seja, a inclusão da língua espanhola, pela primeira vez, no currículo escolar mediante um documento jurídico, consideramos válido atentar para duas interpretações que formulamos. A primeira é a de que pelo fato de tal documento legislar sobre a educação, podemos considerar que essa inclusão da língua espanhola pela primeira vez, estende-se ao espaço escolar. E, a segunda, é a de que a inclusão da LE, tanto nos documentos jurídicos quanto no espaço da escola, ocorreu concomitante à exclusão da língua alemã, que esteve presente em ambos desde 1841, ainda que com um caráter oscilante entre obrigatório, optativo e facultativo. No tocante às interpretações formuladas, passamos a entender que tal exclusão, produzida na materialidade linguística do documento jurídico e estendida ao espaço de enunciação escolar, representa um gesto de política linguística resultante das condições históricas de relações entre línguas num dado momento (cf. MARIANI, 2004, p. 44). Impulsionados por essa compreensão, consideraremos a exclusão do alemão como um elemento relevante em meio às condições de produção da inserção da língua espanhola no currículo das escolas brasileiras.

Para entender essa relação que estabelecemos entre a exclusão do alemão e a inserção do espanhol bem como a relevância que atribuiremos a mesma, é válido recorrermos aos estudos de Eckert-Hoff (2010). Essa pesquisadora, ao estudar a imigração alemã no Brasil, em especial a ocorrida na região sul do país, constata algumas especificidades das colônias ${ }^{58}$ Ibidem. 
alemãs que as diferenciariam de outras colônias de imigrantes e que conferiram ao alemão algumas singularidades enquanto "língua estrangeira e de imigração 59 ", não observadas com relação a outras línguas também "estrangeiras e de imigração" naquele período. Com base em sua pesquisa, a autora ${ }^{60}$ conclui que os alemães vieram "em busca da terra prometida" na ilusão de que tudo o mais se manteria, uma vez que já estava constituído o imaginário de uma migração para uma "Nação sem dono", que era o Brasil. O fato de projetar o Brasil como uma "Nação sem dono" lhes permitiria propagar a língua, a cultura, enfim, como conclui EckertHoff $^{61}$, continuar alemães.

A pesquisadora ressalta ainda, com base nos estudos de Magalhães ${ }^{62}$, que para manter esse imaginário e preservar a identidade religiosa cultural e linguística, os imigrantes alemães, diferentemente dos europeus italianos - que imediatamente matricularam seus filhos nas escolas brasileiras - criaram suas próprias escolas, igrejas e sua própria literatura. Nesse sentido, Eckert-Hoff (2010, p. 87) destaca que a criação de suas próprias escolas e da própria literatura propiciou que os alemães se fechassem em colônias e propagassem a língua e a cultura germânica.

A partir da pesquisa realizada por essa autora, podemos compreender como a imigração alemã se diferenciou no Brasil de outras imigrações, fundamentalmente, devido à propagação de um sentimento de "nacionalismo alemão" que, segundo outros estudos citados e que servem de fundamento ao trabalho de Eckert-Hoff $^{63}$, denomina-se Deutschtum ou Volksgemeinschaf e que engloba a língua, a cultura, o Geist (espírito) alemão e a lealdade à Alemanha enquanto nação e não como um Estado.

\footnotetext{
${ }^{59}$ Consideramos o termo língua estrangeira - ao menos neste contexto de análise do arquivo jurídico - como já o apresentamos neste trabalho em nota de rodapé anterior, ou seja, referente às outras línguas que não são a língua considerada oficial/nacional pelo Estado.

${ }^{60}$ Ibidem, p. 87

${ }^{61}$ Ibidem.

62 A pesquisa de Magalhães citada por Eckert-Hoff é: MAGALHÃES, Marionilde Brepohl de (1998). Pangermanismo e Nazismo: a trajetória alemã rumo ao Brasil. Campinas: UNICAMP. São Paulo: FAPESP.

${ }^{63}$ Ibidem, p. 88
} 
Ante esse panorama, a pesquisadora também destaca, com base nos estudos de Seyferth $^{64}$, que, nas décadas de 30 e 40 do século XX, quando os jornais europeus denunciavam o grande número de alemães no Sul do Brasil, alertando que Hitler poderia tomar as terras porque seria apoiado pela população germânica que habitava as colônias alemãs, e quando Getúlio Vargas ascende ao poder e instaura uma política de nacionalismo, inicia-se um período de forte repressão e violência aos imigrantes alemães e às colônias que eles haviam organizado. Vargas, segundo as pesquisas de Souza (2005, p. 130), buscava instituir a "moderna nação brasileira" e para isso era imprescindível a atuação na área da educação, cada vez mais vista como um fator importante para o desenvolvimento do país, ainda que de forma inconsciente. Ainda no tocante à atuação do então presidente do Brasil na área educacional, Souza ${ }^{65}$ evidencia, dentre as políticas linguísticas praticadas por esse governo, dois tipos em especial: um que ele denomina como "política de infusão" e define como a implementação de ações voluntariosas cuja intenção era forçar nas pessoas a assimilação de um "espírito de brasilidade"; e outro que denomina como "política de silenciamento" e define, com base em Orlandi ${ }^{66}$ (1995), como caracterizado por uma violenta repressão linguística e cultural. Para apresentar o funcionamento dessas políticas, Souza (2005, p. 130) cita afirmações de Müller de Oliveira ${ }^{67}$ :

O regime ditatorial de Getúlio Vargas marca o ponto alto da repressão às línguas alóctones, através do processo que ficou conhecido como "nacionalismo do ensino" e que pretendeu selar o destino das línguas de imigração no Brasil, especialmente o do alemão e do italiano na região colonial de Santa Catarina e do Rio Grande do Sul. Nesses dois estados, a repressão linguística atingiu sua maior dimensão através do conceito jurídico

\footnotetext{
${ }^{64}$ A obra de Seyferth que Eckert-Hoff (2010, p.88) cita é: SEYFERTH, Giralda (1982). Nacionalismo $e$ identidade étnica: a ideologia germanista e o étnico Teuto-Brasileiro numa comunidade no Vale do Itajaí. Florianópolis: FCC.

${ }^{65}$ Ibidem, p. 131-135.

66 A obra de Orlandi citada por Souza corresponde à mesma que apresentamos em nossas Referências Bibliográficas, cuja data de publicação é de 1992.

${ }^{67}$ A obra de Müller de Oliveira citada por Souza é: MÜLLER OLIVEIRA, G. (2000) Brasileiro fala português: monolinguismo e preconceito linguístico. In: MOURA E SILVA (Org.). O direito à fala: a questão do preconceito linguístico. Florianópolis: Editora Insular.
} 
de "crime idiomático ${ }^{68,}$, inventado pelo Estado Novo.

Souza (2005, p. 132) enfatiza, ainda, que os redutos formados pela população de origem germânica a partir do século XIX, devido ao expressivo número de pessoas, à importância da imprensa étnica e às manifestações intensas e ostensivas de germanidade, associaram-se a um imaginário chamado de "perigo alemão". Sendo assim, explica que ante a esse imaginário que se fortalecia, Vargas implementou, em 25 de agosto de 1939, um Decreto-Lei N. 1545 que dispunha sobre a adaptação no meio nacional dos brasileiros descendentes de estrangeiros ${ }^{69}$. Dentre as determinações desse Decreto, consideramos pertinente destacar o item "e" do artigo $4^{\circ}$ referente às incumbências do Ministério da Educação e Saúde que deveria "exercer vigilância sobre o ensino de línguas e da história e geografia do Brasil” (apud SOUZA ${ }^{70}$ grifos nossos).

É, portanto, em meio a essas condições que a língua alemã passa a ser proibida não só nas colônias do Sul do Brasil, onde existiam escolas, jornais, livros, igrejas alemãs, mas também em nível nacional, como uma disciplina que era ensinada nas escolas regulares como língua estrangeira e em caráter facultativo.

Com base na série de aspectos que colocamos em relação a partir dos estudos que mobilizamos, podemos observar o funcionamento da exterioridade como historicidade na materialidade do texto jurídico sob a forma de um não-dito e, assim, compreender não apenas a exclusão do alemão, mas, também, o movimento de inclusão do espanhol. Essa língua, embora também pudesse ser associada a um país que adotara um regime ditatorial fascista naquele mesmo período (de 1936 a 1975, desde o início da Guerra Civil espanhola até a

\footnotetext{
${ }^{68}$ Segundo as reflexões desenvolvidas por Souza (ibidem) e associadas à citação de Müller de Oliveira, o "crime idiomático" seria entendido como o conjunto de ações de repressão linguística e cultural praticadas para torturar aqueles que falassem sua língua materna.

${ }^{69}$ Cf. SOUZA, ibidem.

${ }^{70}$ Ibidem.
} 
ascensão do general Francisco Franco ${ }^{71}$ ), não se expressava no Brasil por meio da imigração com a mesma força de nacionalismo que a língua alemã apresentava. Ou seja, a língua espanhola não estava configurada, no Brasil, a partir de uma comunidade de imigração, estruturada com instituições, língua, valores e costumes próprios que se diferenciavam da sociedade brasileira, ao menos não da forma como se observava com a imigração alemã e com a sua língua. Provavelmente, esse aspecto favoreceu o fato de que a LE não se filiasse a sentidos de nazismo ou totalitarismo, não representando, assim, um "perigo" ao nacionalismo.

O espanhol, por sua vez, vinculava-se a sentidos de uma língua de cultura notável e de acesso a uma riqueza de produções bibliográficas, conforme podemos perceber a partir de uma sequência ${ }^{72}$ da Exposição de Motivos da Reforma Capanema de 1942, que é o documento que justifica a inclusão da língua espanhola no currículo oficial brasileiro:

EMRC_a:[...] além de ser uma língua de antiga e vigorosa cultura e de grande riqueza bibliográfica para todas as modalidades de estudos modernos, é o espanhol a língua nacional do maior número dos países americanos. (INEP $^{73}, 1952$, p. 26 apud CAMPOS, 2006, p. 4897, grifo nosso).

A esse fragmento, associamos a formulação de Picanço (2003, p. 33) que, com base em suas pesquisas, acrescenta que, naquela época, o espanhol no Brasil se vinculava a sentidos de língua de autores consagrados, como Cervantes e Lope de Vega, e de língua associada a heróis nacionais como El Cid, a Rainha Isabel, o Imperador Carlos V e os conquistadores. O primeiro desses sentidos, relacionado a uma riqueza bibliográfica e que

\footnotetext{
71 Conforme Casanova (2000, p. 339-343), um historiador, a construção do novo Estado Espanhol foi acompanhada pela eliminação física do oponente e pela destruição de todos os símbolos e políticas da República. Ademais, Franco contou com o apoio e bênção da Igreja Católica que começou a tratá-lo como um enviado de Deus. Seu primeiro objetivo era criar um comando militar único e um aparelho político centralizado e as autoridades do Terceiro Reich negociavam com Franco o empréstimo de materiais de guerra pressionando-o para que ele tomasse as rédeas e instaurasse um regime ditatorial fascista. Hitler e Mussolini ajudaram Franco com empréstimo de diversos materiais de guerra e Mussolini foi também quem enviou, em fevereiro de 1937, um representante, Roberto Farinacci, das posições mais radicais e violentas para orientar Franco na criação de um Partido Nacional Espanhol com um autêntico programa fascista e corporativo.

${ }^{72}$ As sequências que apresentaremos do referido documento jurídico serão indicadas pela sigla composta pelas iniciais de seu título, Exposição de Motivos da Reforma Capanema, acompanhadas por letras do alfabeto, em minúscula, a fim de ordená-las.

${ }^{73}$ Ensino Secundário no Brasil: organização, legislação vigente, programas. Rio de Janeiro: INEP, $1952, \mathrm{n}^{\circ} 67$.
} 
aparece tanto na Exposição de Motivos da Reforma Capanema como nas inferências de Picanço $^{74}$, pode ser identificado também na entrevista que realizamos a González ${ }^{75}$, no fragmento em que declara:

SdG_a: [...] E, depois, já no ginásio mesmo, a gente tinha que fazer pesquisas na biblioteca e muitas das coisas que a gente tinha que pesquisar estavam escritas em espanhol. Eu me lembro de ter feito, desde muito cedo, já na terceira ou quarta série da época, leituras de livros em espanhol para fazer trabalhos da escola. (linhas 31-35, grifos nossos).

Com base no que relata González, podemos inferir que, naquele período, textos ou obras que serviam de bibliografia na escola ainda não estavam traduzidos em língua portuguesa. O que nos parece interessante é observar como estava pressuposta e naturalizada a leitura nessa língua (inclusive de bibliografia consultada na biblioteca) e por alunos de terceira ou quarta série sendo que o ensino de espanhol, na época, não era ofertado no ciclo ginasial ao qual se refere González. Neste, como já expusemos com base na reorganização da educação promovida pela Reforma Capanema, os alunos estudavam apenas o francês e o inglês. Sendo, assim, entendemos que o fato de que eles recorressem à bibliografia escrita em espanhol, língua que não estudavam, vincula-se não apenas "a grande riqueza bibliográfica" segundo consta no texto jurídico - dessa língua, mas também a um pré-construído segundo o qual essa língua era transparente, fato que, de nossa perspectiva, alimentava o imaginário de semelhança com o português e, também, de facilidade (cf. CELADA, 2002) ${ }^{76}$.

Ainda com relação à sequência EMRC_a, do documento jurídico que estamos analisando e que colocamos em relação com os estudos de Picanço (2003) e com a entrevista

\footnotetext{
${ }^{74}$ Ibidem.

75 Como já indicamos na Introdução desta dissertação, a entrevista realizada com a profa. González está transcrita no anexo B deste trabalho e as normas utilizadas para a mesma estão disponíveis no anexo A. Ademais, indicaremos as sequências discursivas que recortamos desta entrevista pela sigla Sd acompanhada da inicial do sobrenome da entrevistada, G, acompanhado de uma letra do alfabeto, em minúscula, para ordená-las.

${ }^{76}$ Essa interpretação será aprofundada no Capítulo 2, a partir da análise da apresentação da Gramática de Nascentes. Com base na interpretação realizada por Celada (2002), este instrumento configura-se como um discurso que "fundou" os sentidos sobre a língua espanhola no Brasil, recuperando-os a partir de um senso comum e legitimando-os em uma obra. Dentre esses sentidos, destacam-se, como mostraremos, os de semelhança entre o espanhol e o português e o de suposta facilidade, fundamentalmente em relação à leitura e à compreensão.
} 
a González, consideramos válido retomar o último enunciado que ressaltamos, ou seja, o de que o espanhol é "a língua nacional do maior número de países americanos”, e vinculá-lo aos sentidos que aparecem em outra sequência da referida Exposição:

EMRC_b:[...] adotá-lo no nosso ensino secundário, estudá-lo, não pela rama e autodidaticamente, mas de modo metódico e seguro, é um passo a mais que damos para a nossa maior e mais íntima vinculação espiritual com as nações irmãs do continente (INEP, 1952, p. 26 apud CAMPOS, 2006, p. 4897, grifo nosso).

A primeira reflexão que formulamos, a partir da sequência acima e do enunciado da EMRC_a que retomamos, refere-se à interpretação de que, de nossa perspectiva, a língua espanhola está sendo significada, nesse discurso jurídico, muito mais em relação aos países hispanofalantes da América do que à Espanha. Identificamos tal sentido nos fragmentos "países americanos" e "nações irmãs" (respectivamente da EMRC_a e da EMRC_b). O primeiro deles remete à América de maneira explícita, isto é, pela própria materialidade da língua. Já o segundo projeta, a partir do termo "irmãs", sentidos que estão vinculados imaginariamente aos laços entre os países da América colonizados por Nações ibéricas, mais especificamente, pela Espanha e por Portugal ${ }^{77}$. Ademais, conforme a análise que já apresentamos neste item, podemos entender esse gesto de relacionar a LE, explicitamente, aos países hispano-americanos (e não à Espanha) como um gesto que materializa o posicionamento do então governo Vargas: evitar relações com os países europeus submetidos e/ou vinculados a regimes nazifascistas que pudessem ameaçar a "política de brasilidade" que esse presidente propagava ${ }^{78}$.

Ademais das reflexões que formulamos com base na EMRC_b, outro aspecto que nos chama a atenção de maneira especial, nessa sequência da Exposição, é a negação que

\footnotetext{
${ }^{77}$ As discursividades relacionadas aos dizeres de "irmandade", bem como aos sentidos que as mesmas projetam, serão retomadas e aprofundadas no Capítulo 3 desta dissertação, com base na pesquisa de Rodrigues (2010).

${ }^{78}$ Consideramos necessário observar que a Espanha, embora não estivesse dentre os principais países europeus antecipados como potenciais ameaças pelo/ao governo Vargas, estava sob o regime ditatorial de Franco, que como já mencionamos, com base em Casanova (2000, p. 339-343), mantinha relações políticas com os governos nazifascistas da Alemanha e da Itália.
} 
destacamos e a substituição que se produz mediante o operador argumentativo "mas": "não pela rama e autodidaticamente, mas de modo metódico e seguro" ${ }^{79}$. Direcionamos nosso olhar para esse enunciado por dois motivos. O primeiro seria pelo fato de que a expressão "pela rama", neste texto, parece entrar em relação com os seguintes sentidos: "de maneira superficial" ou "sem aprofundamento". O segundo é que, a partir dessa negação, associada ao fragmento adversativo introduzido pelo operador "mas", identificamos que a mesma parece negar um sentido: o de que o espanhol poderia ser estudado de maneira superficial e com a "espontaneidade" e "informalidade" de um autodidata. Essas duas observações nos permitem inferir que esse sentido, provavelmente, funcionasse como um pré-construído naquele espaço de enunciação.

Essas inferências suscitadas a partir da análise que fazemos da sequência EMRC_b da Exposição podem ser reforçadas com base em afirmações realizadas por González, na referida entrevista. Ao lhe perguntarmos sobre a existência de algum contato com a língua espanhola antes desta ter se tornado uma disciplina oficial nas escolas brasileiras, a estudiosa responde:

SdG_b: Eu tive sim e de várias formas. Primeiro, eu cheguei a ouvir bastante espanhol com vizinhos que eram imigrantes. Inclusive eu tive uma amiga muito próxima que era filha de um espanhol e a mãe era nascida na Argentina, mas filha de espanhóis também. Então, eu tive contanto com o espanhol assim, nessa espontaneidade, ouvindo músicas porque, na época, as músicas faziam bastante sucesso. (linhas 27-31, grifos nossos).

Associando essa resposta a fatos que já apresentamos aqui, ponderamos que, diferentemente das outras línguas de imigração com forte presença na sociedade brasileira da época - a saber: o alemão, o italiano -, o espanhol era a única que ainda não tinha feito parte dos currículos oficiais. Com base no que González relata, identificamos indícios de que, naquela época, a língua espanhola estava presente no espaço de enunciação brasileiro, porém o contato com a mesma estava marcado pela relação com a imigração, com "as músicas cantadas em espanhol" e com leitura de bibliografias escritas nessa língua. Nesse sentido,

\footnotetext{
${ }^{79}$ Cf. INEP, 1952, p. 26 apud CAMPOS, 2006, p. 4897.
} 
entendemos que, no espaço do real, a relação com a língua espanhola se dava, como afirma a própria González, "nessa espontaneidade”, ou seja, não se pressupunha a necessidade de conhecer essa língua para relacionar-se com ela, ao menos no que diz respeito à comunicação oral (conversar com vizinhos e amigos), à compreensão auditiva (ouvir músicas em espanhol) e à leitura (ler livros escritos em espanhol). Isso nos leva a considerar que essa "relação de espontaneidade" do brasileiro com a LE fazia parte das condições de produção do discurso da Exposição de Motivos da Reforma Capanema e está materializada na textualidade do mesmo a partir do enunciado que, a respeito do ensino de espanhol no nível secundário, salienta a importância de "estudá-lo, não pela rama e autodidaticamente, mas de modo metódico e seguro".

O trabalho de análise realizado com relação a esse fragmento da Exposição de Motivos da Reforma Capanema remete-nos, por sua vez, ao que Courtine (2009, p. 90), a partir das reflexões que realiza com base na obra Arqueologia do Saber, de Foucault, caracteriza como memória do enunciado. Segundo Courtine ${ }^{80}$, o "domínio associado" a um enunciado (ou a memória deste), vincula-se a uma ordem de formulações com as quais entram em relação o eixo horizontal do intradiscurso e o vertical, do interdiscurso. Nesse sentido, se nos centramos na negação do enunciado que destacamos - "não pela rama e autodidaticamente" -, podemos detectar como a mesma entra em relação com o interdiscurso, uma vez que nela ressoa, como retomaremos no Capítulo 2, outra negação presente na Gramática de língua espanhola para uso dos brasileiros de Antenor Nascentes, de 1934, já identificada e analisada na pesquisa de Celada (2002, p. 64), a saber: "é de grande vantagem para os brasileiros o conhecimento não perfunctório" do espanhol (NASCENTES, 1939, p. 4 - grifos nossos). Observamos que esta negação (“conhecimento não perfunctório”) parece trazer à luz sentidos de forte cristalização, na memória que se organizava sobre a língua espanhola no espaço de enunciação brasileiro e

\footnotetext{
${ }^{80}$ Ibidem.
} 
naquelas condições de produção. Ademais, interpretamos que tais sentidos associavam o espanhol ao imaginário de uma língua cujo estudo e conhecimento poderia dar-se de maneira superficial, sem uma sistematização ou disciplinarização vinculada ao âmbito escolar, ou, ainda que nesse âmbito, pudesse ocorrer de maneira autodidata.

Ainda com relação ao conceito de Courtine (2009), é válido analisar como o enunciado do texto jurídico da Exposição de Motivos da Reforma Capanema entra em relação também com o eixo horizontal do intradiscurso. Para tanto, é necessário que apresentemos outra sequência do mesmo:

EMRC_c: [...] o ensino secundário das nações cultas dá em regra a cada aluno o conhecimento de uma ou duas línguas vivas estrangeiras. Esse número é elevado a três pelos países cuja língua nacional não constitui um instrumento de grandes recursos culturais. A reforma adotou esta última solução (INEP, 1952, p. 26 apud CAMPOS, 2006, p. 4897, grifo nosso).

Com base na sequência recortada, podemos interpretar que deveria ser oferecido o ensino de, pelo menos, três línguas estrangeiras, visto que a língua nacional, o português, não apresentava "grandes recursos culturais". Assim sendo, com a exclusão do alemão, o lugar dessa terceira língua precisava ser preenchido por outra que cumprisse uma dupla função: por um lado, "completar" a estatística de três línguas estrangeiras e, por outro, "complementar" a “carência de recursos culturais" produzidos ou disponíveis em língua portuguesa.

Portanto, de nossa perspectiva, a língua espanhola se associa, duplamente, ao sentido do que denominaremos de "complemento"; e, a partir dessa inferência, podemos compreender por que, segundo Rodrigues (2010, p. 78), na Reforma Capanema ela não foi, como as outras línguas estrangeiras, inserida na etapa de formação geral, que seria a ginasial, mas sim na etapa secundária em que os estudos eram direcionados à área acadêmica pretendida. Ou seja, conseguimos entender a afirmação da referida autora de que essa língua foi inserida nos cursos clássicos e científicos mesmo sem vincular-se, imaginariamente e naquele contexto, a nenhuma dessas áreas de conhecimento, uma vez que esta se associava ao sentido de 
“complemento" e não de necessidade, de relevância ou de coerência com a área de estudo.

Ademais, o fato de ter sido inserida por apenas um ano, contribuía para que esses sentidos de "complemento" e de "não relevância ou necessidade" fossem reforçados, conforme podemos interpretar também com base na resposta dada por González quando questionada a respeito da relação que os demais alunos tinham com o estudo da língua espanhola na escola:

SdG_c: Todo mundo achava, em princípio, mais fácil porque todos tinham tido algum tipo de contato com essa língua, fosse pela vizinhança, fosse pela família ou fosse por essa necessidade que, muitas vezes, a gente tinha de fazer pesquisas utilizando livros escritos em espanhol ou livros traduzidos para o espanhol, que eram mais acessíveis. Havia mais traduções de obras de referência ao espanhol do que ao português. Eu realmente não me lembro de ninguém questionar as aulas que, como eu disse a você, eram divertidas. Eram as aulas em que a gente mais relaxava porque o grau de compromisso era pequeno, já que sabíamos que eram apenas por um ano. Então, era uma disciplina que tínhamos que dar conta para passar de ano. Não era uma coisa comum da época você entrar em grandes questionamentos, "Por que está?", "Por que tem isso?". Fazia parte do currículo e todo mundo aceitava e estudava para passar. Agora, a respeito da relação com a língua, sempre foi isso: era uma língua muito parecida, a gente pensava em dar conta dela e, claro, como era por apenas um ano, também não chegávamos a um grau de aprofundamento. Quero dizer, nunca tivemos nenhuma exigência como, por exemplo, de falar em espanhol ou de escrever textos. Tínhamos apenas que ler, entender, repetir algumas coisas e fazer os exercícios. Você não percebia nenhum objetivo como: você vai ter que, ao final desse ano, estar falando espanhol muito bem ou estar escrevendo muito bem. Não, não tinha isso. (linhas 86-103, grifos nossos)

Mobilizamos esse recorte da entrevista realizada a González, a partir das reflexões que formulamos ao colocar a sequência da Exposição de Motivos da Reforma Capanema (EMRC_c) em relação de sentidos com um aspecto específico das condições de produção da LE - a exclusão da língua alemã da grade curricular - no período em que este documento jurídico foi publicado. A esse respeito, consideramos pertinente retomar o referido aspecto a fim de aprofundar a compreensão desses movimentos de inclusão/exclusão do espanhol e do alemão, respectivamente, com base no entendimento de que os dizeres sobre ambas as 
línguas, circulavam no que Guimarães (2005, p. 18-19) define como espaço de enunciação ${ }^{81}$ :

[...] espaços de funcionamento de línguas, que se dividem, redividem, se misturam, desfazem, transformam por uma disputa incessante. São habitados por falantes, ou seja, por sujeitos divididos por seus direitos ao dizer e aos modos de dizer.

Esse autor acrescenta, ainda, que esse espaço ao qual se refere é um espaço político ${ }^{82}$ e explica esse conceito como um conflito entre uma divisão normativa e desigual do real (que em nossas análises, consideramos como a divisão desigual, pautada em textos normativos jurídicos, entre línguas que deveriam e que não deveriam pertencer ao currículo escolar brasileiro) e uma redivisão pela qual o que não pertence, ou não está incluído, afirma seu pertencimento (em nosso caso, o que observamos com o ocorrido com a língua espanhola: até 1941 excluída das disciplinas oficiais e a partir do ano seguinte inserida entre elas). Nesse sentido, chegamos a uma conclusão que, de nossa perspectiva, caracteriza-se como reveladora para nosso trabalho e que nos trará contribuições importantes: no espaço de enunciação brasileiro, essa "disputa incessante" entre as línguas, a qual Guimarães (2005, p. 18-19) se refere e, no caso específico que estamos analisando, entre as línguas estrangeiras, está materializada discursivamente pelos movimentos de inclusão (do espanhol) / exclusão (do alemão). Movimentos estes que detectamos, em nossa pesquisa, a partir dos documentos jurídicos que analisamos até o momento e, fundamentalmente, da Exposição de Motivos da Reforma Capanema de 1942. Em outras palavras, compreendemos que, em meio ao funcionamento da memória discursiva sobre a LE no Brasil, seu pertencimento só ocorreu a partir do não pertencimento de outra língua que, naquela situação, devido às condições de produção que já abordamos, foi o alemão.

Neste ponto, recuperando o que acabamos de observar, podemos associar os sentidos projetados pela materialidade linguística do documento jurídico que analisamos sobre a

\footnotetext{
${ }^{81}$ Já mobilizamos esse conceito ao longo deste trabalho (inclusive, também, o fizemos com relação ao "político", tal como Guimarães o interpreta a partir de Rancière - como já citamos em nota anterior); no entanto, neste ponto, consideramos que é momento de apresentá-lo de modo explícito.

${ }^{82}$ Cf. GUIMARÃES, ibidem., p. 17.
} 
inclusão da língua espanhola na escola, a saber - "língua de antiga e vigorosa cultura”, "de grande riqueza bibliográfica", "de maior número de países americanos" e "de vinculação espiritual ao Brasil" -, aos sentidos que aqui identificamos e que estão no "não dito" dos textos jurídicos, mas que podemos recuperar discursivamente (pelas relações de sentido com as condições de produção):

a) o fato de ter sido incluída oficialmente nas escolas brasileiras a partir da exclusão de outra língua estrangeira, o alemão;

b) o fato de essa inclusão ter ocorrido para completar um número de línguas a ser preenchido e para complementar a "carência de recursos culturais em língua nacional".

Mediante essa associação, percebemos que se configura uma série de sentidos (cf. PÊCHEUX, 1999, p. 52) que se vinculam de maneira contraditória, principalmente, se considerarmos o sentido do pré-construído negado, segundo o qual a língua espanhola estaria relacionada a não-necessidade de estudo formal e ao impulso e à prática espontâneos de um autodidata. Parte do que queremos dizer relaciona-se com que os sentidos explicitados na materialidade linguística do discurso jurídico que significam a língua espanhola de maneira positiva (eufórica) vinculam-se a características que são vistas, nesse mesmo discurso, como inerentes a ela: o espanhol é uma língua com "grande riqueza cultural e bibliográfica", "falada na maioria dos países americanos que estão próximos geograficamente ao Brasil” e de "vinculação espiritual” com outros países vizinhos ao Brasil. Já os sentidos aos quais chegamos, por inferência, a partir das análises das condições de produção e da memória do enunciado (cf. COURTINE, 2009, p. 90), significam essa língua de maneira disfórica: uma língua que foi incluída após a exclusão de outra, para completar um número e complementar a carência de recursos culturais "da língua nacional”, submetendo a um questionamento o préconstruído (ao qual também se dá visibilidade) de que poderia ser estudada superficialmente e 
com a "espontaneidade" e "informalidade" de um autodidata.

Considerando, portanto, o conceito de espaço de enunciação de Guimarães (2005) e a série de sentidos com a qual a língua espanhola é colocada em relação, a partir da materialidade linguístico-discursiva dos fragmentos dos documentos jurídicos que analisamos, continuaremos a analisar documentos desse âmbito, a fim de identificar estabilizações e/ou deslocamentos de sentidos que tenham uma incidência significativa no funcionamento da memória sobre a língua espanhola no Brasil e na "disputa incessante" que supõe o fato de ela habitar, justamente, um determinado espaço de enunciação: o da escola.

\section{As LDBS DE 1961 A 1996}

Com relação ao segundo recorte, antecipamos que o mesmo estará marcado por um processo de indeterminação das línguas estrangeiras na materialidade dos documentos jurídicos, processo este que é observado por Rodrigues (2010, p. 94) e que exploraremos a fim de fomentar as análises referentes à questão motriz desta dissertação: os sentidos projetados sobre a língua espanhola no espaço de enunciação escolar.

No que concerne ao referido processo, consideramos pertinente destacar dois momentos, que diferenciaremos a seguir com base na pesquisa de Rodrigues (2010, p. 83-98) e que serão produtivos para nossa análise: o primeiro se refere à promulgação das LDBs de 1961 (Lei N. 4.024/61) e de 1971 (Lei N. 5.692/71). Selecionamos essas duas leis por concordar com a consideração de Rodrigues (2010, p.83-98) de que a textualidade das mesmas representa uma ruptura com relação aos decretos anteriores que, como apresentamos no item 1 deste capítulo, acabaram regulamentando o ensino de línguas estrangeiras na educação brasileira mediante um verdadeiro processo de determinação que contemplava a especificação não apenas dos nomes, mas também, de uma série de aspectos referentes à 
implementação do ensino dessas línguas nas escolas, tais como, o(s) ano(s) em que seriam estudadas, em que caráter (obrigatório ou optativo), quantas aulas deveriam ser oferecidas por semana e, em alguns casos, até mesmo o tempo de duração dessas aulas.

Com respeito à LDB de 1961, essa ruptura é observada, pois essa lei reelaborou o currículo oficial brasileiro sem fazer menção às línguas estrangeiras, nem quanto à inclusão nem quanto à exclusão. Ou seja, em nenhum fragmento da materialidade desse discurso faziase referência a essas línguas. Nesse sentido, é válido reenviar às conclusões de Rodrigues ${ }^{83}$ segundo as quais a textualidade dessa lei operou o que ela designa como um "apagamento" sobre as línguas estrangeiras presentes tanto nos documentos jurídicos quanto no espaço escolar brasileiro até aquele momento. E, a essa interpretação, a autora ${ }^{84}$ acrescenta uma outra: esse gesto de "apagamento" aponta um processo que ela designa de "desoficialização" das línguas estrangeiras como disciplinas por parte das instâncias governamentais que regulamentam os currículos das escolas brasileiras - processo que ao longo da análise desenvolvida por essa pesquisadora vai sendo confirmado. Em outras palavras, o movimento delineado nos decretos que analisamos no primeiro item deste capítulo - considerado por nós como fazendo parte de um processo de "inclusão/exclusão" - e cujo objetivo era determinar, mediante a legislação, quais línguas estrangeiras fariam parte do currículo escolar, foi interrompido e desconstruído de modo que o ensino de toda e qualquer língua estrangeira deixou de ser oficial nas instituições de ensino regulares.

Após o "apagamento" e o processo de "desoficialização” que o mesmo desencadeou, ambos detectados e assim caracterizados por Rodrigues (2010, p. 85-92) na LDB de 1961, consideramos pertinente analisar a LDB seguinte, de 1971, pois esta retoma, em sua materialidade discursiva, a temática do estudo de línguas estrangeiras nas escolas brasileiras, propondo, como veremos no recorte que selecionamos, a possibilidade de que:

\footnotetext{
${ }^{83}$ Ibidem p. 90.

${ }^{84}$ Ibidem.
} 
LDB/71_a $\mathbf{a}^{\mathbf{8 5}}$ : Em qualquer grau, poderão organizar-se classes que reúnam alunos de diferentes séries e de equivalentes níveis de adiantamento, para o ensino de línguas estrangeiras e outras disciplinas, áreas de estudo e atividades em que tal solução se aconselhe. (grifos nossos) ${ }^{86}$

Consoante Rodrigues ${ }^{87}$, o diferencial dessa LDB é que, embora não haja mais o que a mesma considera como um "apagamento", posto que o termo "línguas estrangeiras" volta a aparecer na materialidade discursiva do texto jurídico, há, por outro lado, o que ela interpreta como uma forte "indeterminação". A referida pesquisadora analisa essa "indeterminação" com base na observação de que na textualidade dessa LDB de 1971 não é estabelecido um limite numérico de línguas estrangeiras a serem oferecidas, não é especificado quais línguas deveriam ser essas e nem determinado o tempo de estudo destinado às mesmas, conforme era possível verificar em todos os textos dos documentos jurídicos analisados no item 1 deste capítulo. Consideramos, pois, que o "apagamento" detectado por Rodrigues ${ }^{88}$ na LDB de 1961 marcou o início de um forte processo de "indeterminação" que veio a materializar-se, discursivamente, na textualidade da LDB de 1971 e que, como mostraremos, terá continuidade nas LDBs posteriores.

Outra forma de indeterminação encontrada por Rodrigues (2010, p. 95) na LDB de 1971 refere-se ao papel que as línguas estrangeiras deveriam desempenhar no modelo educacional, segundo a proposta dessa lei. De acordo com a análise da referida pesquisadora, haveria uma "indeterminação" também com relação a esse "papel” sinalizado:

[...] na forma como o sintagma "ensino de línguas estrangeiras" é colocado numa relação de coordenação com uma sequência abrangente que inclui "outras disciplinas, áreas de estudo e atividades", produzindo um efeito de equivalência entre os termos coordenados. Parece-nos interessante o fato de que o primeiro item dessa enumeração - o "ensino de língua estrangeira" - é assumido na textualidade legal como uma disciplina - já que em seguida aparecem "outras disciplinas" -, mas, ao mesmo tempo, aparece

\footnotetext{
${ }^{85}$ Esclarecemos que sempre que citarmos fragmentos referentes às Leis de Diretrizes e Bases da educação brasileira que mobilizaremos neste item, indicaremos o mesmo pela sigla referente à descrição apresentada na ementa dessa lei (Estabelece as diretrizes e bases da educação nacional), portanto, LDB, acompanhada de uma barra para especificar o ano de promulgação da mesma e por letras minúsculas a fim de ordenar os fragmentos.

${ }^{86}$ Disponível em: <www.planalto.gov.br/ccivil_03/Leis/L5692.htm\#art87> Acesso em: 3 fev. 2011.

${ }^{87}$ Ibidem, p. 94

${ }^{88}$ Ibidem, p. 90
} 
identificado a "áreas de estudo" ou ainda "atividades". (RODRIGUES, 2010, p. 95 - grifos nossos)

A partir das observações realizadas nesse fragmento, Rodrigues ${ }^{89}$ identifica como o caráter que as línguas estrangeiras deveriam assumir na escola estava indeterminado, uma vez que oscilava entre "disciplina", "área de estudo" e "atividade".

Esses dois processos detectados pela autora nas referidas LDBs - ou seja, o de “apagamento" na LDB de 1961 e o de "indeterminação", na LDB de 1971 - fizeram com que as línguas estrangeiras perdessem o caráter de obrigatoriedade e se vinculassem ao caráter do que interpretamos funcionar como o efeito de sentidos de uma "sugestão". Retomamos, da sequência LDB/71_a, o fragmento em questão - "poderão organizar-se classes" - para esclarecer que tal inferência se sustenta a partir do verbo "poderão", que indica uma modalidade do possível e não uma modalidade deôntica e que aparece no primeiro fragmento da LDB de 1971 que apresentamos, associado à oscilação, detectada por Rodrigues ${ }^{90}$, do papel que essas línguas deveriam ocupar no modelo educacional (“disciplina”, "área de estudo" e "atividade"). Observamos, portanto, que se deixa a critério das instituições de ensino optar ou não pelo ensino das línguas estrangeiras, uma vez que estas não aparecem, na textualidade jurídica, vinculadas ao conteúdo formativo geral.

Inferimos, portanto, que o processo de "indeterminação" detectado por Rodrigues teria se iniciado com o apagamento das línguas estrangeiras produzido na LDB de 1961 e se materializado no discurso da LDB de 1971. Esse processo, conforme demonstra a autora ${ }^{91}$, tem, ainda, uma continuidade que pode ser percebida a partir da Resolução de N. 58 de 1976, assinada pelo Presidente do Conselho Federal de Educação (CFE), Padre José Vieira Vasconcellos, cujos artigos substituiriam os da LDB de 1971. Tal resolução determinava que:

\footnotetext{
${ }^{89}$ Ibidem.

${ }^{90}$ Ibidem.

${ }^{91}$ Ibidem, p. 97
} 
R/76_a ${ }^{92}$ : O estudo de Língua Estrangeira Moderna passa a fazer parte do núcleo comum, com obrigatoriedade para o ensino de $2^{\circ}$ grau, recomendando-se a sua inclusão nos currículos de $1^{\circ}$ grau onde as condições o indiquem e permitam (Artigo $1^{\circ}$, BRASIL, 1976 apud RODRIGUES ${ }^{93}$ ).

Com respeito a esse fragmento, é válido pontuar duas alterações na materialidade discursiva que, consoante Rodrigues ${ }^{94}$, funcionam como um indício do que ela considera uma “especificação". A primeira seria, conforme observa a própria pesquisadora, a utilização do termo "língua estrangeira" no singular e não mais no plural como na LDB anterior. E, a segunda, ainda conforme a autora, seria o adjetivo moderna associado a esse termo na textualidade jurídica. A partir dessas observações, Rodrigues infere que:

Apesar de parecer designar uma certa classe - qualquer língua falada fora do Brasil naquele momento -, essa especificação, considerando o contexto no qual foi produzida, levava à identificação desse sintagma apenas com algumas línguas que, por um lado, possuíam prestígio internacional enquanto línguas veiculares e, por outro lado, estavam dotadas da mais recente tecnologia que as metodologias de ensino de línguas estrangeiras da época preconizavam como base para o êxito no processo de aprendizagem. Nesse contexto, a primeira determinação que o sintagma "língua estrangeira moderna" produz é a que o vincula a uma língua veicular ocidental; a segunda é a que relaciona essa "língua moderna" com aquelas que, naquela época, já se encontravam suficientemente instrumentalizadas para serem ensinadas dentro de uma certa metodologia. Ambas as determinações língua veicular ocidental e língua instrumentalizada ${ }^{95}$ - concorrem para que o inglês seja identificado como a única língua que cumpre esses requisitos

\footnotetext{
${ }^{92}$ Consideramos válido esclarecer que esta resolução não se trata de uma Lei, como a LDB anterior e as que analisaremos a continuação. Ao mobilizá-la, Rodrigues (2010, p. 97) infere que pelo fato de ter sido emitida e imposta diretamente pelo Conselho Federal de Educação, não havendo todo aquele processo de tramitação em Congresso para um posterior sansão presidencial, esse tipo de documento jurídico se assemelha aos Decretos, os quais analisamos no item anterior. Nesse sentido, representamos a sequência recortada dessa Resolução pela letra $\mathbf{R}$ em maiúscula, seguida por uma barra e a indicação do ano em que foi assinada e uma letra em maiúscula para indicar a ordenação.

${ }^{93}$ Ibidem.

${ }^{94}$ Ibidem., p. 98

${ }^{95}$ No que concerne às inferências desenvolvidas por Rodrigues (Ibidem), gostaríamos de considerar que com relação à adoção quase que homogênea da língua inglesa nas escolas regulares, mesmo sem estar especificada na LDB de 1976 e nem na LDB posterior, não podemos compreendê-la somente pelo fato de esta ser uma língua ocidental veicular e de estar "suficientemente instrumentalizada" como argumenta a autora. É preciso considerar, por um lado, que há outras línguas ocidentais que também apresentam o caráter veicular e uma instrumentalização suficiente (como o espanhol, por exemplo); e, por outro, ressaltar que a interpretação metafórica de língua estrangeira moderna como sinonímia de língua inglesa deve-se também e, principalmente, a questões de política linguística como as que apontamos na Introdução desta dissertação. É válido retomar que essa política regulada por espaços e relações de poder e de conflito de interesses regulados pelo Estado e por diferentes forças sociais vinculam a língua inglesa aos sentidos de globalização (cf. TORQUATO, 2010) e a uma cadeia de pré-construídos como: língua de negócios, língua obrigatória, língua de acesso ao mercado de trabalho, língua franca, língua universal, etc. (cf. SOUSA, p. 13, 2007). Nesse sentido, consideramos pertinente pensar que a primazia da língua inglesa na escola e a sua interpretação de língua estrangeira moderna por excelência é efeito dessa política.
} 
necessários para habitar o espaço escolar, ainda que a legislação não a especifique como tal (RODRIGUES, 2010, p. 98, grifos nossos.).

É válido, considerar, portanto, que, embora a indeterminação continue - mesmo com essa determinação linguística, detectada pela pesquisadora a partir do sintagma "língua estrangeira moderna" e do funcionamento das línguas no real da história que também produziam uma determinação discursiva de qual língua estrangeira deveria ser estudada -, essa nova resolução retoma o caráter de obrigatoriedade do ensino de línguas estrangeiras que havia sido apagado nas LDBs anteriores.

A esse momento marcado por um contínuo processo de "indeterminação" no que se refere às línguas estrangeiras que culminou com a perda de seu caráter de obrigatoriedade e sua consequente associação ao que caracterizamos como uma "sugestão" - por oposição a uma modalidade deontológica -, opomos um segundo momento, que será marcado pela “obrigatoriedade dessas línguas" e que teve seu início na textualidade da resolução de 1976, conforme observamos.

Nesse segundo momento, enfocaremos a promulgação da LDB de 1996 (Lei N. 9.394/96). Nessa nova lei, destacamos três aspectos, com base na análise de Rodrigues (2010, p. 99-104). O primeiro é o de que se retoma o caráter de obrigatoriedade do ensino de línguas estrangeiras para o Ensino Médio ( $2^{\circ}$ grau), conforme já previsto na resolução de 1976, porém ampliando-o, também, para o ensino fundamental ( $\left.1^{\circ} \mathrm{grau}\right)$. O segundo é o de que se mantém a "indeterminação", materializada na textualidade jurídica pela liberdade de escolha, por parte das instituições e das comunidades escolares, com relação à língua estrangeira a ser estudada. E o terceiro, no qual se enfatiza a desvinculação dessas línguas do conteúdo formativo essencial, inserindo-as na parte "diversificada" do currículo escolar, conforme podemos perceber nas sequências dessa LDB que apresentamos baixo:

LDB/96_a:Das Disposições Gerais

Seção I - Art. 26

$\S 5^{\circ} \mathrm{Na}$ parte diversificada do currículo será incluído, obrigatoriamente, a partir da quinta série, o ensino de pelo menos uma língua estrangeira 
moderna, cuja escolha ficará a cargo da comunidade escolar, dentro das possibilidades da instituição ${ }^{96}$. (grifos nossos)

LDB/96_b:Do Ensino Médio

Seção IV - Art. 35 -III - será incluída uma língua estrangeira moderna, como disciplina obrigatória, escolhida pela comunidade escolar, e uma segunda, em caráter optativo, dentro das disponibilidades da instituição. ${ }^{97}$ (grifos nossos)

Com base nessas sequências que recortamos da LDB de 1996, podemos observar que sua textualidade mantém o termo "língua estrangeira", retomado na LDB de 1971, assim como a especificação "moderna" acrescentada pela Resolução N. 58 de 1976. Ante essa observação, apresentaremos algumas considerações em relação ao "campo" do arquivo que mobilizamos e analisamos até o momento - isto é, o dos documentos jurídicos - posto que as mesmas nos orientarão a formular algumas reflexões produtivas a nossa pesquisa. Entendemos que tais documentos estão vinculados a um lugar de enunciação (cf. ZOPPIFONTANA, 2003, p. 199) sustentado pela meta-instituição do Estado, que supõe uma potência enunciativa, se pensarmos na "caixa de ressonância" (cf. LEWKOWICZ, 2003) que este (o Estado) implica. Sendo assim, consideramos que, os discursos dos documentos jurídicos projetam uma potência enunciativa cujo efeito é de autoridade e, até mesmo, de imposição em relação às determinações que estabelecem para regulamentar as diferentes instâncias sociais (educação, saúde, habitação, profissional, etc.). No entanto, ponderamos também, com base em Pêcheux (1969, p.75-76), que todo discurso está associado às condições de produção, que envolvem, por sua vez, relações de força e de sentido.

Ante tais conceitos e reflexões, podemos interpretar aspectos relacionados às práticas de implementação, por parte das escolas, das determinações propostas na LDB de 1996 em relação ao ensino da "língua estrangeira". De nossa perspectiva, consideramos que os dizeres

\footnotetext{
${ }^{96}$ Em relação a esse fragmento, consideramos válido atentar para o fato de que as expressões "comunidade escolar" e "possibilidades da instituição" abrem espaço à indeterminação, uma vez que não se especifica quem se antecipa como fazendo parte, necessariamente, da comunidade escolar, nem quais possibilidades da instituição devem servir de parâmetros para a escolha da língua estrangeira. Assim sendo, essa indeterminação se materializa no real, sobretudo na relação com a interpretação e com as práticas adotadas por cada instituição para implementar as determinações dessa lei

97 Disponível em: <www.planalto.gov.br/ccivil_03/LEIS/19394.htm>. Acesso em: 3 jan. 2011.
} 
referentes às determinações sobre o ensino de uma "língua estrangeira moderna" - os quais, destacamos nas sequências LDB/96_a e LDB/96_b -, são enunciados a partir de um lugar de enunciação sustentado pela meta-instituição do Estado e pela potência enunciativa que a mesma lhe confere, mas não ressoam isoladamente, e sim vinculados às condições de produção. Dessa maneira, entendemos que a "potência enunciativa" da LDB de 1996 de não especificar qual língua estrangeira moderna deve ser ensinada nas escolas brasileiras é submetida a um jogo de relações de força, nas condições de produção dessa lei, que, de nosso ponto de vista, é regulado pelo que Orlandi (1988) define como política linguística. Assim, consideramos que as condições em que se publicou a referida LDB, assim como aquelas que abrangem sua vigência até o momento, projetam sentidos que, segundo as interpretações de Sousa (2007) com base em Revuz ${ }^{98}$, apresentam a língua inglesa como uma variante que consiste em um "código comum" para comunicação internacional e, assim, filiam-na a uma série de pré-construídos - como já dissemos na Introdução desta dissertação - tais como: língua de negócios, língua obrigatória, língua de acesso ao mercado de trabalho, língua franca, língua universal, etc. ${ }^{99}$ Tais sentidos, entrariam, pois, em relações de força com a "indeterminação" da língua estrangeira a ser estudada nas escolas brasileiras, projetada na textualidade da LDB de 1996.

A partir do exposto, concluímos que ao referido sentido de "indeterminação", ainda que projetado a partir da "potência enunciava", a qual, já especificamos e analisamos, entra em confronto com a força do real, que impõe a preponderância da língua inglesa, produzindo o que consideramos como uma forte determinação discursiva (INDURSKY, 1997). Nesse sentido, entendemos que em meio ao processo designado, por Rodrigues (2010), como “desoficialização" das línguas estrangeiras na educação nacional - analisado a partir de

\footnotetext{
${ }^{98}$ A obra na qual Sousa (2007) fundamental suas reflexões é: REUVZ, C. (1998). A língua estrangeira entre o desejo de um outro lugar e o risco do exílio. (Trad. por Silvava Serrani-Infante). In: SIGNORINI, I. (org.) Lingua(gem) e identidade. Campinas: Fapesp/Faep/Mercado de Letras, p. 213-230.

99 Ibidem.
} 
documentos jurídicos e, fundamentalmente, do sentido de "indeterminação" projetado pelos mesmos - o funcionamento das condições de produção contribuiu para configurar um novo contexto para essas línguas no espaço escolar no final da década de 90: a determinação discursiva da língua inglesa e, conforme Sousa (2007, p. 15), o monopólio desta nas escolas, sem que estes fossem discutidos ou analisados "pela comunidade escolar", tal como determinado na textualidade da lei.

Com respeito, especificamente à língua estrangeira que focamos nesta pesquisa, esse contexto causou, segundo Fernández (2000, p. 60-65), "dois sérios problemas": o primeiro foi a escassez de alunos interessados em aprender espanhol, que culminou com a redução do número de instituições que oferecessem o ensino dessa língua e também de profissionais qualificados nessa área; e o segundo foi a falta de materiais didáticos de ensino de espanhol disponíveis no mercado brasileiro. Nós vincularíamos "esses dois sérios problemas" à série de sentidos disfóricos que foi atribuída ao espanhol e que analisamos no item 1 deste capítulo, a saber: o de língua incluída por primeira vez no currículo escolar brasileiro em concomitância com a exclusão de outra língua estrangeira, no caso o alemão; o de ser incluída para completar um número de línguas pré-estabelecido e complementar "a carência de recursos culturais" da língua nacional; e, também, o de língua que deveria deixar de ser associada aos sentidos de “estudo superficial” e à metonímia que este modo de dizer abre.

Nesse contexto imediato é que "acontece" a promulgação da Lei 11.161 , de 05 de agosto de 2005, um documento jurídico que, justamente, vem determinar, em sua materialidade linguística, uma língua específica a ser oferecida de modo obrigatório no espaço escolar brasileiro. Será, pois, este documento que focalizaremos no item seguinte.

\section{A LEI N. 11.161/2005}

Em contraposição a esse cenário que interpretamos como "desfavorável” para a língua 
espanhola no espaço de enunciação escolar brasileiro - e que entendemos estar relacionado, de alguma forma, com o processo de "desoficialização" das línguas estrangeiras na escola, identificado por Rodrigues a partir das LDBs - é sancionada, pelo então Presidente da República, Luiz Inácio Lula da Silva, em 5 de agosto de 2005, a Lei N.11.161, que "dispõe sobre o ensino da língua espanhola" na educação nacional. Essa lei derivou do Projeto de Lei N. 3.987/2000, elaborado pelo deputado Átila Lira em 2000, que tramitou no Congresso Nacional durante cinco anos até receber a aprovação do poder legislativo e, assim, a sanção presidencial.

$\mathrm{O}$ artigo $1^{\circ}$ e o inciso $2^{\circ}$ desse mesmo artigo dispõem, respectivamente que "o ensino da língua espanhola, de oferta obrigatória pela escola e de matrícula facultativa para o aluno, será implantado, gradativamente, nos currículos plenos do ensino médio" e será "facultada a inclusão" dessa língua "nos currículos plenos do ensino fundamental de $5^{\mathrm{a}}$ a $8^{\mathrm{a}}$ séries.".

Para a pesquisa de Rodrigues (2010) é muito produtiva a mobilização que ela faz do conceito de acontecimento discursivo a fim de relacioná-lo com as interpretações que formula sobre a textualidade dessa lei. A pesquisadora ${ }^{100}$ pondera, com base na análise de outros documentos jurídicos relacionados ao ensino de línguas estrangeiras no Brasil desde o período colonial, os quais retomamos nos itens 1 e 2 deste Capítulo, que a Lei N. 11.161/2005 pode ser considerada como um "acontecimento discursivo" "101, tal como o entende Pêcheux ${ }^{102}$.

Ao relacionar tal conceito à materialidade discursiva da Lei N. 11.161/2005, a pesquisadora afirma que essa lei pode ser entendida como um acontecimento discursivo, fundamentalmente, por dois aspectos:

\footnotetext{
${ }^{100}$ Ibidem., p. 14-15.

${ }^{101}$ Para elaborar e sustentar tal formulação, Rodrigues (ibidem) retoma de Pêcheux (1999, p. 52) a definição de acontecimento discursivo como aquele que "vem perturbar a memória", e assim produzir dois efeitos: um seria “a interrupção, podendo desmanchar essa 'regularização' e produzir, retrospectivamente, outra série sob a primeira"; e o outro seria o de "desmascarar o aparecimento de uma nova série que não estava construída enquanto tal". A partir dos efeitos que Pêcheux (1999, p. 52) vincula ao conceito de acontecimento discursivo, a pesquisadora entende que é o segundo deles aquele que se "abre" com a sanção da Lei N. 11.161 de 2005.

102 A obra de Pêcheux citada por Rodrigues (2010, p. 15) corresponde à mesma que apresentamos em nossas Referências Bibliográficas, cuja data de publicação é 1999.
} 
O primeiro é o fato de que, pela primeira vez na história legislativa do país, o Congresso Nacional aprovou e o Presidente da República sancionou uma lei que trata de modo exclusivo da inserção de uma língua estrangeira específica - o espanhol - como disciplina escolar integrada ao currículo do sistema de ensino brasileiro; o segundo se refere ao fato de que a textualidade dessa lei, para chegar a ser aprovada nas condições de produção que a determinaram, precisou se descolar de uma memória constituída e, assim, abrir espaço para o funcionamento de novos sentidos nessa memória (RODRIGUES, 2010, p.111).

No que concerne ao primeiro dos aspectos, lembramos, com base no já exposto neste capítulo, que embora a Exposição de Motivos da Reforma Capanema de 1942 tenha determinado a inclusão do ensino da língua espanhola na grade curricular do nível secundário das escolas, este documento jurídico configura-se como um decreto e, portanto, diferentemente da Lei N. 11.161/2005, não tramitou pelo Congresso Nacional sendo imposto, diretamente, pelo Presidente em exercício na época. E, com respeito ao segundo aspecto, acrescentamos que a "memória constituída" a qual Rodrigues (2010, p. 112) menciona entra em relação com a sanção da primeira LDB, em 1961 e que, como expusemos, desencadeou um processo de "indeterminação" das línguas estrangeiras nos currículos escolares brasileiros, materializado na LDB de 1971 e que teve continuidade, sob modalidades diferentes, nas LDBs seguintes (1976 e 1996). Sendo assim, para determinar o espanhol como a língua de “oferta obrigatória" nas escolas regulares, a textualidade da Lei N. 11.161/2005 precisou “descolar-se", nos termos de Rodrigues ${ }^{103}$, do sentido de "indeterminação", regularizado na memória discursiva do arquivo jurídico.

Feitas tais considerações, a autora ${ }^{104}$ pondera que assim como qualquer outra lei, sua implantação após a sanção está vinculada à interpretação da textualidade legal. No caso específico das leis relacionadas ao âmbito educacional, Rodrigues ${ }^{105}$ esclarece que essa interpretação é realizada por instâncias governamentais ligadas ao Ministério da Educação e

\footnotetext{
${ }^{103}$ Ibid., p. 111-112

${ }^{104}$ Ibidem.

${ }^{105}$ Ibidem.
} 
às Secretarias Estaduais de Educação responsáveis por executar o processo de regulamentação das mesmas, processo este que implica em reorganizar a estrutura escolar. Assim sendo, a pesquisadora destaca a relevância de abordar o trabalho de regulamentação realizado por essas instâncias - nos casos em que este foi, realmente, efetivado ${ }^{106}$ - pois, de sua perspectiva, este trabalho coloca em evidência as "fissuras" que a textualidade legal apresenta e que ela (2010, p. 113) analisa, teoricamente, a partir do conceito de "sítios de significação" o qual entende, com base em Orlandi ${ }^{107}$, como os lugares, na materialidade textual, em que as mesmas se abrem, a partir dos gestos de interpretação. Ou seja, para a pesquisadora, a partir de ambos os conceitos é possível compreender como, em determinados sítios de significação da textualidade legal, abre-se espaço a deslocamentos de sentidos que se materializam nas diferentes interpretações que cada Conselho Estadual de Educação do país produz em relação à Lei N. 11.161/2005.

Para analisar esses sítios de significação, Rodrigues ${ }^{108}$ recorta alguns fragmentos da textualidade da referida lei e analisa como as "fissuras" existentes nos mesmos deram margem para que as determinações da mesma fossem interpretadas e regulamentas de maneiras diferentes pelos Conselhos Estaduais brasileiros. Para organizar sua análise, a autora divide os artigos e parágrafos da referida lei em três blocos e, dentre eles, consideramos válido abordar o segundo bloco, composto pelos artigos $2^{\circ}, 3^{\circ}$ e $4^{\circ}$, por considerar que o mesmo terá uma relação mais direta e produtiva com o estudo que estamos desenvolvendo. A seguir apresentamos os referidos artigos, tais como aparecem na textualidade da Lei N. 11.161/2005:

Art. $2^{\circ}$ A oferta da língua espanhola pelas redes públicas de ensino deverá ser feita no horário regular de aula dos alunos.

Art. $3^{\circ}$ Os sistemas públicos de ensino implantarão Centros de Ensino de Língua Estrangeira, cuja programação incluirá, necessariamente, a oferta de

\footnotetext{
${ }^{106}$ Acrescentamos esta observação, posto que, mesmo que o prazo determinado para a regulamentação da Lei N.11.161/2005 tenha expirado em 5 de agosto de 2010 - conforme especificado na textualidade da mesma: "O processo de implantação deverá estar concluído no prazo de cinco anos, a partir da implantação desta Lei." -, muitas Secretarias Estaduais de Educação ainda não concluíram esse trabalho de regulamentação.

${ }^{107}$ Rodrigues entende "sítios de significação" a partir do conceito de sítio significante de Orlandi (2004, p.14), definido como o "sintoma" de um texto, que se constitui num "bólido de sentidos".

${ }^{108}$ Id. p.288.
} 
língua espanhola.

Art. $4^{\circ}$ A rede privada poderá tornar disponível esta oferta por meio de diferentes estratégias que incluam desde aulas convencionais no horário normal dos alunos até a matrícula em cursos e Centro de Estudos de Língua Moderna. (grifos nossos)

Com relação ao segundo artigo, Rodrigues (2010, p. 112) identifica a "fissura" que se abre a partir do sintagma "horário regular de aula dos alunos". Para a autora, esse fragmento entra em relação de confronto com o artigo $1^{\circ}$ da própria Lei, o qual determina que a oferta do ensino da língua espanhola deve ser "obrigatória" por parte das instituições, porém de "matrícula facultativa" por parte dos alunos. Logo, ao colocar ambos os artigos em relação, abre-se espaço à discussão sobre as formas possíveis para inserir uma disciplina de "matrícula facultativa" por parte dos alunos, no "horário regular de aula" dos mesmos. Nesse sentido, os Estados brasileiros apresentaram interpretações divergentes sobre tais artigos que se materializaram em diferentes formas de regulamentação do ensino dessa língua nas escolas da rede pública. Rodrigues (2010, p.147-149) destaca que alguns Estados entenderam o sintagma "horário regular" como o período em que o aluno está matriculado e outros entenderam esse sintagma de maneira mais abrangente, considerando-o como o horário de funcionamento da instituição de ensino. Naqueles, o ensino da LE foi inserido na grade curricular oficial das instituições e, nestes, o ensino dessa língua foi ofertado no contra-turno ao que o aluno esteja matriculado.

A respeito do $3^{\circ}$ e do $4^{\circ}$ artigos, Rodrigues ${ }^{109}$ destaca o sentido de "disjunção entre a língua estrangeira da escola e a língua estrangeira dos cursos livres”, projetados pelos sintagmas "Centros de Ensino de Língua Estrangeira" e "Centro de Estudo de Língua Moderna". A pesquisadora entende que tais sintagmas funcionam, na textualidade legal, "no sentido de legitimar, tanto na rede pública de ensino quanto na particular, uma prática que se vincula à memória sobre o ensino das línguas estrangeiras em contexto escolar e que se

${ }^{109}$ Ibidem. 
instaurou no discurso jurídico a partir das LDBs". A autora ${ }^{110}$ refere-se ao imaginário de que a escola "não ensina bem" essas línguas e, portanto, estas podem ser concebidas como um conteúdo extracurricular e serem estudadas de modo isolado, sem vínculos com as demais disciplinas que compõem a grade do Ensino Médio, em centros e institutos que se dedicam exclusivamente a esse ramo de atividade. A partir dessas reflexões, Rodrigues (2010, p. 299) considera que ao determinar como "optativa a matrícula" no ensino de língua espanhola (no artigo $1^{\circ}$ ) e ao propor a criação de "Centros de Estudos/de Ensino de Línguas Modernas/Línguas Estrangeiras" (nos artigos $3^{\circ}$ e $4^{\circ}$ ) a Lei N. 11.161/2005 “comprova a aderência absoluta" de sua discursividade à memória do processo de "desoficialização" das línguas estrangeiras nas escolas regulares que se desencadeou e se desenvolveu, segundo a pesquisa da autora, a partir das LDBs.

Ainda considerando os artigos $3^{\circ}$ e $4^{\circ}$, Rodrigues ${ }^{111}$ destaca como inédito nessa lei o fato de que sua textualidade "traz para o interior da legislação educacional" a contradição entre o sistema de ensino público e o privado, visto que prevê possibilidades diferentes para que cada um desses sistemas regulamente o ensino da LE, não apresentando, assim, uma base nacional comum que norteie todas as instituições de ensino.

Com base nos dois últimos aspectos interpretados por Rodrigues ${ }^{112}$ em relação aos sentidos projetados pela textualidade da lei em tela - a saber, a "disjunção" a que é submetida a LE da grade curricular das escolas regulares e as diferenças previstas para sua implantação em instituições públicas e privadas - identificamos que os mesmos se vinculam, em nossa pesquisa, ao efeito de "informalidade" que, como sinalizamos neste capítulo, parece funcionar como um pré-construído que determina a relação do brasileiro com a língua espanhola. Em outras palavras, no que se refere ao discurso jurídico e à potência enunciativa que o mesmo pode ter a partir da caixa de ressonância que o sustenta (a meta-instituição do Estado),

\footnotetext{
${ }^{110}$ Ibidem., p. 150.

${ }^{111}$ Ibidem., p. 149.

112 Ibidem.
} 
identificamos sentidos que reforçam nossa hipótese de que a língua espanhola esteja filiada a um estatuto "não-disciplinar" no espaço escolar. Esclarecemos que a análise desse efeito de “informalidade" será aprofundada ao longo dos capítulos seguintes, nos quais abordaremos alguns elementos paratextuais de instrumentos linguísticos de LE, a fim de observar como o mesmo é projetado em discursos que circulam no espaço escolar, espaço este no qual a LE, ao passar a ser uma disciplina, deveria sustentar uma determinada "formalização".

Consoante às reflexões que mobilizamos a partir do estudo de Rodrigues, consideramos pertinente sinalizar algumas de nossas considerações a respeito da Lei $\mathrm{N}$. 11.161/2005, que ganharão espessura ao serem retomadas ao final desta pesquisa. Concordamos com a perspectiva da referida autora em analisar essa lei como um “acontecimento discursivo”, quando interpretado no domínio do arquivo jurídico brasileiro sobre o ensino de línguas estrangeiras em contexto escolar, como o faz Rodrigues. E, acreditamos que essa interpretação tão produtiva na pesquisa da autora, também o será em nosso estudo, especialmente na segunda parte desta dissertação. À luz da mesma, observaremos, nas análises que realizaremos de elementos paratextuais da coleção didática Español sin fronteras (ESF) e especialmente em sua terceira edição de 2007, como os sentidos projetados na textualidade dessa lei ressoam e funcionam no discurso dessa coleção voltada ao espaço de enunciação escolar.

Mediante a análise realizada de fragmentos de discursos jurídicos relacionados a leis educacionais neste primeiro capítulo, podemos afirmar que alcançamos dois objetivos importantes para nossa pesquisa. De acordo com o primeiro, conseguimos compreender as condições de produção em que as línguas estrangeiras e, especialmente a língua espanhola, foram inseridas no contexto educacional brasileiro, revelando-nos diferentes processos $-\mathrm{o}$ de inclusão e exclusão das mesmas no currículo oficial escolar, e o de apagamento e de indeterminação responsáveis pelo que Rodrigues (2010) designa como "desoficialização" - 
pelos quais essas línguas passaram/deixaram a/de habitar o espaço de enunciação escolar de nosso país. De acordo com o segundo, conseguimos interpretar os sentidos que foram projetados na memória discursiva sobre a língua espanhola a partir de documentos do arquivo jurídico voltados à educação e que, portanto, tiveram um impacto no espaço de enunciação escolar.

Neste ponto, passaremos ao segundo capítulo desta primeira parte de nossa dissertação, no qual abriremos o arquivo relativo aos instrumentos linguísticos de ensinoaprendizagem de espanhol. 


\title{
Capítulo 2
}

\section{O ARQUIVO DOS INSTRUMENTOS LINGUÍSTICOS: A FUNDAÇÃO E A MOBILIZAÇÃ̃ DE SENTIDOS PARA O ENSINO DA LE NO BRASIL.}

\begin{abstract}
"O Discurso Fundador não se apresenta como já definido, mas antes como uma categoria do analista a ser delimitada pelo próprio exercício de análise dos fatos que o constituem, observada sua relevância teórica". (ORLANDI, 1993, p.7)
\end{abstract}

Conforme exposto em nossa Introdução, neste capítulo procedemos à abertura do outro arquivo o qual determinamos relevante para a abordagem da questão de nossa pesquisa: detectar os sentidos atribuídos à LE em domínios discursivos relativos ao espaço escolar e tentar compreender o processo pelo qual esta se filia em tal espaço a um estatuto que caracterizamos como "não-disciplinar".

Sendo assim, neste ponto, abrimos o arquivo dos instrumentos linguísticos (cf. AUROUX, 1992 e DINIZ, 2010) ${ }^{113}$, do qual enfocaremos, especificamente, um manual de ensino, dois livros didáticos, uma coleção didática e, também, uma gramática de LE, todos eles produzidos e publicados no Brasil entre as décadas de 30 e $80^{114}$, período anterior ao que foi publicado o objeto central de nosso estudo, que abordaremos na segunda parte desta dissertação - a coleção didática de LE Español sin Fronteras (ESF). Esclarecemos, ainda, que, diferentemente do Capítulo 1, este arquivo sobre o qual nos debruçamos - o dos instrumentos linguísticos - não está vinculado à organização dada pelas rotinas de uma metainstituição, como ocorre com os documentos jurídicos classificados em decretos, resoluções, projetos de lei, leis, etc., separados de acordo com a área a qual regulamentam (civil, criminal, trabalhista, etc.) e organizados com base nas datas de publicação. Mesmo estando cientes de

\footnotetext{
${ }^{113}$ Desenvolveremos esse conceito ainda nesta parte introdutória do presente capítulo.

${ }^{114}$ É válido mencionar que todos os instrumentos desse período não são mais publicados e nem utilizados no ensino-aprendizagem da LE na atualidade.
} 
que o conceito de arquivo, de acordo com a $\mathrm{AD}$, nunca é dado a priori (GUILHAMOU e MALDIDIER, 2010, p.162) - princípio que nos guiou na forma de ler o arquivo jurídico no capítulo 1 e de submetê-lo a interpretação, inclusive ao colocá-lo em relação com outros arquivos (textos de história, de educação) - consideramos necessário observar que, no caso dos instrumentos linguísticos, não há uma pré-organização institucional que os defina e/ou os classifique. Assim, para selecioná-los, recorremos a pesquisas já realizadas ao ensino de LE no Brasil, fundamentalmente, aos estudos de Celada (2002), de Picanço, (2003) e de Fernández (2000), a fim de identificar instrumentos linguísticos que, conforme as referidas pesquisadoras, tiveram uma presença expressiva no espaço escolar e/ou foram referência para autores de outros livros didáticos no período de tempo que determinamos. Assim, selecionamos cinco objetos, conforme detalhamos a seguir.

Com base no primeiro estudo - o de Celada $^{115}$-, pinçamos dois instrumentos linguísticos, que abordaremos no item 1. e no subitem 2.1, respectivamente: a Gramática de língua espanhola para uso dos brasileiros, de Antenor Nascentes, publicada em $1934^{116}$ e o Manual de Español, de Idel Becker, publicado em $1945^{117}$. A partir do segundo estudo que mencionamos - de Picanço ${ }^{118}$ - selecionamos outros dois instrumentos, ambos mobilizados nos subitens 2.2. e 2.3.: o livro Español básico - submetido no subtítulo à especificação

\footnotetext{
115 Ibidem.

${ }^{116}$ Esclarecemos que, devido à dificuldade de busca de tais materiais, posto que este não é um campo prédefinido, encontramos em bibliotecas apenas a $3^{\text {a }}$ edição desse material, publicada em 1934. Salientamos, porém, que conforme Penha (2002), a $1^{a}$ edição da Gramática de língua espanhola para uso de brasileiros foi publicada em 1920.

${ }^{117}$ Esclarecemos que tanto esta Gramática de Nascentes quanto o Manual de Español de Becker, que será nosso segundo instrumento linguístico, foram analisados e relacionados já por Celada (2002). Portanto, neste trabalho, retomaremos tais instrumentos, a fim de ampliar as análises feitas por essa estudiosa, colocando-os em relação com os outros instrumentos linguísticos de LE que aqui estamos especificando.

118 Picanço (2003, p. 79 - 106) faz uma pesquisa de diversos livros didáticos publicados no Brasil a partir da inclusão do espanhol pela Reforma Capanema de 1942 até o final da década de 60. Conforme seus esclarecimentos, a autora selecionou obras de "grandes mestres do idioma" que foram utilizadas nas escolas durante o período de obrigatoriedade do ensino de LE. Dentre os instrumentos que ela enfoca, não conseguimos ter acesso a todos, devido à antiguidade dos mesmos.
} 
Curso clássico e científico - de José Ramón Calleja Álvarez, de $1953^{119}$ e o Curso práctico de español, de Francisco Frigério, publicado em $1977^{120}$. E, por fim, consoante a pesquisa de Fernández (2000), selecionamos a coleção didática Vamos a Hablar, publicada pela editora Ática, no final da década de $80^{121}$, a qual enfocaremos no subitem 2.4.

Ante a especificação de quais "instrumentos linguísticos" serão enfocados neste capítulo, consideramos relevante esclarecer sob qual perspectiva teórica os compreendemos. Antes, salientamos que não abordaremos as diferenças entre os tipos de instrumentos que selecionamos; isto significa que não enfocaremos aspectos que caracterizam, e em alguns casos diferenciam, uma gramática, um manual, um livro didático ou uma coleção didática, posto que nosso escopo não é analisar o processo de instrumentalização e nem sequer os objetos de modo integral. Nosso objetivo é interpretar os sentidos projetados sobre a LE nos elementos paratextuais desses instrumentos - tal como detalharemos em breve -, nos quais consideramos que essa língua é antecipada com relação a seu processo de ensino/aprendizagem no espaço escolar. Em segundo lugar, esclarecemos que tomamos o conceito de "instrumentos linguísticos" a partir de Auroux (1992, p. 65). Segundo o autor, a gramática e o dicionário são pilares do saber metalinguístico e responsáveis por conduzir a descrição e a instrumentalização de uma língua. Nesse sentido, o objetivo de analisar aspectos de certos instrumentos linguísticos sobre a língua espanhola produzidos no Brasil mostrounos a necessidade de filiar-nos à interpretação que Diniz (2010, p. 130) faz de Auroux ${ }^{122}$ ao, justamente, acrescentar a essas duas tecnologias - o dicionário e a gramática - os livros didáticos. Diniz (2010, p. 130) argumenta que estes também são possíveis instâncias de

\footnotetext{
${ }^{119}$ Consoante os esclarecimentos já apresentados em nota anterior, tivemos acesso apenas à $2^{\mathrm{a}}$ edição desse material, de 1953, sobre a qual trabalhamos. Porém, Picanço (2003, p. 91) menciona, em sua pesquisa, uma edição já de 1946.

${ }^{120}$ A respeito desse instrumento de Frigério, segundo Picanço (ibidem., p.101), o mesmo teria tido sua $1^{\text {a }}$ edição em 1969, no entanto, tivemos acesso apenas à $4^{\mathrm{a}}$ edição, de 1977, em relação à qual formularemos nossa análise.

${ }^{121}$ Com relação a essa coleção também não tivemos acesso à $1^{\mathrm{a}}$ edição. Trabalharemos com a $4^{\mathrm{a}}$ edição, publicada em 1992.

${ }^{122}$ Ibidem.
} 
instrumentalização de uma língua, uma vez que produzem sentidos que afetam a relação que os sujeitos estabelecem com as línguas praticadas em um determinado espaço de enunciação; por esse viés, consideramos ainda algo que afirmamos na Introdução: com base em Souza (1999, p.94), pensamos que os livros didáticos têm sido, tradicionalmente, o principal mediador do ensino promovido pela instituição-escola ${ }^{123}$, espaço este que nos interessa por estar relacionado à nossa questão central - os sentidos projetados sobre a língua espanhola na escola.

Conforme as considerações expostas, faz-se necessário, ainda, retomar o modo como abordaremos a referida série de instrumentos linguísticos: como acabamos de esclarecer, não analisaremos o conteúdo central dos mesmos, isto é, não trabalharemos com as unidades ou capítulos, os textos, imagens, explicações e atividades que os mesmos apresentam. Para a pesquisa que, aqui, desenvolvemos, interessar-nos-ão os textos introdutórios ou que compõem a parte introdutória desses objetos, ou seja, aqueles que antecedem as seções ou unidades e que introduzem as características do instrumento linguístico, como por exemplo: qual seu objetivo, como está organizado, qual o método utilizado, etc. Mediante a análise dessas textualidades, pensamos que será possível observar, também, como a língua espanhola é significada antecipando-se o espaço em que será ensinada - a escola -, ou seja, projetando sobre essa língua sentidos com base em antecipações imaginárias em relação aos elementos desse contexto: tais como, o aluno, o professor, a própria língua espanhola, suas condições de produção, etc. ${ }^{124}$.

\footnotetext{
${ }^{123}$ A respeito da interpretação de Souza (ibidem.), esclarecemos que consideramos o livro didático como o principal mediador, porém não o único, posto que tanto os alunos quanto os professores de LE costumam utilizar outros instrumentos além destes, tais como gramáticas, dicionários, livros de conjugação verbal, etc. No entanto, estes, em geral, acabam ocupando o lugar de materiais complementares ou de apoio. Ao passo que o livro didático se configura, conforme a referida autora (cf. SOUZA, 1999, p.28) e, especificamente no Brasil, por uma série de condições relacionadas ao funcionamento da educação nesse país, como "um elemento constitutivo do processo educacional".

${ }^{124}$ A respeito do elemento que enfocaremos para analisar os instrumentos linguísticos neste capítulo - as introduções e/ou textos que compõem a parte introdutória de tais instrumentos -, consideramos pertinente apresentar alguns esclarecimentos. O primeiro é que já entendemos, a partir deste momento, tais elementos com base no conceito de paratexto e na interpretação que dele faremos a partir de nossa perspectiva teórica, a AD.
} 
Assim, objetivamos continuar identificando os sentidos que se filiaram à memória discursiva sobre a LE no Brasil, porém mais especificamente, a partir de discursividades vinculadas ao espaço de enunciação escolar e que circularam no mesmo. Entendemos que, a partir do funcionamento da memória discursiva, organizou-se um domínio de dizeres e saberes - de acordo com Pêcheux (1988), uma formação discursiva - que, de forma preponderante, determinou os sentidos produzidos em enunciações sobre a LE e, de modo específico, no espaço da escola. Em outras palavras, neste capítulo, nosso escopo é observar como, mediante o processo de ensino-aprendizagem da língua espanhola - que se tornou obrigatória na grade curricular nacional, em 1942 e que foi instrumentalizada a partir de livros didáticos, manuais, coleções, etc. -, os sentidos passam a integrar determinadas séries que são fundadas, retomadas, negadas, deslocadas, enfim, que dão uma continuidade ao funcionamento da memória discursiva sobre a LE, no caso, na inflexão que impõe a antecipação do espaço de enunciação da escola. Para tanto, a fim de observar tal funcionamento, estabeleceremos, ao longo deste capítulo, relações entre os textos introdutórios dos instrumentos linguísticos que selecionamos.

\section{A FUNDAÇÃO DE UMA MEMÓRIA SOBRE A LE}

Dentre os instrumentos linguísticos que selecionamos com base no critério exposto, o primeiro que destacamos é a Gramática de língua espanhola para uso dos brasileiros, cuja primeira edição foi publicada em 1920, por Antenor Nascentes, porém nesta pesquisa trabalharemos com a $3^{\text {a }}$ edição da mesma, do ano de 1934.

Entretanto, para favorecer a leitura deste capítulo não realizamos, aqui, uma abordagem teórica em relação a esse conceito. O mesmo será apresentado no Capítulo 3 - no qual também enfocamos textos de apresentação de nosso objeto central, a coleção ESF - a partir da perspectiva do crítico literário Gérard Genette (2009) e colocado em relações de sentido com noções da teoria da AD. Essa abordagem permitir-nos-á explorar o funcionamento do jogo de imagens (cf. PÊCHEUX, 1969 e ORLANDI, 2007a, p. 41-42) a partir da análise das antecipações que já mencionamos neste capítulo (do aluno, do professor, da própria língua espanhola, dentre outras) e, também, a noção de discurso sobre, definida por Mariani (1998, p. 60 apud RODRIGUES, 2010, P. 1999). 
Como já especificamos, selecionamos instrumentos os quais consideramos terem apresentado alguma relevância e expressividade em relação ao ensino-aprendizagem de LE no Brasil. A esse respeito e no que tange à Gramática de Nascentes, é válido apresentar algumas considerações. Primeiramente, analisando-a em relação ao intradiscurso, isto é, a dizeres que identificamos no próprio instrumento, notamos duas especificações relevantes. Uma já no título, indicando que esse instrumento destina-se a "brasileiros"; e outra, vinculada à autoria, destacando Nascentes como o professor catedrático do Colegio Pedro II. ${ }^{125}$ Mediante tais especificações observadas a partir do eixo do intradiscurso, estabeleceremos, em um segundo momento, relações com o interdiscurso, com base no já exposto no Capítulo 1.

Retomando, pois, as condições de produção que estudamos a respeito da língua espanhola e de seu ensino-aprendizagem no Brasil, acreditamos que essa Gramática tenha circulado no espaço do referido Collegio, que conforme mencionamos no capítulo anterior, serviu, durante muitos anos, de referência para as demais escolas brasileiras. A esse respeito, é válido considerar, também, que no momento de publicação dessa obra (tanto de sua $1^{\text {a }}$ edição, em 1920, quanto de sua $3^{\text {a }}$ edição, em 1934 e com a qual trabalhamos), o espanhol não era uma língua de ensino obrigatório nas escolas brasileiras. Esse aspecto nos leva a pensar que, provavelmente, esse instrumento não tenha tido uma presença expressiva no espaço escolar brasileiro em sua amplitude, ficando mais restrito ao referido Collegio onde Nascentes ministrava aulas de espanhol, língua que era oferecida em caráter optativo. Porém, conforme mostraremos adiante, selecionamos essa Gramática, pois, com base no trabalho realizado por Celada (2002) e em nossas análises, mostraremos que é pertinente pensar que a mesma funcionou como um discurso fundador de sentidos para a instrumentalização da LE no Brasil. Sentidos presentes na Introdução dessa Gramática ressoarão nos textos introdutórios dos

\footnotetext{
${ }^{125}$ É válido destacar que Antenor Nascentes foi um nome reconhecido na área de ensino de língua espanhola não apenas pela publicação desta obra, mas também por ter sido o primeiro professor aprovado em concurso público, com defesa de tese para o Collegio de Pedro II para a cátedra de espanhol, em 1919 quando a disciplina era oferecida apenas em caráter optativo (cf. BARRETO, 2010, p.48).
} 
instrumentos linguísticos que analisaremos na sequência e que, de fato, foram utilizados nas escolas brasileiras para mediar o ensino-aprendizagem da língua espanhola; alguns deles, inclusive, no período de obrigatoriedade da mesma a partir da Reforma Capanema de 1942 até a LDB de 1961, que como analisamos, operou um apagamento das línguas estrangeiras no espaço escolar.

Feitas tais considerações, passaremos à análise do texto introdutório dessa obra ${ }^{126}$. Mediante a leitura da Introdução da Gramática de Nascentes, atentamos para a construção de uma “contradição", já identificada por Celada (2002, p. 62-65) em sua pesquisa. Para explorála, mobilizamos uma sequência ${ }^{127}$ da textualidade dessa Introdução e destacamos um fragmento o qual a referida pesquisadora analisa:

SdN_a: [...] Estando o Brasil cercado de países onde se fala o espanhol e com os quais se acha em relações constantes, de ordem política, comercial, etc., é de grande vantagem para os brasileiros o conhecimento não perfunctório daquela língua [...] (NASCENTES, 1934, p. 4, grifos nossos).

Consoante Celada (2002, p. 63), o fragmento grifado apresenta uma negação, que a autora interpreta, com base em Indursky ${ }^{128}$, como uma negação interna. À luz de conceitos desenvolvidos por esta autora, Celada ${ }^{129}$ opera a transformação dessa negação em uma afirmação - é de grande vantagem para os brasileiros o conhecimento perfunctório daquela língua - e pondera que mediante esse processo o termo "perfunctório" relacionado ao estudo da LE entraria em relação metonímica com a seguinte série de sentidos: "passageiro", "rápido", "ligeiro", "leve”, "superficial”, “sucinto”. A esse respeito, a pesquisadora infere que, considerando o espaço da discursividade em que esse enunciado aparece - na

\footnotetext{
${ }^{126}$ Em todas as análises de instrumentos linguísticos que desenvolveremos neste item, trabalharemos, no corpo de nosso trabalho, com fragmentos de textos que os compõem e, em nota, indicaremos o anexo no qual é possível ter acesso aos mesmos em sua íntegra. Com relação ao texto introdutório da Gramática de língua espanhola para uso dos brasileiros, é possível consultá-lo no anexo C, deste trabalho.

${ }^{127}$ Para organizar a apresentação das sequências que recortamos dos instrumentos linguísticos que analisaremos neste capítulo, utilizaremos a sigla Sd (sequência discursiva), acompanhada das letras iniciais do sobrenome dos respectivos autores, e de letras minúsculas - a, b, c, etc. - para ordená-las.

${ }^{128}$ A obra que Celada (ibidem) mobiliza de Indursky corresponde a que apresentamos em nossas referências bibliográficas e com a data de 1997. Antecipamos, ainda, que abordaremos o conceito de negação, com base na mesma autora, em nosso Capítulo 3.

${ }^{129}$ Ibidem.
} 
textualidade da Introdução dessa Gramática - é válido interpretar sua versão afirmativa como verossímil. Para justificar essa interpretação, Celada (2002) coloca o referido enunciado afirmativo em relações de sentido com fragmentos de outra sequência discursiva dessa Introdução, que apresentamos a seguir:

SdN_b: $O$ espanhol é parecidíssimo com o português, como toda gente sabe. Quem conhece o português com facilidade lê e compreende o espanhol, sentirá, é verdade, algumas deficiências ${ }^{130}$. (NASCENTES, 1934, p. 4, grifos nossos).

Com base na SdN_b, Celada ${ }^{131}$ considera, por um lado, que o fragmento "como toda gente sabe" - que, conforme a especificação indicada no título dessa obra, ela entende poder ser vinculado a imagem de "todo brasileiro" - reforça, confirma e, inclusive, confere um valor de "verdade indiscutível" e de "evidência" ao sentido de que o espanhol e o português são línguas "parecidíssimas". Ainda a respeito do referido fragmento, a estudiosa ${ }^{132}$ acrescenta que o mesmo materializa na textualidade dessa Introdução sentidos "que se apresentam como anteriores, exteriores e independentes ao domínio do pensamento que no fio do discurso está sendo articulado" e que funcionam, nesse fio discursivo, sob o efeito de um pré-construído. Por outro lado, em relação à SdN_b, a estudiosa pondera que desse "valor indiscutível e evidente de semelhança" apresentado sob o efeito de um pré-construído deriva o sentido de facilidade em relação ao estudo da língua espanhola.

Assim sendo, para Celada (2002), tal sequência discursiva corrobora a verossimilhança da afirmação obtida a partir da transformação metodológica do enunciado da SdN_a, isto é, a de que para o brasileiro era de grande vantagem o "conhecimento perfunctório" desse idioma, posto que sendo "semelhante" ao português seria, por conseguinte, "fácil" de ser aprendido por falantes dessa língua, especificamente pelos brasileiros, aos quais essa obra se destina.

\footnotetext{
${ }^{130}$ Em relação à SdN_b, consideramos pertinente apontar que está sendo trabalhada uma relação de competência espontânea, ao menos no plano da compreensão, que fica legitimada por se tratar de uma Gramática escrita por um Catedrático e Filólogo. Ademais, ponderamos que essa relação de competência espontânea nos remete ao fragmento da entrevista de González - o qual abordamos no Capítulo 1 - a respeito das recorrentes práticas de leitura em espanhol, no período em que estava no ginásio e que ainda não tinha estudado essa língua na escola.

131 Ibidem.

132 Ibidem, p.64.
} 
No entanto, se, por um lado, os sentidos de "semelhança" e "facilidade" projetados a partir da SdN_b condizem com a negação “conhecimento não-perfunctório” (da SdN_a) desde que pensada a partir do conceito de negação interna (cf. INDURSKY, 1997) como comportando uma afirmação; por outro lado, considerando apenas o valor de negação Celada (2002, p. 64) considera que se instaura na discursividade dessa Introdução uma contradição. Dito de outra maneira, a pesquisadora entende que negar a "vantagem" do estudo perfunctório da língua espanhola entra em relação de contradição com os sentidos de "semelhança" e de "facilidade" apresentados nessa mesma discursividade.

Para explorar os sentidos dessa contradição, Celada ${ }^{133}$ retoma o que nós designamos como SdN_b, porém com destaque em outro fragmento da mesma e relacionando-a com outra sequência, conforme apresentamos abaixo:

SdN_b: O espanhol é parecidíssimo com o português, como toda gente sabe. Quem conhece o português com facilidade lê e compreende o espanhol, sentirá, é verdade, algumas deficiências. [...] (NASCENTES, 1934, p. 4, grifos nossos).

SdN_c: A extrema semelhança das duas línguas, entretanto, (parece até um paradoxo), é a maior dificuldade que encontramos, pois quando mal pensamos que uma palavra, uma locução, ou uma forma, se encontra em ambas as línguas, defrontamos profunda diferença.

Da perspectiva da pesquisadora, por meio do enunciado destacado em SdN_b - "sentirá, é verdade, algumas deficiências" - vincula-se uma restrição à "semelhança" pressuposta entre o português e o espanhol e, essa restrição é determinada, na SdN_c, como correspondendo à "profunda diferença" existente entres "ambas as línguas". Ante tais reflexões, Celada (2002, p. 67) infere que é a partir da constatação do que ela caracteriza como "restrição" que se determina o objetivo dessa obra, tal como apresentado na sequência seguinte:

SdN_d: Daí a necessidade de precisarmos fixar especialmente o que há de diferente nas duas línguas; foi esse o nosso escopo. (NASCENTES, 1930, p.4 - grifos nossos).

133 Ibidem. 
Com base nas relações e análises que Celada (2002, p. 71) desenvolve, interpreta esse discurso como tendo fundado um modo de interpretar a língua a língua espanhola. Este modo se baseava na proposta de que o estudo dessa língua estrangeira deveria ocorrer a partir da comparação com o português e da identificação de "diferenças" entre ambas as línguas, visto que eram semelhantes.

Em primeiro lugar, para esmiuçar essa interpretação de Celada (2002, p. 71) que caracteriza o dito no texto introdutório da Gramática de Nascentes (e o texto da própria Gramática, visto que em seu estudo a pesquisadora analisou a totalidade desse instrumento) como um discurso fundador, consideramos pertinente recorrer às formulações de Orlandi (2003, p.13). Essa autora entende que o processo de instalação do discurso fundador irrompe pelo fato de que não há ritual sem falhas e ele aproveita fragmentos do ritual já instalado - da ideologia já significante - apoiando-se em "retalhos" dele para instalar o novo. Ante essa compreensão de Orlandi ${ }^{134}$, é possível dar mais espessura teórica à análise que recuperamos de Celada. O que percebemos no discurso introdutório em tela é que nele aproveitam-se os "retalhos" - que seriam os sentidos de "semelhança" entre o espanhol e o português e de "facilidade" no estudo do espanhol por parte de brasileiros - já instalados num imaginário do senso comum. E, a partir destes instala-se o novo, que seria, por um lado, a prática de estudo da língua espanhola ${ }^{135}$ e, por outro, a comparação com a língua portuguesa, porém não com o objetivo de enfocar as semelhanças entre ambas as línguas, mas sim as diferenças entre as mesmas. Segundo Orlandi ${ }^{136}$ essa "eficácia" em produzir o efeito do novo de modo que este se arraigue na memória permanente é o que identifica um discurso como fundador e produz o efeito do familiar, do evidente, do que só pode ser assim. Dito de outra maneira, ao apresentar

\footnotetext{
${ }^{134}$ Ibidem.

${ }^{135}$ Trabalhamos aqui com a prática do estudo da língua espanhola como sendo "o novo" a partir das condições de produção dessa língua já que, conforme apresentado no Capítulo 1, no período de publicação desse instrumento linguístico o espanhol não estava legitimado nas escolas uma vez que nenhum documento jurídico previa essa língua estrangeira como disciplina oficial. Logo, o contato com a mesma deveria ocorrer fora do âmbito escolar (com exceção do Colegio Pedro II o qual já mencionamos) e de uma maneira superficial.

136 Ibidem., p. 14
} 
a língua espanhola como "parecidíssima ao português" e, portanto, "fácil" para quem conhece essa língua, a proposta de ter que estudar o espanhol, a partir da comparação com o português ${ }^{137}$ e com um enfoque especial nas diferenças entre ambas as línguas, surge apoiada em um efeito de evidência, ou seja, de que o estudo do espanhol por falantes de português não poderia dar-se de outra forma.

Um segundo aspecto relevante para sustentar a análise de que esse discurso da Gramática de Nascentes configura-se como fundador é a associação que Orlandi (2003, p.24) propõe entre esse conceito e o conceito de autor, apoiando-se em Foucault ${ }^{138}$. Para a autora ${ }^{139}$, além de se considerar fundadores os discursos "que produzem rupturas localizadas e que são função da atividade discursiva que é em si estrutura e acontecimento, portanto capaz do novo, do deslocamento na filiação discursiva" (e que, conforme mostramos, acontece na Introdução da Gramática de Nascentes), ela prefere guardar o nome de discurso fundador para o que se chama, em Foucault ${ }^{140}$, "instauração de discursividade": quando os autores não são apenas autores de suas obras, mas quando "produzem alguma coisa a mais: a possibilidade e a regra de formação de outros textos". Ante essa nova proposição de Orlandi ${ }^{141}$, também podemos considerar o discurso analisado na introdução da Gramática de Nascentes como fundador, uma vez que - conforme mostraremos, ainda neste capítulo - ele instituiu uma série de sentidos (cf. PÊCHEUX, 1999, p.52) que instalou condições para a formação de outros textos que introduzem instrumentos linguísticos de LE publicados posteriormente.

\footnotetext{
${ }^{137}$ É pertinente considerar que essa abordagem contrastiva para o ensino da LE a estudantes brasileiros, que identificamos ser fundada na Introdução da Gramática de Nascentes - e que como veremos ressoará nas introduções dos demais instrumentos linguísticos que analisaremos neste capítulo -, esteve, segundo González (2005, p.72-75), vinculada à condição periférica de nosso país em relação ao acesso aos modelos teóricos da linguística. Segundo a autora, as pesquisas desenvolvidas no Brasil sobre estudos da linguagem foram quase sempre mediadas pelos centros de difusão de cultura que, em geral, funcionavam como reprodutores de modelos teóricos de segunda mão, os quais reforçavam a prática de ensino contrastivo e não valorizavam a pesquisa e a produção de conhecimento. Assim, nossa país acabou ocupando uma posição que a autora define como de "marginalidade científica".

${ }^{138}$ A obra a partir da qual Orlandi mobiliza o conceito de autor é: FOUCAULT, M. (1983). Qu'est-ce qu'um auteur. In: Littoral, 9, Paris.

${ }^{139}$ Cf. ORLANDI, 2003, p. 24.

${ }^{140}$ Ibidem.

${ }^{141}$ Ibidem.
} 
Em terceiro lugar, ainda explorando a interpretação de "fundador", formulada por Celada (2002), acrescentamos o fato de que o autor não cita, em sua Gramática, nenhum autor ou obra do campo dos estudos sobre o espanhol no Brasil como referência, o que fortalece a conclusão de que os sentidos por ele mobilizados, com relação à facilidade e à semelhança com o português, foram recuperados da instância relacionada ao senso comum; de fato, como aponta Celada ${ }^{142}$, os saberes mobilizados pelo filólogo não conseguiram oferecer a necessária resistência a esses sentidos, que passaram por filosofia espontânea ao campo de produção de conhecimento sobre a língua espanhola, fazendo parte da instância discursiva legitimada por um instrumento linguístico. Com relação ao que observamos a respeito de tomar sentidos do senso comum, apresentamos outra sequência da Introdução do instrumento linguístico que estamos analisando, que ao continuar caracterizando a língua espanhola, formula as seguintes considerações:

SdN_e: [...] Além disso é uma língua familiar a nós por causa da imigração espanhola em nosso país, das companhias dramáticas, de operetas e zarzuelas que anualmente nos visitam, das relações com as repúblicas vizinhas. (NASCENTES, 1934, p.4)

Pensamos, portanto, que esse discurso pode ser considerado não só como fundador mas também como fundacional (cf. CELADA, 2003, p.90), justamente porque ele opera sobre os efeitos de um certo "vazio" de dizer, isto é: ele mesmo se aponta como fundador por não aludir a nenhum outro texto no campo dos estudos sobre a língua espanhola no Brasil. Nesse sentido $^{143}$. Instala-se, assim, no referido campo de estudos, uma "base do dizível" (cf. ORLANDI, 2007a, p. 31) que mobiliza sentidos do senso comum e os legitima na instância dos instrumentos linguísticos e, portanto, do ensino-aprendizagem da língua espanhola no

\footnotetext{
${ }^{142}$ Ibidem, p. 67

${ }^{143}$ É válido considerar que em sua Introdução, Nascentes faz referências a outras obras e autores - a saber ao dicionário e à gramática produzidos pela Academia da Língua Espanhola e ao filólogo espanhol Menéndez Pidal - porém todas essas referências remetem à Espanha, ou seja, não foram produzidas e nem publicadas no Brasil.
} 
Brasil $^{144}$.

Dando continuidade à análise do discurso introdutório da Gramática de Nascentes, podemos observar que são filiados outros sentidos nessa série composta por um jogo de pares (cf. CELADA, 2002, p.71) "semelhança" e "facilidade" / "diferença" e "dificuldade" e caracterizamos como uma dicotomia paradoxal por ser organizada a partir da contradição que se instaura nessa textualidade. Dentre eles, detectamos os seguintes:

a) o de sonoridade e de graciosidade, e o de língua de um grande número de falantes, conforme a sequência que expomos a seguir:

SdN_f: [...] É uma língua sonora, graciosa, falada por quase oitenta milhões de pessoas na Espanha, nas três Américas e em outros pontos do globo [...] (NASCENTES, 1934, p.3, grifos nossos).

b) o de ser uma língua de relações políticas e comerciais, conforme é possível identificar a seguir:

SdN_g: [...] Estando o Brasil cercado de países onde se fala o espanhol e com os quais se acha em relações constantes, de ordem política, comercial, etc. [...] (NASCENTES $^{145}$, grifos nossos).

c) e, por fim, depois de mencionar "de passagem", conforme as palavras do próprio autor, que há outras línguas faladas na Espanha, Nascentes conclui que:

SdN_h: o espanhol, todavia é a língua oficial de todo o reino [...] (NASCENTES, 1934, p.4, grifos nossos).

A respeito da SdN_h, consideramos relevante apresentar a reflexão de como esse significante "reino" funciona na memória discursiva e no imaginário que, no Brasil, filia esse termo à Espanha. Consideramos válido destacar que, nesta $3^{\text {a }}$ edição da obra de Nascentes, de 1934, a Espanha já não era reino desde 1931, ano que fora proclamada sua República. No entanto, o termo "reino" irrompe nessa textualidade e entra em relação com sentidos de

\footnotetext{
${ }^{144}$ A respeito desse papel legitimador que a Introdução da Gramática de Nascentes parece ter assumido em relação aos dizeres e saberes do senso comum sobre a língua espanhola, consideramos válido mencionar outra observação de Celada (2002, p.66). Ao analisar o discurso da lição inaugural de Nascentes na cátedra de Filologia Românica proferido na Universidade do Distrito Federal em 1937, a pesquisador nota que Nascentes também legitima os referidos saberes no âmbito acadêmico.

${ }^{145}$ Ibidem.
} 
império, de poder absoluto, de força, de domínio que são, assim, associados à língua espanhola, e que pareceriam ser importantes para enfatizar a imagem de uma língua que apresentaria uma certa "força" ou "expressividade" no contexto mundial. Nesse sentido, na própria Introdução - isto é, ainda no eixo do intradiscurso - essa imagem é enfatizada quando a LE é apresentada como "falada por muitos e em diferentes pontos do globo" e com "representatividade nas relações políticas-comerciais do Brasil”, posto que esse país está "cercado" de outros onde se fala o espanhol e que, são, nesse caso, os países hispano$\operatorname{americanos}^{146}$.

Ainda no tocante a esse item "c" que apresentamos, recortamos outras duas sequências nas quais aparece referido o processo que disciplinarização dessa língua:

SdN_i: [...] O espanhol é talvez a língua mais disciplinada que haja. Filipe V em 1713 fundou uma academia da língua, a qual, entre outros encargos, recebeu o de elaborar uma gramática e um dicionário [...] (NASCENTES, 1934, p.4, grifos nossos grifos nossos).

SdN_j: [...] Em matéria de ortografia, prosódia, morfologia, purismos de linguagem, vernaculidade, a autoridade soberana na Academia é obedecida sem discrepância; por isso a citamos sempre que queremos afastar contestações.

Uma lei de 9. de Setembro de 1857 declarou a gramática da Academia $o$ texto único e obrigatória das escolas de ensino público. [...] (NASCENTES $^{147}$, grifos nossos).

De nossa perspectiva, interpretamos que o destaque dado nesse discurso ao processo que “disciplinou” a LE está vinculado ao que caracterizamos como uma espécie de "apologia" à academia dessa língua fundada na Espanha e no período em que a mesma era um reino. Essa interpretação entra em relação com o que analisamos a respeito dos sentidos projetados pelo termo "reino" na SdN_h; ou seja que, no discurso dessa Introdução, a LE e, especificamente, os aspectos que a destacam no mundo enquanto uma língua estrangeira são filiados,

\footnotetext{
${ }^{146}$ Entendemos que os sentidos de força e de poder absoluto vinculados ao termo "reino" se estendem também, à língua desse "reino" - o espanhol - e, inclusive, poderiam se estender às terras por ele colonizadas que eram muitas e em diferentes partes do "globo". No caso das sequências que mobilizamos entrariam, especificamente, as regiões colonizadas que cercam um outro país sobre o qual "teriam representatividade nas relações políticascomerciais". Ou seja, a "força" tanto da língua espanhola quanto dos demais países onde a mesma era oficial aparece relacionada no intradiscurso à imagem da Espanha - por ser a língua falada nesse país ou por ter sido colonizado por ele.

${ }^{147}$ Ibidem.
} 
fundamentalmente, à Espanha.

Perante todos esses sentidos incorporados à dicotomia paradoxal, que já especificamos - a saber: "semelhança" e "facilidade' / "diferença" e "dificuldade" -, e que entendemos como fundadora em relação à maneira de interpretar o ensino da língua espanhola no Brasil, a partir de seu contraste com o português, podemos perceber como, na Introdução desse instrumento linguístico, são mobilizados outros dizeres que nos permitem compreender o funcionamento da memória discursiva sobre a língua espanhola e, especificamente, sobre sua instrumentalização no espaço de enunciação brasileiro. Assim sendo, na análise de outros instrumentos linguísticos, procuraremos mostrar como os sentidos mobilizados e legitimados na Introdução da Gramática de Nascentes - em parte, a partir da instância do senso comum, conforme analisamos - vão ser retomados ou submetidos a deslocamentos no funcionamento da memória discursiva sobre o ensino do espanhol.

\section{A MEMÓRIA SOBRe A LE E SUA INFLEX̃̃o NO PROCESSO DE ENSINO- APRENDIZAGEM.}

\subsection{O Manual de Español de Becker}

Dando continuidade à análise dos instrumentos linguísticos, o segundo que pinçamos é o Manual de Español, de Idel Becker ${ }^{148}$, publicado em 1945 e que apresentou um grande destaque para a prática do ensino dessa língua no Brasil a partir da década de $40^{149}$. Segundo

\footnotetext{
${ }^{148}$ Acrescentamos, ainda com base em Picanço (ibidem), que Idel Becker era professor catedrático de Espanhol e Literatura Espanhola da Faculdade de Filosofia da Universidade Mackenzie de São Paulo.

${ }^{149}$ Consideramos pertinente citar um trecho da entrevista com a profa. González em que, ao responder sobre como eram as aulas de espanhol na época em que estudou essa língua na escola, ela faz referência ao Manual de Becker:

SdG_d: [...] Nós estudávamos com o livro do Idel Becker e durante um ano. E, nesse ano, nós seguimos, eu diria, bem à risca, o livro do Idel Becker. Eu tive duas professoras. A primeira se afastou e veio uma outra professora. Do nome da primeira eu me lembro bem: era Berta. Mas, do nome da segunda eu não me lembro, pois foi uma coisa muito
} 
as pesquisas de Picanço (2003, p. 93), em 1958 esse material já se encontrava na sua 31 a edição, aspecto que corrobora o fato de que o mesmo tenha sido amplamente utilizado tanto como mediador da prática do professor de LE quanto como material de apoio, chegando a ser usado, inclusive, na formação universitária.

Passando a abordar sua parte introdutória: este Manual não apresenta um texto de introdução, assim como o da Gramática de Nascentes e os textos dos demais instrumentos que abordaremos. No caso, além do sumário, encontramos dois textos que antecedem as unidades desenvolvidas para mediar o ensino de diferentes aspectos da língua espanhola. $\mathrm{O}$ primeiro deles é apresentado sob o título Difusión de la lengua española. E o segundo é um ensaio do escritor e pensador uruguaio José Enrique Rodó, titulado América ${ }^{150}$.

No primeiro desses textos, Difusión de la lengua española (BECKER, 1970, p.12), a língua espanhola é colocada em relação com o número de seus falantes em outros países do mundo. Retomando a análise que desenvolvemos sobre a Introdução da Gramática de Nascentes, percebemos que essa referência à quantidade de falantes é uma ressonância de sentidos já filiados à LE no funcionamento de uma discursividade. No entanto, ao observar a materialidade a partir da qual esses sentidos são apresentados no Manual de Becker, poderemos notar algumas especificidades. Para tanto, apresentamos, a seguir, a transcrição do referido texto, tal como o mesmo é apresentado no instrumento linguístico em tela:

SdIB_a:

\section{DIFUSIÓN DE LA LENGUA ESPAÑOLA ${ }^{151}$}

rápida. A primeira delas era mais estruturada, ela seguia o livro à risca e a segunda era mais jovem, então ela trazia muita música. [...] (linhas 45-50 - grifos nossos)

${ }^{150} \mathrm{O}$ texto corresponde ao ensaio lido no Congresso do Centenário do Chile, em 17 de setembro de 1910. Essa referência não é citada no texto apresentado no Manual de Becker. Acrescentamos ainda que esse ensaio foi publicado na obra El mirador próspero, de José Enrique Rodó, publicada em 1913. Obtivemos ambas as referências na obra: Aínsa, Fernando (1937) Del canon a la periferia: encuentros y transgresiones en la literatura uruguaya. Alicante: Biblioteca Virtual Miguel de Cervantes, 2003. Disponível em < http://www.cervantesvirtual.com/obra-visor/del-canon-a-la-periferia-encuentros-y-transgresiones-en-laliteratura-uruguaya--0/html/ffc859fa-82b1-11df-acc7-002185ce6064_32.html> Acesso em: 28 abr.2012.

${ }^{151}$ Difusión de la lengua española, texto que compõe a parte introdutória do Manual de Español de Idel Becker. 


\section{EUROPA:}

España peninsular (con las Baleares y las Canarias) y los judíos sefardíes

34.000 .000

ASIA:

Judíos sedardíes (Turquia, Siria, Líbano e Israel)

500.000

ÁFRICA:

Plazas de soberania, províncias africanas y judíos sefardíes

400.000

AMÉRICA DEL NORTE:

Estados Unidos (Nueva York, Arizona, Nuevo Méjico, Texas, California)

10.000 .000

ANTILLAS:

Cuba, Rep. Dominicana y Puerto Rico

14.600 .000

AMÉRICA CENTRAL:

Guatemala, El Salvador, Honduras, Nicaragua, Costa Rica y Panamá

000

15.000 .

AMÉRICA DEL SUR:

Colombia, Venezuela, Ecuador, Perú, Bolivia, Chile Paraguay, Uruguay y

Argentina $\quad 93.000 .000$

OCEANÍA:

Filipinas

Individuos de habla española que habitan en países de otras lenguas (distintos de

los ya citados)

00

1.000 .0

Total de los que hablan español

214.400 .000

Com base nessa materialidade, podemos considerar que esse texto se assemelha a uma tabela ou planilha estatística, que quantifica dados e os soma. Nesse sentido, notamos como o vínculo entre a língua espanhola e o número de seus falantes bem como dos países onde ela é falada reaparece nessa obra, mas de maneira detalhada. Na introdução da Gramática de Nascentes encontramos apenas a referência à quantidade geral e aproximada de falantes "quase oitenta milhões de pessoas" - e a indicação específica a apenas um país e três subcontinentes - "na Espanha, nas três Américas e em outros pontos do globo". Já no Manual de Becker, há a explicitação minuciosa da quantidade de falantes por continentes e por 
subcontinentes bem como a especificação dos países e/ou regiões onde se fala a LE em cada uma dessas partes do planeta.

Interpretamos a materialidade mediante a qual essa textualidade é apresentada - isto é, o grau de especificação que nela aparece por meio de uma tabela - associada ao sentido que a mesma projeta - a quantidade de falantes de LE no mundo - como um gesto na direção de filiar essa língua ao imaginário de uma língua veicular, isto é, "urbana, estatal ou mesmo mundial, que está em toda parte" (cf. GOBARD; DELEUZE e GUATARI apud CELADA, 2002, p. $27^{152}$ ). Imaginário, este, que chegaria ao âmbito escolar mediante o uso desse Manual para o ensino da LE.

É preciso observar, ainda, que nos textos que compõem a parte introdutória da obra de Becker, não há apenas sentidos que possamos colocar em relação com os que identificamos na Introdução da Gramática de Nascentes, mas, também, com aqueles interpretados no discurso dos documentos jurídicos, quando os trabalhamos a respeito de suas condições de produção, na análise realizada no Capítulo 1. Nesse sentido, é válido mencionar que o período de publicação desse Manual foi concomitante ao governo Vargas que, conforme dissemos a partir do estudo de Souza (2005, p. 131-135), apresentava um discurso baseado numa "política de infusão" cujo objetivo era "forçar, nas pessoas, a assimilação de um "espírito de brasilidade"”. Isto nos permite passar ao outro texto que compõe a parte introdutória do Manual de Becker, titulado América e de autoria do escritor e pensador uruguaio, José Henrique Rodó:

SdIB_b:

AMÉRICA

Yo creí siempre que en la América nuestra no era posible hablar de muchas patrias, sino de una patria grande y única; yo creí siempre que si es alta la idea de la patria, expresión de todo lo que hay de más hondo en la sensibilidad del hombre: amor de la tierra, poesía del recuerdo, arrombamientos de gloria, esperanzas de inmortalidad, en América más que en ninguna otra parte, cabe sin desnaturalizar esa idea, magnificarla,

\footnotetext{
${ }^{152}$ As obras que Celada (ibidem) mobiliza dos referidos autores já foram detalhadas em nota de rodapé na Introdução desta dissertação.
} 
dilatarla; depurarla de lo que tiene de estrecho y negativo, y sublimarla por la propia virtud de lo que encierra de afirmativo y fecundo: cabe levantar sobre la patria nacional, la Patria americana, y acelerar el día en que los niños de hoy, los hombres del futuro, preguntados cuál es el nombre de su patria, no contesten con el nombre de Brasil, ni con el nombre de Chile, ni con el nombre de Méjico, porque contesten con el nombre de América.

Toda política internacional americana que no se oriente en dirección a ese porvenir y no se ajuste a la preparación de esa armonía, será una política vana y descarriada.

José Henrique Rodó

(uruguayo)

(BECKER, 1970, p. 9 - grifos nossos).

A partir da leitura desse texto podemos identificar o sentido de valorização de um sentimento pátrio. No entanto, podemos inferir que esse sentimento não entra em uma relação de continuidade com aquele propagado pela "política de infusão" na era Vargas, uma vez que propõe a passagem de um imaginário de pátria nacional ao imaginário de "La Patria Americana”, conforme é possível notar no fragmento que destacamos. Estas considerações nos levam a realizar um parêntese, pois se referem à relação do Brasil com os países da América, inclusive, retomando um fragmento da Gramática de Nascentes que consideramos que ressoa nesse texto da introdução de Becker. Referimo-nos ao fragmento no qual se fazia uma alusão ao Brasil como “cercado de países onde se fala o espanhol” (cf. SdN_g) .

O termo "cercado" nos facilita a passagem a nosso parêntese, pois nos remete ao sentido de isolamento e leva-nos a mobilizar o mito Ilha-Brasil, trabalhado por Rodrigues (2010, p. 276-283). De acordo com a pesquisa desenvolvida pela autora esse imaginário do Brasil como uma ilha, isolado no continente sul-americano baseia-se, de acordo com Donnard ${ }^{153}$ (2009), na mitologia celta. De acordo com essa mitologia, já no século XIII, havia inúmeras lendas relativas ao que se denominava "Ilha-Brasil" que teriam entrado em relação, conforme pesquisas feitas pelos historiadores ${ }^{154}$ Cortesão (1956) e Magnoli (1997), com as

\footnotetext{
${ }^{153}$ A obra que Rodrigues (2010) cita da referida autora é: DONNARD, A. (2009). O Outro Mundo dos celtas atlânticos e a mítica Brasil, ilha dos afortunados: primeiras abordagens. In: Nuntius antiquus. $\mathrm{N}^{\circ} 3$. Belo Horizonte: FALE/UFMG, pp. 14-28. Disponível em: <http://www.letras.ufmg.br/neam/nuntius/edicoes3.html> Acesso em: 15 jan.2010.

${ }^{154} \mathrm{Em}$ relação aos dois historiadores citados por Rodrigues, suas obras são, respectivamente: CORTESÃO, J. (1956). Alexandre de Gusmão e o Tratado de Madri. Tomos I e II. São Paulo: Imprensa Oficial/Fundação Alexandre de Gusmão, 2006. e MAGNOLI, D. (1997) O corpo da pátria: imaginação geográfica e política externa no Brasil (1808-1912). São Paulo: Ed. da UNESP/Moderna.
} 
representações do território colonizado por Portugal, nos mapas dos séculos XVI e XVII, como estando delimitado por fronteiras naturais, o delta amazônico e o estuário platino, e excedendo, assim, os limites impostos pelo Tratado de Tordesilhas. Esse fato foi o que ajudou a resolver os litígios sobre os territórios coloniais de Portugal e Espanha na América, por meio do Tratado de Madri ${ }^{155}$. Também conforme um desses historiadores, Cortesão ${ }^{156}$, esse imaginário teria sido sustentado pelos indígenas que se espalharam pelo território brasileiro seguindo o curso dos rios que circundavam essa "ilha" - já humana, por "estar habitada" - e que funcionaria, conforme o referido historiador, inclusive como uma como uma "ilha cultural", pois, ao ocuparem o território seguindo as margens pluviais, os índios tupi-guaranis iniciaram um processo de difusão de sua cultura e de sua língua que já se configurava como língua-geral. $\mathrm{Na}$ atualidade, segundo Rodrigues ${ }^{157}$, é possível falar da imagem do Brasil como uma "ilha" de língua portuguesa no subcontinente americano hispanofalante, imagem esta recorrente em diversas discursividades e, inclusive, em instâncias do senso comum, quando se trata de definir os espaços ocupados pelo espanhol e pelo português na América do Sul. Segundo a autora, pelo fato de que a imagem do "Brasil-ilha" foi reforçada também em momentos dos séculos XIX e XX, em discursividades nas quais são destacados a descontinuidade e o isolamento do Brasil em relação aos países sul-americanos, é possível detectar no século XXI o funcionamento de "um pré-construído a partir do qual o Brasil aparece como 'líder natural' e continua sendo uma 'ilha' na América do Sul” (cf. RODRIGUES $^{158}$ ). Aparecem aí os sentidos de "exclusividade" e de predestinação que as fronteiras "traçadas naturalmente" (pela água) teriam dado a esse país.

Aliás, a partir dessas reflexões, também podemos associar "cercado" - termo que estamos retomando da textualidade da Introdução da Gramática de Nascentes - a "estar em

\footnotetext{
${ }^{155}$ Cf. CORTESÃO (1956); MAGNOLI (1997) apud RODRIGUES, 2010, p. 276-283.

${ }^{156}$ Ibidem.

157 Ibidem.

158 Ibidem, p. 304.
} 
um cerco", o que não nos distancia dos sentidos do mito Ilha-Brasil (e das ressignificações que este foi sofrendo ao longo da história), pois uma ilha, delimitada por fronteiras de água, mostra-se como um alvo de possíveis ameaças - neste caso, específico, no campo das línguas.

No entanto, vinculando todas essas associações ao ensaio América, de Rodó, apresentado na parte introdutória do Manual de Becker, notamos que os dizeres desse texto entram em contradição com os sentidos projetados pelo termo "cercado" na Introdução da Gramática de Nascentes, tal como interpretamos à luz do imaginário de Ilha-Brasil. O que interpretamos é que no referido ensaio de Rodó, projetam-se os sentidos de: integração, união, harmonia, dilatação da pátria nacional e, portanto, de superação das fronteiras constitutivas da Ilha-Brasil. Tais sentidos podem ser, de nossa perspectiva, associados a fragmentos dos documentos jurídicos, analisados no Capítulo 1, especificamente da Exposição de Motivos da Reforma Capanema, de 1942.

Conforme mostramos, essa Exposição justificava a inserção da língua espanhola na grade curricular das escolas como uma forma de estimular e promover "nossa maior e mais íntima vinculação espiritual com as nações irmãs do Continente" (INEP, 1952, p.26 apud CAMPOS, 2006). Assim sendo, pensamos que os sentidos do texto que compõe a Introdução do Manual de Becker (a citação de Rodó) representa um deslocamento que acompanha o gesto observado no referido documento jurídico. Esse deslocamento materializa-se, tanto nesse instrumento linguístico quanto na Exposição da Reforma Capanema, a partir de dizeres que projetam sentidos cuja direção é a de filiar a língua espanhola aos países hispanofalantes da América e não apenas (ou não de um modo tão forte e exclusivo) à Espanha, conforme observamos nas sequências da Introdução da Gramática de Nascentes (SdN_h, SdN_i e $\left.\mathrm{SdN}_{-} \mathrm{j}\right)$.

Ainda a respeito desse ensaio de Rodó, podemos pensar que o gesto que acabamos de interpretar entra em relação com a exclusão do alemão da grade curricular escolar e a inclusão 
do espanhol para completar o número de línguas estrangeiras determinado para ser ensinado nas escolas brasileiras naquele período. De nossa perspectiva e com base nas condições de produção, tanto a exclusão quanto a inclusão das referidas línguas sinalizaram um deslocamento do eixo de sentidos que remetiam à Europa (marcada pela política de regimes nazifascistas) para o eixo de sentidos que se vinculavam à América.

A partir da análise de determinados aspectos enfocados a partir dos dois textos que compõem a parte introdutória do Manual de Becker, pudemos observar o funcionamento da memória discursiva sobre a LE, a partir da qual são retomados dizeres e/ou sentidos já projetados em outras textualidades. Notamos também como alguns desses dizeres e/ou sentidos, embora retomados, são redirecionados. No caso da relação com o número de falantes da LE no mundo, percebemos, a partir da SdIB_a do Manual de Becker, uma orientação em direção a projetar sentidos que filiassem a LE, de maneira mais forte do que a que identificamos na Introdução de Nascentes, ao imaginário de uma língua veicular. Já a respeito dos dizeres relacionados a uma proximidade com os países hispanofalantes da América, os quais analisamos com base na SdIB_b, observamos, por um lado, um certo “deslocamento" em relação aos sentidos que tais dizeres projetavam na Introdução de Nascentes; e, por outro, uma continuidade em relação aos sentidos que os mesmos projetavam na Exposição de Motivos da Reforma Capanema e que estavam relacionados às condições de produção em que esse Manual foi publicado. Essa análise contribui para que observemos como a memória discursiva sobre a LE no Brasil está sendo submetida a determinadas inflexões a partir do jogo de antecipações que lhe exige o processo de ensino-aprendizagem dessa língua.

Assim, passaremos ao próximo instrumento linguístico. 


\subsection{O Español Básico de Álvarez Calleja}

Prosseguindo com a análise de instrumentos linguísticos de ensino de espanhol para brasileiros, pinçamos, para compor o arquivo que estamos abrindo, o livro Español básico, de José Ramón Calleja Álvarez, cuja $2^{\mathrm{a}}$ edição com a qual trabalharemos foi publicada em $1953^{159}$.

Esse instrumento mostrou-se relevante por materializar, já a partir de seu título, o lugar do espanhol na grade curricular das escolas a partir da Reforma Capanema, de 1942. A esse respeito, esclarecemos que o título Español Básico aparece vinculado à especificação Cursos clássico e científico, o que, de nossa perspectiva, representa um gesto de explicitar a inclusão do ensino da LE no primeiro ano das duas modalidades - Clássico ou Científico - nas quais estava dividido o segundo ciclo do nível secundário ${ }^{160}$, cuja duração total era de três anos e correspondia ao Ensino Médio da atualidade.

Em relação à introdução, elemento a partir do qual estamos enfocando os instrumentos linguísticos neste Capítulo, observamos que o Español básico de Álvarez Calleja, não apresenta um texto tal como o da Gramática de Nascentes, isto é, escrita em prosa e apresentando a língua espanhola - objeto a ser enfocado no instrumento linguísticos - aos estudantes. O único texto que antecede o início das lições didáticas no livro Español básico além do índice - é um Programa de ensino da LE para os cursos clássico e científico ${ }^{161}$, que está dividido em três partes, a saber: I - leitura, II - gramática e III - exercícios. Portanto, nossa análise se pautará na textualidade desse Programa, que é a que introduz esse

\footnotetext{
${ }^{159}$ Retomamos, que nos estudos de Picanço (2003, p. 91) ela analisa a edição de 1946, que antecipamos ter sido a primeira, posto que esta com a qual trabalhamos é a segunda.

${ }_{160}$ Recordamos que a Reforma Capanema de 1942, conforme apresentamos no Capítulo 1, reorganizou a educação nacional, dividindo-a em dois níveis: o Primário, que correspondia às séries iniciais de estudo das crianças entre 7 e 11 anos; e o Secundário, organizado em dois ciclos, o ginasial - que seguia ao Primário e tinha quatro anos de duração (dos 12 aos 15 anos) - e o segundo ciclo designado, de acordo com as preferências acadêmicas dos estudantes, como clássico ou científico e tinha três anos de duração (cf. RODRIGUES, 2010, p. 71).

${ }^{161}$ O programa do curso Español básico (Cursos clássico e científico), de Calleja Álvarez está disponível no anexo $\mathrm{D}$, deste trabalho.
} 
instrumento linguístico. Para tanto, recortamos uma sequência que apresentamos a seguir:
SdCA_a:
II - Gramática

Merecerão especial atenção, porque causa de êrros freqüentes: o valor do $\underline{h}$; a pronúncia do $j$; a emissão do $e, o$, e, $l$, finais; o artigo neutro; o artigo masculino usado, por eufonia, diante de substantivos femininos; o gênero ambíguo; os plurais em ces, os adjetivos que se apocopam; os verbos irregulares de $1^{\mathrm{a}}$ e $2^{\mathrm{a}}$ classe; o verbo de usted; o acento diacrítico. Serão objetos de especial estudo os heteroprosódicos, heterosemânticos, heterogenéricos, heterográficos e biléxicos com relação ao português ${ }^{162}$ (sic) (CALLEJA ÁLVAREZ, 1953, p.8, grifos nossos).

Notamos nesta sequência uma ressonância do modo de interpretar o ensino da língua espanhola no Brasil, que como analisamos no item 1 deste Capítulo, teria sido fundada a partir dos sentidos projetados na Introdução da Gramática de Nascentes. Esse modo estava baseado no ensino do espanhol pelo contraste com o português, que neste Programa do Español básico de Álvarez Calleja aparece materializado nos vários termos compostos pelos prefixos "hetero-" e "bi" - a saber: "heteroprosódicos, heterosemânticos, heterogenéricos, heterográficos e biléxicos" - vinculados ao fragmento "com relação ao português". Essas observações nos permitem entender que o Programa desse livro antecipa a imagem - já presente na Introdução da Gramática de Nascentes - de que a "organização" da língua (cf. ORLANDI, 2007b, p.45) se baseava numa divisão e classificação da mesma que, ao elencar de maneira exaustiva os níveis de contraste que poderiam ser estabelecidos entre o espanhol e o português, retomava e reforçava o gesto fundado na Gramática de Nascentes. Gesto este que, segundo Celada (2002, p. 57) - quem analisou esse instrumento de modo integral e que, inclusive, considerou outros estudos do próprio autor Nascentes ${ }^{163}$ - operava sob um efeito de coisificação $^{164}$ (cf. CELADA, 2002, p.57) em relação a ambas as línguas: o português e o

\footnotetext{
${ }^{162}$ Os termos em itálico correspondem aos grifos do próprio autor e os em negrito aos nossos grifos.

${ }^{163}$ Em relação à análise que Celada $(2002$, p.73) realiza com base também em outras obras de Nascentes, consideramos válido expor a conclusão da autora a respeito do gesto fundador desse filólogo em interpretar o ensino da LE por meio da comparação com o português. Segundo Celada (ibidem.) esse gesto está vinculado a uma metonímia mediante a qual Nascentes identifica tanto o espanhol quanto o português com a norma e com a linguagem literária de ambas as línguas e desconsidera, assim, as diferenças entre as que eram faladas nas respectivas metrópoles - Espanha e Portugal - e as faladas nos países da América.

${ }^{164}$ Esclarecemos que Celada (ibidem), para referir-se a esse contraste termo a termo entre o português e o espanhol, fundado na Gramática e em outras obras que ela analisa de Nascentes, mobiliza a metáfora
} 
espanhol.

Dando prosseguimento à interpretação dos sentidos projetados sobre a LE a partir do Programa do Español básico de Álvarez Calleja, destacamos uma segunda sequência que, corresponde, a uma especificação dada a esse Programa e que, inclusive, coincide com a do título:

\section{SdCA_b: PROGRAMA CURSOS CLÁSSICO E CIENTÍFICOS ${ }^{165}$ (sic) (CALLEJA ÁLVAREZ, 1953, p.7).}

De nossa perspectiva, o termo "cursos", vinculado a um instrumento linguístico desenvolvido para mediar o ensino-aprendizagem de uma determinada área de conhecimento - em nosso caso à LE - projeta sentidos que nos remetem ao imaginário de continuidade, de aprofundamento e de sequência em relação ao estudo e à aprendizagem dessa língua. Essa reflexão nos levou a colocá-lo em relações de sentido com o título desse instrumento Español básico - que, como já dissemos, também está especificado pelo subtítulo "cursos clássico e científicos". Por meio dessa relação, identificamos uma contradição entre os sentidos projetados pelo termo "cursos" e os projetados pelo adjetivo básico que, no título, caracteriza o Español. De nosso ponto de vista, esse adjetivo nos remete a pensar em um estudo "inicial" - e aqui ressoa o significante da negação de Nascentes: "perfunctório" ${ }^{166}$ que não entra em metonímia com os sentidos de continuidade, aprofundamento e sequência que o sintagma "cursos" projeta. Esta interpretação nos permite, inclusive, dizer que o préconstruído que, aí, funcionava era o de que um nível inicial de espanhol bastava para completar o estudo de todo esse ciclo designado como cursos clássicos e científicos. Além

\footnotetext{
"coisificação", utilizada por Lemos, a partir de Bakhtin, para caracterizar o gesto epistemológico das ciências exatas ou naturais, com base na exposição que dela faz Lemos. A obra que a referida autora cita de Lemos é: LEMOS, C T. G. de. (1994). A Função e o Destino da Palavra Alheia: três momentos da reflexão de Bakhtin. In: Barros, D.L.P. y Fiorin, J.L. (orgs.) Dialogismo, Polifonia, Intertextualidade. São Paulo: Edusp, p. 37-43.

${ }^{165}$ Esclarecemos que a transcrevemos com letras maiúsculas, tal como aparece na textualidade do Programa e que sinaliza uma relação com esse título, também escrito com letras maiúsculas.

166 Podemos reconhecer nessa contradição que identificamos a ressonância, também, da advertência da Exposição de Motivos da Reforma Capanema de que, em relação ao espanhol era importante "estudá-lo, não pela rama e autodidaticamente, mas de modo metódico e seguro".
} 
disso, as partes nas quais esse Programa está organizado - a saber, leitura, gramática e exercícios - nos levam a pensar que este livro Español Básico era, na verdade, um curso pensado para desenvolver a habilidade de leitura e, portanto, favorecer o acesso à bibliografia produzida em $\mathrm{LE}^{167}$. Ante tais reflexões, interpretamos que está operando, na materialidade linguística do título e do subtítulo desse instrumento de Calleja Álvarez, a contradição instalada historicamente a partir da Introdução da Gramática de Nascentes e mediante a já referida negação e que ressoou, também, na Exposição da Reforma Capanema ${ }^{168}$. De nossa perspectiva, no instrumento de Calleja Álvarez, essa contradição está, explicitamente, vinculada ao espaço de enunciação escolar, funcionando, inclusive como um fator determinante da relação dos alunos brasileiros com o estudo da LE.

Em suma, para as reflexões que acabamos de apresentar, relacionamos a contradição que identificamos no instrumento linguístico de Calleja Álvarez - a partir do título Español básico vinculado à especificação de seu subtítulo Cursos clássico e científico e ao seu Programa, que interpretamos funcionar como a introdução dessa obra - a outras duas textualidades já analisadas nesta primeira parte - a Exposição de Motivos da Reforma Capanema e a Introdução à Gramática de Nascentes. Tal movimento analítico nos permite inferir que este instrumento de Calleja Álvarez, em específico, materializa as condições de produção da LE, tanto em relação à configuração dessa língua na grade curricular da educação brasileira - como uma disciplina oficial da mesma -; quanto e, sobretudo, em relação às condições da mesma no "real" da escola: isto é, mesmo sendo uma disciplina oficial no currículo das instituições de ensino brasileiras regulares, o estudo dessa língua dava-se por apenas um ano.

\footnotetext{
${ }^{167}$ A esse respeito, aludimos a uma sequência (SdG_b) da entrevista da prof ${ }^{a}$ González, o qual já abordamos no Capítulo 1, em que ela referia-se às recorrentes práticas de leitura em LE que os alunos tinham que fazer, já desde cedo, para realizar trabalhos e pesquisas escolares.

${ }^{168}$ Lembremos que a ressonância dessa contradição na referida Exposição pôde ser identificada no enunciado que determinava que o estudo da LE devesse ocorrer "não pela rama e autodidaticamente." em relação com as determinações da Reforma Capanema de 1942 de que esse mesmo estudo seria por apenas um ano do secundário.
} 
Ainda em relação à análise dos sentidos que identificamos serem filiados ao funcionamento da memória discursiva sobre a LE e seu ensino-aprendizagem a partir do Programa do livro Español básico de Álvarez Calleja, destacamos uma terceira sequência:

SdCA_c: $\quad$ I - Leitura:

2. De excertos dos maiores escritores espanhóis e hispano-americanos, de forma que fiquem conhecidas as mais importantes obras e as características das literaturas de língua espanhola. (CALLEJA ÁLVAREZ, 1953, p.7, grifos nossos).

Com base nos fragmentos que grifamos, detectamos que na textualidade do Programa do instrumento linguístico em tela ressoam sentidos relacionados ao valor dos escritores espanhóis e hispano-americamos e, portanto, da riqueza de bibliografia produzida em língua espanhola. Tais sentidos, conforme já analisamos, haviam sido projetados pela Exposição de Motivos da Reforma Capanema de 1942 - especificamente pelo fragmento que caracterizava o espanhol como uma língua "de grande riqueza bibliográfica". Por fim, para finalizar o enfoque ao Programa do livro Español básico de Álvarez Calleja, consideramos pertinente apontar que não detectamos a projeção de sentidos para a LE que a vinculem ao número de falantes, que estava presente tanto nos instrumentos anteriores, de Nascentes e de Becker, quanto no discurso jurídico da Exposição de Motivos da Reforma Capanema.

Ante o exposto, passaremos ao próximo instrumento também de relevância para o ensino-aprendizagem da LE nas escolas, mesmo tendo sido lançado em um período (1969) em que essa língua não era mais uma disciplina obrigatória da grande curricular escolar brasileira.

\subsection{O Curso Práctico de Español de Francisco Frigério}

Dando continuidade a esse percurso a fim de observar os sentidos mobilizados na memória discursiva sobre a LE no Brasil, especialmente no espaço escolar, selecionamos outro instrumento linguístico, titulado Curso práctico de español, de autoria de Francisco 
Frigério e cuja $1^{a}$ edição foi publicada em 1969. Para nossa análise, como já antecipamos, trabalharemos com a $4^{\mathrm{a}}$ edição, de 1977. Esse autor era um professor concursado do Colégio Estadual do Paraná e que teve sua contribuição ao ensino de língua espanhola no Brasil reconhecida - sendo necessário esclarecer que tal reconhecimento se materializou como introdução do próprio instrumento - por Gabriel Espino Gutiérrez, catedrático aposentado de Língua e Literatura espanhola do Instituto Nacional Fr. Luis de León de Salamanca.

Na parte introdutória deste instrumento linguístico, abordaremos o texto que apresenta o autor e sua obra e que - sob o título Las aportaciones del Profesor D. Francisco Frigério a la didáctica de la lengua española - foi escrito pelo referido catedrático Espino Gutiérrez ${ }^{169}$. Diferentemente dos textos introdutórios dos outros instrumentos que analisamos, aqui, temos a visão de um sujeito que consideramos como "duplamente externo", uma vez que não é responsável pela autoria da obra e também não é brasileiro. Trata-se de um estrangeiro que analisa não só o instrumento linguístico em questão, como também o ensino da língua espanhola no Brasil.

Em relação a esse texto, recortamos duas sequências para iniciar nossa análise:

SdF_a: Gozan los libros escritos por el profesor Frigério, para la enseñanza del español, del privilegio que supone el que los alumnos que van a manejarlos, y sobre los que ha de ejercerse la labor profesoral, parten de una lengua hermana, y de una estructura análoga a aquélla cuyo aprendizaje emprenden. [...]

SdF_b: En efecto, la gran cercanía y parentesco entre ambas lenguas románicas: el portugués y el español, permite a los alumnos brasileños seguir el estudio de éste, casi el mismo camino utilizado en el conocimiento y adquisición de la lengua materna ${ }^{170}$ (FRIGÉRIO, 1977, p.3, grifos nossos).

Nessas sequências, destacamos fragmentos a partir dos quais identificamos a ressonância do sentido de "semelhança" entre o português o espanhol, fragmentos estes que, de nossa perspectiva, especificam a esse sentido de "semelhança", pois o projetam a partir de

\footnotetext{
${ }^{169}$ No anexo E, deste trabalho, é possível ter acesso ao texto em sua íntegra.

${ }^{170}$ Consideremos válido notar que, pela primeira vez, encontramos na introdução dos instrumentos linguísticos de espanhol que analisamos a referência à relação do sujeito brasileiro com sua língua, por meio da expressão língua materna.
} 
uma relação de "parentesco", especificamente de "irmandade", entre ambas as línguas que permitiriam, inclusive, aos alunos brasileiros, aprender a LE "casi” pelo "mismo camino utilizado en el conocimiento y adquisición” do português (antecipada como sendo a língua materna desses aprendizes).

Outro dos sentidos que identificamos no discurso sobre o Curso práctico de Frigério e que consideramos válido salientar é o de que o espanhol era uma língua que precisava ser "usada corretamente", conforme destacamos na sequência abaixo:

SdF_c: Al final del libro, un amplio apéndice gramatical recoge en forma sistemática, sencilla ${ }^{171}$ y con gran rigor científico, los paradigmas y las nociones gramaticales que no han sido anotadas a través de los textos, y son necesarias para el uso correcto del castellano (cf. FRIGÉRIO ${ }^{172}$, grifos nossos).

De nossa perspectiva, é relevante colocar o sentido projetado nos fragmentos que grifamos na SdF_c em relação com dizeres de outras duas textualidades que já analisamos nesta primeira parte de nossa dissertação, a saber: a afirmação da Introdução da Gramática de Nascentes de que seria "de grande vantagem para os brasileiros o conhecimento não perfunctório" da LE; e, sobretudo, a observação da Exposição de Motivos da Reforma Capanema a respeito de que o estudo do espanhol não deveria ocorrer "pela rama e autodidaticamente". Por meio dessa relação entre dizeres de diferentes textualidades, podemos identificar que ressoa, nesse texto introdutório ao Curso Práctico de Frigério, o sentido de necessidade de um estudo não feito "pela rama e autodidaticamente", mas realizado mediante materiais, tais como "un amplio apéndice gramatical" que aparece especificado com sintagmas tais como "forma sistemática" e "con gran rigor científico". Sentido este, que de nossa perspectiva, entra em relação com o "uso" ("correcto”) dessa língua.

\footnotetext{
${ }^{171}$ De nossa perspectiva, no termo "sencilla" já se antecipa o deslocamento do sentido de "facilidade" da LE em si para as práticas de ensino-aprendizagem adotadas e/ou desenvolvidas para essa língua.

172 Ibidem.
} 
Outro dos sentidos que ressoam no Curso Práctico de Frigério é o de língua cujo ensino deve focar-se no contraste com o português, que identificamos na seguinte sequência:

SdF_d: Con especial cuidado busca el autor facilitar a sus alumnos brasileños el aprendizaje de la lengua castellana, resaltando el paralelismo que existe en la estructura general, en el vocabulario, en la morfología, régimen de construcción entre la lengua materna y la de Cervantes, sin dejar de anotar con precisión las divergencias que entre ellas se advierten. Para la mayor eficacia de este cotejo, se propone con frecuencia una práctica utilísima: la versión de párrafos castellanos al portugués y viceversa (FRIGÉRIO, 1977, p.3, grifos nossos).

$\mathrm{Na}$ materialidade linguística desta sequência, notamos que se recupera a maneira de interpretar o ensino-aprendizagem da LE, no Brasil, fundada na Introdução da Gramática de Nascentes, como vinculado, fundamentalmente, à comparação entre essa língua e o português.

A partir dessa sequência, observamos também a ressonância do sentido de língua de grande valor e riqueza literária e cultural, porém, neste caso, mediante as designações "la lengua castellana" y "la [lengua] de Cervantes", cujos termos "castellana" e "de Cervantes" para um brasileiro, remetem, simbolicamente, à Espanha. A esse respeito, consideramos que os sentidos projetados pelos referidos fragmentos nos permitem antecipar uma possível filiação por parte deste instrumento linguístico a abordar a língua espanhola a partir da variante que se vincula, imaginariamente, à Espanha.

Ainda em relação à SdF_d, destacamos o enunciado "busca el autor facilitar a sus alumnos brasileños el aprendizaje”, no qual, de nossa perspectiva, ressoa o sentido de facilidade, porém não vinculado à língua espanhola em si, mas à sua aprendizagem, ou seja, ao método ou à forma pela qual essa aprendizagem será mediada. Para analisar os sentidos desse enunciado, mobilizamos outra sequência da introdução Curso Práctico de Frigério, que apresentamos a seguir:

SdF_e: En suma: el tratado Curso Práctico de Español del profesor Frigério, cumple perfectamente con el precepto horaciano de enseñar deleitando ${ }^{173}$ (FRIGÉRIO, 1977, p.4, grifos nossos)

${ }^{173}$ Ibidem. 
A partir do fragmento que grifamos nesta sequência, inferimos que o sentido de "facilidade", projetado no discurso da Gramática de Nascentes e que passou a funcionar na memória discursiva sobre a LE no Brasil, é retomado no discurso introdutório do Curso práctico de Frigério que estamos abordando, porém sua projeção é deslocada da língua à(s) prática(s) de ensino-aprendizagem da mesma, que por serem facilitadores teriam o efeito de "deleitar" os alunos.

Ante essa análise, observamos que o texto introdutório ao Curso práctico de español de Frigério sinaliza um "deslocamento" do sentido de facilidade, visto que este passa a ser um atributo das práticas de ensino-aprendizagem e não apenas da língua, práticas estas que são filiadas ao efeito de "deleite". Nesse deslocamento, interpretamos que se abre a possibilidade de que novos deslizamentos de sentido passem a significar a língua espanhola.

À luz das reflexões que acabamos de formular e das análises de diferentes instrumentos linguísticos que realizamos até este ponto, podemos destacar, fundamentalmente, o discurso dois desses instrumentos: a Introdução da Gramática de Nascentes e o texto introdutório do Curso Práctico de Frigério. Destacamos a Introdução da Gramática de Nascentes por consideramos que esta se caracterizou, conforme nossa análise, como um discurso fundador (e, inclusive, como já dissemos, como um discurso fundacional) que direcionou os dizeres sobre o espanhol, no Brasil, aos sentidos da série dicotômica "semelhança" e "facilidade"/ "diferença" e "dificuldade", a qual exploramos. O efeito disto, no espaço do ensino aprendizagem de LE em contexto escolar, foi a repetição de um gesto também instaurado por essa discursividade: a interpretação focada na comparação e no destaque das diferenças entre essa língua e o português. Já no texto introdutório do Curso Práctico de Frigério, reconhecemos uma relevância especial por entender que o mesmo, embora ainda coloque em funcionamento a contradição histórica fundada na Introdução da Gramática de Nascentes, marca, ou ao menos sinaliza, uma (re)orientação dos dizeres de "facilidade" de modo que este 
sentido não seria apenas um atributo da LE, mas uma necessidade que deveria perpassar as práticas de ensino-aprendizagem, antecipando, o "deleite" do aluno.

Neste ponto, passaremos então à análise do último instrumento deste Capítulo, a coleção didática Vamos a Hablar, que é a que corresponde a um contexto mais imediato ao da publicação de nosso objeto central, foco da segunda parte desta dissertação.

\subsection{A coleção Vamos a Hablar, publicada pela editora Ática.}

O instrumento que abordaremos neste item, a coleção didática de LE Vamos a Hablar, teve sua primeira edição publicada no final da década de 80 . Nesse sentido pensamos que, de certa forma, tal coleção representaria um rumo em direção a nosso objeto central, o qual abordaremos na segunda parte desta dissertação, por ter sido lançada em um contexto de enunciação mais imediato a ele. A esse respeito, salientamos ainda que, neste estudo, trabalharemos com a $4^{\text {a }}$ edição dessa obra, publicada no começo da década de 90, especificamente em 1992, visto que - como já adiantamos - não tivemos acesso à primeira.

Ademais, assim como procedemos com os instrumentos linguísticos anteriores, esclarecemos que selecionamos a coleção Vamos a hablar devido ao fato de que a mesma seja considerada como pioneira ${ }^{174}$ no mercado editorial brasileiro por ter sido a primeira coleção publicada por uma editora nacional de grande porte, a Ática, e desenvolvida em quatro

\footnotetext{
${ }^{174}$ No site da referida editora, faz-se referência a essa obra como tendo o caráter de pioneirismo:

Obra pioneira no ensino de espanhol, especialmente dirigida a alunos brasileiros. Amplamente testada em sala de aula, alia sólida estrutura gramatical à possibilidade de rica expressão oral.

Aproveita as facilidades oferecidas pela semelhança entre o espanhol e o português e evita as dificuldades trazidas por essa semelhança.

Trabalha as construções mais genuínas e próprias do espanhol, a pronúncia mais exata e as locuções mais naturais e expressivas.

Cada lição combina propostas didáticas diversas e complementares, para que o aluno se expresse, converse e até mesmo discuta, em espanhol (Disponível em: $<$ http://www.atica.com.br/catalogo/?i=850803590X> Acesso em 10.mai.2010).
} 
volumes a fim de atender aos quatro anos do ensino fundamental II. Aspecto este que, de certa forma, permite-nos considerar que a mesma tenha tido relevância no ensino-aprendizagem da língua espanhola em contexto escolar.

A proposta dessa coleção foi desenvolvida pela Consejería de Educación da embaixada da Espanha no Brasil, a partir de experiências do ensino de espanhol para alunos brasileiros e sob autoria de Felipe B. Pedraza Jiménez e Milagro Rodríguez Cáceres, assessores lingüísticos do Ministério de Educação e Ciência da Espanha. A partir dessas especificações indicadas na capa e em uma carta escrita por José Luis Crespo ${ }^{175}$, embaixador da Espanha na época, detectamos novamente uma relação que se estabelece entre o espanhol e a Espanha; nos referimos na verdade ao lugar que é dado a esse país com relação a essa língua ${ }^{176}$.

Feitos os esclarecimentos iniciais a respeito deste instrumento linguístico, procedemos à análise de seu texto introdutório, que é titulado de Presentación ${ }^{177}$ e está assinado pelos autores já mencionados. Para tanto, destacamos a seguinte sequência:

\begin{abstract}
SdVH_a ${ }^{178}$ : Vamos a Hablar es un método de español creado para atender las peculiares necesidades de los alumnos lusoparlantes y, en especial, de los brasileños. Hemos tratado de aprovechar las facilidades que nos ofrece la semejanza de las dos lenguas y de esquivar los escollos que encierra esa misma cercanía. El ritmo es, como parece lógico, el que exige un alumnado que puede avanzar con rapidez en el dominio del nuevo idioma (JIMÉNEZ; CÁCERES, 1992, p.6, grifos nossos).
\end{abstract}

\footnotetext{
${ }^{175}$ Esclarecemos que, nessa carta, José Luís Crespo faz algumas considerações sobre o contexto do ensino do espanhol no Brasil, que, devido aos efeitos causados pelas LDBs de 1961 e 1971, já trabalhados no primeiro capítulo desta dissertação, estava passando por um processo de reimplantação nas escolas e universidades; explicita a necessidade de um método diferenciado de ensino de espanhol para estudantes de língua portuguesa, devido à semelhança entre ambas as línguas e parabeniza e agradece à equipe que participou do desenvolvimento dessa obra.

${ }^{176}$ Esse lugar, como mostramos, aparecia também em Nascentes por meio da associação do espanhol à língua do "reino".

${ }^{177}$ No anexo F deste trabalho, é possível ter acesso ao texto de Presentación em sua íntegra.

${ }^{178}$ As sequências dessa coleção serão indicadas pela sigla Sd, referente à Sequência discursiva, e as iniciais do título da coleção Vamos a Hablar, acompanhadas pelas letras do alfabeto em minúscula que as ordenam. Não as identificaremos mais a partir da inicial do sobrenome do autor, visto que, este instrumento já está vinculado, de maneira mais específica, a um aparato editorial e possui a dimensão de uma coleção. Assim o entenderemos, também, para indicar as sequências da coleção Español sin Fronteras, foco da segunda parte desta dissertação.
} 
Analisando essa primeira sequência, identificamos a ressonância de dizeres que projetam sentidos de "facilidade" em relação a LE a partir da ênfase na "semelhança" entre essa língua e o português. Entretanto, notamos também, uma continuidade do movimento de "deslocamento" que identificamos no texto introdutório à obra de Frigério. Ao afirmar que essa coleção procurou "aprovechar las facilidades que nos ofrece la semejanza de las dos lenguas" (o espanhol e o português) e, também, "esquivar los escollos que encierra esa misma cercanía”, entendemos que essa coleção apresenta-se como um método "facilitador", ou seja, o sentido de "facilidade" aparece, aí, vinculado à LE, mas também à prática de seu ensino. E, inclusive, destacamos que no discurso desta Presentación vincula-se à "facilidade" tanto da LE quanto do método adotado para seu ensino, o sentido de "rapidez", que aparece aqui sob o efeito de um "pré-construído" a partir do fragmento "como es lógico"179.

Ainda a respeito da SdVH_a, interpretamos nesses fragmentos um gesto de mobilizar a comparação com a língua portuguesa a fim de evitar o confronto entre esta e a língua a ser ensinada, passando para o professor e, consequentemente, para o aluno, a imagem de que aprender línguas é um processo sem conflitos (cf. CORACINI, 2003, p.142). Em nosso estudo, estes sentidos adquirem uma espessura significativa, quando pensamos na relação específica do brasileiro com a LE que foi, historicamente, determinada pelo sentido de "facilidade", conforme mostramos ao longo de nossas análises.

À análise desta primeira sequência vinculamos uma segunda, na qual se esclarecem características referentes ao método adotado por essa coleção didática.

SdVH_b: Nuestro método quiere ser una invitación a que el alumno se exprese, intervenga en clase, converse con sus compañeros $e$ incluso discuta apasionadamente...en español. Junto a esta faceta y para evitar que se derive inconscientemente hacia una jerga informe (el portuñol), insistimos en algunas cuestiones fonéticas, morfosintáticas y léxicas fundamentales que

\footnotetext{
${ }^{179}$ Mediante esta observação, conseguimos ver que, nestas partes introdutórias que analisamos, aparecem dizeres ou imagens que, provavelmente, eram de circulação mais ampla (isto é no espaço de enunciação brasileiro de modo geral e não especificamente no escolar) o que nos permite interpretar a memória discursiva sobre o espanhol num horizonte, também, mais amplo.
} 
perfilan con claridad los rasgos de la lengua española. Las técnicas comunicativas deben aliarse a las propuestas de carácter estructural para conseguir una mayor eficacia en el proceso de aprendizaje; de la misma forma que la expresión oral, prioritaria en todos los casos, se enriquece y afianza con ejercicios escritos adecuadamente dosificados (ibid., grifos nossos).

Observamos, nesta sequência, dizeres que recuperam os sentidos associados ao espanhol em textos introdutórios de instrumentos linguísticos que já abordamos. Notamos que, ademais de destacar, para o professor, que ele deve aproveitar as facilidades dessa língua e seguir o ritmo rápido de aprendizagem de seus os alunos, como analisamos na SdVH_a, o método deve funcionar como um "convite" (expresso na SdVH_b pelo significante “invitación”), e não como uma obrigação ou uma necessidade, para esse aluno. E, esse "convite" deve, ainda, como resultado, despertar a paixão no aluno em meio ao processo de ensino-aprendizagem da LE. A partir desses sentidos de "convite" e de "paixão", que entram em relação com a LE, percebemos um efeito de "informalidade", efeito este que, já antecipamos, terá relevância na análise das apresentações de nosso objeto central e em nossas considerações finais.

No entanto, embora os sentidos de "convite" e de "paixão" sejam mobilizados, essa relação de "informalidade" com a língua espanhola, projetada como um efeito dos mesmos, entra em tensão, de nossa perspectiva, com a advertência a respeito de se evitar "uma jerga informe”, ou seja, o "portuñol" - que, com base em Celada (2002) pode ser entendido como o expoente máximo da relação marcada pela ilusão de competência espontânea que o brasileiro teve com a LE. Nesse sentido, ponderamos que, ainda que os textos introdutórios de outros instrumentos linguísticos tenham ressaltado a importância de "aprender a usar o espanhol" corretamente (cf. FRIGÉRIO, 1977) ou de não conhecer a LE apenas de maneira "perfunctória” (cf. NASCENTES, 1934), pela primeira vez, na materialidade linguísticodiscursiva desta instância que abordamos - a dos instrumentos linguísticos -, aparece a restrição ao "portunhol" e, por conseguinte, aos efeitos de sentido que a ele se vinculam na 
determinação da relação do brasileiro com a LE. No entanto, também é preciso dizer que termo "portunhol", nesse intradiscurso, parece mais do que nada estar designando a produção que realiza o aprendiz que, em certas teorias, seria chamada de interlíngua e que, de nossa perspectiva, poderia ser denominada de "entremeio" (cf. CELADA, 2002, p.18), pensando no lugar de estar "entre" "línguas" que o sujeito ocupa no processo de aprendizado de uma língua estrangeira.

A esse respeito, é válido atentarmos para a contradição que se produz no interior da textualidade dessa Presentación, especificamente entre os sentidos projetados pela SdVH_a e pela SdVH_b. Ou seja, por um lado, enfatiza-se, na SdVH_a, o sentido de "facilidade" e "rapidez" na aprendizagem do espanhol por alunos brasileiros devido à "semelhança" com o português; e, por outro, adverte-se que o "portunhol" seja evitado. Sendo assim, inferimos que estamos diante do que consideramos ser um indício de um processo em que os sentidos de "semelhança" e de "facilidade" começam a ser submetidos a um certo questionamento, ou, à luz da teoria do discurso, a uma certa tensão no interior da memória discursiva sobre a LE e seu ensino-aprendizagem no Brasil. Em outras palavras, podemos dizer que a relação de sentidos entre as sequências que recortamos e a contradição que identificamos no eixo intradiscursivo dessa textualidade nos sinalizam indícios de um deslocamento nas rotinas da memória sobre o espanhol que se instalou na relação do brasileiro com o ensinoaprendizagem dessa língua. Ou seja, a própria inflexão do sentido dessa língua (do modo como se significou a mesma) ao processo ensino-aprendizagem abriu espaço a esse movimento de tensão na memória discursiva.

Dando continuidade a nossa análise, salientamos também que conforme os dizeres das SdVH_a e SdVH_b dessa Presentación, para que se alcancem todos os objetivos nelas expressos a saber - "rapidez", "facilidade", "convite", "prazer" e "aprendizagem eficaz" sem interferências do "portunhol" - o método dessa coleção propõe-se a aliar técnicas 
comunicativas a propostas estruturais, priorizando a expressão oral, conforme o próprio título da obra, Vamos a Hablar, e apresentando exercícios escritos, que enriqueceriam a expressão oral, de maneira "dosificada", conforme dito na SdVH_b. É válido notar, nesse adjetivo, uma metáfora que associa o método de aplicar exercícios escritos à maneira de se aplicar medicamentos, isto é, por doses que evitam um desconforto ou uma dor.

Assim sendo, podemos inferir, por fim, que na Presentación de Vamos a Hablar, materializa-se um movimento na direção de afastar sentidos que representem dificuldades durante o processo de ensino-aprendizado dessa língua, que fazia parte da série de sentidos dicotômicos, instaurada a partir da Introdução da Gramática de Nascentes. Ou seja, caso a maneira como esse aprendizado se apresentasse ao aluno não fosse "adecuadamente dosificada", esse processo poderia tornar-se "doloroso" para o mesmo, posto que lhe exigiria sacrifícios e esforços, sentidos estes que não estiveram presentes na memória discursiva sobre a língua espanhola no Brasil.

Em suma, com base na análise desse último instrumento linguístico que selecionamos para este Capítulo, podemos inferir que há nele uma certa continuidade em relação ao "deslocamento" que identificamos ser sinalizado no texto de introdução do Curso Práctico de Frigério. Assim interpretamos, pois, ao mesmo tempo em que se começa a afastar do espanhol os sentidos de "semelhança" ao português e de consequente "facilidade" (reforçada pela advertência de se evitar o "portunhol), notamos um (re)direcionamento desses mesmos sentidos e efeitos para as práticas de ensino-aprendizagem de LE, que deveriam "esquivar los escollos" e "dosificar" o estudo da LE a fim de evitar o confronto do aluno com as “dificuldades" dessa língua, de possibilitar-lhe a aprendizagem da mesma com "rapidez", de apresentá-la como um "convite", de despertar a "paixão" durante o processo de ensinoaprendizagem, enfim, poderíamos inferir, de "deleitá-lo". 


\section{Rumo a um Español sin Fronteras}

Por fim, para passar à segunda parte desta dissertação, é necessário que retomemos algumas considerações com relação aos dois capítulos que compõem esta primeira parte. Neste que estamos encerrando, consideramos pertinente recuperar a ideia de que interpretamos o funcionamento da memória discursiva sobre a LE, especialmente, pensando nas inflexões às quais a mesma foi submetida em sua relação com o ensino-aprendizagem e, mais especificamente, no espaço escolar. Para tanto, abordamos textos introdutórios de diferentes instrumentos linguísticos produzidos no Brasil entre as décadas de 20 e 80 dos anos 90.

A partir da análise dessas textualidades pudemos interpretar o funcionamento da referida memória, na qual determinamos a "fundação" de uma série de sentidos para a LE na instância dos instrumentos linguísticos dessa língua, série esta que foi submetida a processos de repetição/deslocamento. Nessa direção, podemos indicar uma formação discursiva (doravante também referida por FD), tal como a entende Pêcheux (1988, p.160). Com base nesse conceito, ponderamos que, em nossa análise, conseguimos identificar "um domínio de saber, constituído de enunciados discursivos, que representam um modo de relacionar-se com a ideologia vigente, regulando o que pode e deve ser dito" (cf. PÊCHEUX ${ }^{180}$ ). "Domínio de saberes" no qual a LE é filiada, fundamentalmente, à série de sentidos da dicotomia "paradoxal" instalada na Introdução da Gramática Nascentes: "facilidade" e "semelhança" / "diferença" e "dificuldade". Nessa textualidade, tal dicotomia entrava em relação direta com os sentidos de língua "de estudo não-perfunctório" e "cuja aprendizagem se dá pelo contraste com o português" e operava, assim, o que analisamos como uma contradição constituída historicamente e determinante da relação do brasileiro com e LE.

${ }^{180}$ Ibidem. 
A esse respeito, observamos que nos textos introdutórios dos outros instrumentos linguísticos, essa série de sentidos foi submetida a um processo, fundamentalmente, marcado pela repetição e, portanto, deu continuidade ao funcionamento da contradição ao qual nos referimos no interior da formação discursiva relacionada à LE em contexto de ensinoaprendizagem.

Esse é o caso do que observamos no Programa do livro Español Básico de Álvarez Calleja, na introdução ao Curso Práctico de Frigério e na Presentación de Vamos a Hablar. ${ }^{181}$ Em cada um desses instrumentos, a contradição funcionou de modo específico, tal como apareceu nas respectivas análises que desenvolvemos. Porém, nesse processo que designamos, o trabalho de repetição foi submetido, também, a certos deslocamentos: ressaltamos, em primeiro lugar, o produzido na introdução do Curso Práctico de Frigério, no qual o sentido de "facilidade" é deslocado da LE para as práticas adotadas para o ensino-aprendizagem da mesma e, ainda, submetido a um embate mediante a projeção de sentidos de necessidade de um estudo dessa língua "com grande rigor científico" e "de forma sistemática"; e, em segundo lugar, a continuidade dada a esse "deslocamento" na Presentación de Vamos a Hablar, conforme analisamos. Assim, inferimos que em meio à repetição e ao deslocamento, verificados em um mesmo eixo de enunciação, a contradição que exploramos continuava em funcionamento e no domínio da mesma formação discursiva.

Os outros sentidos que apareceram vinculados, mesmo que não de forma direta, a essa dicotomia são: "língua de um reino" (e portanto língua da Espanha) e "língua falada por 80 milhões de pessoas no globo" (na Gramática de Nascentes). Este último sentido é retomado e especificado no Manual de Becker a partir do texto que registra e especifica o número de

\footnotetext{
${ }^{181}$ No Manual de Idel Becker, na parte introdutória, essa dicotomia não se fez presente. No trabalho de Celada (2002), a autora (que contempla o instrumento de modo integral) o interpreta como um elemento "articulador" entre a Gramática de Nascentes e a dimensão do ensino de LE, mais ligada à escola de forma geral.
} 
falantes em cada continente e subcontinente ${ }^{182}$; na parte introdutória deste Manual encontramos, também, o sentido de "língua de vinculação aos países hispano-americanos".

Diante dessa retomada que realizamos, parece-nos importante, a partir da perspectiva que nos abre o Capítulo 2, recuperar e, em parte ressignificar, dois aspectos. O primeiro deles tem a ver com o fato de que estamos em condições de dizer que, na textualidade da Exposição de Motivos da Reforma Capanema (1942), está instalada, também, a contradição que aqui trabalhamos, sobretudo a partir do fragmento que interpretamos especialmente "não pela rama e autodidaticamente, mas de modo metódico e seguro" e da determinação de que o tempo de estudo seria de um ano. Esses sentidos se vincularam a uma função dupla que teve, de acordo com nossa interpretação, a inclusão da língua no currículo escolar: por um lado, de “completar" a estatística de três línguas estrangeiras e, por outro, "complementar" a "carência de recursos culturais" produzidos ou disponíveis na língua nacional, no caso, a língua portuguesa. O segundo desses dois aspectos tem a ver com que, dentro do que Rodrigues (2010) chama de "processo de desoficialização das línguas na escola", e que começaria com a LDB de 61, se inscreveria a sanção da lei 11.161, de 2005. Nesta, as fissuras que analisamos, com base nas interpretações dessa mesma autora, nos permitem ver que a implantação da língua espanhola está e estará sujeita a diferentes interpretações e formas de regulamentação. De fato, o texto legal abre brechas que comprometem a função curricular da LE como disciplina, aproximando-a de um estatuto extracurricular. Esses dois aspectos têm a ver com o efeito de "informalidade" do qual já falamos neste trabalho e que retomaríamos dizendo que se relaciona com a observação que fizemos na Introdução de nossa dissertação acerca do estatuto que caracterizamos como "não-disciplinar" da LE no funcionamento do real em certas escolas - estatuto este que seria uma expressão clara do referido processo de “desoficialização" (cf. RODRIGUES, 2010) das línguas estrangeiras na escola. Aliás, tal

\footnotetext{
${ }^{182}$ Lembramos que em nossa análise, a repetição desse sentido referente ao número de falantes da LE sob um grau de especificação foi por nós interpretado como sinalizador de um gesto que filiava o espanhol ao imaginário de língua veicular.
} 
processo atinge seu ápice na própria materialidade do texto da referida lei. Por fim, a própria contradição instaurada pela dicotomia paradoxal "semelhança" e "facilidade" / "diferença" e "dificuldade" pareceria estar produzindo efeitos que ainda afetam seu estatuto enquanto disciplina. Mas esta é apenas uma hipótese que retomaremos ao final desta pesquisa.

Neste ponto, passamos à segunda parte desta dissertação que será uma continuidade desta em dois sentidos. Em primeiro lugar, porque continuaremos abrindo o arquivo dos instrumentos linguísticos para nos centrar especialmente num determinado - a coleção Español sin fronteras; e, em segundo lugar, porque a formação discursiva aqui interpretada será um elemento importante na análise que desenvolveremos. 


\section{PARTE II \\ COM FOCO EM "ESPAÑOL SIN FRONTERAS"}

Dando prosseguimento ao estudo da questão central de nossa pesquisa - interpretar os sentidos aos que se filia a LE no espaço escolar -, nesta parte, nosso foco será a coleção didática Español sin fronteras, publicada pela editora Scipione em 1996, e suas duas reedições, em 2002 e 2007. Para sua análise, recortamos três elementos dentre os que compõem sua estrutura paratextual - o título, as capas e as apresentações - e, com base nesse recorte, organizamos os dois capítulos que compõem esta parte.

No Capítulo 3, abordaremos o título Español sin fronteras a partir de dois movimentos analíticos que entrelaçaremos em nossa interpretação. $\mathrm{O}$ primeiro será o de interpretar as marcas linguístico-discursivas em sua materialidade. E o segundo consistirá em colocar esse título em relações de sentido com o intradiscurso - ou seja, com as capas e com recortes das apresentações das três edições dessa coleção -; e com o interdiscurso - isto é, com sentidos que circulam na memória discursiva sobre a LE no Brasil e com as condições de produção dessa língua em cada um dos diferentes momentos em que é publicada e reeditada. O fato de confirmar que os sentidos aí produzidos inscrevem esse discurso na formação discursiva interpretada no encerramento do Capítulo 2 nos levará a, centrar-nos, no Capítulo 4, na apresentação da terceira edição. A análise desta nos favorecerá a realização de algumas considerações a respeito do funcionamento dessa formação discursiva e, por tanto, do funcionamento dos sentidos na memória discursiva sobre o espanhol no Brasil. 


\section{Capítulo 3}

\section{COMO SE PROJETA UM “ESPAÑOL SIN FRONTERAS” EM CADA EDIÇÃO}

"O novo não está no que é dito, mas no acontecimento de sua volta" (FOUCAULT, 2008, p. 26).

Español sin fronteras é uma coleção didática voltada para o ensino de LE para brasileiros, publicada pela editora Scipione, em 1996, e reeditada duas vezes, em 2002 e 2007. A partir dessa coleção didática e de suas reformulações, daremos continuidade ao estudo do funcionamento da memória discursiva sobre a língua espanhola no Brasil, focando alguns de seus elementos paratextuais - tal como especificamos na Introdução desta segunda parte - e interpretando como tais elementos significam à luz das diferentes condições de produção.

Dentre as diversas possibilidades de análise de uma coleção didática, optamos por recortar elementos paratextuais, considerando a formulação de Genette (2009, p. 9) segundo a qual a paratextualidade ${ }^{183}$ é aquilo por meio de que um texto se torna livro e se propõe como tal ao público e, de maneira mais específica, a seus leitores. A esse respeito, o autor acrescenta $^{184}$ que um texto, ao tornar-se livro, é geralmente reforçado por um determinado número de produções paratextuais, sejam elas verbais ou não verbais que, de certa forma, o cercam e o prolongam, a fim de garantir sua presença no mundo, sua "recepção" e seu consumo.

Sendo assim, cientes de que nosso objeto é um texto que instrumentaliza o ensino da

\footnotetext{
${ }^{183}$ O autor oferece como alternativa desse conceito a designação "transcendência textual" que, de alguma forma, materializa a imagem que o paratexto mantém com relação ao texto.

${ }^{184}$ Ibidem.
} 
LE (e instrumentaliza essa língua para seu ensino), e que está configurado sob a forma de livro - inclusive, de uma coleção - pareceu-nos pertinente analisar como esta "se propõe a seus leitores" de modo a garantir sua "presença no mundo" e sua "recepção" - como diria o próprio Genette (2009). No caso específico de nossa pesquisa, analisaremos como, em tal coleção, é significada a (presença da) língua espanhola no espaço da escola.

Uma vez definido nosso recorte, ou seja, os elementos paratextuais da coleção didática $E S F$, resta-nos especificar quais, dentre esses elementos, podem ser profícuos para nosso estudo. De acordo com Genette, os elementos constitutivos do paratexto são:

Título, capa, subtítulos, intertítulos; prefácios, preâmbulos, apresentação, etc.; notas marginais, de rodapé, de fim; epígrafes; ilustrações; dedicatórias, tira, jaqueta [cobertura], e vários outros tipos de sinais acessórios, [...] (GENETTE, 2009, p. 10).

De nossa perspectiva, entendemos que todos os elementos constitutivos do paratexto são discursivos e que, neles, se materializa e funciona o que Orlandi (2007a, p. 41-42) - com base em conceitos fundadores da AD, já presentes no texto de Pêcheux (1969) - chama de jogo de imagens, inerente a todo processo discursivo. De acordo com esses autores, tais imagens são construídas ao longo do processo discursivo, o que nos estimula a ponderar que, no caso de um texto, apresentado sob a forma de um livro, estas já poderiam ser detectadas no paratexto. Referimo-nos, especificamente a respeito de nosso objeto, às imagens com relação: à língua espanhola, ao(s) leitor(es) dessa coleção - nesse caso, consideramos o(s) aluno(s), $\mathrm{o}(\mathrm{s})$ professor(es) e a equipe de coordenação ${ }^{185}$ - à própria coleção, às autoras da mesma, ao ensino da LE no Brasil, dentre as principais.

No que concerne à variedade de elementos paratextuais, o próprio Genette $(2009, \mathrm{p}$. 55) considera que a instância cuja força discursiva é mais rica e imediata é o título, visto que

\footnotetext{
${ }^{185}$ Esclarecemos que consideramos a equipe de coordenação também como um possível leitor dessa coleção didática, visto que, em muitas instituições de ensino, observa-se a prática de analisar o material didático a ser adotado durante o ano letivo em conjunto. Ou seja, o professor, ou o grupo de professores de uma mesma área, junto com os coordenadores, avaliam qual material se adéqua às necessidades e à proposta pedagógica específica da escola.
} 
este é um elemento de recepção direcionado não apenas aos leitores do livro, mas ao público de maneira geral. Isto é, entendemos que, por estar no que podemos chamar de "rosto" do livro, esse elemento é o que interpela o leitor desde o primeiro contato. No caso específico das práticas escolares, esse efeito disparador assume uma dimensão especial, visto que, na maioria das vezes, o primeiro contato que o leitor - seja ele o aluno, o professor ou a equipe de coordenação - tem com o livro didático é por meio do título informado na lista de material, no caso do primeiro leitor que especificamos, ou do catálogo da editora, no caso dos dois últimos. Considerando, portanto, que o título pode funcionar como o disparador "imediato" (cf. GENETTE, 2009), do jogo de imagens (cf. ORLANDI, 2007a, p. 41-42 e PÊCHEUX, 1969) relacionadas à língua espanhola no contexto escolar, o selecionamos como o primeiro elemento paratextual que enfocaremos em nossa análise.

Com base nas considerações formuladas por Genette ${ }^{186}$ e retomadas aqui sob uma perspectiva discursiva, pensamos que, dentre os espaços em que o título é geralmente apresentado, a capa poderia ser considerada o principal deles ${ }^{187}$. Ademais, inferimos que esta também pode ser caracterizada como um elemento paratextual que abrange esse campo de recepção mais amplo, destinado "não apenas aos leitores, mas ao público de modo geral" e que está intrinsecamente relacionada ao título, inclusive permitindo, reforçando e ampliando o jogo de imagens ${ }^{188}$ por ele disparado. Assim, ponderamos que não seria pertinente analisar o título desconsiderando esse seu vínculo com a capa e, portanto, a selecionamos como nosso segundo elemento paratextual de análise.

Ainda no que concerne ao título e à capa, é válido expor a formulação de Genette

\footnotetext{
186 Ibidem.

${ }^{187}$ Dizemos principal, pois além de ser apresentado na capa, o título é retomado na quarta capa, na folha de rosto e na ficha catalográfica. Porém, esses elementos não estão ao alcance imediato do olhar do leitor. Ademais, é válido considerar que quando a encadernação não é do tipo espiralado, o título é indicado, também, na lombada do livro. Dessa maneira, podemos inferir que a capa é o espaço em que o título sempre aparecerá, independentemente de sua encadernação, e que, de nossa perspectiva, permite ao mesmo ter uma força discursiva "imediata" tal como considera Genette (2009, p. 55).

${ }^{188}$ Cf. ORLANDI e PÊCHEUX, ibidem.
} 
(2009, p. 210) de que tais elementos estariam localizados em uma zona que ele define como "peritexto editorial”, sob responsabilidade direta e principal, mas não exclusiva, do editor. Ou seja, a autoria de tais elementos paratextuais não seria apenas do(s) autor(es), mas partilhada entre este(s) e o(s) editor(es).

Assim sendo, refletindo sobre a questão que norteia essa pesquisa - os sentidos filiados à LE em contexto escolar - pareceu-nos pertinente analisar algum elemento paratextual mais específico, isto é, que, por um lado, estivesse direcionado ao leitor/usuário do livro didático na escola, seja o aluno, o professor ou a equipe de coordenação; e, por outro, se relacionasse mais com o escopo do dizer do autor ou do dizer pelo qual o autor se responsabiliza mais diretamente, inclusive deixando o registro de sua assinatura ${ }^{189}$.

Ante tal perspectiva, selecionamos o terceiro elemento paratextual que enfocaremos: a apresentação. Esta é analisada por Genette (2009, p. 145) sob a designação de prefácio e, segundo ele, seria "toda espécie de texto preliminar, que consiste num discurso produzido a propósito do texto que antecede". O estudioso ${ }^{190}$ acrescenta que esse elemento paratextual realiza um tipo de "pré-interpretação" do livro, declarando as intenções do escritor, ainda que seja alógrafo, isto é, escrito por outra pessoa, porém em nome do autor e com a anuência deste. Ante tais formulações, consideramos pertinente relacionar a apresentação com o conceito de discurso sobre, tal como entendido por Mariani (1998, p. $60^{191}$ apud RODRIGUES, 2010, p. 199). Para a autora, o discurso sobre além de funcionar como organizador "em termos de uma memória", também projeta "desdobramentos futuros", pois “digere" para o leitor aquilo sobre o que se fala. Nesse sentido reforçamos nossa compreensão da apresentação como um elemento paratextual que, em relação aos outros dois já selecionados, está mais vinculado não apenas ao dizer do autor, mas também, a seu trabalho:

\footnotetext{
${ }^{189}$ No caso específico da coleção que analisamos, Español sin fronteras, antecipamos que as apresentações da mesma são assinadas, ao final, pelas autoras.

${ }^{190}$ Ibidem.

191 A obra de Mariani mobilizada na pesquisa de Rodrigues é: MARIANI, B. (1998). O PCB e a imprensa: os comunistas no imaginário dos jornais (1922-1989). Rio de Janeiro/Campinas: Revan/Ed. da Unicamp.
} 
o de "organizar", "projetar" e "digerir" o objeto que apresenta a seu leitor.

Definidos os elementos a partir dos quais analisaremos a coleção didática $E S F$, podemos passar ao estudo dos mesmos, conforme a organização que já apresentamos neste item.

\section{COM FOCO NO TÍTULO ESPAÑOL SIN FRONTERAS}

Antes de iniciar a análise proposta neste item, consideramos válido esclarecer que o dividimos em duas partes. Na primeira, nos centramos no movimento de análise da materialidade linguística do referido título; e, na segunda, mobilizamos um conceito teórico que não só funcionará como um articulador entre as interpretações referentes a essa materialidade e as relações de sentido que estabelecemos entre o título, as capas e recortes da apresentação da primeira edição, mas também perpassará a análise que desenvolvemos sobre o objeto que focamos ao longo desta segunda parte: a coleção $E S F$.

\subsection{O título e sua dupla determinação}

Dando impulso, portanto, ao movimento que determinamos para primeira parte deste item, percebemos, na materialidade linguística do título, um efeito de determinação dada à língua espanhola a partir do sintagma que o predica: sin fronteras. Segundo Henry (1990, p. 58): “todo discurso 'concreto' é duplamente determinado: de um lado, pelas formações ideológicas que relacionam este discurso a formações discursivas definidas; de outro, pela autonomia relativa da língua". Essa formulação será a que orientará o trabalho de interpretação que aqui realizaremos ao analisar o título de nossa coleção - Español sin 
fronteras. Abordaremos, pois, esse enunciado explorando o conceito de dupla determinação, tal como propõe Henry ${ }^{192}$.

Começamos, então, pela primeira marca linguística que nos permite identificar uma determinação: a negação formulada no sintagma sin fronteras. Analisando essa marca, mobilizamos as reflexões de Indursky (1997, p. 217), segundo a qual os marcadores de negação funcionam, para o analista do discurso, como uma pista do discurso-outro (D2) que não pode ou não deve estar explicitado no discurso (D1), em nosso caso, o título da coleção. Indursky ${ }^{193}$ esclarece, ainda, que é possível perceber a presença implícita desse discurso-outro por meio da transformação metodológica da negação em uma afirmação. Assim sendo, em nosso caso, teríamos a transformação de Español sin fronteras em Español con fronteras. A partir dessa conversão, podemos perceber que, simultaneamente ${ }^{194}$, entram em relação com o sintagma español não apenas o sentido de ausência de fronteiras, mas também o da existência das mesmas. Nesse sentido, entendemos que a negação funciona para determinar a língua espanhola, seja pelo sentido negado, seja pelo discurso-outro, identificado pela transformação em uma afirmação.

É válido atentar, ainda, que, embora a negação construída no sintagma sin fronteras produza um efeito de determinação linguística para “español”, também é possível identificar na mesma um efeito que funciona como uma generalização, posto que o termo fronteras não é submetido a nenhuma especificação. Ou seja, o que entendemos é que há uma determinação, porém esta não se completa totalmente na/pela língua, visto que diversos sentidos podem ser filiados ao termo fronteras, tais como: sin fronteras geográficas, políticas, lingüísticas, culturales, sociales, regionales, etc.

\footnotetext{
192 Ibidem.

${ }^{193}$ Ibidem.

194 Antecipamos que essa afirmação, à qual chegamos a partir da transformação metodológica da negação sin fronteras, será explorada mais adiante e produzirá sentidos produtivos para nossas análises. E, inclusive, a partir dela poderemos perceber que essa simultaneidade - segundo a qual se negam fronteiras que estão, ao mesmo tempo, presentes - não é da ordem de um tempo lógico, mas da ordem da história.
} 
Para avançar na interpretação do funcionamento do que Henry (1990, p. 58) caracterizada como dupla determinação e que estamos analisando em relação ao título da coleção ESF, consideramos pertinente mobilizar o conceito de silêncio fundador, formulado por Orlandi (1992, p. 70). A autora define silêncio fundador como a própria condição da produção de sentido e insiste em dizer que tal conceito não deve ser pensado como uma falta, isto é, uma ausência de sons e de significados, mas em termos de um horizonte, entendido como um mecanismo, que põe em funcionamento o conjunto do que é preciso não dizer para poder dizer ${ }^{195}$. Nesse sentido, podemos entender que a negação sin fronteras determina linguisticamente español e, olhada a partir do conceito de silêncio fundador, remete-nos à exterioridade, isto é, ao que não está dito na língua, ao que está fora dela, porém produzindo sentidos na mesma: o que conforme Orlandi ${ }^{196}$ seria o "não dizer” para “poder dizer”.

Essa passagem à exterioridade nos permite avançar na interpretação da dupla determinação, tal como formulada por Henry ${ }^{197}$. E, para tanto, é preciso considerar e reconhecer a interação língua-ideologia-sujeito a partir das reflexões que Indursky (1997, p. 178) formula ao abordar o conceito de determinação discursiva.

Com base nessa reflexão, reconhecemos no enunciado sin fronteras uma determinação que, a partir de nossa interpretação, remete a uma formação discursiva relacionada à globalização. A fim de explorar essa formação discursiva, baseamo-nos em estudos realizados no campo das ciências sociais por Ianni (2001, p. 14), que pesquisa sobre o processo de globalização iniciado no final do século XX. Esse autor afirma que "a descoberta de que o globo terrestre não é mais apenas uma figura astronômica, e sim histórica ${ }^{198}$, abala o modo de ser, pensar, fabular.". E, nesse sentido, observa que, em meio a esse “clima”, "a reflexão e a

\footnotetext{
195 cf. ORLANDI, ibidem., p. 76.

196 Ibidem.

197 Op. cit.

198 No processo de globalização que esse autor estuda a partir do século XX, a expressão "figura histórica" é utilizada por ele para referir-se à descoberta de que a terra, antes considerada apenas uma figura astronômica, passa a ser entendida como um mundo, isto é, como um território no qual todos se encontram relacionados e atrelados, diferenciados e antagônicos (cf. IANNI, 2001, p. 13).
} 
imaginação não só caminham de par em par como multiplicam metáforas, imagens, figuras, parábolas, alegorias, destinadas a dar conta do que está acontecendo, das realidades não codificadas, das surpresas inimaginadas" ${ }^{\prime 199}$. Dentre as figuras de linguagem mencionadas por Ianni $^{200}$, o autor destaca algumas metáforas e expressões descritivas e interpretativas que circulam pela bibliografia sobre a globalização, tais como: "economia-mundo", "sistemamundo", "shopping center global", "nova visão internacional do trabalho", moeda global, “mundo sem fronteiras", "tecnocosmo", "hegemonia global”, etc.

Considerando, pois, todos os conceitos que mobilizamos até o momento e a partir de diferentes autores - a saber dupla determinação, negação, silêncio fundador, formação discursiva referente à globalização e determinação discursiva - podemos formular nossa interpretação a respeito do predicado sin fronteras do título da coleção ESF. De nossa perspectiva, consideramos que esse enunciado entra em relação com a série de sentidos que aparecem em enunciações de tom eufórico e promissor dentro do já referido processo de globalização. Em outras palavras, podemos dizer que, a partir das marcas linguísticas presentes na materialidade linguística do título ESF - marcas de determinação e de negação, fundamentalmente, permeadas pelo funcionamento do silêncio fundador - foi possível estabelecer a relação com a formação discursiva relacionada à globalização e, assim, podemos concluir que, no enunciado sin fronteras, opera uma projeção que "determina" a língua espanhola como língua veicular, língua da globalização, de acesso ao trabalho, à economia, à tecnologia, etc. Nesse sentido, consideramos que as marcas linguísticas que identificamos nesse título materializam, de nosso ponto de vista, um "gesto" que dá corpo a essa projeção sobre a LE no âmbito discursivo que circulará no espaço escolar. Antes de passar ao segundo item deste capítulo, antecipamos que interpretaremos esse "gesto", a partir de um conceito da $\mathrm{AD}$, como uma tomada de posição.

\footnotetext{
${ }^{199}$ Ibidem.

${ }^{200}$ Ibidem., p. 15.
} 


\subsection{O título como indício}

Ante a análise que desenvolvemos, impulsionados pelo conceito de dupla determinação, de Henry (1990, p. 58) e explorado a partir das marcas linguísticas do título Español sin fronteras, podemos proceder à passagem para o segundo item deste capítulo. Lembramos que, neste, colocaremos o título em relações de sentido com outros dois elementos paratextuais da coleção ESF - as capas e alguns recortes das apresentações - e mobilizaremos, ainda, aspectos relacionados às condições de produção da língua espanhola no Brasil e, também, específicas ao seu ensino-aprendizagem no contexto escolar e a cada momento de reedição dessa coleção.

Para proceder a tal passagem, à luz da análise realizada na primeira aproximação ao título que acabamos de fazer, consideramos pertinente introduzir o conceito de tomada de posição da $\mathrm{AD}$, elaborado por Pêcheux (2006, p. 57). O que nos guia nessa direção é a formulação mediante a qual o referido autor considera que as tomadas de posição funcionam como "momentos de interpretação" entendidos "enquanto atos que surgem como efeitos de identificação assumidos e não negados" e que "somente podem ser detectados através de descrições regulares de montagens discursivas". ${ }^{201}$ Em nossa análise, esses "efeitos de identificação" serão trabalhados com relação ao "domínio de saberes", isto é, à formação discursiva que interpretamos no final do capítulo 2 da primeira parte desta dissertação.

Nesse sentido, ponderamos que a publicação e as reedições dessa coleção - entendida em sua totalidade, porém analisadas, nesta dissertação, a partir dos três elementos paratextuais que já definimos - detectaremos "gestos de interpretação" (por parte do sujeito do discurso) que entrarão em relação com essa tomada de posição e nos permitirão falar de identificação (ou não) com o domínio de saberes da referida formação discursiva. Neste ponto, é preciso

\footnotetext{
${ }^{201}$ Ibidem.
} 
lembrar que, para Pêcheux (1988, p. 160), esta não é estável e pode apresentar-se sob diferentes "modalidades" que envolvem desde tensões e deslocamentos até rupturas. Sendo assim, acreditamos que, ao relacionar o título com elementos paratextuais que foram reformulados - e que já especificamos: capas e apresentações -, poderemos observar os sentidos projetados pelo sujeito do discurso dessa coleção em diferentes condições de produção. E, a partir desses sentidos, analisar como o sujeito "assume" sua "identificação" com a FD que se organizou sobre língua espanhola e seu ensino no Brasil, isto é, sob qual "modalidade" "surge o efeito de identificação" com a mesma, nas diferentes condições de produção ou reedições da coleção em foco. Para tanto, é válido que apresentemos quais são as três modalidades de tomada de posição formuladas por Pêcheux (1988, p. 213 apud INDURSKY, 2008), visto que, a partir desse momento, as mobilizaremos ao longo das análises, tanto as desenvolvidas nos próximos itens deste capítulo, quanto as que desenvolvemos no Capítulo 4.

A primeira das modalidades remete ao que o autor ${ }^{202}$ designou de superposição, ou seja, uma identificação plena, por parte do sujeito do discurso, com a forma-sujeito da formação discursiva que o afeta ou com a qual se identifica. Nesse caso, a forma-sujeito é considerada como dotada de uma unicidade. Já a segunda seria entendida, por Pêcheux ${ }^{203}$, como uma contra-identificação; ou seja, a forma-sujeito não seria única, podendo desdobrarse em diferentes posições-sujeito. Assim sendo, haveria uma tensão entre o sujeito do discurso e a posição-sujeito dominante de sua formação discursiva, o que suscitaria distanciamento, questionamento, dúvida, contestação ou revolta por parte desse sujeito com relação a sua FD. E, por fim, a terceira, representaria uma desidentificação, isto é, uma ruptura, por parte do sujeito do discurso, com o domínio do saber em que estava inscrito (ou seja, com sua FD) e com todas as posições-sujeito em que a forma-sujeito dessa FD se

\footnotetext{
${ }^{202}$ Ibidem.

${ }^{203}$ Ibidem.
} 
desdobra. Essa ruptura seria provocada pela identificação do sujeito do discurso com outra formação discursiva.

A partir da interpretação dessas três modalidades de "tomada de posição" propostas por Pêcheux (1988), Indursky (2008) infere que nem todos os sentidos que deslizam, no discurso e em determinadas condições de produção, provocam uma ruptura "radical" e “definitiva" com a ideologia já instituída de modo a ser capaz de instaurar uma nova formação discursiva e produzir novos saberes. Nesse sentido, a autora entende que apenas essa forma de ruptura, que ela caracteriza como "radical" e "definitiva", isto é, a tomada de posição do sujeito do discurso que represente uma "desidentificação" com a forma-sujeito de sua FD pode ser considerada um acontecimento discursivo, tal como Pêcheux propõe em sua obra de 1990, “O discurso, estrutura ou acontecimento". Já nos casos em que se observa somente uma contra-identificação por parte do sujeito do discurso, não há, segundo a autora, uma ruptura e sim uma maneira tensa com a qual o mesmo se relaciona com a ideologia (ou seja, com a posição-sujeito) predominante na FD que o interpela. Isto é, o sujeito do discurso não se "desidentifica" com sua FD, apenas apresenta "contestações ou questionamentos" com relação a algumas posições-sujeito da mesma, sobretudo a dominante. Neste caso, Indursky (2008) interpreta que o acontecimento não é discursivo, mas apenas enunciativo.

Neste ponto, estamos em condições de passar ao item seguinte e estabelecer as relações de sentido entre o título e os outros elementos paratextuais que já determinados.

\section{O TÍTULO EM NOVAS RELAÇÕES DE SENTIDO}

Conforme exposto na introdução deste capítulo, neste segundo item, dedicar-nos-emos a perceber relações entre a interpretação realizada sobre o título e os sentidos que a elas se vinculam, em cada uma das três edições de ESF a partir das capas, de recortes da 
apresentação e de aspectos relacionados às condições de produção da LE no Brasil.

Sendo assim, para organizar nossas análises, dividimos este segundo item em três subtítulos - 2.1. para a primeira edição; 2.2. para a segunda edição e 2.3. para a terceira edição - e os formulamos a partir de uma oposição sintático-semântica entre os termos "por que" (pronome interrogativo) e "porque" (conjunção subordinativa explicativa). Por essa oposição, queremos remeter, primeiro - a partir do pronome interrogativo - à FD, já referida no final do Capítulo 2 e a partir da qual a LE no Brasil não se vinculava a uma necessidade e a uma formalização de seu estudo, dando margem a questionamentos sobre por que estudá-la. E, segundo, - a partir da conjunção subordinativa explicativa - queremos remeter, com base nos elementos paratextuais por nós analisados, às diversas necessidades ou justificativas que a coleção ESF projeta com relação ao espanhol a fim de filiar essa língua ao estatuto disciplinar nas escolas brasileiras.

\subsection{Primeira edição: Estudar espanhol por quêe? / Porque pode despertar interesse}

\subsubsection{A relação com as capas}

Com relação à primeira edição, observamos que todas as capas são iguais ${ }^{204}$, apresentando alterações apenas nas cores de fundo (volume 1, azul; volume 2, rosa; volume 3, verde e volume 4, laranja). Ademais, notamos que elas apresentam as mesmas imagens, a saber: toureiro lidando com touro, o rosto de uma índia peruana, a ilustração do mascote dos Jogos Olímpicos de Barcelona em 1994, A Torre del Oro em Sevilha, uma cena de um casal dançando tango no bairro argentino La Boca, a pirâmide Chichen Itza no México e um casal

\footnotetext{
${ }^{204}$ As capas dos quatro volumes da primeira edição estão disponíveis no anexo H.
} 
de dançarinos típicos mexicanos ${ }^{205}$. Essas imagens, entretanto, não aparecem na mesma ordem nas capas dos quatro volumes. Estas são modificadas, de nossa perspectiva, de acordo com uma certa lógica: como se diversos filmes de máquina fotográfica estivessem sendo desenrolados e só algumas fotos fossem as escolhidas para serem reveladas em cada volume. Formulamos essa interpretação com base na observação de que todas as capas apresentam algumas imagens coloridas, como se tivessem sido reveladas e, outras, em preto e branco, como marca-d'água, para aproximar-se a um negativo de filme de máquina fotográfica no qual temos dificuldade de ver com clareza qual foto está em cada espaço. Ainda a respeito do design gráfico das capas da primeira edição, é válido ressaltar que, na ponta dessas tiras de filme, pode-se visualizar o verso das mesmas, que apresenta as cores da bandeira espanhola amarelo e vermelho - como se estivessem perpassando constitutivamente todas as imagens que descrevemos.

A partir dessa série de relações que estabelecemos, ponderamos, em um primeiro momento, que as imagens apresentadas e o design gráfico criado para as mesmas - ou seja, sua inserção em tiras de filmes fotográficos - fazem referência à imagem do turista que viaja por diferentes países tirando fotos. Logo, a predicação sin fronteras do título da coleção poderia ser especificada pelo sintagma geográficas e, assim, teríamos: sin fronteras geográficas. Ou seja, as fronteiras seriam associadas a limites entre territórios de países onde o espanhol é a língua oficial e que poderiam ser ultrapassadas pelos brasileiros, público leitor ao qual essa coleção se destina, tanto por meio de viagens (um deslocamento no espaço) quanto por meio da aprendizagem da língua espanhola (um deslocamento necessariamente metafórico).

Com base nessas interpretações iniciais, identificamos, nessas capas, um equívoco, o qual consideramos produtivo analisar. Entendemos que o design gráfico materializa um gesto

\footnotetext{
${ }^{205}$ A especificação dessas imagens foi feita com base nas indicações iconográficas fornecidas no próprio livro didático.
} 
em direção a filiar a língua espanhola aos sentidos de diversidade (sobretudo linguística e cultural), a partir da variedade de imagens que fazem referência não apenas à Espanha, mas a outros países hispanofalantes da América, tais como: Peru, Argentina e México. Entretanto, tais sentidos escorregam e derivam para outros, evidenciando a relação tensa do simbólico com o real que interpela os sujeitos (cf. ORLANDI, 2007a, p. 53). De nossa perspectiva, esse equívoco se materializa, justamente, no verso das tiras dos filmes fotográficos, ao qual já fizemos referência, por meio das cores, amarelo e vermelho, que são também as cores utilizadas para o título da coleção e que entram em relação com a bandeira da Espanha.

Destarte, para analisar os sentidos aos quais esse equívoco nos remete, consideramos pertinente aludir a um estudo em que Orlandi (2005) reflete sobre o fato de que, no campo dos países colonizados, línguas como o português ou o espanhol, na América Latina, funcionam em uma identidade que a autora chama de "dupla". Para Orlandi (2005), opera um gesto de colonização linguística que homogeneíza as variantes dessas duas línguas faladas nos países colonizados com relação às variantes que se falam em Portugal e na Espanha, desconsiderando, assim, as marcas de historicização inscritas nelas. A autora reafirma suas considerações, com base em reflexões sobre o português do Brasil e o português de Portugal, destacando a necessidade de reconhecer o que ela chama de "heterogeneidade linguística" e que define ao afirmar que:

[...] joga em nossa língua um fundo falso em que o "mesmo" abriga, no entanto, um "outro", um diferente histórico que o constitui ainda que na aparência do "mesmo": o português brasileiro e o português português se recobrem como se fossem a mesma língua, mas não são. Produzem discursos distintos, significam diferentemente (ORLANDI, 2005, grifo nosso).

Embora a autora, nesse fragmento específico, refira-se à língua portuguesa, como já antecipamos, consideramos pertinente associar sua definição às capas da primeira edição da coleção ESF. Nestas, interpretamos que o "fundo falso" do qual fala Orlandi ${ }^{206}$ está materializado por meio do design em que se apresentam seus elementos gráficos: tiras

\footnotetext{
${ }^{206}$ Ibidem.
} 
fotográficas com imagens que, além de remeter à própria Espanha, remetem, também aos países hispanofalantes da América - e, metonimicamente, portanto, à "variedade" da língua espanhola - em cujo verso estão as cores da bandeira da Espanha que aludem ao Império e ao processo de colonização que este levou adiante em território americano.

De nossa perspectiva, esse "fundo falso", do qual fala Orlandi (2005), permite-nos identificar como funciona, nas capas da primeira edição de $E S F$, o equívoco e, assim, direcionar nossa interpretação rumo ao que nos sinaliza o funcionamento de uma contradição, tal como entendida por Pêcheux (1990, p. 253). Notamos, nessas capas, que a LE é referida a partir do "diverso", mas numa relação de subordinação à bandeira da Espanha, elemento que - como acabamos de adiantar - significa, nesse contexto, com forte expressividade histórica. Tal relação (de subordinação), de nossa perspectiva, atinge o ápice de sua materialização no design do título da coleção cujas cores - as letras escritas em amarelo, sob um fundo vermelho - reforçam a referência à bandeira da nação espanhola.

Realizamos tais interpretações à luz, justamente, da definição do conceito de contradição: nesta, segundo Pêcheux ${ }^{207}$, funciona necessariamente uma relação de desigualdade e de subordinação. Reconhecemos tal relação na materialidade das capas, quando vinculamos a série de aspectos que acabamos de detectar à história, à exterioridade.

A partir do que dizemos, inferimos que essas capas projetam sobre a "Espanha" um "peso" maior, o qual, podemos identificar tanto pelo não verbal quanto pelo verbal, na materialidade das mesmas. A partir do não verbal, notamos que a bandeira perpassa as imagens que remetem a outros países hispanofalantes, unindo-os em uma mesma "tira de filme fotográfico" e, por metonímia, inferimos que “em uma mesma língua”. Já em relação ao verbal, especificamente, ao título da coleção, identificamos que as cores dessa bandeira são utilizadas nas letras e no fundo do mesmo, que, por sua vez, está composto pelo nome da

${ }^{207}$ Ibidem. 
língua falada nos países representados pelas imagens: Español. Nesse sentido, ponderamos que as cores da bandeira da Espanha estão perpassando e, assim, projetando uma relação de desigualdade e de subordinação não apenas entre os países hispanofalantes da América e a Espanha, mas também entre as variantes da língua espanhola faladas nos países hispanoamericanos e "a variante" vinculada, imaginariamente, à língua (sempre heterogênea) falada na Espanha. Ante tais reflexões, consideramos pertinente concluir que, nas capas da primeira edição, a história opera, de maneira específica, mediante os sentidos que se relacionam com o processo de conquista e de colonização linguística pelo qual os países da América atualmente conhecidos como hispanofalantes - passaram.

Neste ponto, consideramos pertinente colocar o predicado sin fronteras, do título da coleção em foco, em relações de sentido com as reflexões que formulamos para, assim, chegarmos numa possível especificação: sin fronteras "linguísticas". A esse respeito, ponderamos que é possível identificar dois efeitos de sentido projetados por esse sintagma especificador. Um desses efeitos detectado na análise da materialidade das capas poderia indicar "variedade linguística"; ou seja, o sentido de que, a partir dessa coleção, seria possível entrar em contato com as diferentes variantes da língua espanhola, ou, ao menos, com as variantes predominantes em diferentes países hispanofalantes. Entretanto, segundo o efeito de sentido detectado pelo gesto analítico, em que consideramos o funcionamento da contradição (cf. PÊCHEUX, 1990, p. 253) - e, portanto, da história - identificamos o confronto com o gesto de colonização, que tende a abordar o que vê como "variedades linguísticas" sob a “aparência do mesmo", aludindo às palavras de Orlandi (2005).

Assim, retomando o predicado sin fronteras vinculado ao especificador linguísticas, poderíamos observar que os sentidos projetados nessa capa antecipam que a língua espanhola seria abordada, na coleção $E S F$, sem que as "fronteiras" dos países hispanofalantes representem uma barreira, de modo que todas as diferenças dialetais e regionais poderiam ser 
contempladas nesse material didático. E, ainda, pensando nas reflexões que tecemos a partir do conceito de contradição, também identificamos uma antecipação de que, caso as variantes da LE sejam trabalhadas nessa coleção, a abordagem das mesmas será em uma relação de desigualdade e/ou subordinação à variante filiada, imaginariamente, à Espanha. Dizemos "imaginariamente", como já antecipamos, pois sabemos que se trata apenas da projeção de uma das variantes que funciona, a partir de um pré-construído, como "a língua" dessa metrópole. Entendemos, portanto, que o título sin fronteras funciona, na materialidade das capas, numa relação de sentidos essencialmente contraditória a respeito da questão da heterogeneidade, a qual sabemos, a partir do lugar de analistas do discurso, que é constitutiva de uma língua (cf. SERRANI-INFANTE,1997, p. 2).

A partir da série de alusões disparadas pela materialidade das capas que analisamos, ponderamos que, além do especificador linguísticas para o predicado sin fronteras, este poderia ser determinado, também, pelo especificador culturales. Para interpretá-lo, podemos seguir duas direções, assim como procedemos com o especificador linguísticas. A primeira delas remete-nos a sentidos das variedades culturais, pois consideramos que as tiras de filmes de máquina fotográfica aludem à imagem do turista que viaja e conhece diversas manifestações culturais - metáfora do estudante que, por meio da aprendizagem da língua espanhola mediada pela coleção $E S F$, também terá acesso a tal diversidade.

No entanto, embora seja possível identificar a projeção de sentidos relacionados a uma variedade cultural, visto que há imagens de diferentes países hispanofalantes, a disposição gráfica dada a essas imagens criam, de acordo com nossa interpretação, o que Gasparini (2009, p. 2) chama de efeito museológico. Segundo o autor, esse efeito visa a que um objeto discursivo seja visto, porém sem ser compreendido, sem ser historicizado e culmina com a redução das culturas ao folclórico. Sob essa perspectiva, identificamos a projeção de sentidos que visam a desconstruir o efeito de diversidade cultural com relação aos 
países hispanofalantes, tanto a partir da capa, quanto a partir do predicado sin fronteras do título. Este projeta tais sentidos, fundamentalmente, por meio de uma de suas marcas linguísticas que interpretamos no item 1 deste capítulo: a negação. Já a capa o faz por meio do efeito museológico, formulado por Gasparini ${ }^{208}$, o qual aprofundaremos com base na pesquisa que De Nardi (2010) desenvolveu sobre a relação entre cultura e ensino-aprendizagem de línguas analisando materiais didáticos de língua espanhola.

Segundo a estudiosa, a cultura, a partir da vertente discursiva, deve ser concebida como um lugar de interpretação. A esse respeito, De Nardi ${ }^{209}$ aborda o conceito caráter crítico da cultura, de Chauí ${ }^{210}$, entendido como a possibilidade de que o sujeito desvende as aparências e interprete criticamente as práticas sociais e políticas. No entanto, em grande parte dos livros didáticos que De $\operatorname{Nardi}^{211}$ analisa, a estudiosa percebe que a abordagem dada à cultura do outro acaba produzindo um efeito de fragmentação, ou seja, uma redução do aspecto cultural a um amontoado de informações dispersas, negando à cultura seu caráter dinâmico e heterogêneo. A pesquisadora acrescenta, ainda, com base em Bosi $^{212}$, que esse movimento nos coloca no lugar de espectadores atônitos.

É esse o efeito que detectamos no predicado sin fronteras, do título da coleção, quando especificado, tal como propusemos, à luz da análise da materialidade não verbal das capas, pelo adjetivo culturales. Retomando, diríamos que, por um lado, a disposição das imagens de maneira aleatória remete-nos a essa caracterização de "amontoado de informações dispersas"213; e, por outro, sua apresentação em filmes fotográficos remete-nos a esse lugar de “espectadores atônitos" (cf. BOSI, 2000, apud. DE NARDI ${ }^{214}$ ) diante de uma série de fotos

\footnotetext{
208 Ibidem.

${ }^{209}$ Ibidem.

${ }^{210}$ A obra citada por De Nardi (2010) é: CHAUÍ, Marilena. (2006) Cidadania cultural. O direito à cultura. São Paulo: Editora Fundação Perseu Abramo.

211 Ibidem.

212 A obra citada por De Nardi (2010) é: BOSI, Alfredo (2000) Plural, mas não caótico. In. Cultura brasileira. Temas e situações. 4 ed. São Paulo: Ática, 2000, p. 7-16.

213 cf. DE NARDI, ibidem.

${ }^{214}$ Ibidem.
} 
dispostas de maneira fragmentada, o que não estimula a interpretação, mas apenas a observação do que Bosi ${ }^{215}$ chama de "espetáculo de variedades" e que - nós acrescentaríamos - apresentado sob o caráter pitoresco e folclorizado. Ademais, neste ponto, é válido retomar a ideia de que essa série dispersa e fragmentada de imagens aparece naquela relação de subordinação às cores da bandeira da Espanha que já analisamos, fato que, de acordo com nossa interpretação e à luz da contradição que já abordamos, afeta o "caráter dinâmico e heterogêneo" a partir do qual se deve entender a cultura.

Ante o exposto até o momento, retomamos os três possíveis determinantes que poderiam especificar o predicado sin fronteras, a saber: geográficas, lingüísticas e culturales. E, pela forma em que mobilizamos tais determinantes, seria possível dizer que a autoria desse título - de modo específico, na materialidade das capas - funciona sob o efeito de uma ilusão: a de significar a língua espanhola como um "todo", isto é, como algo passível de ser abordado e apreendido em sua totalidade.

Seguiremos, neste ponto, nosso percurso, em busca de sentidos que nos permitam interpretar a determinação dessas fronteras, porém agora colocando a análise do título (e das capas) em "relações de sentidos" com algumas sequências que recortamos da apresentação da primeira edição.

\subsubsection{A relação com a apresentação}

Apresentaremos, agora, a primeira sequência discursiva que recortamos da apresentação da primeira edição de $E S F^{216}$, designada por nós a partir da sigla $\operatorname{Sd} 1^{\text {a } \_a ~}$

\footnotetext{
215 Ibidem.

${ }^{216}$ Em nossas análises do título e das capas, realizadas ao longo deste terceiro capítulo, trabalharemos com alguns recortes dos textos de apresentação das três edições de Español sin fronteras que sempre serão apresentados, na íntegra, no anexo indicado. Com relação à apresentação da primeira edição que analisamos neste subitem, a mesmo está no anexo $\mathrm{G}$ deste trabalho.
} 
(sequência discursiva da $\mathbf{1}^{\mathrm{a}}$ edição $)^{217}$ :

Sd1 ${ }^{\text {a }}$ a:Recordamos hoje nossa dificuldade como professoras, anos atrás. Embora $o$ espanhol fosse para nós a "primeira língua materna", nos sentíamos desamparadas pela falta de material adequado ao ensino do idioma para alunos brasileiros. Naquela época, não havia muitas obras disponíveis, e as poucas existentes eram estrangeiras ou escritas por estrangeiros, que não dispunham do necessário conhecimento de português para avaliar as dificuldades do aluno brasileiro em relação ao aprendizado da língua espanhola [...] (JIMÉNEZ GARCÍA, M. L. A,; SANCHEZ HERNÁNDEZ, J. 1996, p. 4, grifos nossos).

Nesta sequência, destacamos fragmentos que nos permitem perceber algumas especificações para o predicado - sin fronteras - do título que estamos analisando. A partir da análise de tais fragmentos, notamos, também, a projeção de determinados sentidos com relação à posição discursiva ocupada pelas autoras dessa coleção, entendidas enquanto sujeitos do discurso. De nossa perspectiva, consideramos que esses sentidos vinculados à posição-autor sinalizam aspectos relevantes e produtivos para nossas análises. Portanto, procederemos à interpretação dos mesmos e, em seguida, retomaremos as especificações projetadas ao predicado do título $E S F$ a partir da $S d 1^{\mathrm{a}} \_$a.

Começaremos por abordar o funcionamento do sintagma "primeira língua materna", que aparece por nós grifado na $\mathrm{Sd}_{1}^{\mathrm{a}} \_\mathrm{a}$, mas também pelas autoras, que o colocaram entre aspas. Observamos que o adjetivo "primeira" caracteriza não o termo "língua" especificamente, mas o sintagma "língua materna". Ante essa observação, ponderamos que o sujeito do discurso, que nele se apresenta como um "nós" - e que fazemos coincidir com a assinatura registrada ao fim da apresentação: "as autoras" - se apresenta como possuindo mais de uma "língua materna" e estabelece, inclusive, uma ordem a partir da que especifica como sendo a "primeira": a língua espanhola. Já a língua que ocuparia a "segunda posição" como "materna" não é designada de forma explícita nesse texto. Porém, podemos determinar que é o português, a partir de dois aspectos que identificamos na textualidade de $\mathrm{Sd} 1^{\mathrm{a}} \_$a. $\mathrm{O}$ primeiro

\footnotetext{
${ }^{217}$ Esclarecemos que os recortes das apresentações que mobilizaremos ao longo do item 2 deste capítulo serão abordados como sequências discursivas e estas serão identificadas com a sigla 'Sd', à qual acrescentaremos o número que remete à edição da coleção $\operatorname{ESF}\left(1^{\mathrm{a}}, 2^{\mathrm{a}}\right.$ ou $\left.3^{\mathrm{a}}\right)$, correspondente ao respectivo recorte da apresentação. Ademais, utilizaremos letras minúsculas (a, b, c, etc.) para ordenar as sequências por nós recortadas.
} 
refere-se ao fato de que essa sequência, bem como a apresentação em sua totalidade, está escrita em português, o que nos permite supor, a essas autoras, um saber sobre essa língua. E o segundo aspecto relaciona-se à negação, formulada no segundo fragmento que destacamos

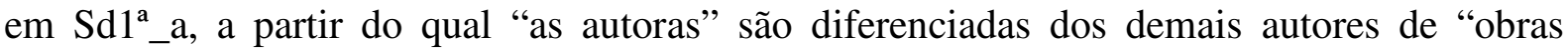
disponíveis" para o ensino de LE, os quais, segundo consta na própria textualidade, "não dispunham do necessário conhecimento de português para avaliar as dificuldades do aluno brasileiro em relação ao aprendizado da língua espanhola”. Interpretamos que esse conhecimento da língua portuguesa, caracterizado por meio da referida diferenciação e associado ao fato de que essa apresentação está escrita em português, aparece, na textualidade que analisamos, como sendo algo que "as autoras" possuem.

A análise dessa sequência nos faz perceber que o termo "língua materna" (e não simplesmente "língua") é aqui empregado a partir de um certo senso-comum e, assim, há uma certa exploração da força semântica e dos sentidos que o adjetivo "materna" guarda nesse funcionamento - isto é, sem que se considere a opacidade dessa expressão como conceito, do modo que vem sendo tratado no campo dos estudos da linguagem.

Para avançar em nossa interpretação, mobilizaremos o conceito de língua materna a partir de Revuz (1998) e o colocaremos em relação com a oposição entre "poliglota" e "polilingue", proposta por Amati-Mehler, Argentieri e Canestri ${ }^{218}$ (apud GRIGOLETTI, 2008). Segundo Revuz (1998, p. 215), há sempre uma primeira língua, que corresponde à língua da infância, isto é, aquela pela qual se teve acesso à linguagem. Esta seria, pois, a língua materna, que não necessariamente deve corresponder à língua da mãe. Ante essa definição e retomando o fragmento "primeira língua materna" da $\mathrm{Sd1}{ }^{\mathrm{a}} \mathrm{a}$, que estamos analisando, parece-nos pertinente considerar o que Grigoletti (2008, p. 3) aponta a respeito de diferenças na relação com a "língua materna". Essa pesquisadora analisa os sujeitos em

\footnotetext{
${ }^{218}$ A obra que Grigoletti (2008) se refere para mobilizar os conceitos de "poliglota" e "polilingue" é: AMATIMEHLER, J., ARGENTIERI, S., CANESTRI, J. (2005) A babel do inconsciente. Rio de Janeiro: Imago.
} 
condição bilíngue ou, como a mesma propõe, em condição multilíngue, isto é, expostos, desde sua infância, a mais de uma língua. Para analisar os casos de bilinguismo ou multilinguismo, Grigoletti $^{219}$ mobiliza as reflexões de Amati-Mehler, Argentieri e Canestri ${ }^{220}$, que contextualizam a condição desses sujeitos classificando-os em poliglotas ou polilingues. Para essa autora $^{221}$, estes seriam os sujeitos que tiveram acesso a mais de uma língua desde o seu nascimento e essas várias línguas funcionaram no nível de interlingualidade materna; já os poliglotas seriam os sujeitos que adquiriram outra ou outras línguas após a primeira infância ou após a aquisição da língua materna, sendo estas consideradas, no caso, como línguas estrangeiras.

Com base nos conceitos que mobilizamos, podemos considerar que a língua materna não deve coincidir necessariamente apenas com "uma" língua. Essa consideração pode ser entendida claramente a partir do que Amati-Mehler, Argentieri e Canestri ${ }^{22}$ designam como interlingualidade materna e que nós interpretamos como uma dimensão habitada por várias línguas, desde que estas tenham participado do acontecimento da introdução do sujeito na linguagem. ${ }^{223}$ Assim, não seria pertinente ordenar essas várias línguas como "primeira", “segunda", "terceira”, etc., visto que o sujeito estaria exposto a elas de maneira simultânea.

É, pois, a partir desta última consideração que fundamentamos nossa afirmação de que, na Sd1 a _a, o termo "língua materna" é mobilizado a partir da perspectiva do sensocomum que, inclusive, permite pensar em várias línguas maternas, numa sucessão que possibilitaria ordená-las, desconsiderando como se deu o processo de encontro/confronto (cf. REVUZ, 1998, p. 215) com cada uma delas.

Ante todo o exposto, reconhecemos, no fragmento analisado na $\mathrm{Sd} 1^{\mathrm{a}} \mathrm{a}$, o

\footnotetext{
219 Ibidem.

${ }^{220}$ Ibidem.

${ }^{221}$ Ibid., apud GRIGOLETTI, 2008, p .3.

${ }^{222}$ Ibidem.

${ }^{223}$ Melman (1992), a partir de uma visão menos ligada à constatação de se há, ou não, um contexto claro de várias línguas na infância do sujeito, fala de um inconsciente habitado por fragmentos de várias línguas.
} 
funcionamento de um jogo de antecipações imaginárias. Ou seja, consideramos que, a partir da autoria da coleção didática, são antecipadas determinadas imagens com relação ao leitor dessa coleção, seja ele o aluno, o professor ou a equipe de coordenação. Referimo-nos às imagens que esse leitor projeta sobre o ensino-aprendizagem de línguas, sobre o livro didático destinado a essa área de conhecimento e, neste caso específico, sobre o autor do mesmo. Como já vimos, de acordo com formulações de Pêcheux $(1969 \text {, p. } 83)^{224}$, todo processo discursivo supõe, por parte do locutor, uma antecipação das representações do interlocutor, sobre a qual se funda tal processo. Entendemos, então, que o sintagma "primeira língua materna" materializaria um jogo que se vincula à potência semântica do que Bertoldo (2003, p. 88-89) chama de "imaginário de falante nativo" ${ }^{225}$. No caso do fragmento que analisamos, esse imaginário se estende, também, à língua portuguesa, visto que podemos deduzir, a partir do significante "primeira", que ela também é considerada "materna" pelas autoras ${ }^{226}$. Dessa forma, se ampliaria e se reforçaria o efeito de legitimidade da autoria, perante o leitor e, por conseguinte, da coleção didática e da língua espanhola instrumentalizada na mesma.

Com base nessa análise, é possível indicar, ainda, o funcionamento de um deslizamento de sentidos - como forma que materializa o equívoco constitutivo do funcionamento da linguagem. Por aparecer nessa textualidade o sintagma "língua materna", sem estar vinculado ao conceito, opaco, trabalhado no campo dos estudos da linguagem, e aparecer qualificado mediante um adjetivo ordinal, os sentidos derivam, escorregam a outros

\footnotetext{
${ }^{224}$ Recordamos que, neste mesmo capítulo, vinculamos os conceitos de Pêcheux (1969) às formulações de Orlandi (2007a) para disparar reflexões que estamos desenvolvendo ao longo do mesmo.

${ }^{225}$ Bertoldo (ibidem) define esse imaginário como o daquele falante que sabe sua língua (entendida como a "língua primeira" pela qual teve acesso à linguagem) perfeitamente bem, podendo servir como parâmetro ou mesmo uma autoridade para dizer aquilo que está ou não correto em termos de fala e/ou gramática da língua.

${ }^{226}$ A esse respeito é válido considerar que o fato de projetar o "imaginário de falante nativo" para a língua espanhola produz um efeito que, de nossa perspectiva, abrange os três leitores que especificamos para um livro didático: aluno, professor e equipe de coordenação; visto que há uma tendência, predominante, porém, não homogênea, em valorizar a imagem do nativo no ensino-aprendizagem de línguas estrangeiras. Já no que tange ao "imaginário de falante nativo" para a língua portuguesa, entendemos que este se vincula, mais especificamente, ao professor e à coordenação - que tendem a antecipar com relação ao autor do livro didático um conhecimento das necessidades e dificuldades específicas dos alunos aos quais se destina sua obra, a fim de que seja capaz de orientar e auxiliar a prática docente.
} 
efeitos que não os provavelmente antecipados pelas "as autoras". O que estamos querendo dizer é que, ao ser estabelecida uma ordem para as línguas especificadas como "maternas", é possível interpretar, de acordo com esse elemento narrativo (biográfico), que o encontro/confronto das autoras com as mesmas não ocorreu de maneira simultânea. Logo, o efeito de sentidos projetado sobre os indivíduos do mundo ("as autoras") não corresponde à imagem de "nativas" em ambas as línguas - ou, nos termos de Lyons (987, p. 257-258), de bilíngues perfeitas ${ }^{227}$ - mas de bilíngues, isto é, sujeitos da linguagem que aprenderam uma “segunda língua" (ou uma língua estrangeira) após, e não em concomitância com, a aquisição da "primeira língua" (ou a língua materna) (cf. REVUZ, 1998, p. 215). Esse deslize tiraria, com relação ao português, esse poder que o fato de ser nativo asseguraria.

Estamos, neste ponto, preparados para passar à análise dos sentidos que podem especificar o predicado sin fronteras abordando, ainda, essa mesma sequência discursiva. Com base na referida sequência, podemos pensar o termo fronteras, do título, como metáfora de "dificuldades", a partir dos sentidos projetados nos fragmentos que aqui retomamos: "nos sentíamos desamparadas pela falta de material adequado ao ensino do idioma a alunos brasileiros." e "que não dispunham do necessário conhecimento de português para avaliar as dificuldades do aluno brasileiro em relação ao aprendizado da língua espanhola". Considerando os destaques que fizemos, inferimos que a relação metafórica que propomos para fronteras como "dificuldades" refere-se tanto aos professores, devido à falta de materiais didáticos adequados ao ensino LE, quanto aos alunos que, como brasileiros, apresentavam dificuldades específicas às quais os materiais estrangeiros não atendiam. Essa consideração também nos permite pensar que a negação do predicado sin fronteras, que identificamos no item 1 deste capítulo (e que vinculamos a uma marca que funciona como efeito do funcionamento do silêncio fundador), entraria em relação com a possibilidade de traçar um

${ }^{227}$ Conforme Lyons (1987, p. 257-258) é possível admitir, como ideal teórico, a possibilidade do bilinguismo perfeito definido como competência total em duas línguas, equivalente à competência que um falante nativo monolíngue tem em uma. 
limite, "um basta", para ambas as "dificuldades", ou seja, as dos professores (a falta de materiais didáticos adequados aos alunos brasileiros) e as dos alunos brasileiros (que não dispunham de materiais didáticos adequados às suas especificidades). A esse respeito, consideramos válido mobilizar outra sequência dessa apresentação a fim de que possamos formular novas reflexões:

Sd1 ${ }^{\mathbf{a}}$ b:Decidimos então criar o nosso próprio material, aproveitando tudo que chegava em nossas mãos: contos, poesias, letras de músicas, artigos de jornais ou de revistas, etc. Assim, de forma lúdica e descontraída, conseguíamos alcançar nosso objetivo, ou seja, levar o aluno a se interessar pela língua espanhola. Foi a partir de então que nos ocorreu a ideia de escrever uma obra didática de Espanhol, um material que atendesse às necessidades de nossos alunos e, principalmente, servisse de apoio para o professor. (JIMÉNEZ GARCÍA, M. L. A,; SANCHEZ HERNÁNDEZ, J., 1996, p. 4, grifo nosso).

Notamos, na Sd1 a _b, uma relação com a sequência anterior na qual percebemos que as autoras identificam-se com uma posição-sujeito "autoras" afetada pela dificuldade de ensinar espanhol no Brasil. Porém, nessa segunda sequência que recortamos, interpretamos que essa posição mostra-se como determinada não apenas pela falta de materiais adequados a alunos brasileiros, como aparece no dito da $\mathrm{Sd} 1^{\mathrm{a}}$ _a, mas, também, pela "falta de interesse" do aluno por essa língua; veja-se, nesse sentido, o enunciado que aparece na textualidade da $\mathrm{Sd} 1^{\mathrm{a}}$ _b, no qual se explicita o objetivo da produção do LD: "levar o aluno a se interessar pela língua espanhola". Objetivo este que, de nossa perspectiva e ante todo o que já pesquisamos e analisamos neste trabalho, não pode ser entendido como aquele característico a qualquer professor que visa despertar o interesse do aluno pela disciplina que ministra. Para desenvolver e aprofundar essa formulação, é preciso remeter às condições de produção observadas desde a década de 60 até o final da década de 80, que analisamos na Parte I desta dissertação.

À luz dessa análise, essas condições foram marcadas por uma falta de interesse tanto pelo estudo quanto pela oferta de ensino de espanhol (cf. FERNÁNDEZ, 2000, p. 60). A esta, relacionamos dois fatores. O primeiro, analisado no item 2 do Capítulo 1, com base na 
pesquisa de Rodrigues (2010), refere-se ao apagamento e à indeterminação linguística, operados com relação às línguas estrangeiras nas LDBs de 1961, 1971, 1976 e 1996, cujo resultado foi a determinação discursiva do estudo do inglês nas escolas e a exclusão do estudo de outras línguas que antes compunham a grade curricular escolar, como o francês e o espanhol, por exemplo. Já o segundo, analisado no Capítulo 2, a partir da introdução de alguns instrumentos linguísticos de LE publicados entre os anos 30 e 80 e que selecionamos com base em sua relevância para o ensino dessa língua no contexto escolar, refere-se ao sentido de "facilidade" vinculado, primeiramente à língua espanhola e, depois, às práticas de ensino da mesma e ao efeito de "informalidade" antecipado com relação ao estudo dessa língua.

Deslocando essa análise para uma perspectiva teórica, inferimos que, tanto a partir do discurso dos documentos jurídicos quanto dos instrumentos linguísticos que selecionamos, determinados sentidos fizeram parte de um processo de regularização (cf. ACHARD, apud PÊCHEUX, 1999, p. 52) na memória discursiva sobre a LE. Vinculamos tais sentidos regularizados - ao conceito de formação discursiva (FD) que - como já dissemos ao concluir o capítulo 2 - corresponde, segundo Pêcheux (1988, p. 160), a um domínio de saber, constituído de enunciados discursivos, que representam um modo de relacionar-se com a ideologia vigente, regulando o que pode e deve ser dito.”. Assim, entendemos que os sentidos por nós identificados como regularizados na memória discursiva sobre a LE no Brasil - a saber "facilidade",228 e "informalidade" com relação ao ensino-aprendizagem dessa língua foram os que passaram a ser projetados nos enunciados que pensamos que se inscrevem "no domínio de saber" - na formação discursiva - que interpretamos no desfecho do capítulo 2. Essa "facilidade", aliás, se vincula à contradição (interpretada no Capítulo 2) que instalava a dicotomia "semelhança", "facilidade" / "diferença", "dificuldade" que consideramos marcar a

${ }^{228}$ A esse respeito, Celada (2002), inferiu, em sua pesquisa, que não foi suposto, à LE, um saber pelo qual valesse a pena submeter-se ao trabalho de estudá-la. 
relação do brasileiro com a LE, e que vimos como funcionava em relação a seu ensinoaprendizagem e como entrava no espaço escolar.

Em suma e ante todo o exposto, sintetizamos que, ao longo deste subitem 2.1.2., objetivamos colocar as interpretações que formulamos sobre o título e as capas da primeira edição de $E S F$ em relações de sentido com algumas sequências discursivas que recortamos da apresentação dessa mesma edição e, também, com as condições de produção da LE no Brasil, que analisamos na primeira parte desta dissertação. Com base nesse movimento e nas reflexões que a partir dele formulamos, finalizamos esse subitem, porém em condições de determinar mais um especificador que identificamos para o predicado sin fronteras do título, que seria: para las prácticas de enseñanza y aprendizaje de LE.

\subsubsection{Rumo à segunda edição}

A partir do percurso analítico que desenvolvemos até o final deste subitem 2.1., referente à primeira edição da coleção $E S F$, podemos apresentar algumas considerações que orientarão a passagem à segunda edição.

A série de aspectos abordados em nossas análises nos faz retomar a ideia que sinalizamos ao final do item 1 deste capítulo: a de que, de nossa perspectiva, o título Español sin fronteras funciona como indício de uma tomada de posição - por parte de uma autoria em relação ao estatuto dessa língua no Brasil e, mais especificamente, a seu ensinoaprendizagem. De fato, a partir das relações que estabelecemos com esse título, ponderamos que o que dá "corpo" a essa tomada de posição é uma série de projeções imaginárias que orientam o dizer da primeira edição dessa coleção no sentido de ligar a língua espanhola, em primeiro lugar, a um novo horizonte: o de língua que daria acesso a uma série de deslocamentos geográfico pelo mundo; e, em segundo lugar, de colocá-la em relações de 
sentido com o estatuto de uma língua capaz de despertar interesse prometendo dar conta da heterogeneidade linguística, dar acesso ao conhecimento de culturas diversas e mediante materiais adequados aos estudantes brasileiros. De fato, quando trabalhamos com a dupla determinação que operava no título da coleção, Español sin fronteras, apostamos a relação com discursividades da globalização, e com o tom eufórico que esse enunciado implica, chegando a funcionar como uma promessa. Ou seja, uma língua à qual se atribuem "razões" pelas quais valha a pena, para o brasileiro, o esforço de submeter-se a seu estudo (cf. CELADA, 2002, p. 33).

Assim sendo, nessa primeira edição, publicada em 1996, identificamos uma série de aspectos que vinculamos a uma tomada de posição (a que se materializava no título da coleção) que projeta novos sentidos para a LE com base em um "gesto de interpretação" que produz uma tensão no interior da FD a que já fizemos referência. Ao longo das análises das outras duas reedições e, fundamentalmente, no Capítulo 4, será possível identificar e definir sob qual forma, ou modalidade (cf. PÊCHEUX, 1988, apud INDURSKY, 2008), essa tomada de posição se manifesta no discurso dessa coleção e verificar se a tensão, aqui desencadeada e por nós detectada, culminará, ou não, em uma ruptura em relação à FD que se regularizou sobre a LE no espaço de enunciação brasileiro e em cuja base funciona a dicotomia "semelhança", "facilidade" / "diferença", "dificuldade".

\subsection{Segunda edição: Estudar espanhol por quêe? / Porque é uma língua de acesso à cultura de "mundos que nos hermanan"}

Assim como procedemos no subitem anterior, daremos início à análise do título Español sin fronteras, vinculando-o, primeiramente, às capas e, em um segundo momento, a alguns recortes da apresentação, ambas da segunda edição dessa coleção. 


\subsubsection{A relação com as capas}

Com relação às capas de $E S F 2^{\mathrm{a}}$ edição ${ }^{229}$, observamos que cada uma delas apresenta um design gráfico organizado sempre por dois planos cujas imagens remontam a algum país hispanofalante. O primeiro desses planos está representado por imagens vinculadas a monumentos ou lugares que são, simbolicamente, importantes do ponto de vista cultural ou histórico; e o segundo, que corresponde a uma espécie de "plano de fundo", no qual se apresentam telas de pintores de diferentes países hispanofalantes. Assim, temos no volume 1, uma escultura com fundo de uma obra do pintor uruguaio Joaquín Torres García; no volume 2, a Plaza de España em Sevilha, com fundo de uma obra de arte do pintor espanhol Salvador Dalí; no volume 3, o Parque Güell, em Barcelona, com fundo de obra do pintor espanhol Joán Miró; e no volume 4, o bairro La Boca, em Buenos Aires, Argentina, com fundo de uma obra do pintor cubano Wilfredo Lam ${ }^{230}$.

Ante essas observações, consideramos válido retomar que, ao analisar as capas da primeira edição de $E S F$, identificamos sentidos que nos permitiram determinar alguns especificadores para o predicado sin fronteras, do título. Dentre eles, os dois primeiros relacionam-se a não existência de fronteras geográficas e lingüísticas, respectivamente. A esse respeito, notamos que, nas capas da segunda edição, os sentidos seguem essa mesma direção. Ou seja, essas capas remetem a diferentes países hispanofalantes - Uruguai, Espanha, Argentina e Cuba - o que, de nossa perspectiva, (re)projeta o sentido da possibilidade de deslocamento geográfico e metafórico - este por meio da aprendizagem da LE - entre as fronteiras territoriais dos mesmos. Ademais, essa observação nos permite identificar que se (re)projeta, também, um dos sentidos em relação ao especificador linguísticas observado nas

\footnotetext{
${ }^{229}$ As capas dos quatro volumes da segunda edição estão disponíveis no anexo J.

${ }^{230}$ As informações referentes aos créditos das imagens das capas desta segunda edição foram obtidas com o editor de artes de didáticos da abril educação, Didier Dias de Moraes, por meio de contato via e-mail. (Informação pessoal recebida de didier.moraes@abrileducacao.com.br em 9. abr. 2012.)
} 
capas da primeira edição: o de ilusão de que essa coleção didática trabalhará a LE considerando suas variantes regionais, ou, ao menos, as variantes predominantes em diferentes países hispanofalantes.

Ainda no que concerne aos sentidos que identificamos e vinculamos ao predicado sin fronteras, com base nas capas da primeira edição, é válido apresentar algumas considerações que formulamos a respeito do especificador culturales, porém agora a partir das capas da segunda edição. Com relação a esse especificador, entendemos que há um movimento de entrecruzamento entre arte e história (ou história da cultura), projetado a partir do design gráfico constituído pelos dois planos que acabamos de detalhar, o qual nos sinaliza um indício de deslocamento na posição-autor. Dito de outra maneira, entendemos que tal movimento estimula o leitor, ou o público de modo geral (cf. GENETTE, 2009) que visualiza essas capas, a pensar ou a estabelecer relações de sentido entre saberes das referidas áreas de conhecimento.

De acordo com essa interpretação, ponderamos que, na segunda edição, o predicado sin fronteras, ao ser colocado em relação de sentidos com as capas dos quatro volumes da coleção, também pode ser determinado pelo sentido de culturales. Porém, diferentemente do observado e interpretado na primeira edição, não identificamos, nas capas desta segunda edição, o efeito de fragmentação que reduz o aspecto cultural a um amontoado de informações dispersas (cf. DE NARDI, 2010). Dito de outra maneira, de nossa perspectiva, o leitor não é colocado no lugar de um "espectador atônito" (cf. BOSI, 2000, apud DE NARDI ${ }^{231}$ ), mas interpelado a decifrar a relação entre as imagens superpostas e, para tanto, a interpretar ao que essas imagens se referem, o que elas representam, a quem corresponde sua autoria, etc. Ademais, outra diferença que notamos com respeito às capas da primeira edição, é a de que não identificamos, nas da segunda, imagens que enfatizem o pitoresco, o folclórico ou o

${ }^{231}$ Ibidem. 
estereotipado. A esse respeito, ponderamos que, mesmo considerando que a imagem do bairro argentino La Boca, na capa do quarto volume, possa remeter ao efeito de pitoresco, folclórico ou estereotipado - em especial, para o brasileiro - entendemos que, ao se propor uma relação entre essa imagem e a obra do cubano Wilfredo Lam, esse efeito é, de certa forma, modalizado.

\subsubsection{A relação com a apresentação}

Dando continuidade ao que expusemos no subitem anterior sobre o especificador culturales, projetado em relação ao predicado sin fronteras do título, a partir das capas da segunda edição, mobilizaremos algumas sequências da apresentação dessa mesma edição que nos ajudarão a aprofundar nossas reflexões e interpretações. A primeira delas é a que apresentamos a seguir ${ }^{232}$ :

Sd2 ${ }^{\mathbf{a}}$ _a: Aprender una lengua es abrir una puerta y descubrir muchos mundos mundos sin fronteras, que nos hermanan y nos enriquecen con su diversidad cultural. (JIMÉNEZ GARCÍA, M. L. A,; SANCHEZ HERNÁNDEZ, J., 2002 , p. 4 , grifos nossos). ${ }^{233}$

Nesta sequência, identificamos que o adjetivo cultural aparece, desta vez, na própria materialidade linguística. E, ao analisar sintaticamente o fragmento que destacamos na $\mathrm{Sd} 2^{\mathrm{a}} \_\mathrm{a}$, podemos perceber como ele entra em relação com o sintagma "mundos sin fronteras", não o especificando diretamente, mas projetando-lhe sentidos. De fato, o adjetivo “cultural” funciona como um complemento do verbo "enriquecen” e este verbo, por sua vez, apresenta como sujeito gramatical o pronome relativo "que" - "que nos enriquecen" - cuja função retoma "mundos sin fronteras".

A partir desse sintagma e de outros aspectos que aqui fomos observando, nesta

\footnotetext{
${ }^{232}$ A apresentação da segunda edição de ESF está no anexo I desta dissertação.

${ }^{233}$ Temos consciência de que um aspecto que poderia ser abordado em nossa análise é o fato de que as apresentações desta edição e da terceira foram escritas em espanhol e não em português, como foi o caso da primeira. Porém, decidimos focar nosso objetivo de analisar os sentidos projetados sobre a LE.
} 
segunda edição de $E S F$, interpretamos que os sentidos projetados, tanto a partir de suas capas quanto de sua apresentação, antecipam um leitor (cf. GENETTE, 2009) que não observa a cultura (que, como exploraremos a seguir, está mais vinculada aos países hispanofalantes da América) apenas como um espectador atônito (cf. BOSI, 2000, apud DE NARDI, 2010). De nossa perspectiva, esses dois elementos paratextuais que estamos abordando e relacionando, as capas e recortes da apresentação, projetam sentidos de aproximação à cultura por meio de alguns movimentos que sinalizam uma direção diferente à observada na primeira edição. Referimo-nos aos movimentos que identificamos em nossa análise, a saber: o gesto que interpela um leitor no sentido de que estabeleça relações entre saberes: da arte e da história (cultural); de que decifre elementos ou características relacionadas a uma obra de arte, à importância simbólica do ponto de vista histórico e/ou cultural de um determinado lugar ou monumento e, ainda, de se enriquecer a partir da diversidade cultural.

Ainda explorando a $S d 2^{a} \_a$, observamos que a primeira parte dessa sequência - a saber, "Aprender una lengua es abrir una puerta y descubrir muchos mundos" - é retomada da apresentação da primeira edição ${ }^{234}$, porém complementada por um outro enunciado que funciona como especificador para o sintagma "mundos": "mundos sin fronteras, que nos hermanan y nos enriquecen con su diversidad cultural”. Notamos, nesse enunciado especificador, o sintagma sin fronteras, no qual ressoa o título da coleção. Este sintagma aparece, aqui, em relação direta (mediante a articulação dada por uma vírgula) com uma relativa que especifica os sentidos de acordo com os quais deve ser compreendido "mundos sin fronteras", traçando, assim, a orientação do dizer: esses mundos passam a estar sin fronteras para uma aproximação entre "irmãos" (entendida a partir do enunciado em espanhol que nos hermanan) e para o enriquecimento a partir da diversidade cultural. Ante essa observação, consideramos produtivo explorar os dois termos dessa coordenação.

\footnotetext{
${ }^{234}$ Esclarecemos que esse enunciado, "Aprender una lengua es abrir una puerta y descubrir muchos mundos", ainda não foi mobilizado em nossas análises. O mesmo será analisado em relação com a apresentação da segunda edição por ser retomado e vinculado a um outro enunciado.
} 
Com relação ao primeiro - “[mundos] que nos hermanan” - consideramos importante recuperar, a partir do interdiscurso, que o sentido de "irmandade" circula em diferentes discursividades que assim caracterizam o laço ou a relação existente entre as nações latinoamericanas devido ao fato de terem sido colonizadas por países de uma mesma origem: ibérica, especificamente pela Espanha e por Portugal (cf. RODRIGUES, 2010, p. 244-246) ${ }^{235}$. Por essa relação entre o termos "hermanan" e sua determinação discursiva, podemos formular duas inferências. Para facilitar o acompanhamento de tais interpretações retomaremos $\mathrm{Sd} 2^{\mathrm{a}} \_\mathrm{a}:$

Sd2 ${ }^{\mathbf{a}}$ a: Aprender una lengua es abrir una puerta y descubrir muchos mundos mundos sin fronteras, que nos hermanan y nos enriquecen con su diversidad cultural. (JIMÉNEZ GARCÍA, M. L. A,; SANCHEZ HERNÁNDEZ, J., 2002, p. 4, grifos nossos)

A primeira dessas inferências é que, embora haja, na primeira parte $S d 2^{a} \_a$, uma indeterminação em relação à língua que se aprenderá nessa coleção devido ao uso do artigo indefinido "una" ("lengua"), a mesma é determinada pela relativa "mundos que nos hermanan" e que remete à língua falada nos países considerados “irmãos” do Brasil por esse vínculo da colonização ao qual nos referimos, ou seja, à língua espanhola. E, a segunda é que, ao termo "mundos", podemos vincular os países onde se fala a língua espanhola; e dentre estes é possível especificar, com base no sintagma “que nos hermanan” que, nessa segunda edição da coleção $E S F$, o foco será sob aqueles que estão em relação de "irmandade" com o Brasil, ou seja, os países hispanofalantes da América.

Ante as reflexões que formulamos a partir da $\mathrm{Sd} 2^{\mathrm{a}} \_\mathrm{a}$, podemos considerar que um especificador pertinente para determinar o predicado sin fronteras do título da coleção ESF, nesta segunda edição, seria políticas. Pelas análises da referida sequência discursiva da

\footnotetext{
${ }^{235}$ Rodrigues trabalha em sua pesquisa os sentidos projetados a partir do termo "co-irmãs", que aparece em alguns Projetos de Lei que analisa, como determinante da relação entre as nações americanas que foram colonizadas pela Espanha e por Portugal. A pesquisadora interpreta esse determinante como uma ressonância de sentidos dos laços de "irmandade" projetados entre esses dois países da península Ibérica. Na análise do corpus que recorta, ela detecta a forte recorrência desse termo nos projetos de lei que argumentavam a favor de que o espanhol fosse língua de ensino na escola bem como em outras textualidades, nas quais se aborda a questão da relação do Brasil com os países de fala espanhola.
} 
apresentação, identificamos sentidos que projetam "uma não existência de fronteiras políticas" entre o Brasil e os países hispano-americanos.

Para fundamentarmos a pertinência do referido especificador, observamos, também, aspectos relacionados ao intradiscurso, ou seja, aos elementos que correspondem ao mesmo eixo de formulação da apresentação da segunda edição. O primeiro deles é uma citação do escritor e jornalista uruguaio Eduardo Galeno, que faz parte do terceiro parágrafo da apresentação desta edição: Somos lo que hacemos, pero somos, principalmente, lo que hacemos para cambiar ló que somos. Ademais, outro elemento que reforça nossa interpretação é o fragmento de uma canção, localizado ao lado esquerdo da página, que retoma o termo "hermanos" presente na $\mathrm{Sd} 2^{\mathrm{a}}$ _a. Aliás, notamos que, do ponto de vista da diagramação da página de apresentação, o texto desta é colocado ao lado do referido fragmento da canção, o que nos permite pensar que se projeta uma relação dialógica entre ambos.

Esse fragmento refere-se à canção Los hermanos, de Atahualpa Yupanqui, um compositor, cantor e escritor argentino que se consagrou por ser um dos principais divulgadores da música popular desse país ${ }^{236}$. Apresentamos o referido fragmento, a seguir:

Sd2 ${ }^{\mathbf{a}}$ b: Yo tengo hermanos / Que no los puedo contar / En el Valle, la montaña, / En la pampa y en el mar. / Cada cual con sus trabajos/Con sus sueños cada cual/Con la esperanza adelante, / Con los recuerdos detrás. /Yo tengo tantos hermanos / Que no los puedo contar. (Atahualpa Yupanqui, Los hermanos. apud JIMÉNEZ GARCÍA, M. L. A,; SANCHEZ HERNÁNDEZ, J., 2002, p. $3)^{237}$

Para entender a relação que interpretamos entre o fragmento dessa canção e a $S d 2^{a} \_a$ da apresentação, é válido considerar que Los hermanos foi uma canção lançada no disco titulado “La nadita”, em 1971 e remeter a aspectos históricos desse período cujos sentidos ressoam

\footnotetext{
236 Informações obtidas no site da Fundación Atahualpa Yupanqui (Disponível em: $<$ www.atahualpayupanqui.org.ar> Acesso em 11 fev. 2011).

237 A letra da canção "Los hermanos", de Atahualpa Yupanqui, está disponível em sua íntegra no anexo K deste trabalho.
} 
no fragmento desta música. Tanto a citação de Galeano quanto a da música de Atahualpa Yupanqui parecem entrar em relação com um imaginário sobre a língua espanhola, que teve um certo auge no final do século passado (décadas de 70 e 80, sobretudo) e cujos sentidos habitam a memória discursiva sobre essa língua no Brasil.

De acordo com Celada (2002, p. 87), esse período foi marcado por uma série de fatos políticos que tiveram, historicamente, um impacto sobre a relação do brasileiro com a língua espanhola, a saber: ditadura, movimentos guerrilheiros e movimentos populares como resistência ao militarismo, dentre os principais. Nesse sentido, a autora conclui que essa língua entrou em um jogo de relações, que já tinha vida a partir do sonho representado por Cuba, e ingressou numa metonímia: "língua espanhola - solidariedade latino-americana utopia de integração". A esse respeito, ela mesma acrescenta que essa metonímia alimentou a paixão dos brasileiros pelas músicas engajadas que exploravam tal utopia e que encontrou um intérprete na figura da cantora argentina Mercedes Sosa (cf. CELADA $\left.{ }^{238}\right)^{239}$. Assim, podemos inferir que a força simbólica de citar tanto um fragmento de Galeano, quanto um fragmento da canção de Atahualpa Yupanqui reforça o universo de sentidos (que ressoam, para o leitor brasileiro, pelo viés de um imaginário presente na dimensão do interdiscurso) instalado pelo significante “hermanan” da Sd2a_a.

\footnotetext{
${ }^{238}$ Ibidem.

239 A respeito do que abordamos com base na pesquisa de Celada (2002), parece-nos produtivo relacionar um fragmento da entrevista realizada com a prof ${ }^{a}$ González, no qual ela fala sobre a relação do brasileiro com a música hispano-americana no período das ditaduras militares e os sentidos que as letras das canções projetavam no imaginário coletivo:

SdG_e: Ter entrado em contato com os grandes autores, desde os mais clássicos até os poetas e, sobretudo, com o boom da literatura hispano-americana. Eu peguei quando aquilo explodiu mesmo e nós passamos a estudar García Marques, Cortázar, Onetti, enfim todos aqueles contistas e a presença do fantástico na literatura. Tudo aquilo era fascinante e era uma época de muita repressão política em que coincidiam ditaduras tanto no nosso país quanto em outros países como na Espanha, na Argentina, no Chile. Então, esse contato com a literatura fez eclodir, isto é, fez com o espanhol aparecesse como uma língua e como um lugar de protesto, de libertação e de resistência. Além disso, havia, também, o folclore latino-americano, com Mercedes Sosa, Violeta Parra, Isella e com todos aqueles cantores e cantautores ou compositores que faziam aquelas músicas que, de alguma forma, falavam de reação, de libertação, do desejo de se libertar desses regimes de força. E tudo isso a gente fazia meio na marginalidade, porque éramos extremamente vigiados, vivíamos uma época de muita repressão. (linhas 191-203 - grifos nossos)
} 
Ante as reflexões que expusemos, podemos retomar nossa interpretação a respeito de que o fragmento "que nos hermanan" remete ao sentido de não existência de fronteiras políticas para o (termo) mundos, porém a partir de um movimento de regionalização. De nosso ponto de vista, a relação que estabelecemos entre a $\mathrm{Sd}_{2}{ }^{\mathrm{a}}$ a e a análise que desenvolvemos da $\mathrm{Sd}_{2}{ }^{\mathrm{a}}$ b - ou seja, do fragmento da canção Los Hermanos e de suas condições de produção - sinaliza-nos um sujeito do discurso identificado com uma posiçãosujeito que projeta o sentido de mundo a partir de um olhar direcionado, especificamente, para a América Latina, isto é, para "o mundo latino-americano". E, tal projeção é efeito da identificação do brasileiro com o imaginário de "utopia de integração", ao qual se refere Celada (2002) e que conseguimos recuperar a partir do fragmento da canção de Atahualpa Yupanqui e da citação de Eduardo Galeano. Ou seja, o fragmento “mundos sin fronteras que nos hermanan”, da $\mathrm{Sd} 2^{\mathrm{a}}$ _a, está, conforme nossas interpretações, vinculado ao sentido de uma integração política, de caráter regional ou, mais precisamente, subcontinental, uma vez que envolveria, especificamente, os países hispanofalantes da América.

Considerando essa interpretação a partir da Análise do Discurso, podemos perceber nesse imaginário de "utopia de integração" entre o Brasil e os países da América Latina a ressonância do real, isto é, da história. Referimo-nos ao que o sociólogo e geógrafo Magnoli (1997, p. 44) considera um dos fenômenos mais marcantes do pós-Guerra Fria: a multiplicação de acordos e blocos econômicos regionais. A esse respeito, o autor explica que, no período pós-Guerra Fria, "a antiga paisagem plana, onde se destacava o cume praticamente solitário da Comunidade Europeia, foi preenchida por cordilheiras, montanhas e morros de blocos poderosos", dentre os quais destaca o Nafta, a Bacia do Pacífico e, em outra escala, o Mercosul, o Pacto Andino, o Mercado Comum Centro-Americano e muitos outros ainda menos significativos. Assim sendo, é possível entender, de nossa perspectiva, o imaginário de "utopia de integração" mais vinculado a sentidos de uma regionalização, que identificamos na 
$\mathrm{Sd} 2^{\mathrm{a}}$ _a e na $\mathrm{Sd} 2^{\mathrm{a}} \_$b, a partir de sua relação com essa tendência histórica que fazia parte das condições de produção em que a segunda edição da coleção $E S F$ foi reeditada e (re)publicada. A essas percepções podemos associar, ainda, outras condições de produção referentes às circunstâncias da segunda edição dessa coleção. Segundo as pesquisas que Rodrigues (2010, p. 270) apresenta de Peña ${ }^{240}$ (2007, p. 32-33), verificava-se uma crise do Mercosul, desde 1999, três anos antes da publicação dessa segunda edição.

Ante os aspectos históricos que apresentamos como parte das condições de produção da segunda edição de $E S F$, podemos concluir que o sentido de aproximação, de estreitamento das fronteiras políticas entre o Brasil e os países hispano-americanos, projetados nas sequências que recortamos da apresentação dessa coleção, nos sinalizam um sujeito do discurso que se identifica com os sentidos de integração como forma de, por um lado, preservar o imaginários de "utopia" projetado para a língua espanhola pelo brasileiro (cf. CELADA, 2002) e, por outro, de resgatar a força e a representatividade que o Mercosul apresentara antes do ano de 1999. (cf. PEÑA ${ }^{241}$, apud RODRIGUES ${ }^{242}$ ).

Até esse momento, entendemos e analisamos o predicado sin fronteras do título, vinculado ao sentido de integração política, por meio da relação que estabelecemos entre este e as sequências discursivas que recortamos da apresentação da segunda edição. No entanto, além dessa relação intradiscursiva, isto é, entre dizeres enunciados em um mesmo eixo discursivo e nas mesmas condições de produção, consideramos válido, também, abordar a dimensão do interdiscurso, isto é, de dizeres já ditos - e esquecidos - em uma estratificação de enunciados que, em seu conjunto, representa o dizível (cf. COURTINE, $1984^{243}$ apud

\footnotetext{
${ }^{240}$ PEÑA, (2007). Los grandes objetivos del Mercosur: zona libre de comercio, unión aduanera y mercado común. In: BARBOSA, R. A. (Org.). Mercosul quinze anos. São Paulo: Fundação Memorial da América Latina/Imprensa Oficial do Estado de São Paulo, p. 13-43.

241 Ibidem.

242 Ibidem.

${ }^{243}$ A obra de Courtine, na qual Orlandi se baseia, para definir e diferenciar interdiscurso e intradiscurso é: COURTINE, J. J. (1984). Définition d' Orientations Théoriques et Méthodologiques en Analyse de Discours, In: Philosophiques, vol. IX, n. 2, Paris.
} 
ORLANDI, 2007a, p. 33).

A esse respeito, e para finalizar nossas análises referentes à segunda edição de $E S F$, retomaremos os dizeres relacionados ao mito da "Ilha-Brasil" (cf. RODRIGUES, 2010, p. 276-278) e os sentidos que a ele se vinculam, os quais já abordamos no Capítulo 2. Assim, identificamos a ressonância desse mito, por meio da marca da negação no sintagma sin fronteras que, na $\mathrm{Sd} 2^{\mathrm{a}} \_$a, predica o termo mundos e que, por sua vez, é especificado por sentidos que nos levaram a detectar uma especificação em relação aos países hispanofalantes da América. A negação, conforme já abordamos, pode ser identificada a partir da transformação metodológica do enunciado em uma afirmação (cf. INDURSKY, 1997, p. 217). No caso do fragmento que analisamos da $S d 2^{a} \_a$, teríamos mundos 'con fronteras' que nos hermanan. Por meio dessa transformação em uma afirmação, conseguimos reconhecer a fronteira entre formações-discursivas que, segundo Indursky ${ }^{244}$, determinam o que deve ser dito: que os diferentes "mundos" da América Latina deveriam se integrar; e o que deve ser apagado: todos os sentidos de "Ilha-Brasil" que circulam na dimensão do interdiscurso e que favoreceram um isolamento desse país no continente latino-americano. Ao referir-nos a "todos os sentidos", remetemos, com base nas pesquisas de Rodrigues (2010, p. 276-283), àqueles projetados desde o período colonial de que esse país funcionava como uma ilha, pois já possuía unidade territorial (pré-delimitada naturalmente por rios, antes mesmo da chegada dos colonizadores), e também unidade cultural (devido à ocupação desse território pelos índios tupi-guarani e a difusão de sua cultura), e linguística (pela língua geral ); até os que ainda estão presentes na atualidade, e que se relaciona, com o isolamento linguístico desse país, como uma ilha na América Latina e/ou América do Sul, por ser o único cuja língua oficial é o português.

\footnotetext{
${ }^{244}$ Ibidem.
} 


\subsubsection{Rumo à terceira edição}

De nosso ponto de vista, as análises que formulamos ao longo deste subitem 2.2., a partir da relação do título tanto com as capas, quanto com a apresentação da segunda edição de $E S F$, nos permitem interpretar que os sentidos regularizados na memória discursiva sobre a relação entre o Brasil e os países hispanofalantes e, também, sobre a relação entre línguas faladas nesses territórios estão sendo submetidos a embates e tensões no discurso dessa coleção. Movimentos estes que, com base em nossas análises, são produzidos por "outros sentidos" aportados pela história, pela exterioridade e pelo interdiscurso que interpelam o sujeito de uma maneira diferente. A esse respeito e retomando as interpretações que desenvolvemos sobre a primeira edição, pudemos perceber que, nesta segunda, a direção determinada para os dizeres sobre a língua espanhola a filiam, fundamentalmente, ao sentido de cultura - e não retomam os da necessidade de superar as dificuldades para o ensinoaprendizagem dessa língua - e de integração com os países hispano-americanos e fortalecimento regional - não de uma subordinação destes em relação à Espanha.

Assim sendo, ponderamos que essa nova direção dos dizeres ${ }^{245}$ sobre a LE pode ser colocada em relação com a tomada de posição (PÊCHEUX, 2006, p. 57) que atribuímos ao sujeito do discurso da primeira edição, especialmente, a partir da análise do título. De fato, identificamos, nesta segunda edição, gestos de "interpretação" que não reafirmam mas, também, não desacompanham o movimento dessa tomada de posição. Aqui temos sentidos de globalização mais vinculados ao "movimento de regionalização" ou de "integrações regionais", e não tanto ao global. Isto nos permite dizer também que esses outros sentidos surgem como efeito de uma modalidade diferente sob a qual o sujeito desse discurso se

\footnotetext{
${ }^{245}$ Nessa interpretação, referimo-nos à direção do dizer a partir das reflexões de Guimarães (1998, p. 432). Esse autor formula o conceito de diretividade da enunciação e o entende que o mesmo "[...] é parte do aparato de construção de unidade; é marca do lugar do autor que funciona como se pudesse excluir outras direções para a progressão textual que não a dada pela orientação argumentativa.".
} 
identifica com a formação discursiva que o interpela.

Seguindo esse movimento analítico de relacionar o título às capas e à apresentação, passaremos, agora, a terceira e última edição de $E S F$.

\subsection{Terceira edição: Estudar espanhol por quê? / Porque é uma língua veicular no mundo da globalização.}

Neste terceiro subitem, poderemos perceber - a partir do movimento analítico, adotado ao longo deste capítulo, em que colocamos três elementos paratextuais da coleção $E S F$ em relações de sentido - que a orientação dos dizeres e, por conseguinte, dos sentidos aos quais a LE é filiada no discurso da referida coleção é submetida a deslocamentos. Passaremos, portanto, a nossa análise a fim de identificar pistas que nos sinalizem qual direção esses dizeres e sentidos seguem nesta terceira edição de ESF.

\subsubsection{A relação com as capas}

A partir da observação da materialidade não verbal das capas da terceira edição da coleção $E S F^{246}$, publicada em 2007, notamos que todas apresentam um design que está organizado também a partir de dois planos, tal como as da segunda edição: um de fundo e outro sobreposto.

No plano de fundo, são apresentadas imagens referentes a algum monumento, edifício ou escultura simbolicamente importante com relação à história, à cultura ou à arqueologia de algum país hispanofalante, a saber: volume 1: La Sagrada Familia de Gaudí, em Barcelona; volume 2: El Teatro Colón, na Argentina; volume 3: a pirâmide maia Chichen Itzá, no México e volume 4: Os Moais, esculturas de rochas vulcânicas na região da Ilha de Páscoa,

\footnotetext{
${ }^{246}$ As capas dos quatro volumes da terceira edição estão disponíveis no anexo M.
} 
no Chile. Já no plano sobreposto, observamos a imagem de cinco jovens, com características físicas diferentes, que estão abraçados e de costas para os referidos monumentos, edifícios ou esculturas, com uma expressão facial de alegria, e diríamos que, em alguns casos, até mesmo, de admiração e/ou contemplação. Ademais, a respeito dessa expressão, atentamos para a direção do olhar desses jovens e observamos que dois deles estão olhando para frente e, os outros três olham para cima. A esse respeito, notamos que é, especificamente, nesses jovens, cujos olhares estão direcionados para cima, que identificamos uma expressão que se aproxima à da admiração e/ou contemplação.

Com relação a esse design, abordaremos dois aspectos que se relacionam entre si e que nos permitirão formular algumas reflexões relevantes. O primeiro deles refere-se ao fato de que, diferentemente das capas das edições anteriores, temos nas imagens desta edição a presença de "gente", especificamente, desse grupo de cinco jovens. De nossa perspectiva, a imagem destes remete a duas interpretações: a primeira é a de que antecipam, na materialidade não verbal das capas, um dos possíveis leitores dessa coleção, no caso o(s) estudante(s) de espanhol no Brasil; e a segunda interpretação nos leva a pensar que o sentido projetado pelo título da coleção - e que fomos especificando como geográficas, linguísticas, culturais - está materializado nessas capas, posto que os jovens, entendidos como antecipação dos potenciais aprendizes, já estão em um país hispanofalante, ou seja, deslocaram-se no espaço geográfico, cruzaram as "fronteiras" territoriais, no caso as do Brasil e as de um outro país, e passam, assim, pelo processo de superar as outras fronteiras também: as linguísticas e as culturais.

À luz dessas interpretações, enfocamos um segundo aspecto no design dessas capas: a posição desses jovens associada a suas expressões faciais e, mais especificamente, às direções de seus olhares. De nossa perspectiva, o fato de "estar de costas" para o objeto que simboliza um país hispanofalante associado à direção do olhar desses jovens nos remete a pensar que 
estes poderiam estar observando outro elemento, localizado à frente daquele apresentado ao fundo, e que antecipamos ser alto ou de grande dimensão, visto que três dos cinco jovens olham para cima. Uma segunda interpretação - baseando-nos, fundamentalmente, nos jovens que olham para frente - seria a de que o grupo estaria posando para uma foto tipicamente de caráter turístico. Entretanto, ao refletir de maneira específica sobre o olhar direcionado para cima e colocá-lo em relação de sentidos com as análises que desenvolvemos ao longo deste capítulo, formulamos uma terceira interpretação. Entendemos que esse olhar, como se vislumbrasse um "além" ou um "horizonte" no qual não se interpõem fronteiras ${ }^{247}$, materializa um gesto que se inscreve na direção dos sentidos que identificamos, no item 1 deste capítulo, a partir da análise da dupla determinação no título da coleção $E S F$.

A partir de todo o trabalho de interpretação aqui realizado, identificamos que, nesse olhar "além" ou ao "horizonte", ressoam os sentidos de filiar a língua espanhola ao imaginário de uma língua veicular e que, no contexto da globalização, possibilitaria a seus aprendizes olhar para o mundo, participar e interagir no mesmo. Ademais, se vinculamos essa interpretação à expressão facial desses mesmos três jovens - a qual caracterizamos como de admiração e/ou contemplação - identificamos a ressonância do tom eufórico e de promessa que detectamos como projetado a partir do título Español sin fronteras e que vinculamos a discursividades da globalização. Essa série de aspectos nos permitem afirmar que a admiração e/ou contemplação dos referidos olhares se vinculariam à "materialização" da promessa do espanhol como língua "veicular” no contexto da globalização.

\subsubsection{A relação com a apresentação}

Dando continuidade ao movimento analítico seguido neste capítulo, realizaremos

\footnotetext{
${ }^{247}$ Poderíamos chegar a dizer que esse olhar materializa a expressão sin fronteras, presente no título da coleção que abordamos.
} 
alguns recortes da apresentação da terceira edição de ESF. Para tanto, apresentamos, a seguir, duas sequências:

$\mathbf{S d 3}^{\mathbf{a}} \_\mathbf{a}:[\ldots]$ No se aprende una nueva lengua sólo por el valor del idioma en sí mismo, pero ${ }^{248}$ para ampliar nuestra participación en un mundo cada vez más amplio y complejo.

Español sin fronteras, desde su primera edición, fue elaborado con este propósito: facilitar tu acceso a un universo cada vez más amplio, para poder participar en él con éxito. [...]

Sd3 ${ }^{\mathbf{a}} \_$b: [...] Si entiendes, lees, hablas y escribes en español, podrás comunicarte con casi 500 millones de personas que también hablan español. Esto significa que contarás con un gran abanico de posibilidades que te abrirán puertas y te llevarán a descubrir otras culturas, sin fronteras..." (JIMÉNEZ GARCÍA, M. L. A,; SANCHEZ HERNÁNDEZ, J. ${ }^{249}$, negrito, grifos do autor, itálico, grifos nossos)

Nessas sequências, destacamos fragmentos cujos sentidos remetem, por metonímia, às metáforas de globalização, como, por exemplo: "mundo”, "acceso a un universo cada vez más amplio", "participar [en el mundo] con êxito", "podrás comunicarte”. E, também, identificamos a apresentação de dados numéricos - 500 millones de personas -, elemento que aparece como um pré-construído sobre o qual se sustenta ${ }^{250}$ a importância de aprender essa língua, pois vale a pena o que ela promete em termos de comunicação e participação no mundo. Essa série de elementos vai na direção de significar o espanhol como uma língua veicular, no atual contexto de globalização.

Ante o exposto, inferimos que, em relação ao eixo intradiscursivo, todas as interpretações que desenvolvemos a partir da materialidade não verbal das capas da terceira edição - a saber, a presença de "gente" em um país hispanofalante como materialização do deslocamento geográfico e o olhar direcionado para cima de três dos jovens da capa e a expressão facial destes - culminam nos dizeres, isto é, na materialidade linguística da

\footnotetext{
${ }^{248}$ Aqui é válido ressaltar que há uma inadequação gramatical, pois devido à negativa que antecede essa frase, "No se aprende una nueva lengua sólo por el valor del idioma en si mismo" deveria empregar-se a conjunção adversativa "sino" em vez de "pero". No entanto, reproduzimos o excerto conforme ele aparece na apresentação da obra e antecipamos que essa "inadequação" será analisada do ponto de vista discursivo no Capítulo 4.

${ }^{249}$ Ibidem.

${ }^{250}$ Em discursividades da globalização, especialmente naquelas vinculadas ao Mercado, as línguas importam enquanto "veiculares" e, nesse sentido, vem se reforçando o atributo segundo o qual "quanto mais pessoas falam uma língua mais veicular ela seria".
} 
apresentação desta edição. $\mathrm{O}$ mesmo movimento de culminação pode ser observado com relação ao eixo do interdiscurso: a metáfora de um "mundo sem fronteiras" e a série de sentidos a ela vinculada e que identificamos e analisamos na apresentação da segunda edição de $E S F$ - tais como, intercomunicação, economia global, trabalho, tecnologia, intercâmbio, etc. (cf. IANNI, 2001) - regulares em discursividades relacionadas ao processo de globalização, ganham espessura nos dizeres da apresentação desta terceira edição de ESF.

Ainda a respeito desta apresentação, consideramos que, em sua materialidade linguística, especificamente na $\mathrm{Sd} 3^{\mathrm{a}}{ }_{-} \mathrm{c}$, afirma-se a direção de sentidos instalada pela coleção $E S F$, desde sua primeira edição:

Sd3 ${ }^{\text {a }}$ c: Español sin fronteras, desde su primera edición, fue elaborado con este propósito: facilitar tu acceso a un universo cada vez más amplio, para poder participar en él con éxito. [...]

Neste ponto, consideramos relevante observar que essa direção de sentidos não se deu de forma linear, pois a análise do título, tanto na primeira quanto na segunda edição, em que o relacionamos com o intradiscurso ${ }^{251}$ (isto é, com outros elementos paratextuais dessa coleção: capas e recortes da apresentação) e com o interdiscurso (ou seja, com outros dizeres sobre a LE e com suas condições de produção) nos conduziu a interpretações que, não necessariamente, reforçam a linearidade da direção referida nessa afirmação da $S d 3^{a}$ _c. Sendo assim, inferimos que esta nos permite realizar, a partir da análise do fio discursivo, uma consideração. De nossa perspectiva, entendemos que ao longo das três edições de ESF foram produzindo-se deslocamentos e que a maioria deles retomava sentidos que já estavam na formação discursiva na qual, como dissemos, se inscreveu a publicação desta coleção. Entretanto, a linearidade que é afirmada na apresentação da última edição não se condiz,

\footnotetext{
${ }^{251}$ Consideramos válido designar, aqui, a série de sentidos a que fazemos referência e que observamos a partir do intradiscurso dessa coleção: aprender a língua pelo prazer, ter amor pela língua (na primeira edição); LE relacionada com os países hispanofalantes da América, língua de cultura (na segunda edição); língua de cultura, aprendizagem lúdica, língua veicular (na terceira edição). Vemos que nem todos se vinculam tão claramente ao estatuto de veicular que se coloca na terceira edição. Por nossa análise, alguns deles se filiam aos sentidos já instaurados nessa FD e que elencamos em detalhe no final do Capítulo 2.
} 
necessariamente, com a direção dos sentidos que fomos detectando a partir da análise das edições anteriores.

O que entendemos é que apenas na terceira edição, sobretudo em sua apresentação, instala-se uma tensão no interior da FD que interpela o sujeito do discurso dessa coleção. ${ }^{252}$ Tensão esta que reafirma, de alguma forma, a interpretação que formulamos ao analisar o título dessa coleção: Español sin fronteras. Segundo nossa análise, esse título funcionava como um indício de que estaria operando, aí, com base em Pêcheux (cf. 2006, p. 57), uma tomada de posição. Esta significava, de nossa perspectiva, o movimento de identificação com determinados sentidos que o sujeito desse discurso estava assumindo, pela força da história e das condições de produção da LE no Brasil - que analisamos na primeira parte desta dissertação. Assim, produzia o gesto de instalar novos sentidos para essa língua no espaço de enunciação brasileiro, cuja orientação seria a de filiar a LE ao estatuto de "língua veicular". Ante essa perspectiva, ponderamos que esse título ia em direção a produzir uma tensão a respeito da contradição constitutiva que habita a formação discursiva com a qual se relaciona a LE no Brasil, retomando outros sentidos que não reafirmassem o funcionamento dessa contradição. Resta-nos analisar, portanto, se essa tensão projetada pelo título e que consideramos que se materializa, de fato, na textualidade da apresentação terceira edição culminará com a ruptura, isto é, com a "desidentificação" do sujeito do discurso dessa coleção com a formação discursiva que o interpelou ao longo das edições anteriores.

Considerando as reflexões que formulamos, passaremos ao Capítulo 4, a fim de analisar a dimensão dessa tensão na formação discursiva que interpela o sujeito do discurso da coleção $E S F$.

\footnotetext{
${ }^{252}$ Cabe observar que os sentidos que apareciam na Gramática de Nascentes e que significavam a LE como "falada por 80 milhões de pessoas no globo", e que foram retomados no Manual de Idel Becker - tal como dissemos no final de nosso Capítulo 2 - retornam na apresentação desta terceira edição, porém submetidos à ressignificação que implica o processo de globalização no final do século passado e no início deste. Inclusive, porque essa língua vem sendo significada como veicular e, portanto, filiada a sentidos - tais como número de falantes, número de países que tem essa língua como oficial, etc. - em discursividades vinculadas ao Estado da Nação espanhola.
} 


\section{Capítulo 4}

\section{“ESPAÑOL ENTRE FRONTERAS"}

[...] Todo discurso é o índice potencial de uma agitação nas filiações sóciohistóricas de identificação, na medida em que ele constitui ao mesmo tempo um efeito dessas filiações e um trabalho (mais ou menos consciente, deliberado, construído ou não, mas de todo modo atravessado pelas determinações inconscientes) de deslocamento no seu espaço [...] (PÊCHEUX, 2006, p.56, grifos nossos).

Como acabamos de observar no encerramento do Capítulo 3, com base na análise de elementos paratextuais da coleção ESF que determinamos abordar, foi possível identificar uma tensão na formação discursiva que interpela o sujeito do discurso ao longo das três edições, a partir de gestos em que há um redirecionamento dos dizeres e sentidos projetados sobre a língua espanhola e sobre a própria coleção. No entanto, tal tensão, de alguma forma é negada na textualidade da apresentação da terceira edição $\left(\operatorname{Sd} 3^{a}{ }_{-} c^{253}\right)$, como mostramos, sob a afirmação de haver uma "linearidade" na direção dada aos sentidos projetados sobre a LE como veicular e sobre a própria coleção nas três edições da mesma. Nesse sentido, percebemos uma dissonância entre as intrepretações a partir de nossa análise e o dito na materialidade textual da apresentação da terceira edição que consideramos profícua em nossa pesquisa e decidimos analisar neste capítulo.

Assim sendo, com base no conceito de discurso sobre (cf. MARIANI, 1998, p. 60 apud RODRIGUES, 2010, p. 199) ao qual relacionamos os textos de apresentação de livros didáticos, acreditamos que seria pertinente nos debruçarmos, de maneira específica, sobre essa apresentação que nos indicou a dissonância ${ }^{254}$ a que nos referimos, pois assim nos aproximaríamos do trabalho do sujeito desse discurso tão ligado, no caso, ao trabalho de

\footnotetext{
${ }^{253}$ Retomamos, aquí, a sequência mobilizada no Capítulo 3 a qual nos referimos: Español sin fronteras, desde su primera edición, fue elaborado con este propósito: facilitar tu acceso a un universo cada vez más amplio, para poder participar en él con éxito. [...]

${ }^{254}$ A partir de nosso lugar teórico, poderíamos falar de uma "falha".
} 
autoria que projeta para o leitor os sentidos sobre o objeto que lhe apresenta: a LE e a própria coleção. Para tanto, colocaremos "o foco" deste capítulo, especificamente, na materialidade linguística da apresentação da terceira edição de $E S F$ a fim de identificar marcas que nos permitam aprofundar a observação do funcionamento da "tensão" que tem lugar no interior da formação discursiva que interpela o sujeito dessa coleção e que nos foi sinalizada, no capítulo anterior, a partir de uma sequência dessa mesma textualidade. Por meio dessas marcas, consideramos que será possível explorar o trabalho implícito nesse discurso que analisamos e interpretar que grau de "agitação nas filiações sócio-históricas de identificação" - retomando o dizer de Pêcheux na epígrafe deste capítulo - é produzido no mesmo, propiciando, assim, deslocamentos.

Em outras palavras, essa análise nos permitirá identificar os efeitos da "modalidade" pela qual o sujeito do discurso da coleção ESF se identifica com a formação-discursiva na qual consideramos que se inscreveu. Interpretamos esses efeitos, que nos ajudarão a definir a modalidade (INDURSKY, 2008), entendida como produto da tomada de posição que, no Capítulo 3, observamos ter sido capaz de "redirecionar" alguns dos dizeres e sentidos sobre a LE e de projetar, ou "prometer" o "redirecionamento" de outros. Assim sendo, podemos definir o objetivo de nossa análise neste capítulo: continuar observando os efeitos dessa tomada de posição, a fim de identificar se esse "redirecionamento" ocorre a partir da identificação do sujeito desse discurso com uma "nova" FD, cujos sentidos são capazes de "ruir" a série de dizeres e sentidos que se regularizou no interior da mesma. Como viemos mostrando, desde a primeira parte desta dissertação, essa série funcionou ao redor da dicotomia fundada por Nascentes: "semelhança" e "facilidade" / "diferença" e "dificuldade" (e a rede de sentidos que implica e que definimos no final do capítulo 2) e que materializa a contradição por ele mesmo instalada. Contradição esta que, de nossa perspectiva, determinou "historicamente" a relação do brasileiro com o ensino-aprendizagem da LE. 


\section{A APRESENTAÇÃO E AS CONDIÇÕES DE PRODUÇÃo}

Perante o exposto, neste capítulo, trabalharemos sobre a apresentação da terceira edição de $E S F$, publicada em 2007, já considerando que há uma especificidade relevante nas condições de produção da mesma, que não existia no momento de publicação nem da primeira e nem da segunda edição. Referimo-nos à N. Lei 11.161, sancionada em 5 de agosto de 2005, para determinar o oferecimento do ensino de língua espanhola no Ensino Médio de todas as instituições escolares do Brasil, a qual exploramos, de maneira mais detida, no Capítulo 1 desta dissertação.

Desde nossa perspectiva analítica, antecipamos que a publicação dessa lei pode ter incidências relevantes no discurso da apresentação da terceira edição de $E S F$ que representem inflexões no modo como o sujeito do discurso se identifica com a FD que o interpela e, por consequência, nos sentidos que são projetados sobre a LE, a partir desse instrumento linguístico, no espaço da escola. Dito de outra maneira, neste item, nosso objetivo é abordar a apresentação da terceira edição de $E S F$ a fim de analisar se o encontro/confronto entre a atualidade - marcada pela referida especificidade nas condições de produção - e a memória discursiva sobre o ensino-aprendizagem da LE no Brasil será capaz de desestabilizar a série de sentidos predominante na FD na qual consideramos que essa coleção se inscreve. Sentidos estes que, como apresentamos no final do capítulo 2, funcionaram nessa memória mediante uma contradição e, assim, determinaram "historicamente" a relação do brasileiro com o ensino-aprendizagem da LE.

Quando nos referimos à lei N. 11.161 de 2005 e antecipamos que a mesma possa ter incidido no discurso de apresentação da terceira edição de ESF de modo a provocar deslocamentos nos sentidos regularizados na memória discursiva sobre a LE no Brasil, baseamo-nos nas interpretações que Rodrigues (2010) desenvolveu sobre esse documento 
jurídico em sua pesquisa. Retomando o que já expusemos no Capítulo 1, a lei N. 11.161/2005 foi considerada por essa autora ${ }^{255}$ como um acontecimento discursivo, pois suas análises permitiram-lhe detectar alterações nas rotinas de uma memória que se constituiu no arquivo jurídico sobre o ensino de línguas estrangeiras em contexto escolar no Brasil. Essas "rotinas" às quais Rodrigues (2010) se refere correspondem a um apagamento das línguas estrangeiras na materialidade discursiva da LDB de 1961 e a uma indeterminação de quais línguas estrangeiras deveriam compor as grades curriculares das escolas (projetada na LDB de 1971 e retomada na LDB de 1996), sendo que ambos contribuíram para desencadear um processo que a pesquisadora designou de "desoficialização" das línguas estrangeiras enquanto disciplinas nas escolas brasileiras (cf. RODIRGUES, 2010, p. 82-95).

À luz das análises e das interpretações de Rodrigues, pensamos que essa lei, por ter sido sancionada dois anos antes da publicação da terceira edição de $E S F$, também pudesse ter “alterado as rotinas de uma memória", porém não no arquivo jurídico, mas no arquivo dos instrumentos linguísticos de LE, que, nesta segunda parte de nosso trabalho, está representado pela coleção didática de Español sin fronteras.

\section{NA MATERIALIDADE LINGUÍSTICA: ENTRE UM 'PERO' E UM 'SINO'}

Com base nas considerações e retomadas que fizemos, partimos, então, para a análise da apresentação da terceira edição de $E S F$. O primeiro aspecto que observamos é que esta é a única apresentação em que se especifica, na materialidade linguística, o leitor antecipado como sendo o sujeito na posição de aluno que estuda a língua espanhola. Tal especificação pode ser identificada por meio do enunciado “¡Hola! Queridos alumnos,”. Nas edições anteriores, o leitor antecipado pelo sujeito do discurso da coleção $E S F$ não era especificado na

${ }^{255}$ Ibidem. p.14-15. 
materialidade das apresentações; sendo assim, é possível considerar que, como as apresentações integram tanto o exemplar do aluno quanto o do professor, ambos poderiam corresponder ao leitor antecipado pelo sujeito do discurso na primeira e na segunda edição.

Já nesta terceira edição, a apresentação é encabeçada por uma saudação ( $; H o l a !)$ e por um vocativo (Queridos alumnos). Interpretamos esse vocativo como uma forma que especifica o interlocutor de maneira direta, interpelando-o a ocupar o lugar de aluno. Nesse sentido, pensamos que se projeta aí a antecipação, por parte do sujeito do discurso, da necessidade de que o aluno, enquanto leitor e usuário dessa coleção didática, considere esse discurso antes de começar a estudar sobre a área de conhecimento a qual a mesma se destina, ou seja, a língua espanhola.

Ante tais considerações partimos para a análise do primeiro parágrafo da apresentação da terceira edição de $E S F$ :

$\mathbf{S d} 3^{\mathbf{a}} \mathbf{a}^{\mathbf{2 5 6}}$ : Cuando aprendemos un nuevo idioma, abrimos una puerta que da paso a una nueva cultura, a las particularidades de otros pueblos. No se aprende una nueva lengua sólo por el valor del idioma en sí mismo, pero para ampliar nuestra participación en un mundo cada vez más amplio y complejo. (JIMÉNEZ GARCÍA, M. L. A,; SANCHEZ HERNÁNDEZ, J, 2007, p.3, grifos nossos)

Notamos, nessa sequência discursiva o funcionamento de um processo prarafrástico, uma vez que o fragmento que a inicia - Cuando aprendemos un nuevo idioma, abrimos una puerta que da paso a una nueva cultura, a las particularidades de vida de otros pueblos - retoma, de nossa perspectva os dizeres das apresentações da primeira e da segunda edição, respectivamente: Aprender una lengua es abrir una puerta y descubrir muchos mundos. $\left(1^{\mathrm{a}}\right.$ edição); Aprender una lengua es abrir una puerta y descubrir muchos mundos - mundos sin fronteras, que nos hermanan y nos enriquecen con su diversidad. ( $2^{\mathrm{a}}$ edição). No entanto, em relação à apresentação da terceira edição de $E S F$, notamos que a este enunciado que

\footnotetext{
${ }^{256}$ Esclarecemos que ordenaremos as sequências recortadas neste capítulo com letras do alfabeto em maiúscula para diferenciá-las daquelas que já recortamos no Capítulo 3, referentes a essa mesma edição.
} 
caracterizamos como uma paráfrase, segue um outro, que representa uma negação - No se aprende una nueva lengua sólo por el valor del idioma en sí mismo, pero para ampliar nuestra participación en un mundo cada vez más amplio y complejo. - e que interpretamos sinalizar um deslocamento do efeito de sentidos projetados no fio discurso das apresentações dessa coleção. O que queremos dizer é que embora notemos uma repetição dos dizeres das apresentações das edições anteriores (a partir desse enunciado de parafrástico), entendemos que esse efeito é "deslocado" a partir da negação que o sucede.

Esse enunciado chamou nossa atenção porque, de fato, sua estrutura produz, em espanhol, um efeito de non sense. Uma abordagem mais cuidadosa nos levou a perceber que a presença do conector adversativo pero - tal como é designado nas gramáticas de espanhol para ligar os dois fragmentos que a compõem - a saber, No se aprende una nueva lengua sólo por el valor del idioma en sí mismo, e para ampliar nuestra participación en un mundo cada vez más amplio y complejo - não é o adequado e, nem sequer, é o possível considerando o funcionamento da língua espanhola: o tipo de negação que aparece no primeiro termo e a direção de sentidos que se instala entre este e o segundo demandariam a forma "sino" (que, em português, corresponde ao sintagma conjuncional "mas sim" ou, recuperando uma forma presente na memória dessa língua ${ }^{257}$ : “senão"), mas não seria pero que, na verdade, produz nesse sintagma um efeito de non-sense, como já dissemos.

Ante tal percepção, recorremos ao estudo que Erloza (2007) desenvolve sobre a evolução e o processo de gramaticalização das conjunções adversativas e encontramos que, segundo as conclusões da referida autora com base nas interpretações de Flamenco ${ }^{258}$ :

Pero y sino "no forman una oposición estrictamente sintáctica", "la diferencia entre ambas conjunciones adversativas debe buscarse ante todo en

\footnotetext{
${ }^{257}$ Cf. PAYER, 1995.

258 A obra que Erloza cita de Flamenco é: FLAMENCO GARCÍA, L. (1999), Las construcciones concesivas y adversativas., en I. Bosque y V. Demonte (dirs.), p. 3872.
} 
su diferente naturaleza semántica y pragmática"259 (ERLOZA, 2007, p. 20).

Com base nessa observação e também na vertente teórica da $\mathrm{AD}$ que adotamos nesta pesquisa, consideramos que mais relevante do que focar a inadequação sintática produzida pelo uso do pero $^{260}$, seria considerar os sentidos que o diferenciam de sino. Por meio desse movimento analítico, pensamos ser possível encontrar pistas produtivas para pensar em qual direção deveríamos interpretar esse enunciado e se essa direção produziria alguma alteração nos sentidos projetados sobre a língua espanhola na apresentação desta terceira edição em relação às apresentações das edições anteriores.

Partindo, pois, dessa consideração, retomamos os estudos que Erloza ${ }^{261}$ desenvolve para entender a diferença semântico-pragmática de tais conectores e, assim, interpretarmos o enunciado que recortamos da apresentação da terceira edição de ESF. A referida autora esclarece, com base em Flamenco ${ }^{262}$ (apud ERLOZA ${ }^{263}$ ), que pero faz parte de um importante grupo de conectores "contra-argumentativos", que compartilham a propriedade de suprimir uma das possíveis inferências que poderiam ser deduzidas com base no enunciado antecedente, marcando a orientação argumentativa em que a comunicação irá se desenvolver (ERLOZA, 2007, p.20). Erloza ${ }^{264}$ acrescenta, ainda, que, conforme Portolés ${ }^{265}$, esse aspecto contra-argumentativo do referido conector não significa que o segundo enunciado contradiga ou refute o primeiro, mas que o pero indica que será o segundo enunciado, e não o primeiro, que condicionará a continuidade do discurso - tendo, assim uma força maior. Para finalizar, a

\footnotetext{
${ }^{259}$ A tradução correspondente a essa citação seria: “'Pero' e 'sino' não estabelecem uma oposição estritamente sintática, a diferença entre ambas as conjunções adversativas deve ser buscada, primeiro, na diferente natureza semântica e pragmática das mesmas.".

${ }^{260}$ Consideramos, também, que ao analisar o processo de gramaticalização dos conectores "pero" e "sino", Erloza (2007, p.18) encontrou registros, em textos do século XIII, em que o "sino" era utilizado sem que o enunciado anterior fosse necessariamente uma negação. Esse dado fez-nos pensar que, de fato, ao se gramaticalizar, o conector adversativo "sino" passou a iniciar enunciados precedidos por uma negação, muito mais devido a aspectos "semânticos e pragmáticos" - como diria essa autora - do que sintáticos.

261 2007, p.20.

262 Ibidem, p. 3863-3864

263 Ibidem.

264 Ibidem.

265 A obra que Erloza cita de Portolés é: PORTOLÉS, J. (1998b), Marcadores del discurso, Barcelona: Ariel, p. 100.
} 
autora alude a Montolío ${ }^{266}$ que define pero como o protótipo de "expressões conectivas que introduzem o argumento 'forte', isto é, aquele que 'ganha a batalha na dialética'”.

Já com relação a sino, Erloza ${ }^{267}$ também recorre às explicações de Flamenco que esclarecem que este conector adversativo tem um valor semântico de refutação, pois:

[...] funciona como um termo de polaridade negativa, isto é, o seu funcionamento está condicionado a que na oração apareça explicitamente uma negação. Diretamente relacionado com este comportamento, está o fato de que o "sino" permite interpretar, de maneira inequívoca, qual é o foco de uma oração, ou seja, a parte da oração destacada pela entonação e que contém a informação mais relevante. O "sino" é um marcador de retificação; isto é, ao ser usado não se suprimem as inferências que poderiam ser deduzidas do enunciado anterior, mas sim se anula a verdade do dito ou do sugerido no mesmo. ${ }^{268}$

Com base em tais esclarecimentos, retomamos o segundo enunciado da apresentação da apresentação da terceira edição de $E S F$, que nos levou a focaliza o conector pero a fim de reinterpretar o que tínhamos caracterizado, a uma primeira observação, como non sense.

Pensando teoricamente, a partir da $\mathrm{AD}$, sobre esse non sense, o qual vinculamos a uma “inadequação em relação ao funcionamento da língua espanhola”, percebemos que estaríamos diante de um equívoco - aliás, altamente produtivo, como veremos, na materialidade que analisamos. De fato, entendemos que o uso de sino para ligar as orações No se aprende una nueva lengua sólo por el valor del idioma en sí mismo e para ampliar nuestra participación en un mundo cada vez más amplio y complejo atenderia ao funcionamento da LE, porém colocaria em xeque a coerência discursiva das textualidades que estudamos na coleção $E S F$. Esta, em sua trajetória de publicação - a qual analisamos no Capítulo 3 desta dissertação a

\footnotetext{
${ }^{266}$ A obra que Erloza cita de Montolío é: MONTOLÍO, E. (2001), Conectores de la lengua escrita, Barcelona: Ariel, p. 62.

${ }^{267}$ Ibid.

${ }^{268}$ A explicação de Flamenco (1999, p. 3859) que apresentamos a partir de Erloza (2007, p.20) corresponde à tradução que realizamos do seguinte fragmento em espanhol: "Sino es un conector adversativo refutativo "que funciona como un término de polaridad negativa, esto es, su funcionamiento está condicionado a que en la oración aparezca explícitamente una negación. Directamente relacionado con este comportamiento está el hecho de que permite interpretar inequívocamente cuál es el foco de una oración, a saber, la parte de la oración destacada entonativamente y que es informativamente más relevante" (FLAMENCO, 1999: 3859); es "un marcador de rectificación; esto es: al ser usado no se suprimen las inferencias que podrían deducirse del enunciado anterior, sino que simplemente se anula la verdad de lo dicho o sugerido en el mismo" (FLAMENTO, id., p.3868).
} 
partir do título, das capas e de fragmentos da apresentação em suas três edições - apresentou dizeres para o espanhol que vinculavam essa língua bem como o ensino-aprendizagem da mesma à seguinte série de sentidos: amor por essa língua, prazer em estudá-la, língua de acesso à riqueza cultural e ao mundo das ideias e de vinculação aos países hispanofalantes em especial os da América -, língua que estimula a reflexão, que propicia diversão, o acesso a modernidade e o conhecimento interior, dentre os principais. Ou seja, sentidos que remetem ao valor del idioma em sí mismo e que sino - consoante o exposto por Erloza (2007), inclusive com base em estudos de outros autores - anularia e retificaria por meio do dizer de que aprender uma língua seria estritamente ampliar nuestra participación en un mundo cada vez más amplio y complejo.

Por outro lado, o conector pero - embora não esteja em conformidade com o funcionamento da língua espanhola, produzindo, assim, um equívoco na materialidade linguística (produzida por um sujeito entre-línguas) - não projetaria uma incoerência no fio discursivo da coleção $E S F$. O que entendemos é que o pero não refutaria os sentidos projetados pelo enunciado Aprender una lengua es abrir una puerta y descubrir muchos mundos que aparece na apresentação da primeira edição de $E S F$ e que é parafraseado tanto na segunda edição quanto nesta terceira.

Com base em nossa análise, interpretamos que pero refutaria apenas uma das possíveis inferências que poderia ser deduzida a partir desse enunciado definidor, inferência esta que é explicitada na apresentação da terceira edição, ou seja, a de que se aprende uma língua sólo (somente) pelo valor que ela tem em si mesma e não por nenhum outro aspecto relacionado, por exemplo, às necessidades de um sujeito pragmático (cf. PÊCHEUX, 2006, p.33). Sendo assim, o conector pero não excluiria o sentido de que as línguas têm valores inerentes a elas mesmas mas colocaria o foco no dizer de que este é um, porém não o único nem o principal, dentre os diversos motivos, para se aprender outras línguas. A partir do estudo de Erloza 
(2007), entendemos que esse conector, apenas marca que não será mais este o sentido que condicionará ou que deverá ter uma força maior no discurso que apresenta a coleção ESF bem como o ensino-aprendizagem da LE sob a inflexão do espaço de enunciação escolar. Ou seja, o equívoco identificado na materialidade linguística devido ao uso do pero em vez do sino permite-nos inferir que o sujeito do discurso nessa coleção não se "desidentifica" (cf. INDURSKY, 2008) plenamente com a formação discursiva que o interpela desde a primeira edição a partir de dizeres que filiavam a LE, bem como seu ensino-aprendizagem a sentidos de um estudo lúdico e prazeroso, de uma língua pela qual se sentiria amor, seria possível ter acesso à cultura, à diversidade, à reflexão. etc., porém acrescenta a essa FD sentidos que vinculam o espanhol e seu ensino-aprendizagem submetido às inflexões do espaço escolar também às urgências pragmáticas com relação ao sujeito contemporâneo. E é, aí, que de nossa perspectiva, justamente, se instala uma tensão, isto é, entre os sentidos que seguem na direção a significar essa língua como veicular e toda a série dicotômica e paradoxal de sentidos que predominou na formação discursiva sobre a LE e que já abordamos neste trabalho, fundamentalmente no Capítulo 2.

Ante a análise que desenvolvemos em relação ao primeiro parágrafo da apresentação da terceira edição de ESF, é válido apresentarmos o segundo e o terceiro parágrafos, respectivamente, a fim de passarmos às conclusões finais deste capítulo:

$\mathbf{S d}^{\mathbf{a}}{ }_{-}$b: Español sin Fronteras, desde su primera edición, fue elaborado con este propósito: facilitar tu acceso a un universo cada vez más amplio, para poder participar en él con éxito. Es una colección pensada para ti que quieres aprender el español de una forma agradable y divertida. En esta nueva edición, hemos introducido nuevas secciones con textos interesantes y llenos de curiosidades, hemos elaborado ejercicios más contextualizados, hemos buscado, en fin, ofrecerte un curso más moderno y atractivo, fundamentado en un abordaje comunicativo. Sin embargo, hemos buscado mantener la metodología adoptada en las ediciones anteriores, por haberse revelado útil a todos los estudiantes que se han servido de ella hasta el presente momento. Pero sabemos que no basta el libro, será necesario, principalmente, tu empeño, sin el cual todo tu esfuerzo habrá sido inútil. Al fin de cuentas, tú serás el principal agente de tu aprendizaje para que puedas dominar plenamente el español. No consideres el estudio como una obligación sino como una oportunidad para entrar en el mundo del conocimiento y del 
saber.

Sd3 ${ }^{\mathbf{a}}$ _c: Si entiendes, lees, hablas y escribes en español, podrás comunicarte con casi 500 millones de personas que también hablan español. Esto significa que contarás con un gran abanico de posibilidades que te abrirán puertas y te llevarán a descubrir otras culturas, sin fronteras..." (JIMÉNEZ GARCÍA, M. L. A,; SANCHEZ HERNÁNDEZ, J, 2007, p.3, - negrito, grifos do autor, itálico, grifos nossos)

Neste momento, podemos entender a tensão que identificamos ao final do Capítulo 3, entre o enunciado afirmativo Español sin Fronteras, desde su primera edición, fue elaborado con este propósito: facilitar tu acceso a un universo cada vez más amplio, para poder participar en él con éxito., e as interpretações que desenvolvemos a partir da análise da relação entre o título, as capas e recortes das apresentações das três edições dessa coleção. Ou seja, essa tensão pode não só ser percebida a partir da análise do fio discursivo dos referidos elementos paratextuais dessa coleção ao longo de suas reedições, mas também com base no próprio intradiscurso desta terceira edição. O que queremos dizer é que, considerando a ocorrência do conector adversativo pero no enunciado que aqui enfocamos e o equívoco produzido na materialidade linguística do mesmo, pela estrutura de uma sintaxe que levaria à ocorrência de sino, é possível inferir que no discurso dos elementos paratextuais das edições anteriores há "gestos de interpretação" e de identificação com relação à formação discursiva na qual, de nossa perspectiva, se inscreveu essa coleção. E, inclusive, que essas "interpretações" e identificações que detectamos nas textualidades das edições anteriores não estão sendo completamente refutadas nesta terceira edição de $E S F$, visto que ainda permeiam os sentidos projetados na mesma. O enunciado Es una colección pensada para ti que quieres aprender el español de una forma agradable y divertida., por exemplo, alude a sentidos já filiados na memória discursiva sobre o ensino aprendizagem de LE no Brasil, conforme analisamos no Capítulo 2, e que estiveram presentes, também, nas edições anteriores de $E S F$, restabelecendo, assim, o efeito de informalidade e de "deleite" (cf. FRIGÉRIO, 1977).

Em meio a esse confronto entre a atualidade - caracterizada pela inserção da língua espanhola na grade curricular das escolas brasileiras e que neste momento entrava em relação 
de sentido com a sanção da Lei N. 11.161/2005 269 - e a memória discursiva sobre essa língua - na qual determinados dizeres e sentidos se regularizaram especialmente a partir da inflexão dessa língua ao processo de ensino-aprendizagem -, notamos, mais uma vez, como a memória se sobrepõe à atualidade. ${ }^{270}$ Ou seja, a "atualidade" (pensada aqui como metáfora das condições de produção e dos sentidos que estas instalam inclusive a partir do texto legal da Lei N. 11.161/2005) não é capaz de fazer ruir a série de sentidos preponderante na formação discursiva que se instalou no funcionamento da memória discursiva sobre o ensinoaprendizagem na LE no Brasil, especialmente no espaço de enunciação escolar. Podemos perceber esse confronto, bem como a sobreposição da memória sobre os sentidos da atualidade, a partir da materialidade linguística da apresentação da terceira edição, especificamente a partir dos enunciados finais do segundo parágrafo e dos enunciados do terceiro parágrafo, os quais retomamos a seguir:

$\mathbf{S d 3}^{\mathbf{a}}$ dd: Pero sabemos que no basta el libro, será necesario, principalmente, tu empeño, sin el cual todo tu esfuerzo habrá sido inútil. Al fin de cuentas, tú serás el principal agente de tu aprendizaje para que puedas dominar plenamente el español. No consideres el estudio como una obligación sino como una oportunidad para entrar en el mundo del conocimiento y del saber.

Sd3 ${ }^{\mathbf{a}} \_$e: Si entiendes, lees, hablas y escribes en español, podrás comunicarte con casi 500 millones de personas que también hablan español. Esto significa que contarás con un gran abanico de posibilidades que te abrirán puertas y te llevarán a descubrir otras culturas, sin fronteras..." (DE LOS ÁNGELES, MARÍA J. G.; HERNÁNDEZ, JOSEPHINE, 2007, p.3, grifos nossos)

Notamos que há dizeres cuja direção é a de filiar o espanhol aos sentidos de empenho, de esforço e de domínio pleno dessa língua, que correspondem a algumas das antecipações imaginárias projetadas para o "estatuto disciplinar" no espaço de enunciação escolar. Porém, o enunciado subsequente - a saber, No consideres el estudio como una obligación sino como

\footnotetext{
${ }^{269}$ É válido esclarecer que temos ciência de que a referida lei obriga a oferta do ensino da língua espanhola apenas aos alunos do Ensino Médio e que estes podem optar entre cursar ou não essa disciplina. No entanto, entendemos que essa obrigatoriedade da presença da LE no espaço de enunciação escolar, ainda que apenas no nível de Ensino Médio, legitima essa língua, ou pelo menos deveria legitimá-la, nesse espaço de modo geral caso a mesma seja ofertada ou inserida como disciplina na grade curricular de outros níveis de ensino, como o Ensino Fundamental, por exemplo, ao qual se destina a coleção ESF que estamos analisando.

${ }^{270}$ Esclarecemos que a confronto entre atualidade e memória está sendo explorado e trabalhado em nossa dissertação com base nas interpretações de Celada (2002).
} 
una oportunidad para entrar en el mundo del conocimiento y del saber - atenta para o fato de que o estudo não deve ser considerado como uma obrigação ${ }^{271}$, mas sim como uma oportunidade para entrar no mundo do conhecimento e do saber. É válido notar que neste enunciado, que também se configura como um período composto cuja oração principal é uma negação, o conector adversativo utilizado para ligá-la a segunda oração é o sino e não o pero. Sendo assim, como já expusemos, podemos interpretar, pelo viés discursivo, que sino anula qualquer dizer que pudesse tentar vincular a língua espanhola, uma vez inserida na grade curricular da instituição de ensino adotante da coleção $E S F$, a um dos principais sentidos antecipados para o "estatuto disciplinar": a obrigação ou o comprometimento em estudar a área de conhecimento representada por uma disciplina.

\section{No REAL: "ESPAÑOL" ENTRE O "ESTAR OU O NÃO ESTAR" FILIADO AO ESTATUTO DISCIPLINAR, "EIS A QUESTÃO!”}

Com respeito às análises que realizamos neste capítulo, consideramos que as mesmas se nortearam, de modo fundamental, pela percepção de marcas linguísticas na materialidade do texto de apresentação da terceira edição de $E S F$, especificamente em relação aos “conectores" pero e sino e à alternância na ocorrência dos mesmos. Essas marcas linguísticas foram por nós interpretadas discursivamente, considerando não a oposição sintática entre os referidos conectores, mas a oposição semântico-pragmático entre os mesmos e os sentidos que esta oposição projeta em nível discursivo. Dessa maneira, tais sentidos sinalizam-nos a relação do sujeito do discurso a respeito da FD na qual se inscreve.

Ante tais análises, podemos considerar que o sujeito do discurso dessa coleção,

\footnotetext{
${ }^{271}$ Esclarecemos que, embora a materialidade linguística não especifique que é o estudo de espanhol que não deve ser considerado uma obrigação, é possível considerar que essa língua está, implicitamente, vinculada a não obrigatoriedade de estudo a partir do intradiscurso, ou seja, dos enunciados imediatamente anteriores ao que estamos analisando.
} 
especificamente no discurso de apresentação dessa terceira edição, continua interpelado pelo funcionamento da contradição (que vinculamos à dicotomia instalada por Nascentes: "semelhança"e "facilidade" / "diferença" e "dificuldade", e a série de sentidos com a qual ela entra em relação) que, como mostramos, desde a primeira parte desta dissertação, determinou a relação do brasileiro com a LE. Na apresentação da terceira edição essa contradição aparece materializada na textualidade a partir do conector adversativo pero (e a fricção que se produz aí pela presença/ausência de sino.) Ou seja, o sujeito do discurso dessa coleção ocupa uma oposição que caracterizamos como "entremeio" - entre o "refutar" ou negar os sentidos da memória discursiva sobre o ensino-aprendizagem da LE no Brasil e assim substituí-los por outros, tendendo, assim, a uma "desidentificação" (cf. INDURSKY, 2008) e provocando uma ruptura com a formação discursiva que o interpela(va) - tudo o que simultaneamente implicaria a identificação com uma FD diferente -; ou continuar identificando-se com essa mesma FD e acrescentar-lhe sentidos novos, na tentativa de que estes consigam se sobrepor àqueles e "ganhar a batalha na dialética", assim como faz o conector "pero" (cf. MONTOLÍO ${ }^{272}$ apud ERLOZA, 2007, p.20). Neste caso, não há uma ruptura, há apenas uma tensão, confirmando o que observamos no final do Capítulo 3 e que retomamos no presente capítulo.

Sendo assim, ao ocupar essa posição de "entremeio", podemos inferir que aquela "tomada de posição" que interpretamos ao abordar o título da coleção ESF não mobiliza um acontecimento discursivo, tal como o entende Pêcheux (2006) mas um acontecimento enunciativo, conforme propõe Indursky (2008), que criou uma tensão na FD e, portanto, na memória discursiva sobre a LE no Brasil. Neste caso, poderíamos acrescentar, a nova série de sentidos não consegue fazer ruir a antiga (cf. ACHARD, p. 23, 1999) a já instalada e cristalizada em certas rotinas.

\footnotetext{
${ }^{272}$ A obra que Erloza cita de Montolío é: MONTOLÍO, E. (2001), Conectores de la lengua escrita, Barcelona: Ariel, p.62.
} 
Ao formular essas reflexões, inferimos que a língua espanhola também pode ser interpretada como ocupando uma posição de "entremeio" no espaço de enunciação escolar. Nesse caso, o que entendemos é que, na materialidade linguística da apresentação da terceira edição de $E S F$, a memória discursiva do espanhol parece estar entre um pero e um sino. Porém, a análise discursiva dos sentidos projetados pela já mencionada fricção entre tais conectores permitem-nos pensar (retomando a questão que nos colocamos na Introdução deste trabalho) que, no real do espaço de enunciação escolar, o lugar ocupado por essa língua está entre o "disciplinar" e o "não-disciplinar". Ou seja, entre "estar ou não estar, (eis a questão)" 273; filiada aos sentidos que lhe permitam ajeitar-se nas evidências e no lugar já feito que supõe o estatuto disciplinar (cf. ORLANDI, 2006, p.7), tanto para os alunos quanto para a comunidade escolar, desde que a grade curricular da instituição de ensino a apresente como tal.

Por fim, antes de apresentar uma leitura do percurso trilhado nesta dissertação em nossas considerações finais, ponderamos que perceber essa posição de "entremeio" ocupada pelo sujeito do discurso da coleção didática que focalizamos nesta segunda parte de nossa dissertação, e que se reflete no real do espaço de enunciação escolar sendo, também, a posição ocupada pela LE no mesmo, contribuiu para que possamos entender o porquê a indagação "Por que estudar espanhol, professora?" - que suscita-nos um "mal-estar" e que foi o disparador desta pesquisa, ainda ecoa com tanta frequência nas salas de aula. Ou seja, entendemos que essa indagação "desestabilizadora" para o sujeito na posição de professor, que muitas vezes, pode interpretá-la como uma resistência pessoal ou como uma crítica ou um desmerecimento à sua prática, vincula-se a aspectos que transcendem as paredes das salas de aula e das instituições de ensino. Esses aspectos, como observamos e analisamos nesta pesquisa, vinculam-se às condições de produção da LE no espaço de enunciação escolar,

\footnotetext{
${ }^{273}$ Aqui, estabelecemos uma ilação com os sentidos da famosa frase do poeta e dramaturgo inglês Wiliam Shakespeare, utilizada em uma de suas peças teatrais, Hamlet.
} 
desde a década de 20 dos anos 90 e à fundação e funcionamento de uma memória para essa língua no Brasil, cujos sentidos foram "apenas" deslocados, porém não desestabilizados no discurso produzido sobre a mesma tanto nos documentos jurídicos quanto nos instrumentos linguísticos e, assim, nenhuma dessas textualidades instaurou um acontecimento discursivo novo capaz de fazer "ruir" a indagação: Por que estudar espanhol, professora?

Perante as reflexões que desenvolvemos a partir do texto de apresentação da terceira edição de $E S F$, pudemos cumprir o objetivo o qual nos propusemos na segunda parte deste trabalho; isto é, perceber sob que modalidade se dá a tomada de posição do sujeito do discurso dessa coleção. Ao longo de nossas análises nossa hipótese era que essa modalidade correspondia, com base em Indursky (1998), a da "contra-identificação" e, mediante o enfoque da apresentação da terceira edição, pudemos encontrar um novo indício desse movimento, materializado nos sentidos instalados pelo funcionamento "conector adversativo" pero.

Em suma, ponderamos que no discurso dessa coleção didática sobre a língua espanhola, o sujeito do mesmo não foi capaz de instaurar um "sino" nos textos que apresentavam a LE nessa coleção. Ou seja, não "tomou uma posição" capaz de desatar uma "desidentificação" que fizesse ruir, ou que (pensando no funcionamento de sino) retificasse e anulasse as regularizações na formação discursiva relacionada à LE no espaço de enunciação brasileiro, especificamente, na escola. Logo, as "fronteiras" que essa FD instalou no real da escola, também continuam "erguidas" e dificultando a filiação da LE a um estatuto disciplinar, a despeito (ou justamente por causa) da Lei N. 11.161/2005, em vigência.

Destarte, passaremos às considerações finais que formulamos com base no percurso de análise dessa pesquisa. 


\section{CONSIDERAÇÕES FINAIS}

Neste ponto, pensamos que é pertinente observar que a primeira parte desta dissertação apresentou algumas considerações parciais acerca da análise que nela realizamos e, na segunda parte, o Capítulo 4 teve também certo caráter conclusivo. Por isso, neste item, pretendemos apenas terminar de enlaçar as considerações que nessas duas partes formulamos. Será necessário, antes, retomarmos nosso ponto de partida.

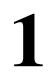

O título dado a esta dissertação - ¿“Español sin fronteras”? Ou entre as fronteiras projetadas pelo real e pelo imaginário? - foi pensado com base em uma inquietação vivenciada por nós, enquanto docentes de língua espanhola, devido aos frequentes questionamentos apresentados por grande parte de nossos alunos do ensino fundamental II sobre o porquê estudar espanhol. Começamos a analisar nossa inquietação e a perceber que a mesma estava relacionada a um confronto entre o imaginário que havíamos antecipado sobre a língua espanhola de acordo com o contexto histórico no qual estávamos inseridos - isto é, aquele que entrava em relação com uma nova série de sentidos que, na década de 90, começou a significar essa língua como veicular (cf. CELADA, 2002) e, portanto, a valorizar e incentivar seu estudo - e o real, mais especificamente, o real da escola que irrompia em meio às nossas práticas docentes, materializado mediante manifestações que interpretamos como uma resistência a estudar essa língua. Sendo assim, numa análise dessas condições de produção imediatas à nossa prática encontramos indícios de que a LE se apresentava no contexto escolar, sob um estatuto que definimos como "não-disciplinar" (cujos sentidos aqui abriremos) e que será vinculado, ainda nestas considerações, a marcas de informalidade e de não formalidade a partir das quais essa língua é apresentada na escola.

Ante tais reflexões, decidimos, então, estudar o funcionamento da memória discursiva 
sobre a LE com base na perspectiva teórica da Análise do Discurso e com especial inflexão no espaço de enunciação escolar, a fim de identificar sentidos filiados a essa língua que, no referido espaço, sustentam esse estatuto caracterizado por nós como "não-disciplinar".

\section{2}

Uma vez definido o objeto de nossa pesquisa - a análise de aspectos da constituição de uma memória discursiva sobre a LE no Brasil (ou seja, do modo de significar a LE no espaço de enunciação brasileiro) bem como do funcionamento dessa memória a partir de domínios discursivos relativos ao espaço escolar - e determinada a vertente teórica que nos orientaria a da $\mathrm{AD}$ - procedemos à realização de três recortes a fim de especificar o corpus que abordaríamos.

Para o primeiro deles foi necessário determinar qual elemento enfocaríamos dentre os diversos que fazem parte do processo de ensino-aprendizagem de uma língua estrangeira na escola. Nesse sentido, a partir de leituras e estudos já desenvolvidos sobre o ensinoaprendizagem de línguas estrangeiras em contexto escolar e, também, de nossa experiência docente, pareceu-nos pertinente escolher o livro didático, com base na função de principal mediador que o mesmo, tradicionalmente, vem desempenhando na educação brasileira (cf. SOUZA, 1999, p. 94). Sendo assim, passamos a nosso segundo recorte: o de selecionar, em meio ao campo de livros didáticos de LE em circulação no mercado editorial nacional, um LD que tivesse apresentado relevância no processo de ensino-aprendizagem de espanhol nas escolas brasileiras. Antes essa perspectiva, chegamos à coleção Español sin fronteras, utilizada desde 1996 até os dias atuais no ensino fundamental II, que é o lugar da nossa prática, e especialmente em escolas da rede particular ${ }^{274}$.

\footnotetext{
${ }^{274}$ Referimo-nos de maneira especial ao espaço da rede particular não apenas por ser esse o lugar de nossa prática docente, mas também e principalmente pelo fato de que a língua espanhola não é uma disciplina oficial no ensino fundamental II. Lembramos que, conforme a LDB/1996, deve-se oferecer a esse nível de ensino uma
} 
E, por fim, ante a definição de nosso corpus - a coleção ESF - sentimos a necessidade de realizar, ainda, um terceiro recorte a fim de especificar quais aspectos desse objeto analisaríamos. Decidimos, então, abordar as três edições dessa coleção a partir de três elementos paratextuais: o título, as capas e as apresentações.

Ao definir o corpus que mobilizaríamos para desenvolver nossa pesquisa, percebemos que o fato de analisar uma coleção didática - ESF - introduzia-nos no "campo" do arquivo dos instrumentos linguísticos. Destarte, ao especificar o objeto central do corpus abordado em nossa pesquisa - e, por conseguinte, o arquivo ao qual o mesmo se relaciona - e adotar a vertente teórica da $\mathrm{AD}$ para nossa análise, percebemos que seria necessário conhecer e interpretar aspectos das condições de produção nas quais a LE se inscreveu ao passar a habitar o espaço escolar e, especialmente, aquelas em que nosso instrumento linguístico fora publicado e utilizado no referido espaço como mediador do ensino-aprendizagem dessa língua.

Nesse sentido, à luz de definições formuladas por Pêcheux (2010, p.51) sobre o conceito de arquivo, dois aspectos apresentaram-se como relevantes para definir e organizar a estrutura de análise do corpus central desta dissertação. O primeiro deles foi o de que teríamos que mobilizar outro "campo de documentos", no caso o arquivo jurídico referente ao ensino das línguas estrangeiras na escola, de maneira especial aqueles que determinaram o ensino da LE. E, o segundo aspecto se relaciona com a percepção da necessidade de ampliar a abertura do arquivo dos instrumentos linguísticos, que já iríamos abordar a partir da coleção ESF. Em outras palavras, percebemos que seria preciso enfocar, também, outros instrumentos linguísticos de LE publicados no Brasil, que tiveram relevância para o ensino-aprendizagem

língua estrangeira, porém não se especifica qual língua na materialidade textual da referida lei. Assim, com base na análise que desenvolvemos, pudemos entender que a força do real prepondera em relação à indeterminação da LDB/1996 e produz o efeito de uma determinação discursiva de que seja o inglês a ocupar o estatuto disciplinar destinado às línguas estrangeiras em grande parte das escolas e, de maneira, predominante nas da rede pública. Por isso, nesse nível de ensino a LE fica quase que restrita ao âmbito das escolas particulares que, além do inglês, oferecem o ensino de espanhol na grade curricular como um diferencial. 
dessa língua e que antecederam a primeira edição de $E S F$.

Desse modo, concluímos que abriríamos dois arquivos - o jurídico e o dos instrumentos linguísticos - e que esses arquivos seriam relativos a domínios discursivos diferentes visto que o primeiro deles (o jurídico) caracteriza-se por apresentar uma organização prévia dos documentos que o compõe, dada pelas rotinas de uma metainstituição: o Estado. Isto é, os documentos do arquivo jurídico são classificados em decretos, resoluções, projetos de lei e as próprias leis que, por sua vez, são separados de acordo com a área a qual regulamentam (civil, criminal, trabalhista, etc.) e organizados com base nas datas de publicação. Já, os documentos que se relacionam ao arquivo dos instrumentos linguísticos não estão marcados por uma "pré-organização" e nem vinculados a uma determinada instituição. Porém, a partir da teoria de Pêcheux (2010), segundo a qual todo arquivo é interpretável, consideramos que poderíamos colocar em relação esses dois “campos de documentos" de domínios discursivos distintos por meio de nossa questão disparadora: detectar os sentidos atribuídos à LE em discursividades relativas ao espaço escolar e tentar compreender o processo pelo qual essa língua se filia, em tal espaço, a um estatuto que caracterizamos como "não-disciplinar".

Sendo assim, para estabelecer relações de sentido entre os dois arquivos que mobilizaríamos, organizamos nossa dissertação em duas partes. Na primeira delas, abordaríamos "documentos" do arquivo jurídico, relacionados ao ensino de línguas estrangeiras no Brasil, e, também, “documentos” do arquivo dos instrumentos linguísticos publicados desde a década de 20 a 80. De nosso ponto de vista, a análise desses arquivos, desenvolvida na primeira parte de nossa dissertação, nos permitiria conhecer as condições de produção da LE no contexto escolar do Brasil e, portanto, aspectos da memória discursiva que se instalou sobre essa língua no referido contexto. Já, na segunda, daríamos continuidade à abertura do segundo desses arquivos, ao focalizar o objeto central de nosso corpus - a coleção 
didática Español sin fronteras. A abordagem desta foi realizada a partir dos elementos paratextuais que definimos e da relação dos mesmos com os aspectos estudados na Primeira Parte de nossa pesquisa.

\section{3}

Uma vez exposta a composição de nosso corpus e a estrutura da pesquisa que nos permitiria abordar aspectos da memória discursiva sobre o espanhol no Brasil e de seu funcionamento com especial inflexão no espaço de enunciação escolar, procedemos à primeira dessas partes, cujas conclusões já desenvolvidas em relação aos dois arquivos que mobilizamos retomaremos nestas considerações finais.

A respeito do arquivo jurídico, identificamos, especialmente a partir dos dois documentos que trataram de maneira específica sobre o ensino de espanhol nas escolas, dizeres que, nesse espaço de enunciação e de acordo com nossa interpretação, filiaram a LE aos sentidos de uma língua de caráter "complementar". Com base na Exposição de Motivos da Reforma Capanema de 1942, os dizeres justificavam a inserção da LE na grade curricular oficial das escolas brasileiras primeiramente para completar o número mínimo determinado de línguas estrangeiras a serem ensinadas - lembremos que eram três e que o alemão havia sido excluído da grade curricular oficial. E, em segundo lugar, para complementar a carência de "recursos culturais" em "língua nacional". Já, por meio da Lei N. 11.161/2005, identificamos, com base na análise realizada por Rodrigues (2010), que a textualidade da mesma projeta sentidos que legitimam a disjunção entre as línguas estrangeiras ensinadas nas escolas e as ensinadas nos cursos livres. Essa disjunção é interpretada pela referida autora como fazendo parte de um processo que caracteriza como "desoficialização" das línguas estrangeiras no contexto de ensino regular. A pesquisadora ${ }^{275}$ considera que esse processo, no

\footnotetext{
${ }^{275}$ Ibidem, p. 113 .
} 
caso específico da LE, está materializado pelas "fissuras" possíveis de serem detectadas na materialidade dessa lei. Conforme a autora, tais "fissuras"- analisadas pela mesma com base nos artigos $1^{\circ}, 2^{\circ}, 3^{\circ}$ e $4^{\circ}$ da referida lei - deram margem, nos diferentes Estados do Brasil, a formas distintas de regulamentação do ensino dessa língua - e até mesmo de não regulamentação - e, ainda, contribuíram para que a LE, no espaço de enunciação escolar, ficasse vinculada muito mais ao âmbito extracurricular do que ao curricular, sendo ensinada e estudada nos Centros de Línguas Estrangeiras.

Assim, ante tais reflexões, interpretamos que essa passagem do estatuto de uma disciplina da grade "curricular" ao estatuto "extracurricular" (isto é, ser ensinada e estudada fora do horário regular de aulas, não ter uma nota inserida no boletim do aluno, não ser regulamentada pelas mesmas regras da instituição que norteiam as demais disciplinas, ter a opção de matrícula facultativa, etc.) configurou o que caracterizamos como uma relação de “informalidade" com o processo de ensino-aprendizagem da LE. Considerando essa interpretação à luz das teorias das ciências da educação, poderíamos ponderar que essa língua se vinculou ao conceito de educação não formal (cf. PARK; FERNANDES ${ }^{276}$, apud OLIVEIRA, 2008, p. 42), ou seja, embora o ensino de LE em Centros de Línguas também obedeça a uma estrutura e a uma organização podendo, inclusive, oferecer uma certificação, estas são distintas daquelas seguidas pelas escolas regulares e divergem, ainda, do que se entende como educação formal, no que respeita a não fixação de tempos e locais e à flexibilidade na adaptação dos conteúdos. Tais aspectos que caracterizam o conceito de educação não formal se relacionam com os elementos que mencionamos nos parêntesis acima e que são responsáveis, de nossa perspectiva, por "não formalizar" a LE para que esta se “ajeite no lugar já feito" que supõe o estatuto de uma disciplina na escola.

Ainda seguindo tais reflexões, porém agora com base nos instrumentos linguísticos de

276 A obra citada por Oliveira (2008) é: PARK, Margareth Brandini; FERNANDES, Renata Sieiro (org.). Educação não forma: contextos, percursos e sujeitos. Campinas - Holambra: Unicamp/CMU - Ed. Setembro, 2005. 
LE que pinçamos entre os anos 20 e final dos 80, observamos - a partir dos sentidos projetados para o espanhol - que foi uma contradição histórica a que operou na base do funcionamento da memória discursiva sobre essa língua: aquela sustentada pelo jogo de pares dicotômicos - "semelhança" e "facilidade" / "diferença" e dificuldade"277 - que, como analisamos a partir do estudo de Celada (2002), acreditamos ter sido fundada no discurso da Introdução da Gramática de Nascentes. Por meio do desenvolvimento de nossas análises, ao longo do segundo capítulo desta dissertação, pudemos perceber, por um lado, que tal contradição continuou em funcionamento na memória discursiva sobre a LE e, por outro, que foi dando sustento à relação específica do brasileiro com o ensino-aprendizagem dessa língua, principalmente no contexto escolar, que, a partir de uma série de antecipações, é marcada pela "informalidade", ou pela "não formalidade", conforme as reflexões que apresentamos nestas considerações $^{278}$.

Assim, identificamos uma série de sentidos fortemente vinculados a essa- contradição e, desse modo, pudemos delimitar um domínio de saberes e dizeres - isto é uma formação discursiva - que, de nossa perspectiva, passou a interpelar de maneira dominante o sujeito brasileiro em sua relação com a língua espanhola e, principalmente, em contexto de ensino-

\footnotetext{
${ }^{277}$ A respeito desse jogo de pares dicotômicos "semelhança" e "facilidade" / "diferença" e dificuldade" que consideramos ter sido fundado na Introdução da Gramática de Nascentes e determinado o funcionamento da memória discursiva sobre a LE no Brasil bem como a relação do brasileiro com o ensino-aprendizagem dessa língua, consideramos válido mencionar a organização do "Seminario de Dificultades Específicas de la Enseñanza del Español a Lusohablantes", destinado, especialmente, a estudantes brasileiros. Este Seminario é organizado pela Consejería de Educación de la Embajada de España en Brasil, pelo Instituto Cervantes e pelo Colégio Miguel de Cervantes de São Paulo e já está em sua vigésima edição.

${ }^{278}$ Neste ponto, é válido retomar um fragmento da entrevista que realizamos à prof ${ }^{a}$ González no qual a mesma fala sobre a relação dos alunos com o ensino da língua espanhola na década de 60 nas escolas brasileiras e vincula a essa relação sentidos que, nesta pesquisa, caracterizamos como "informalidade" ou "não-formalidade":

SdG_f: Agora, a respeito da relação com a língua, sempre foi isso: era uma língua muito parecida, a gente pensava em dar conta dela e, claro, como era por apenas um ano, também não chegávamos a um grau de aprofundamento. Quero dizer, nunca tivemos nenhuma exigência como, por exemplo, de falar em espanhol ou de escrever textos. Tínhamos apenas que ler, entender, repetir algumas coisas e fazer os exercícios. Você não percebia nenhum objetivo como: você vai ter que, ao final desse ano, estar falando espanhol muito bem ou estar escrevendo muito bem. Não, não tinha isso. (linhas 96-103 - grifos nossos)
} 
aprendizagem. Nesse domínio, destacamos num primeiro nível, dizeres que atribuíam à LE sentidos de "semelhança" e "parentesco" com a língua portuguesa e que remetiam, automaticamente, aos de "facilidade" na aprendizagem dessa língua por parte de estudantes brasileiros. E, num segundo nível, observamos alguns deslocamentos. Estes materializavamse discursivamente nas introduções ou textos introdutórios dos instrumentos linguísticos que analisamos, especialmente naqueles publicados entre os anos 70 e 80 (o Curso Práctico de Frigério e a coleção Vamos a Hablar), a partir de formas de dizer que projetavam os seguintes sentidos para a LE: viabilizar uma aprendizagem facilitadora mediante os métodos utilizados para seu ensino (e não especificamente de uma língua de fácil aprendizado); proporcionar o deleite; apresentar o estudo como um "convite", despertar a paixão por essa língua; aprender a usá-la corretamente, estudá-la "com grande rigor científico" e de "forma sistemática"; e, por fim, "evitar" o portunhol. Destarte, consideramos que tais sentidos vinculam-se com o enunciado presente na introdução à Gramática de Nascentes que afirma ser "de grande vantagem para os brasileiros o conhecimento não perfunctório" do espanhol. De acordo com a análise que desenvolvemos com base no trabalho de Celada (2002), a negação presente nesse enunciado - "não perfunctório" - permite identificar o funcionamento do préconstruído segundo o qual o estudo "perfunctório" da LE era antecipado como possível. Dessa maneira entendemos que os sentidos identificados no dizer dos instrumentos linguísticos das décadas de 70 e 80 que destacamos acima nos mostram um sujeito do discurso tomado pelo funcionamento da referida contradição e que, assim, realiza gestos que tentam "contornar" os efeitos desse funcionamento. Destarte, esse sujeito "convida" o brasileiro a estudar a LE e promete-lhe o "deleite" com esse estudo, porém o adverte sobre a importância de que estude essa língua "com grande rigor científico" e de "forma sistemática", a fim de evitar o "portunhol". 
De acordo com essa análise, desenvolvida na primeira parte de nossa dissertação, passamos à segunda parte da mesma, na qual nosso foco seria a coleção didática "Español sin Fronteras", lançada no final da década de 90, em 1996, e reeditada até à atualidade, respectivamente em 2002 e 2007. Para enfocá-la, já partimos, portanto, dos aspectos que interpretamos em relação à memória sobre a LE e, também das condições de produção dessa língua e do momento de publicação da coleção ESF. Sendo assim, percebemos que o título dessa coleção - Español sin fronteras - funcionou como uma marca que sinalizava a projeção da LE como uma língua veicular. Destarte, ante essa percepção nos indagamos se o sujeito do discurso dessa coleção se identificaria com o domínio de dizeres e saberes que havíamos detectado e analisado na Primeira Parte de nossa pesquisa, isto é, com uma formação discursiva na qual a LE é filiada à série de sentidos que acabamos de apresentar e que está fortemente vinculada à contradição já referida; ou se o sujeito desse discurso se identificaria com uma nova série de sentidos sobre a LE que fosse capaz de provocar tensões na já regularizada ou, até mesmo, fazê-la "ruir".

\section{5}

Assim, ao longo do Capítulo 3 dedicamo-nos à análise dos elementos paratextuais que determinamos enfocar nessa coleção em suas duas primeiras edições e observamos que os sentidos neles materializados não condiziam com a série que o título parecia instalar ao ir na direção, de nosso ponto de vista, de significar o espanhol como uma língua veicular. Foi apenas com o decorrer da análise das capas da terceira edição e, principalmente, de sua apresentação que pudemos identificar a materialização desses sentidos sinalizados pelo título, 
isto é, aqueles capazes de projetar a LE como uma língua veicular. E, foi, também, a partir da apresentação dessa mesma edição que percebemos uma dissonância em relação a toda a análise que estávamos desenvolvendo no Capítulo 3. Um dos enunciados da apresentação da terceira edição de ESF afirmava que a coleção seguia, linearmente, seu objetivo desde a primeira edição, a saber: facilitar o acesso dos alunos de LE ao universo cada vez mais amplo de modo a participar nele com êxito. Entretanto, tal afirmação não condizia com a análise dos elementos paratextuais da coleção que havíamos desenvolvido até aquele ponto e que, conforme nossas interpretações, filiavam a LE, fundamentalmente, aos sentidos de uma língua que precisava despertar o interesse de estudo no brasileiro e superar as dificuldades para as práticas de seu ensino-aprendizagem no Brasil, na primeira edição; e, na segunda edição, ao sentidos de uma língua de acesso à cultura e de integração com os países hispano-americanos a fim de estimular um fortalecimento político em nível subcontinental.

Ante essa perspectiva de análise, pudemos identificar sentidos que projetam a LE como veicular na materialidade discursiva dos elementos paratextuais da terceira edição (e não das duas primeiras) e, portanto, consideramos que não seria pertinente a afirmação enunciada na apresentação dessa mesma edição de que a coleção seguira linearmente seu objetivo desde sua primeira edição.

\section{6}

Sendo assim, decidimos enfocar a apresentação da terceira edição, a fim de analisar e interpretar a irrupção da dissonância que identificamos em sua materialidade discursiva.

Nesse enfoque, chamou-nos a atenção, num outro enunciado, um equívoco em relação à ocorrência do conector adversativo pero em lugar de sino para ligar uma oração coordenada a outra que se configura como uma negação. Tal equívoco nos permitiu transpor os limites da 
sintaxe e interpretá-la no âmbito discursivo.

À luz dos estudos de Erloza (2007) a respeito dos referidos conectores adversativos, inferimos que esse equívoco sinalizava, justamente, a posição ocupada pelo sujeito do discurso dessa coleção, posição esta que não consegue se identificar-se com uma formação discursiva nova, cuja forma-sujeito dominante significasse a LE essencialmente como língua vinculada à globalização, ao Mercado, ao universo profissional, às relações políticoeconômicas, enfim, às necessidades e urgências do sujeito pragmático (cf. PÊCHEUX, 2006, p.33) atendidas pelo que se designa como "língua veicular".

Todo o percurso de análise trilhado na segunda parte de nosso trabalho levou-nos a inferir que os questionamentos apresentados por nossos alunos em relação à necessidade de estudar espanhol e que configuravam, para nós, na posição de docentes, um mal-estar, vinculam-se aos sentidos de uma formação discursiva que, no Brasil, regulou - e ainda regula - os dizeres sobre a LE e com a qual os sujeitos do discurso que enunciam sobre essa língua parecem ainda identificar-se. No âmbito da memória discursiva sobre a LE, essa FD funcionou a partir da contradição, "fundada" pela própria memória, que passou a determinar, historicamente, a relação do brasileiro com essa língua e a levar esse sujeito a ocupar uma posição que estaria sob os efeitos dessa contradição: de fato, como observamos na apresentação da terceira edição da $E S F$, o sujeito é "pego" pelo pero e não consegue passar ao sino de modo a refutar e anular os sentidos de que é possível aprender "una nиеva lengua sólo por el valor del idioma en si mismo”.

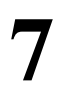

Já no âmbito do real, pensando de maneira específica no espaço da escola, entendemos que nessa formação discursiva materializaram-se o que consideramos como "fronteiras" (no sentido de limites, obstáculos, barreiras) que não permitiram - e ainda não permitem - ao 
sujeito brasileiro, submetido ao ensino-aprendizagem da LE, transpor as diferentes enunciações que questionam o porquê do estudo do espanhol e não abrem espaço para que essa língua se ajeite nas evidências e no lugar já-feito e suposto ao estatuto de uma disciplina no espaço escolar.

E, considerando o real como o espaço de enunciação que coincide com o da nação brasileira, percebemos, ainda, que a LE, mesmo vinculada à textualidade jurídica - nesse caso, a Lei N.11.161/2005, de âmbito federal - continua sendo significada com a série de sentidos que preponderam no funcionamento da memória sobre a LE e na formação discursiva que detectamos organizar os dizeres e saberes para essa língua. A esse respeito, parece-nos conveniente fazer referência às diversas cartas redigidas por associações de professores de língua espanhola e direcionadas a prefeituras de diferentes cidades, solicitando esclarecimentos sobre a forma de regulamentação da língua espanhola enquanto disciplina nas instituições de ensino da rede pública, bem como sobre os requisitos para contratação de docentes responsáveis pelo ensino dessa língua nas mesmas ${ }^{279}$. A partir dessas cartas, podemos notar como, tanto os critérios de inserção da LE na grade curricular das escolas regulares como os de seleção de docentes são diversos e, até mesmo, controversos aos estabelecidos pela Lei N. 11.161/ 2005 e pelo Título VI da LDB $^{280}$ de 1996 - que dispõe

\footnotetext{
${ }^{279}$ A esse respeito indicamos o acesso aos sites de duas Associações de Professores de Espanhol do Brasil, a de São Paulo e a do Rio de Janeiro respectivamente: <http://www.apeesp.com.br/web/?paged=2> e $<$ http://apeerj.blogspot.com> Acesso em: 05 mai. 2012). Neles é possível encontrar cartas dirigidas a secretarias de educação de diferentes municípios manifestando questionamentos sobre a inadequação da implantação do ensino de espanhol nas escolas públicas em relação às disposições estabelecidas pela Lei Federal 11.161 de 2005. Ademais, estas cartas são comentadas por professores de espanhol de outras regiões do Brasil, que relatam suas inquietações em relação a diferentes formas de descumprimento dessa Lei Federal.

${ }^{280}$ Em relação ao título VI da LDB de 1996, que dispõe sobre os profissionais da educação, destacamos o artigo 62 reformulado pelo decreto $\mathrm{n}^{\mathbf{0}} 3.276$, de 6 de dezembro de 1999. Consoante a reformulação do referido decreto, o inciso $4^{\circ}$ do artigo $3^{\circ}$ e o artigo $4^{\circ}$ dispõem, respectivamente que:

Art. $3^{\mathrm{o}}$

$\S 4^{0}$ A formação de professores para a atuação em campos específicos do conhecimento far-se-á em cursos de licenciatura, podendo os habilitados atuar, no ensino da sua especialidade, em qualquer etapa da educação básica.

Art. $4^{\mathrm{o}}$ Os cursos referidos no artigo anterior poderão ser ministrados:

I - por institutos superiores de educação, que deverão constituir-se em unidades acadêmicas específicas;

II - por universidades, centros universitários e outras instituições de ensino superior para tanto legalmente credenciadas. (disponível em <http://www.planalto.gov.br/ccivil_03/decreto/D3276.htm> acesso em 09 mar.
} 
sobre a formação necessária aos profissionais da educação e sobre os tipos de instituições capacitadas a oferecer essa formação.

Em suma, ante os dois arquivos compostos por "campos de documentos" de domínios discursivos diferentes que mobilizamos e colocamos em relações de sentido a partir de nossa questão norteadora, inferimos que, no Brasil, ainda não é possível considerar que o processo de regulamentação da língua espanhola como uma disciplina nas escolas esteja ocorrendo "sin fronteras" - e aqui voltamos a pensar este sintagma com o sentido que já explicitamos ou seja, "sem dificuldades" e "sem conflitos". De nosso ponto de vista, as tentativas de filiar a língua espanhola ao estatuto disciplinar nas escolas esbarram em "fronteiras". Estas, de um lado, são delimitadas por projeções imaginárias que começaram a sinalizar uma tensão no interior da FD em que, a partir da fundação e do funcionamento de uma memória discursiva sobre a LE no Brasil, se inscreveram determinados saberes e dizeres, porém tais projeções não foram capazes de fazer "ruir" a série de sentidos que de modo privilegiado se instalou na referida FD. E, de outro, tais "fronteiras", no sentido que aqui as interpretamos, são determinadas pelo/no real do espaço escolar no qual, historicamente, a língua espanhola não se "ajeitou nas evidências e no lugar já-feito" suposto ao estatuto de uma disciplina. Sendo assim, não poderíamos finalizar nossas considerações neste ponto, sem antes dizer que, no espaço escolar, por efeito da determinação discursiva que abordamos nesta dissertação, observamos que, no caso das línguas estrangeiras, esse estatuto continua sendo dado, de modo preponderante e quase homogêneo, apenas ao inglês.

E, assim, encerramos nossas considerações, porém não nosso trabalho de pesquisa sobre a LE que continua, como também permanece nosso desejo: o de que outras línguas também passem a habitar o espaço de enunciação escolar sob o estatuto de disciplinas, para que possamos pensar a escola como um espaço de "línguas sem fronteiras". 


\section{REFERÊNCIAS BIBLIOGRÁFICAS}

ÁLVAREZ, José Ramón Calleja. (1953). Español básico: para os cursos clássico e científico. São Paulo: Editora do Brasil, $2^{\mathrm{a}}$ ed. vol 9.

AUROUX, S. (1992). A Revolução tecnológica da gramatização. Campinas: Unicamp.

BARRETO, Talita de Assis. (2010). O professor formador de docentes de E/LE. Discursos sobre o trabalho. Dissertação (Doutorado em Programa de Pós-Graduação em Letras Neolatinas) - Universidade Federal do Estado do Rio de Janeiro.

BECKER, Idel. (1970) Manual de Español, 57ªed. (1ªed. de 1945), São Paulo: Nobel

BERTOLDO, Ernesto Sérgio (2003). O contato-confronto com uma língua estrangeira: a subjetividade do sujeito bilíngue. In: Coracini, M. J. R. F. (Org.) Interpretação, autoria e legitimação do livro didático: língua materna e língua estrangeira. $1^{\mathrm{a}}$ ed. Campinas, SP: Pontes, p. 83-118.

CAMPOS, Lilian Dutra. (2006) O francês como disciplina escolar no gymnásio paranaense no primeiro período da Era Vargas (1930-1945). In: Anais do VI Congresso LusoBrasileiro de História da Educação. Uberlândia, Minas Gerais, Eixo temático 6 cultura, modelos pedagógicos e práticas educativas, p. 4891-4900. (Disponível em < http://www.faced.ufu.br/colubhe06/anais/arquivos/448LilianDutraCampos.pdf $>$ Acesso em 23 jan.2011)

CARVALHO, Valceli Ferreira. (2010) A língua inglesa no ensino básico: processo de identificação no contexto de uma escola pública. Dissertação (Mestrado no Programa de Pós Graduação em Estudos Linguísticos e Literários em Inglês) Universidade de São Paulo. Disponível em: <http://www.teses.usp.br/teses/disponiveis/8/8147/tde-04012011094713/fr.php> Acesso em 23 jan.2011.

CASANOVA, Julián. (2000) República y guerra civil. In: FONTANA, Josep; VILLARES, Ramón (directores). Historia de España. Barcelona: Crítica, volumen 8, pp. 339-361.

CELADA, María Teresa. (1993). A fundação de um destino para a pátria argentina. In: ORLANDI, Eni Puccinelli (org.) Discurso fundador: a formação do país e a construção da identidade nacional. Campinas - SP: Pontes, p. 89-112.

(2002) O espanhol para o brasileiro: uma língua singularmente estrangeira. Tese (Doutorado no Instituto de Estudos Linguísticos) Universidade Estadual de Campinas, SP.

CORACINI, Maria José R. Faria. (2003). Língua estrangeira e língua materna: uma questão de sujeito e identidade. In: Coracini, M. J. R. F. (org) Identidade e Discurso: (des)construindo subjetividades. Chapecó/Campinas: Argos/Ed. Unicamp, pp. 139-159.

COURTINE, Jean-Jacques. (2009) Análise do discurso político. O discurso comunista endereçado aos cristãos. 1981. São Carlos: EDUFSCar. 
DE NARDI, Fabiele Stockmans (2004). Entre a estrutura e o acontecimento: Uma releitura de Pêcheux e Foucault em busca do sistema. Disponível em < http://www.discurso.ufrgs.br/article.php3?id_article=13 > Acesso em 19 jan.2012.

(2010). Espaços de identificação: um olhar discursivo sobre a cultura em livros didáticos para o ensino de língua espanhola. In: I Congresso Internacional de Língua Oficiais do MERCOSUL, Foz do Iguaçú. Anais do Congreso Internacional de Profesores de Lenguas Oficiales del Mercosur, p. 395-406.

DINIZ, Leandro Rodrigues Alves. (2010) Representações da língua portuguesa em livros didáticos brasileiros de ensino de português como língua estrangeira. In: CELADA, M. T.; FANJUL, A. P.; NOTHSTEIN, S. (coord.) Lenguas en un espacio de integración: acontecimientos, acciones, representaciones. $1^{\mathrm{a}} \mathrm{ed}$. Buenos Aires: Biblos, p. 129-144.

ECKERT-HOFF, Beatriz Maria. (2010) (Dis)Sabores da Língua Ma(e)terna: os conflitos de um entre-lugar. In: ECKERT-HOFF, Beatriz Maria; CORACINI, Maria José Rodrigues Faria. (org.) Escrit(ur)a de si e alteridade no espaço papel-tela: alfabetização, formação de professores, língua materna e estrangeira. Campinas: Mercado das Letras, pp. 79-106.

ERLOZA, Rosa María Espinosa (2007) Aspectos generales de la evolución de lasexpresiones adversativas: cambios en cadena. In: Medivalia, n. 39. Disponível em < http://www.revistas.unam.mx/index.php/medievalia/article/view/28963> Acesso em $21 \mathrm{dez}$. 2011.

FERNÁNDEZ, I. Gretel M. Eres. (2000). La producción de materiales didácticos de español lengua extranjera en Brasil In: Anuario Brasileño de Estudios Hispánicos, pp. 59-80. Disponível em: <http://www.mec.es/sgci/br/es/publicaciones/anuario/abeh2000s.pdf> Acesso em 10 jan.2009.

FOUCAULT, (2008). A ordem do discurso. $16^{\mathrm{a}}$ ed. Rio de Janeiro: Edições Loyola.

FREUD, Sigmund. (1997) O mal-estar na civilização. Rio de Janeiro: Imago.

FRIGÉRIO, Francisco. (1977). Curso práctico de español. Curitiba, PR: Arco-íris, $4^{\mathrm{a} e d .}$

GARCÍA, María de los Ángeles Jiménez; HERNÁNDEZ, Josephine Sánchez. (1996). Español sin Fronteras. São Paulo: Scipione, vol. 1, 2, 3 e 4. (2002). Español sin Fronteras. São Paulo: Scipione, vol. 1, 2, 3 e 4. (2007). Español sin Fronteras. São Paulo: Scipione, vol. 1, 2, 3 e 4.

GASPARINI, Pablo. (2009). El etnotipo latinoamericano en los textos de ELE: análisis de dos casos. In: SIGNOS ELE, octubre. Disponível em <http://www.salvador.edu.ar/signosele/> Acesso em 22 out.2011.

GENETTE, Gérard. (2009) Paratextos Editoriais. Tradução de Álvaro Faleiros. Cotia/SP: Ateliê, $372 \mathrm{p}$. 
GONZÁLEZ, Neide Maia. (2005) El español em Brasil: um intento de captar el orden de la experiência. In: Sedycias, João [et al.] (Orgs.) O ensino do espanhol no Brasil: passado, presente, futuro. São Paulo: Parábola Editorial, p. 71-76

GRIGOETTI, Lúcia Valquíria Souza. Multilinguismos, vozes paralelas em espiral: línguas integradas ou cindidas, ou, mais que isso, línguas traduzidas. In: Anais do CELSUL, 2008. Disponível em http://www.celsul.org.br/Encontros/08/vozes_paralelas_em_espiral.pdf > Acesso em 11 jan.2012.

GUIMARÃES, Eduardo. (1998). Interdiscurso, textualidade e argumentação. In: Signo\&Seña, $N^{\circ}$ 9. Buenos Aires: Instituto de Linguística/Universidade de Buenos Aires.

(2000). Língua de civilização e língua de cultura. A língua nacional do Brasil. In: BARROS, Diana Luz Pessoa de (org.) Os discursos do descobrimento: $500 e$ mais anos de discursos. São Paulo: Editora da Universidade de São Paulo; FAPESP, pp. 169-180.

(2005) Enunciação e Acontecimento. In: GUIMARÃES, E. Semântica do acontecimento: um estudo enunciativo da designação. Campinas: Pontes, pp. 11-31.

HENRY, Paul. Construções relativas e articulações discursivas. Cadernos de Estudos Linguísticos, Campinas: Editora da Unicamp, v.19, p. 43-64, jul./dez. 1990.

IANNI, Octavio. Teorias da globalização. 9.ed. Rio de Janeiro: Civilização Brasileira, 2001, pp. $11-26$

INDURSKY, F. (1997) A fala dos quartéis e as outras vozes. Campinas: Editora da Unicamp. (2008) Unicidade, desdobramento, fragmentação: a trajetória da noção de sujeito em Análise do Discurso. In: MITTMANN, Solange; GRIGOLETTO, Evandra; CAZARIN, Ercília (Orgs.). Práticas Discursivas e identitárias; Sujeito \& Língua. Porto Alegre, Nova Prova, PPG-Letras/UFRGS (Col. Ensaios, 22).

JIMENÉZ, Felipe B. Pedraza; CÁCERES, Milagros Rodríguez. (1992) Vamos a Hablar: curso de lengua espanhola. $4^{\mathrm{a}}$ ed. Ática: São Paulo.

LAGAZZI, Suzy-Rodrigues. (1998) A discussão do sujeito no movimento do discurso. Tese (Doutorado no Instituto de Estudos da Linguagem) Universidade Estadual de Campinas, SP.

LEWKOWICZ, Ignacio. (2003) Condiciones post-jurídicas de la ley. In: Internacional deseo de ley. tomo 1, Editorial Biblos: Buenos Aires, p.39-53.

LYONS, Jonh. (1987) Linguagem e lingüística: uma introdução. Rio de Janeiro: Livros Técnicos e Científicos Editora S.A.

MAGNOLI, Demétrio Martinelli.(1997) Globalização, Estado nacional e espaço mundial. São Paulo: Moderna, pp. 44-58)

MARIANI, Bethania. (2004). Colonização Linguística. Campinas, SP: Pontes. 
NASCENTES, Antenor (1934). Gramática da língua espanhola para uso de brasileiros. Rio de Janeiro: Pimenta de Mello, $4^{\mathrm{a}}$ ed.

ORLANDI, Eni Puccinelli. (1988a). Nem escritor, nem sujeito: apenas autor. In: Discurso e leitura. São Paulo: Cortez; Campinas: Editora da Universidade Estadual de Campinas, p.75-83.

ORLANDI, E. P. (org.) (1988b) Política linguística na América Latina. Campinas: Pontes.

Campinas, SP: Editora da UNICAMP.

(1992). As formas do silêncio: no movimentos dos sentidos.

. (2003). Prefácio. In: ORLANDI, Eni Puccinelli (org.) Discurso

fundador: a formação do país e a construção da identidade nacional.Campinas - SP: Pontes, p. 11-26.

. (2005). A língua brasileira. In: Ciência e Cultura, São Paulo, v.

57, n. 2, Junho de 2005. Disponível em:

$<$ http://cienciaecultura.bvs.br/scielo.php?script=sci_arttext\&pid=S0009-

$67252005000200016 \& \operatorname{lng}=$ en\&nrm=iso $>$ Acesso em 22 fev. 2011.

Campinas, SP: Pontes.

(2007a). Análise do discurso: princípios e procedimentos. $7^{\mathrm{a}} \mathrm{ed}$.

(2007b). Processo de identificação sujeito/língua. Ensino, Língua

Nacional e Língua Materna. In: ORLANDI, Eni Puccineli (org.). Política Linguística no Brasil. Capinas, SP: Pontes, pp. 113-123.

OLIVEIRA, Cristiane Gonçalves de. (2008) Educação não formal de crianças $e$ adolescentes: expectativas quanto ao programa de núcleos comunitários em Campinas, $S P$. Dissertação (Mestrado no Programa de Pós Graduação em Educação) Universidade de São Paulo. Disponível em <http://www.teses.usp.br/teses/disponiveis/48/48134/tde12062008-153428/pt-br.php> Acesso em: 05 jun. 2012.

PAYER Maria Onice. (1995) Educação popular e linguagem: reprodução, confrontos e deslocamentos de sentidos. Campinas, São Paulo: Editora da Unicamp.

(2006). Memória da língua: imigração e nacionalidade. São Paulo,

Ed. Escuta.

. (2007b). Processo de identificação sujeito/língua. Ensino, Língua

Nacional e Língua Materna. In: ORLANDI, Eni Puccineli (org.). Política Linguística no Brasil. Capinas, SP: Pontes, pp. 113-123.

PÊCHEUX, Michel. (1990). Remontemos de Foucault à Spinoza. In: MALDIDIER, Denise. L'Inquiétude du discours. Textes choisis par D. Maldidier. Paris: Cendres, 1990. p. 245-260. Edição Original: 1977. Trad. de Maria do Rosário Gregolin. Mimeo, 2000.

(1988) Semântica e discurso: uma crítica à afirmação do óbvio. 3.ed.

Campinas: Editora da Unicamp. 
. (1999). Papel da memória. In: ACHARD, Pierre. Tradução e Introdução de José Horta Nunes. Papel da Memória, Campinas. SP: Pontes, pp.49-57.

.(2006) O discurso: Estrutura ou acontecimento. Tradução de Eni

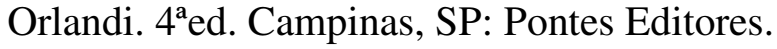

(1969). Análise automática do discurso. In: GADET, Françoise; HAK, Tony (orgs.) (2010) Por uma análise automática do discurso: uma introdução à obra de Michel Pêcheux. trad. Bethania S. Mariani...[et al], 4 ed., Campinas, SP: Editora da Unicamp.

. (2010). Ler o arquivo hoje. In. ORLANDI, Eni (org.) Gestos de leitura. Campinas: Editora da Unicamp, $3^{\mathrm{a}}$ ed.

PENHA, João Alves Pereira. Filólogos Brasileiros. Franca: Editora Ribeirão Gráfica, 2002, p. 67-72. Disponível em <http://www.filologia.org.br/xcnlf/homenageado.html> Acesso em 20 dez.2011.

PICANÇO, Deise Cristina de Lima (2003). História, memória e ensino de espanhol (19421990). Curitiba: Editora da UFPR.

REVUZ, C. (1998) A língua estrangeira entre o desejo de um outro lugar e o risco de exílio. Tradução de Silvana Serrani-Infante. In: SIGNORINI, I. (Org.). Lingua(gem) $e$ Identidade: elementos para discussão num campo aplicado. Campinas: Mercado de Letras, p.213-230.

RODRIGUES, Fernanda dos Santos Castelano. (2010) Língua viva, letra morta. Obrigatoriedade e ensino de espanhol no arquivo jurídico e legislativo brasileiro. Dissertação (Doutorado no Programa de Pós-Graduação em Língua Espanhola e Literatura Espanhola e Hispano-Americana) Faculdade de Filosofia, Letras e Ciências Humanas da Universidade de São Paulo. Disponível em: $<$ http://www.teses.usp.br/teses/disponiveis/8/8145/tde-07072010-162106/es.php > Acesso em 23 jan.2011.

SERRANI-INFANTE, Silvana M. (1993). Ressonâncias fundadoras e imaginário de língua. In: ORLANDI, Eni Puccinelli (org.) Discurso fundador: a formação do país e a construção da identidade nacional.Campinas - SP: Pontes, p. 113-126.

SERRANI-INFANTE, S. Diversidade e alteridade na enunciação em línguas próximas. In Letras, jan-junio 1997, 1-19.

SILVA, Mariza Vieira da. (1996) O dicionário e o processo de identificação do sujeitoanalfabeto. In: GUIMARÃES, Eduardo; ORLANDI, Eni Puccinelli (Orgs.) Língua e cidadania: o português no Brasil. Campinas, SP: Pontes, p. 151-162.

SILVA, Ana Margarida Dutra de Oliveira. (2009) Motivação para aprendizagem de Espanhol/Língua Estrangeira em turmas de Ensino Médio. Dissertação de Mestrado. Taubaté - São Paulo. Disponível em: <http://www.unitau.br/cursos/posgraduacao/mestrado/linguistica-aplicada/dissertacoes-2/dissertacoes-2009/20072009\%20\%20SILVA,\%20Ana\%20Margarida\%20Dutrade\%20Oliveira.pdf.> Acesso em 15 fev. 2010 
SILVA, José Renato. (2010). A LDB de 1961: língua e educação na configuração nacional. Um percurso na história. Tese de Doutorado. Campinas - São Paulo.

SOUSA, Greice de Nóbrega. (2007). Entre línguas de negócios e de cultura: sentidos que permeiam a relação do brasileiro com a língua inglesa e espanhola. Dissertação (Mestrado no Programa de Pós-Graduação em Língua Espanhola e Literatura Espanhola e Hispano-Americana) Faculdade de Filosofia, Letras e Ciências Humanas da Universidade de São Paulo.

SOUZA, Deusa Maria de. (1999). Autoridade, autoria e livro didático. In: Coracini, M. J. R. F. (org) Interpretação, autoria e legitimação do livro didático: língua materna e língua estrangeira. $1^{\text {a }}$ ed. Campinas, SP: Pontes, p. 27-31.

SOUZA, Deusa Maria de. (1999). Livro didático: Arma pedagógica. In: Coracini, M. J. R. F. (org) Interpretação, autoria e legitimação do livro didático: língua materna e língua estrangeira. $1^{a}$ ed. Campinas, SP: Pontes, p. 93-104.

SOUZA, Sérgio Augusto Freire de. (2005). O movimento dos sentidos sobre línguas estrangeiras no Brasil: discurso, história e educação. Tese de Doutorado. Campinas - São Paulo.

TORQUATO, Cloris Porto. (2010) Políticas lingüísticas, linguagem e interação social. In: Revista Escrita. $\mathrm{n}^{\mathrm{o}}$ 11. Disponível em http://www.maxwell.lambda.ele.puc-

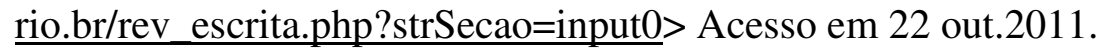

ZOPPI-FONTANA, Mónica G. (2003) Lugares de enunciação e discurso. In: Boletim da Associação Brasileira de Linguística, vol.1, p.199-201. 


\section{ANEXOS}

\section{PARTE A}

Anexo A - Orientações sobre a realização da entrevista à professora doutora Neide Maia González.

A entrevista que apresentamos editada no anexo seguinte foi realizada em 05 de julho de 2011, com Neide Maia González, professora doutora aposentada da Faculdade de Filosofia Letras e Ciências Humanas da Universidade de São Paulo, onde foi docente do Curso de Letras/Habilitação Espanhol e no qual formou professores e pesquisadores de língua espanhola desde 1972 até 2008 (com uma interrupção de quatro anos no meio). A referida entrevista ocorreu na sala de professores da referida Faculdade e teve duração de 33 minutos e 45 segundos. Elaboramos um roteiro prévio para nortear e direcionar a entrevista e a ele acrescentamos algumas intervenções durante a realização da mesma, à medida que consideramos necessário.

Esclarecemos, ainda, que selecionamos a professora González para realizar essa entrevista não apenas por sua vasta experiência e conhecimento na área do ensinoaprendizagem da LE no Brasil, mas, sobretudo pelo fato de que a mesma vivenciou parte do período em que o ensino de LE foi inserido por primeira vez nos currículos das escolas brasileiras. Nesse sentido, o tema das perguntas desta entrevista está relacionado, fundamentalmente, às recordações que nossa entrevistada tem desse período no qual estudou espanhol na escola.

Por fim, salientamos que o foco desta entrevista foi analisar sua dimensão discursiva e, assim sendo, transcrevemo-la na ordem em que as perguntas foram feitas e as respostas dadas, preservando os termos utilizados pela entrevistada, porém sem considerar aspectos fonéticos e fonológicos, como pausas, entonações, superposição de vozes, entrucamentes, prologamentos de vogais, etc. 
Anexo B - Transcrição editada da entrevista concedida pela prof ${ }^{\mathrm{a}}$ Dr $^{\mathrm{a}}$ Neide Maia González, docente de língua espanhola do Departamento de Letras Modernas da Faculdade de Filosofia, Letras e Ciências Humanas da Universidade de São Paulo.

Observações: P: Priscila Oliveira Vieira

\section{N: prof ${ }^{a}$ Dra $^{\text {a }}$ Neide Maia González}

1 P: Primeiramente, peço-lhe que me informe alguns de seus dados pessoais, como: nome 2 completo.

3 N: Claro, meu nome é Neide Therezinha, com "th" e com "z", Maia González, com "z" $4 \quad$ no meio e no final.

5 P: Qual a sua data de nascimento?

$6 \quad$ N: Essa é terrível: 22 do 09 de 1944.

$7 \quad$ P: Qual a sua nacionalidade?

$8 \quad$ N: Sou brasileira e paulista, de São Paulo.

$9 \quad$ P: E o seu grau de instrução?

$10 \quad$ N: Tenho doutorado.

11 P: E a sua profissão é professora, certo?

$12 \quad$ N: Isso mesmo.

13 P: Certo. Então, a primeira pergunta é: em que ano e em que escola você começou a ter aulas 14 de espanhol na grade curricular?

15 N: Deixa eu ver, eu não sei se vou me lembrar do ano em que eu tive espanhol. Não me 16 lembro se foi no primeiro, no segundo ou no terceiro ano do clássico. Sabe o que é não 17 lembrar? Mas eu acho que não foi no primeiro, não.

18 P: Não?

19 N: Olha, o ano vai ser mais complicado, porque eu não me lembro em qual dos três foi, 20 mas vamos colocar entre sessenta e três ou sessenta e quatro. Mas, no primeiro eu tenho 21 praticamente certeza que não foi. Deve ter sido no segundo ou no terceiro ano, entre 22 sessenta e três e sessenta e quatro.

23 P: Tudo bem. Você se lembra do nome da escola?

24 N: Foi o Colégio Estadual Presidente Roosevelt. 
P: Você teve conato com a língua espanhola antes de estudá-la na grade curricular? De que maneira esse contato aconteceu?

N: Eu tive sim e de várias formas. Primeiro, eu cheguei a ouvir bastante espanhol com vizinhos que eram imigrantes. Inclusive, eu tive uma amiga muito próxima que era filha de um espanhol e a mãe era nascida na Argentina, mas filha de espanhóis também. Então, eu tive contato com o espanhol assim, nessa espontaneidade, ouvindo músicas porque, na época, as músicas faziam bastante sucesso. E, depois, já no ginásio mesmo, a gente tinha que fazer pesquisas na biblioteca e muitas das coisas que a gente tinha que pesquisar estavam escritas em espanhol. Eu me lembro de ter feito, desde muito cedo, já na terceira ou quarta série da época, leituras de livros em espanhol para fazer trabalhos da escola.

\section{P: E que outras línguas, além do espanhol,, você estudou na escola?}

N: Na escola eu estudei francês e inglês. Na minha geração mais francês do que inglês, inclusive. Eu tive muito contato com o italiano também, mas isso, por razões familiares e, depois, fiz um curso num instituto.

P: Como eram as aulas de espanhol? Você se lembra de algo sobre o professor: se era usado algum material didático, se vocês estudavam questões gramaticais, se havia algum tipo de avaliação, se recebiam alguma nota por isso, etc.?

N: Então, eu não me lembro desse detalhe, teria que buscar o meu histórico escolar para ver essa questão da nota, mas eu acredito que sim. Tudo tinha uma nota naquela época. Nós estudávamos com o livro do Idel Becker e durante um ano. E, nesse ano, nós seguimos, eu diria, bem à risca, o livro do Idel Becker. Eu tive duas professoras. A primeira se afastou e veio uma outra professora. Do nome da primeira eu me lembro bem: era Berta. Mas, do nome da segunda eu não me lembro, pois foi uma coisa muito rápida. A primeira delas era mais estruturada, ela seguia o livro à risca. $\mathrm{E}$, a segunda era mais jovem, então ela trazia muita música. Eu me lembro que a gente cantava boleros. Eram as músicas que, na época, estavam na moda. Eu nunca me esqueci de um bolero que ela ensinou para a gente, que se chama "La barca". Eu decorei aquela música, aquela letra. Aquilo ficou na minha cabeça e a gente se divertia muito nessas aulas, porque essa segunda professora era muito simpática, muito divertida. Eu tenho a impressão de que a gente tinha a sensação de que não tínhamos grande compromisso com aquilo, ou seja, era alguma coisa que era mais divertida do que as outras coisas que nós tínhamos que estudar loucamente. $O$ francês era muito duro, o português com a literatura era, na época do clássico, um curso bem pesado, um curso muito forte.

P: E essas professoras eram nativas, ou não?

N: Não, nenhuma das duas era nativa. As duas eram brasileiras e tinham feito na USP, quando na USP ainda havia o curso de letras neolatinas. Fazia-se, fundamentalmente o português e o francês e a segunda língua era escolhida, podendo ser ou o italiano ou o espanhol. Elas tinham escolhido o espanhol, eu lembro que elas nos contaram. E elas usavam bastante o Manual, com tudo o que ele trazia. Ou seja, a gente aprendia, lia os textos, decorava os poemas. A segunda, como eu já disse, também trazia canções que a gente aprendia e cantava. E fazíamos, também, os exercícios do livro, seguindo bem a linha do Manual e uma linha de ensino que, na época, era muito comum, quer dizer, 
comum para o ensino de língua estrangeira. Acho que, na época, praticamente todas as línguas que estudei, estudei dessa maneira.

P: Você se lembra se a escola, ou até mesmo alguma dessas professoras, apresentou alguma explicação referente à inserção da língua espanhola na grade curricular?

N: Nenhuma. Eu não me lembro. Isso é uma coisa que eu sempre me questiono, pergunto para mim mesma. Na época, ninguém, nem nós, alunos, perguntávamos "por que nós temos isso ou não temo aquilo". Ou seja, era aquilo e a gente tinha que estudar. Fazia parte e a gente estudava. E, como a escola era muito exigente, muito mesmo - o Roosevelt era uma escola de ponta, considerada escola modelo de São Paulo - era apertadíssimo. Então, a gente levava tudo muito a sério, porque realmente era muito complicado. Por isso, nunca questionamos, nem nunca se explicou: "vocês vão estudar espanhol porque" ou "com essa finalidade".

P: O estudo de espanhol foi durante um ano apenas?

N: Exatamente.

P: E você lembra como era relação dos demais alunos, de modo geral, com a aprendizagem do espanhol: se eles gostavam de estudar, se havia algum questionamento, se eles reconheciam a importância dessa língua, se eles a consideravam fácil ou difícil. Enfim, os comentários que faziam?

N: Todo mundo achava, em princípio, mais fácil porque todos tinham tido algum tipo de contato com essa língua, fosse pela vizinhança, fosse pela família ou fosse por essa necessidade que, muitas vezes, a gente tinha de fazer pesquisas utilizando livros escritos em espanhol ou livros traduzidos para o espanhol, que eram mais acessíveis. Havia mais traduções de obras de referência ao espanhol do que ao português. Eu, realmente, não me lembro de ninguém questionar as aulas que, como eu disse a você, eram divertidas. Eram as aulas em que a gente mais relaxava porque o grau de compromisso era pequeno, já que sabíamos que eram apenas por um ano. Então, era uma disciplina que tínhamos que dar conta para passar de ano. Não era uma coisa comum da época você entrar em grandes questionamentos, "Por que está?", "Por que tem isso?". Fazia parte do currículo e todo mundo aceitava e estudava para passar. Agora, a respeito da relação com a língua, sempre foi isso: era uma língua muito parecida, a gente pensava em dar conta dela e, claro, como era por apenas um ano, também não chegávamos a um grau de aprofundamento. Quero dizer, nunca tivemos nenhuma exigência como, por exemplo, de falar em espanhol ou de escrever textos. Tínhamos apenas que ler, entender, repetir algumas coisas e fazer os exercícios. Você não percebia nenhum objetivo como: você vai ter que, ao final desse ano, estar falando espanhol muito bem ou estar escrevendo muito bem. Não, não tinha isso.

P: Enquanto estudante da educação básica, você teve outro contato com o ensinoaprendizagem da língua espanhola fora da escola? Onde e quando? 
N: Sim.

P: Com qual?

N: Com o italiano, o francês e o inglês. $O$ italiano era a língua da minha família e eu terminei indo fazer um curso rápido, também, no Instituto Cultural Ítalo-Brasileiro. Já o inglês eu estudei um tempo na União Cultural Brasil/Estados Unidos. E, o francês, eu estudei desde o primário porque, o final desse ciclo, eu estudei com umas freiras que eram francesas. Depois, eu fiz francês no ginásio e, mais para frente, eu ganhei uma bolsa para estudar na Aliança Francesa. Portanto, o francês foi a língua com a qual eu mais tive contato.

P: E você considera que o contato que teve com a língua espanhola naquele período da escola teve alguma relação com a sua escolha profissional? Por quê?

N: Nenhuma. Inclusive, veja, eu não optei pelo espanhol quando eu fiz o vestibular. Quando eu fiz o vestibular ainda era para o curso de letras neolatinas - eu sou dessas gerações que pegaram todas as mudanças, é muito engraçado. Quando eu estudei o espanhol na escola, no ano seguinte essa língua saiu da grade curricular. Já, o francês, eu tive pilhas de aulas, foi a língua que eu mais estudei na vida, fora o português. Quando eu fui fazer o vestibular, primeiro prestei para filosofia. Fiz três anos de Lá, os meus professores diziam: "Você precisa do diploma em letras", "Você precisa ensinar francês", "Você precisa não sei o que...”, etc. Então, eu resolvi fazer o vestibular no final de sessenta e sete e começo de sessenta e oito e entrei no curso de Letras em sessenta e oito. Foi assim: eu fiz o vestibular para letras neolatinas e, portanto, precisava escolher outra língua além do português, do latim e do francês, já obrigatórias. Assim, ou você fazia um prova de italiano ou de espanhol. Como eu era descendente de italianos e tinha falado e ouvido muito italiano na minha infância, eu falei: "Vou fazer italiano!" E fiz, então, o vestibular para essa língua. Ou seja, eu entrei em letras neolatinas português/francês/italiano. Aí, eu comecei a cursar o italiano na faculdade e era muito ruim, na época. Era bem ruim e bem fraco! Eu lembro que a gente ia à uma salinha e ficava repetindo palavras até que saísse la zeta ou le doppie como a professora queria. Imagine que ela usava flanelógrafo que, naquela época, já era antiquado e a gente dava muita risada. A última vez que eu tinha visto um flanelógrafo foi no jardim da infância. Então, era algo já completamente superado, pois a gente tinha, naquela época, alguns meios audiovisuais. Eu já tinha feito cursos, inclusive para ensinar francês, na própria Aliança Francesa com métodos audiovisuais. Então, eram muito chatas as aulas de italiano da faculdade. Tínhamos vocabulário, a gente repetia palavras soltas, algo completamente antiquado para a época.

Ao mesmo tempo em que eu fazia isso nas aulas de italiano, tinha colegas que cursavam espanhol - os meus melhores amigos tinham escolhido espanhol. E eles me contavam que faziam aulas de literatura, de fonética e fonologia e eu achava 
superinteressante. Assim, comecei a me interessar e a assistir as aulas de espanhol. Eu parei de assistir as aulas de italianos (essas loucuras que a gente faz e, além disso, naquela época as coisas funcionavam diferente). Eu comecei a assistir aulas de espanhol, tanto de língua quanto de literatura. $O$ meu professor de língua estava ensinando fonética e fonologia, pois era a especialidade dele e a pesquisa de sua tese. Então, ele nos ensinava a fazer transcrição fonética. Ele colocava as gravações e tínhamos que transcrevê-las. Ele nos ensinou todos os princípios da fonética e da fonologia: o que é um fonema, um alófono, enfim, todas aquelas coisas que, para mim, eram maravilhosas, eram uma novidade e uma descoberta. Ou seja, eu aprendia coisas novas e não ficava só repetindo palavras, o que era realmente muito chato. Em literatura, imagine, nós já começamos lendo Lorca. Líamos textos assim, como Machado. Líamos, também, poesias e eu gostava muito de poemas. Eu tinha um professor de literatura hispano-americana na época - que depois passou a professor de Semiótica na UNESP - chamado Edvar Lopes que trabalhava muito associando filosofia com a interpretação de textos. Aquilo sim era crescer, era descobrir novas coisas! Então, eu fui me entusiasmando e fui largando o italiano. Isso aconteceu no primeiro ano e, quando chegou ao final desse ano, tentei pedir uma transferência na secretaria - porque, na época era tudo muito mais local, a universidade não era essa máquina enorme, as coisas funcionavam de uma maneira diferente. Então, eu pedi, na secretaria, que queria me transferir e a resposta que veio foi de que eu tinha perdido o prazo da transferência e que teria que ver isso no outro ano. Então, me dei por vencida. Aí, chegou a época de provas e eu, evidentemente, não fiz a prova de espanhol. O professor me procurou inconformado por eu não ter realizado a prova e alegando que eu era sua melhor aluna. Então, eu lhe disse que não tinha feito a prova porque não era sua aluna, que era, na verdade, só ouvinte, pois estava matriculada no italiano e queria passar ao espanhol, mas não me deixaram. Ao ouvir minhas explicações, me pegou pela mão e me levou à secretaria, onde conversou com os funcionários e exigiu que eu fosse transferida, alegando que eu era sua melhor aluna. $O$ catedrático que, na época, era o professor de literatura, também fez um esforço e, como tudo era diferente - não tinha os programas Janus, Fênix, nada dessas coisas, tudo se resolvia de outra forma -, eu consegui, então, a transferência e fiz as provas finais de espanhol.

Quando eu entrei para fazer o francês, eu já tinha estudado essa língua três anos em filosofia, também a tinha estudado desde a admissão no ginásio (durante quatro anos), mais três anos no curso clássico e já estava no sexto ano da Aliança Francesa, tendo concluído o primeiro Nancy. Na faculdade, peguei uma turma que tinha que aprender $\mathrm{Je}$ suis. Então, para mim, o francês também foi um balde de água fria, quero dizer, foi extremamente desanimador. Os professores, em especial o Dudér, fizeram um esforço e me colocaram em outras disciplinas mais adiantadas. Mas faltava algo, aquilo não tinha muita unidade e os grupos eram muito fracos. $O$ que foi também muito desanimador para mim. Ao mesmo tempo, o espanhol era a grande surpresa, a grande novidade, com toda a questão da literatura, da descoberta da cultura que eu desconhecia completamente. Nós tínhamos programas audiovisuais, aulas extras no Instituto de Cultura Hispânica com programas audiovisuais sobre as regiões da Espanha, cidades históricas, monumentos, etc. Eu me lembro que sonhava em conhecer Toledo e Granada. 
Ter entrado em contato com os grandes autores, desde os mais clássicos até os poetas e, sobretudo, com o boom da literatura hispano-americana. Eu peguei quando aquilo explodiu mesmo e nós passamos a estudar García Marques, Cortázar, Onetti, enfim todos aqueles contistas e a presença do fantástico na literatura. Tudo aquilo era fascinante e era uma época de muita repressão política em que coincidiam ditaduras tanto no nosso país quanto em outros países como na Espanha, na Argentina, no Chile. Então, esse contato com a literatura fez eclodir, isto é, fez com que o espanhol aparecesse como uma língua e como um lugar de protesto, de libertação e de resistência. Além disso, havia, também, o folclore latino-americano, com Mercedes Sosa, Violeta Parra, Isella e com todos aqueles cantores e cantautores ou compositores que faziam aquelas músicas que, de alguma forma, falavam de reação, de libertação, do desejo de se libertar desses regimes de força. $E$ tudo isso a gente fazia meio na marginalidade, porque éramos extremamente vigiados, vivíamos uma época de muita repressão. Isso ia criando uma espécie de fascínio e de paixão e me levando a largar o francês. Eu lembro que os meus professores, em especial o catedrático, Albert Audubert, ia na sala dos professores de espanhol e falava que eles estavam roubando sua aluna. Assim, eu fui dedicando-me, cada vez mais, ao espanhol. Eu me lembro de que, no segundo ano de espanhol, quando entreguei um trabalho e o professor foi devolvê-lo ele falou assim: "Você vai trabalhar aqui!", "Você vai ser professora aqui!"’. Então, eu fui ficando e me envolvendo cada vez mais e, de fato, logo que me formei, passei a trabalhar com o espanhol. Trabalhei um pouco com o francês e com o português, mas acabei ficando mesmo com o espanhol e comecei a mergulhar, a estudar e a pesquisar essa língua. Enfim, fui capturada por ela.

\section{P: Muito interessante, professora. Então seria isso mesmo. Eu consegui fazer todas as} perguntas. Muito obrigada.

N: Eu acho que para a minha geração, isso eu acho importante destacar, o espanhol foi esse lugar da rebeldia. Eu gostava muito do francês e era muito boa, falava francês melhor do que o espanhol. Mas, enfim, o espanhol representou o novo, a descoberta inesperada, totalmente inesperada.

P: E essa descoberta se deu na universidade e não naquele ano que você estudou espanhol na escola?

N: Sim, na universidade. Naquele ano em que estudei espanhol na escola eu me saí muito bem, gostei e tive satisfação, não me lembro de ter encarado como algo que estudei forçada ou com algum desconforto, mesmo porque, como eu disse, as aulas eram muito animadas e a gente cantava bastante. Então, estudava mais por isso, mas eu não via ali nada a mais, ou seja, não pensava em ser professora dessa língua ou que o espanhol pudesse servir para algo no futuro. Encarava como um estudo momentâneo. Mas, na universidade veio a descoberta, realmente! $\mathbf{E}$ foi assim, porque no caso do italiano tudo estava muito cristalizado, parado. Acho que foi um momento da então chamada cadeira de italiano, com uma equipe complicada na época. Além disso, eu estava mais madura, pois já tinha feito três anos de filosofia e não queria só ficar em "zoccolo". Então, a possibilidade de estudar coisas novas no espanhol, disciplinas diferentes, ler textos, 
232 entrar em contato com toda a manifestação popular que representava essa liberação foi, 233 para mim, extremamente importante. $\mathrm{E}$, eu acho que isso tudo me capturou!

234 P: Certo, professora Neide. Muito obrigada por sua entrevista.

235 N: Imagine, eu que agradeço. 
Anexo C - Introdução da Gramática de língua espanhola para uso dos brasileiros, de Antenor Nascentes, publicada em 1934.

\section{INTKODUÇẢO}

O espanhol é, como o português, uma lingua de origem Latına.

E' uma lingua sonora, graciosa, falada por quase oilenta mihões de pesscas, na Espanha, nas três Americas e em outros pontos do globo.

$\mathrm{Na}$ Europa, além de falado na Espanha, tambem o é nos Balcans pelos judeus espanhois expulsos da patria no século XV. $\mathrm{Na}$ Africa é falado pelos judeus marroquinos e nos presidios e possessões espanholas (Tanger, Ceuta, Melilla, Rio do Ouro, ilhas Canarias, ilhas de Fernando Pó, Elobey e Ano Bom, Corisco, Guiné Espanhola). $\mathrm{Na}$ America, em todos os países da Sul Amćrica, excepto o nosso Brasil e as Guianas, na América Central, no México, em Cuba, em Porto Rico, em São Domingos, em alguns Estados da União Americana (Arizona, Florida, Texas, Novo Mexico, Baixa California, Colorado). Na Oceania, nas Filipinas, Carolinas e Falaos.

Estando o Brasil cercado de paises onde se fala - espanhol e com os quais se acha em relações constantes, de ordem politica, comercial, etc. é de grande vantagem para os brasileiros o conhecimento não perfunctório daquela lingua, assim como o da lingua portuguesa o é para os naturais de outros paises da América do Sul. E tanto assim o compreendeu o govêrno do Uruguai que criou uma cadeira de português, em reciprocidade da qual a lei n. 3.674 de 7 de Janeiro de 1919 criou uma cadeira de espanhol no Colégio Pedro II, extinta pela reforma do ensino de 1925. Diga-se de passagem que na Espanha há provincias onde o povo não fala espanhol; na Galicia, fala-se 
- galego, co-dialecto do português, nas Provincias Bascas fala-se o vasconço, na Catalunha, Valença, nas Baleares falam-se o catalão e suas variantes; o espanhol, todavia, é a lingua oficial de todo o reino.

O espanhol é parecidissimo com o português, como tóda a gente o sabe. Quem cunhece o português, com facilidade lê $\epsilon$ compreende o espanisol, sentirá, é verdade, algumas deficiências. Além disso é uma lingua familiar a nós por causa da imigração espanhola em nosso país, das companhias dramaticas, de operetas e zarzuelas que anualmente nos visitam, das relações com as republicas vizinhas.

A extrema semelhança das duas linguas, entretanto (parece até um paradoxo), é a maior dificuldade que encontramos, pois quando mal pensamos que uma palavra, uma locução, ou uma forma, se encontra em ambas as linguas, defrontamos profunda diferença.

Daí a necessidade de precisarmos fixar especialmente o que há de diferente nas duas linguas; foi êsse o nosso escopb.

O espanhol é talvez a lingua mais disciplinada que haja. Filipe V em 1713 fundou uma academia da lingua, a qual, entre outros encargos, recebeu o de elaborar uma gramática e um dicionário. O dicionário apareceu em 1726 e está hoje na 15.` edição; a gramática surgiu em 1771, sendo de 1917 a última edição.

Em matéria de ortografia, prosódia, morfologia, purismo de linguagem, vernaculidade, a autoridade soberana da Academia é obedecida sem discrepância; por isso a citamos sempre que queremos afastar contestações.

Uma lei de 9 .de Setembro de 1857 declarou a gramática da Academia o texto unico e obrigatorio das escolas de ensino público. 


\section{$-5-$}

A lingua espanhola também se chama castelhana, porque, "havendo Castela, diz a Academia, contribuido de modo preponderante na formação da nação espanhola, logrou que sua própria língua prevalecesse sôbre os dialectos afins que se falam nos antigos reinos de Leão, Aragão e Navarra, e fez que se propagasse pela conquista à Andaluzia, à Murcia e à Extremadura".

Desta denominação de castelhana hà exemplos desde o século XIII; alguns autores clássicos e gramáticos repeliram-na por inexacta (PIDAL). Não obstante, a Academia, embora empregue ambas, a prefere.

No estrangeiro foi sempre geral a denominação de espanhola (PIDAL) e a razão é facil : no estrangeiro apagam-se as divergéncias dialectais para só considerar a lingua da Espanha. Eis porque, a exemplo de muitos autores, denominámos nosso livro "Gramática Espanhola" e não "Gramática Castelhana", como talvez quisessem os zoilos, embora tratemos especialmente do castelhano e só acidentalmente nos ocupemos com os dialectos. 
Anexo D - Programa do livro didático Español básico/ Curso clássico e científico, de José Ramón Calleja Álvarez, publicado em 1953.

\author{
P R O G R A M A \\ CURSOS CLÁSSICO E CIENTÍFICO

\section{I - Leitura:}

1. De trechos modernos, em prosa e em verso, que tenham por assunto principal as tradições, a arte e a paisagem na Espanha e Hispano-América.

2. De excertos dos maiores escritores espanhóis e hispanoamericanos, de forma que fiquem conhecidas as mais importantes obras e as características gerais das literaturas de língua espanhola.

3. Deverá dar-se ao aluno ùm vocabulário sôbre: fórmulas de cortesia; a família; dias da semana, meses, o tempo, as estações e as horas; as côres e as dimensões; as partes do corpo humano e as posições; os sentidos; o vestuário; os alimentos e as refeições; animais e plantas mais importantes; ofícios e profissỏes; a indústria e o comércio; os meios de transporte; a casa, a cidade e a vida urbana; o campo, a agricultura e a vida campestre; vida social, escolar, doméstica e cívica; desportos e diversões.

\title{
II - Gramática:
}

1. Alfabeto, ditongos, tritongos, hiatos, seseo, yeismo;

2. Acentuação;

3. Artigos, substantivos, adjetivos, pronomes e numerais;

4. Flexões de número, gênero e grau;

5. Verbo: pessoas, números, tempos e modos. Vozes. Verbos auxíliares haber e ser. Verbos regulares e irregulares.

6. Palavras invariáveis;

7. Prefixos e sufixos;

8. Principais regras de concordância;

9. Regência;

10. Idiotismos. 
Merecerão especial atenção, porque causa de êrros freqüentes: o valor do $h$; a pronúncia do $j$ : a emissão de $e, o, e, l$, finais; o artigo neutro; o artigo masculino usado, por eufonia, diante de substantivos femininos; o gênero ambíguo; os plurais em ces; os c.djetivos que se apocopam; os verbos irregulares de $1 .^{\mathrm{a}}$ e 2.a classe; o verbo de usted; o acento diacrítico. Serão objetos de especial estudo os heteroprosódicos, heterossemânticos, heterogenéricos, heterográficós e biléxicos, em relação ao português.

\section{III - Exercicios}

Além da leitura e dos exercícios gramaticais haverá:

1. Exercícios de ortografia e ortofonia.

2. Exercícios para a ampliação do vocabulário.

3. Exercícios de tradução e versão.

4. Conversação, exposições orais, reproduções livres dos excertos literários lidos, salientando-se a importância da obra, época e meio em que foi produzida e dando-se uma notícia sôbre o respectivo autor.

5. Exercícios de redação e composição. 
Anexo E - Introdução do livro didático Curso Práctico de Español, de Francisco Frigério, publicado em 1977.

Las aportaciones del Profesor D. Francisco Frigério a la didactica de la Lengua espanola.

Quisiéramos rendir en estos comentarios el justo tributo de alabanza y estimación que merecen las aportaciones que ha consagrado a la didáctica de la Lengua española, el docto profesor brasileño D. Francisco Frigério, nuestro muy caro amigo y distin guido colega, con ${ }^{\text {s }}$ sus obras: Curso Práctico de Español. Curitiba Paranā. 1971 (del que ya se han hechotres ediciones) y Audiovisual Español Estructural. I y II.

La suma de aciertos que el más somero examen descubre en las citadas obras, se debe a que en su autor se dan estas varias y relevantes circunstancias: una apasionada vocación por los estudios filológicos; una seria formación de los mismos, perfeccio nada al más alto nivel en el curso de Filología Románica de 1áa Facultad de Filosofía y Letras de la Universidad de Salamanca, y en los cursos para extranjeros de la Universidad Internacional. "Menéndez Pelayo" de Santander, y en el Centro de Cultura Hispänica de Madrid; un continuado ejercicio docente en los importantes Centros en que profesa la enseñanza del Españo1: Colegio Estatal de Parana y Colegio del Sagrado Corazón de Jesüs. Y, final mente, una vigilante atención para conformar la enseñanza de 1a Lengua casteliana con los más luminosos criterios y los más mo-0 dernos procedimientos pedagógicos, entre los que alcanza marcado relieve el método audiovisual:。

Gozan los libros escritos por el profesor Frigério, para la enseñanza del español, del privilegio que supone el que los alum nos que van a manejarios, y sobre los que ha de ejercerse la 1 a bor profesoral, parten de una lengua hermana, y de una estructura anāloga a aquélla cuyo aprendizaje emprenden.

En efecto, la gran cercanía y parentesco entre ambas lenguas romānicas: el portugués y el español, permite a los alumnos brasileños seguir en el estudio de éste, casi el mismo camino utilizado en el conocimiento y adquisición. de la lengua materna. Y ese método no puede ser otro que el que hoy se emplea con el nayor rendimiento y eficacia: partir de la realidad viva y direc ta de la lengua, y procurar que el aluno consiga el mayor numeró posible de recursos expresivos. Esta finalidad, de carácter esen cialmente práctico, priva actualmente en las primeras etapas de la enseñanza lingüística, sobre el conocimiento teórico, gramatical, abstracto.

De èsté, sin embargo, no podrā ni deberá prescindirse con tal que se ofrezca en perfecto ajuste y graduación con 1 a edad $y$ con las vivencias idiomáticas que haya alcanzado el hablante. De otro modo, resultaría ineficaz por anticipado e inmaturo.Los con ceptos y nociones gramaticales han de contemplarse, mientras $1 \bar{a}$ capacidad de abstración no adquiera el debido desarrollo, en fun cion de los textos que se lean y estudien, educidos de los mismos y tomándoles siempre como punto de referencia. (1)

Así lo cumple a maravilla, el profesor Frigério en su Curso Präctico de Español. Usa en él nuestro prestigioso colega de los

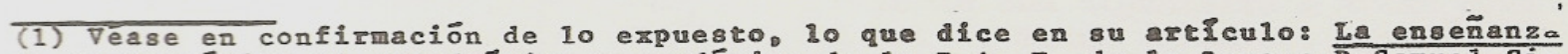
de la Gramática el catedratico y académico de la R.A. E. de Ia Lengua D.Samuel Gí li Gaya, Revista de Educación no 21952, págs 119-192. 
medios mäs eficientes para crear el häbito de expresiōn en castellano: conversaciones; extensos vocabularios; 1 ecturas perfectamente elegidas de escritores españoles e hispanoamericanos, pa ra que de ellas puedan educirse las distintas nociones gramatica les al par que eduquen el gusto literario de los alumnos; bellas ilustraciones en armonia con los textos, a fin de que resulten mäs sugestivos y aviven la capacidad intuitiva de aquéllos; gran riqueza de modismos, refranes, proverbios y hasta adivinanzas tan abundantes en castellano: fórmulas de cortesia y de expresion de muy variados sentimientos.

Con especial cuidado busca el autor facilitar a sus alumnos brasileños el aprendizaje de la lengua castellana, resaltando el paralelismo que existe en la estructura general, en el vocabula rio, en la morfología, régimen y construcción entre la lengua me terna y la de Cervantes, sin dejar de anotar con precision 1a divergencias que entre ellas se advierten. Para la mayor efica cia de este cotejo, se propone con frecuencia una práctica utili sima: la versión de párrafos castellanos al portugués y vicever= sa.

Al final del 1ibro, un amplio apéndice gramatical recoge en forma sistemática, sencilla y con gran rigor cientifico, los paradigmas y las nociones gramaticales que no han sido anotadas a través de los textos, y son necesarias para el uso correcto del castellano.

En suma: el tratado Curso Práctico de Español del profesor Frigério, cumple perfectamente conel precepto horaciano de enseñar deleitando.

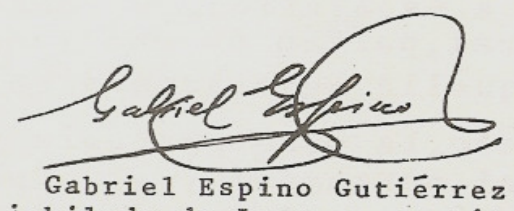

Catedrático jubilado de Lengua y Literatura española del Instituto Nacional "Fr.Luis de León", de Salamanca. 
Anexo F - Presentación da coleção didática Vamos a Hablar, de Felipe B. Pedraza Jiménez e Milagros Rodríguez Cáceres, publicada em 1992.

\section{Presentación}

Vamos a hablar es un método de español creado para atender las peculiares necesidades de los alumnos lusoparlantes y, en especial, de los brasileños. Hemos tratado de aprovechar las facilidades que nos ofrece la semejanza de las dos lenguas y de esquivar los escollos que encierra esa misma cercanía. El ritmo es, como parece lógico, el que exige un alumnado que puede avanzar con rapidez en el dominio del nuevo idioma. Pero paralelamente a la progresión viva y dinámica, Vamos a habiar insiste en la necesidad de un esfuerzo especial para asimilar desde el primer momento las construcciones más genuinas y propias del español, la pronunciación más exacta y las locuciones más naturales y expresivas.

Por eso cada lección va a combinar propuestas didácticas diversas y complementarias. Nuestro método quiere ser una invitación a que el alumno se exprese, intervenga en clase, converse con sus compañeros e incluso discuta apasionadamente... en español. Junto a esta faceta y para evitar que se derive inconscientemente hacia una jerga informe (el portuñol), insistimos desde el principio en algunas cliestiones fonéticas, morfosintácticas y léxicas fundamentales, que perfilan con cláridad los rasgos de la lengua española. Las técnicas comunicativas deben aliarse a las propuestas de carácter estructural para conseguir una mayor eficacia en el proceso de aprendizaje; de la misma forma que la expresión oral, prioritaria en todos los casos, se enriquece y afianza con ejercicios escritos adecuadamente dosificados.

El método que el lector tiene entre las manos se creó, a instancias de D. José Manuel Bolado Somolinos, Consejero de Educación de la Embajada de España, para los cursos de español del Círculo Cultural Miguel de Cervantes. Durante dos años lo hemos experimentado y corregido a la vista de los resultados obtenidos en clase. Es para nosotros un gustoso deber dar las gracias a los alumnos que con su comprensión y cariño nos han permitido depurar y perfeccionar este método. También queremos manifestar nuestro agradecimiento a cuantas personas nos han ayudado en la preparación de los materiales que ahora presentamos. Gracias a Chony, Mavi e Izildinha, que cuidaron primorosamente de las primeras "ediciones" experimentales; a Eladio Sebastián Herrero, que ilustró los esbozos de esta obra; a Maria Salete Bento Cicaroni, que se ha desvivido para que estos-volúmenes-vean la luz; a Sandra y al personal de Editora Ática, que se han ocupado eficazmente de todo el proceso de edición. A todos, nuestro reconocimiento y gratitud.

Los autores 


\section{PARTE B}

Anexo G - Apresentação da primeira edição da coleção didática Español sin Fronteras, de María de Los Ángeles J. García e Josephine Sánchez Hernández, publicada em 1996.

\section{Apresentação}

O processo de aprendizado de uma língua pode e deve estar ligado ao prazer - prazer da descoberta pelo aluno e prazer do professor em alcançar seu objetivo. Recordamos hoje nossa dificuldade como professoras, anos atrás. Embora o espanhol fosse para nós a "primeira língua materna", nos sentíamos desamparadas pela falta de material adequado ao ensino deste idioma para alunos brasileiros. Naquela época, não havia muitas obras disponíveis, e as poucas existentes eram estrangeiras ou escritas por estrangeiros, que não dispunham do necessário conhecimento de português para avaliar as dificuldades do aluno brasileiro em relação ao aprendizado da língua espanhola.

Decidimos então criar nosso próprio material, aproveitando tudo que chegava em nossas mãos: contos, poesias, letras de músicas, artigos de jornais ou de revistas, etc. Assim, de maneira lúdica e descontraída, conseguíamos alcançar nosso objetivo, ou seja, levar o aluno a se interessar pela língua espanhola. Foi a partir de então que nos ocorreu a idéia de escrever uma obra didática de Espanhol, um material que atendesse às necessidades de nossos alunos e, principalmente, servisse de apoio para o professor.

Hoje, existem vários e bons livros no mercado, mas queremos deixar nossa contribuição - pelo amor que temos a esta língua e porque acreditamos nos frutos deste trabalho.

Vale lembrar que o professor é e continuará sendo o melhor material em sala de aula. Com o apoio deste método, ele terá liberdade para criar e recriar com seus alunos, transformando suas aulas em um exercício estimulante.

Aprender una lengua es abrir una puerta y descubrir muchos mundos. iEnhorabuena! Español sin fronteras. 
Anexo H - Capas dos quatro volumes da primeira edição da coleção didática Español sin Fronteras, publicada por María de Los Ángeles J. García e Josephine Sánchez Hernández, em 1996.
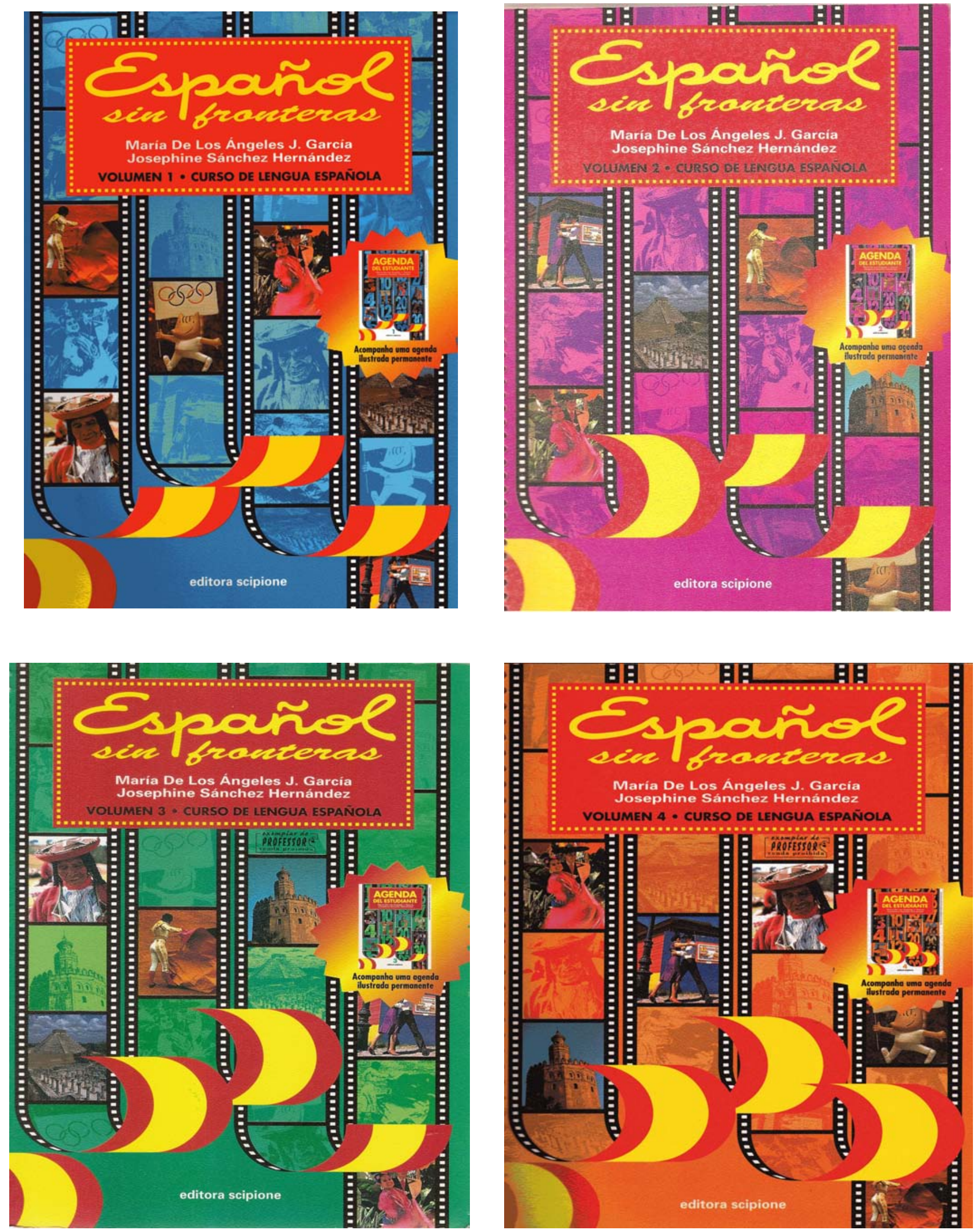
Anexo I - Apresentação da segunda edição da coleção didática Español sin Fronteras, de María de Los Ángeles J. García e Josephine Sánchez Hernández, publicada em 2002.

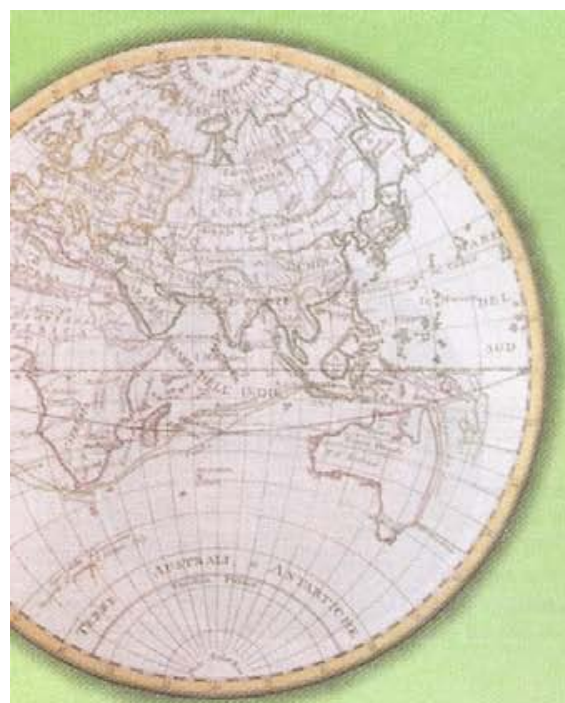

"Yo tengo tantos bermanos

Que no los puedo contar En el valle, la montaña, En la pampa y en el mar. Cada cual con sus trabajos Con sus sueños cada cual Con la esperanza adelante, Con los recuerdos detrás. Yo tengo tantos bermanos Que no los puedo contar." "Los bermanos", Atabualpa Yupanqui "Los bermanos", Atabualpa Yupanqui

\section{Presentación}

Aprender una lengua es abrir una puerta y descubrir muchos mundos - mundos sin fronteras, que nos hermanan y nos enriquecen con su diversidad cultural.

Por el amor que tenemos a esta lengua y porque, una vez más, creemos en el fruto de este trabajo, te invitamos a hacer un recorrido con Español sin fronteras y a abrir puertas que te llevarán a un mundo de ideas, a conocer culturas, a la diversión, a la modernidad, a la reflexión y al crecimiento interior.

Toda evolución se da a través del aprendizaje. del acierto y del propio error. "Somos lo que hacemos, pero somos, principalmente, lo que hacemos para cambiar lo que somos." Eduardo Galeano.

Que el aprendizaje siempre esté relacionado al placer - placer del descubrimiento por el alumno y placer del profesor en alcanzar su meta. 
Anexo J - Capas dos quatro volumes da segunda edição da coleção didática Español sin

Fronteras, publicada por María de Los Ángeles J. García e Josephine Sánchez Hernández, em 2002.
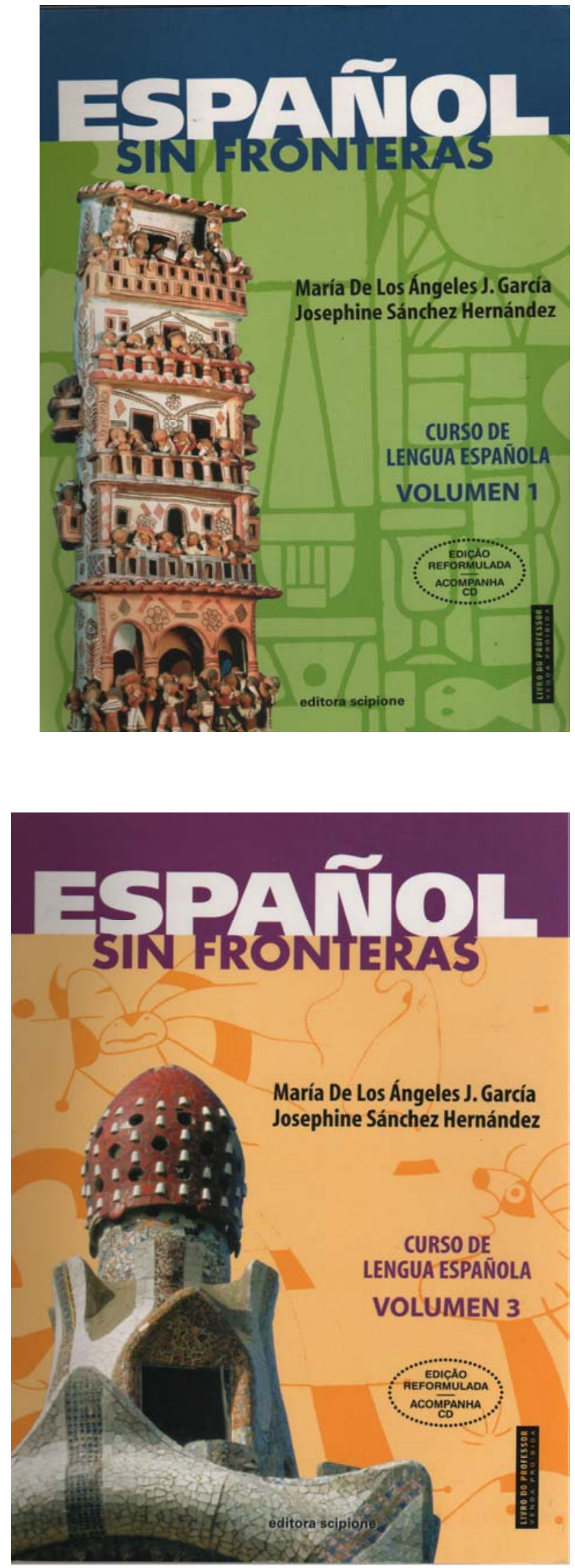
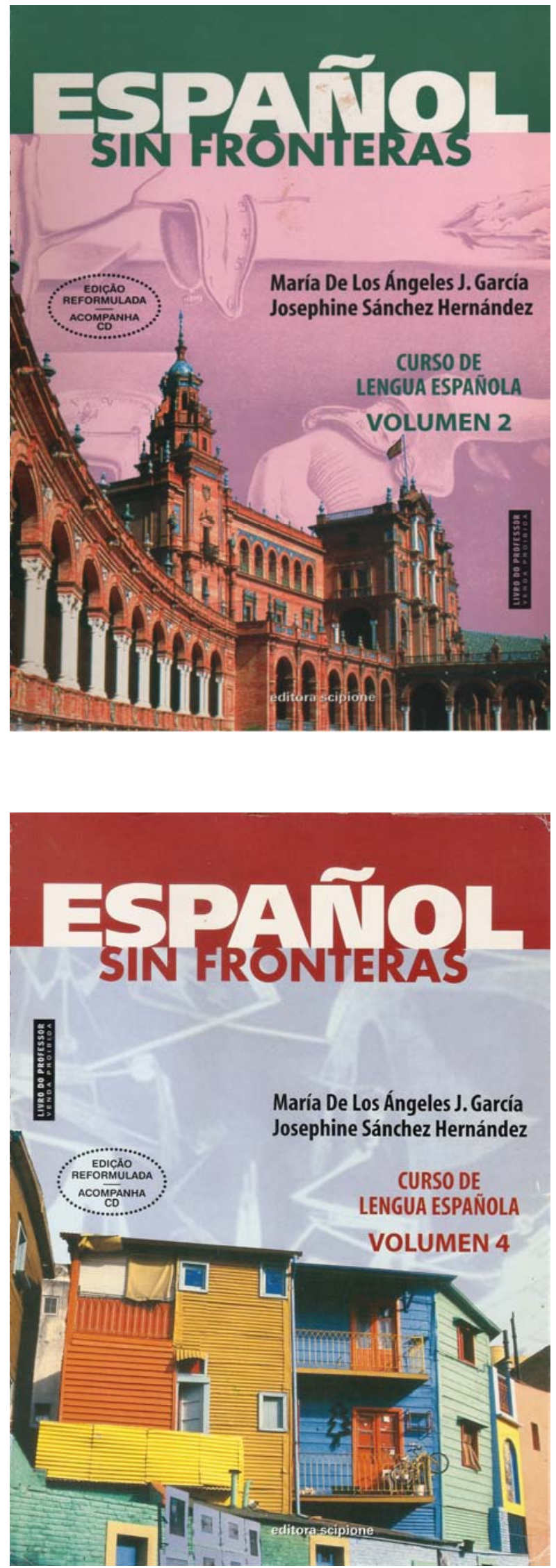
Anexo K- Letra da canção "Los hermanos", de Atahualpa Yupanqui. (Disponível em: $<$ http://www.cancioneros.com/nc/4317/0/los-hermanos-atahualpa-yupanqui> Acesso em: 09/03/2011).

\section{Los hermanos (Atahualpa Yupanqui)}

Yo tengo tantos hermanos, que no los puedo contar, en el valle, la montaña, en la pampa y en el mar.

Cada cual con sus trabajos, con sus sueños cada cual, con la esperanza delante, con los recuerdos, detrás.

Yo tengo tantos hermanos, que no los puedo contar.

Gente de mano caliente por eso de la amistad, con un rezo pa' rezarlo, con un llanto pa' llorar.

Con un horizonte abierto, que siempre está más allá, y esa fuerza pa' buscarlo con tesón y voluntad.

Cuando parece más cerca es cuando se aleja más. Yo tengo tantos hermanos, que no los puedo contar.

Y así seguimos andando curtidos de soledad, nos perdemos por el mundo, nos volvemos a encontrar.
Y así nos reconocemos por el lejano mirar, por las coplas que mordemos, semillas de inmensidad.

Y así seguimos andando curtidos de soledad, $\mathrm{y}$ en nosotros nuestros muertos pa' que naide quede atrás.

Yo tengo tantos hermanos, que no los puedo contar, y una novia muy hermosa que se llama libertad. 
Anexo L - Presentación da terceira edição da coleção didática Español sin Fronteras, de María de Los Ángeles J. García e Josephine Sánchez Hernández, publicada em 2007.

\section{Presentación}

\section{¡Hola!}

\section{Queridos alumnos,}

Cuando aprendemos un nuevo idioma, abrimos una puerta que da paso a una nueva cultura, a las particularidades de vida de otros pueblos. No se aprende una nueva lengua sólo por el valor del idioma en sí mismo, pero para ampliar nuestra participación en un mundo cada vez más amplio y complejo.

Español sin fronteras, desde su primera edición, fue elaborado con este propósito: facilitar tu acceso a un universo cada vez más amplio, para poder participar en él con éxito. Es una colección pensada para ti que quieres aprender español de una forma agradable y divertida. En esta nueva edición, hemos introducido nuevas secciones con textos interesantes y llenos de curiosidades, hemos elaborado ejercicios más contextualizados, hemos buscado, en fin, ofrecerte un curso más moderno y atractivo, fundamentado en un abordaje comunicativo. Sin embargo hemos buscado mantener la metodología adoptada en las ediciones anteriores, por haberse revelado útil a todos los estudiantes que se han servido de ella hasta el presente momento. Pero sabemos que no basta el libro, será necesario, principalmente, tu empeño, sin el cual todo tu esfuerzo habrá sido inútil. Al fin de cuentas, tú serás el principal agente de tu aprendizaje para que puedas dominar plenamente el español. No consideres el estudio como una obligación sino como una oportunidad para entrar en el mundo del conocimiento y del saber.

Si entiendes, lees, hablas y escribes en español, podrás comunicarte con casi 500 millones de personas que también hablan el español. Esto significa que contarás con un gran abanico de posibilidades que te abrirán puertas y te llevarán a descubrir otras culturas, sin fronteras...

\section{¡Mucho éxito!}


Anexo M - Capas dos quatro volumes da terceira edição da coleção didática Español sin Fronteras, publicada por María de Los Ángeles J. García e Josephine Sánchez Hernández, em 2007.
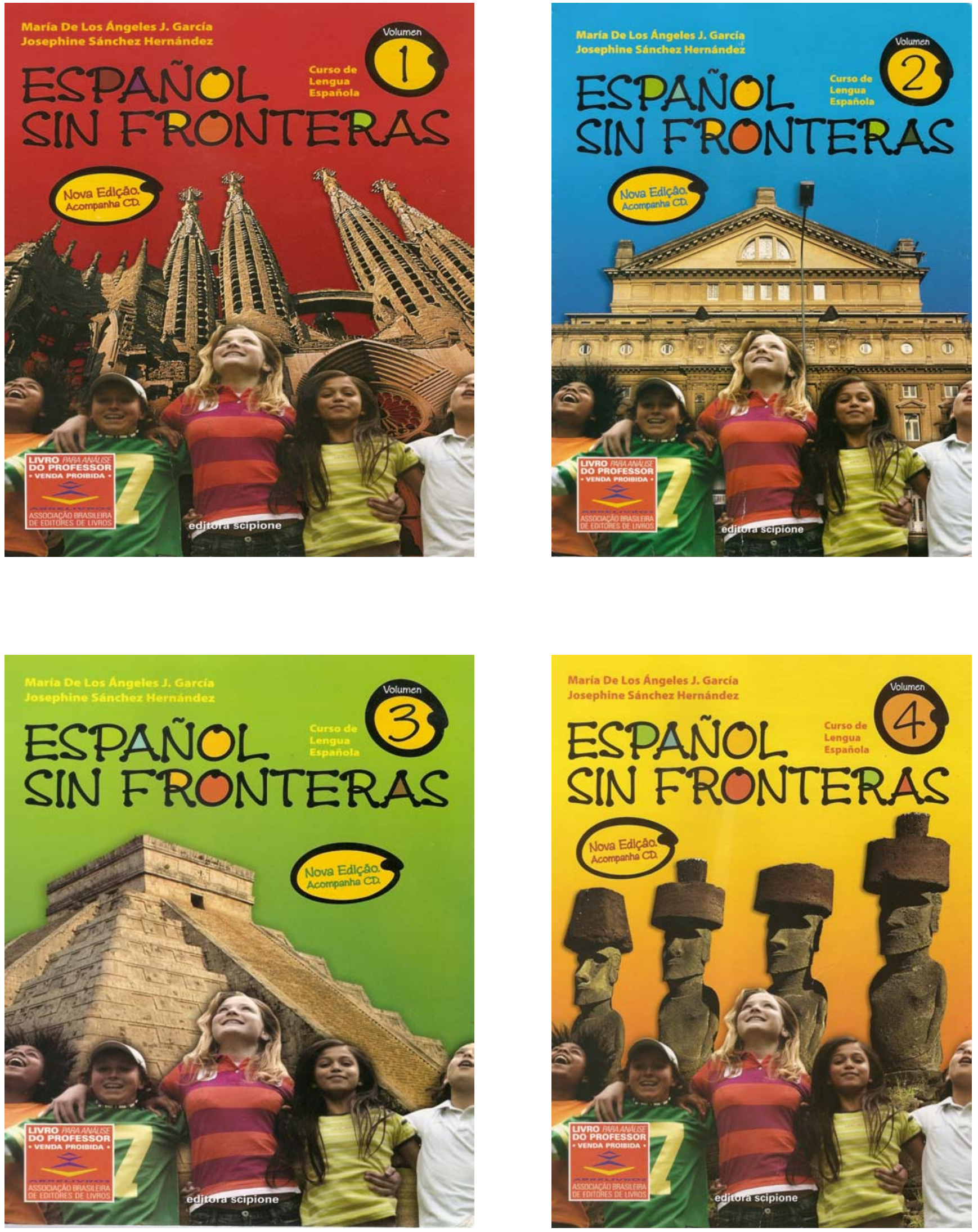